\title{
The Language Question under Napoleon
}

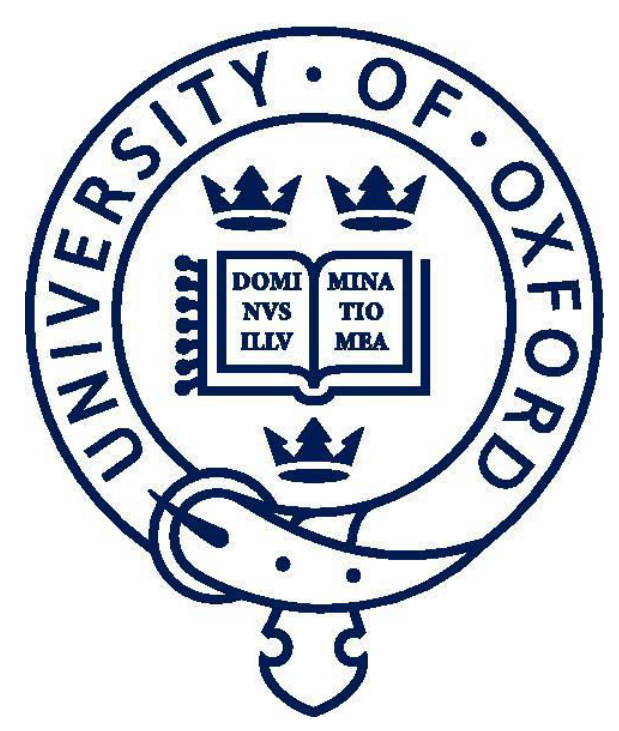

Stewart McCain, Worcester College, Faculty of History, Oxford

Thesis submitted for the degree of Doctor of Philosophy, Michaelmas term, 2014 


\section{Acknowledgements}

The research for this thesis was completed with the aid of a doctoral studentship from the Arts and Humanities Research Council. I was also fortunate enough to receive the P.J. Marshall fellowship from the Royal Historical Society. It was Professor Marshall's support for doctoral students in their fourth year of study that made the completion of this thesis possible, and I would like to extend my heartfelt thanks to him for his generosity. Over the past four years I have also benefitted from a number of small research grants, from the Society for the Study of French History, from the Arnold, Bryce and Reed fund at the History Faculty in Oxford, and from Worcester College, which have allowed me to complete research trips to France. Another grant from the Society for the Study of French History also allowed me to present material from the thesis at the 2014 annual conference of the Society for French Historical Studies in Montreal, while the exchange programme between the History Faculty at Oxford and the École Normale Supérieure de Cachan provided me with a Parisian base from which to explore the archives of the capital.

I owe a debt of gratitude to Professor Micheal Broers and Dr David Hopkin for their support and insight over the past four years. I could not have wished for more knowledgeable and engaged supervisors and their support and input has been greatly appreciated. As the reader will observe, the work of both has shaped my approach to the period in quite fundamental ways. Thanks are also due to Christina de Bellaigue, Oliver Zimmer, Robert Evans and Laurence Brockliss at the Faculty of History in Oxford, all of whom have provided insightful feedback on parts of the thesis. I am similarly grateful to attendees of the Long Nineteenth Century research seminar in Oxford, which has provided a stimulated forum for academic debate during my time as a doctoral student. I also thank Stéphane Gerson, for his invaluable commentary on parts of the thesis, while Alan Forrest, David Bell, Rafe Blaufarb, Malcolm Crook, Colin Jones, Munro Price, Tom Stammers, and William Pooley have all provided useful suggestions or friendly faces in the archives. Whatever defects remain persist despite their good offices.

Finally, I would like to thank all those who have provided support, both material and moral, but especially my parents and Stephanie Brand, whose patience and encouragement has far exceeded the bounds of what could be reasonably expected. 


\section{Abstract: The Language Question under Napoleon}

From the campaign waged by Revolutionaries like Barère and the Abbé Grégoire against those regional languages they referred to pejoratively as 'patois', to the educational policies of Jules Ferry a century later, successive governments of France engaged in a broadly successful struggle to force the French to speak French. Inverting the logic of cultural nationalists like Herder, who claimed a shared language as the legitimate basis of national polities, French legislators sought to impose French as a common language on a linguistically diverse population that had already been constituted as a state. Recent historical work has shown the particular significance of such projects during the Napoleonic period. Historians have begun considering how far the Napoleonic regime was characterized by cultural imperialism. While the ideological nature of such projects- the 'view from the centre', so to speak- is now well understood by historians, this thesis is concerned with the practice of Napoleonic imperialism in one sphere of action: language. By focusing on the practice of linguistic imperialism under Napoleon this thesis makes an important contribution to understandings of the cultural politics of the period as well as Napoleonic state-building policies more generally.

This thesis is about the relation between language, identity and state formation in France and the French Empire during the Napoleonic period. It is about the efforts of the Napoleonic state to impose cultural homogeneity on the culturally diverse populations within its borders. It is also, and centrally, about how these populations, or at least those members of the population who engaged with the Napoleonic state, navigated the linguistic demands of the centre. In doing so it broaches two apparently distinct, but in reality closely related areas of historical enquiry- the relationship between Napoleonic imperialism and nationalist revival in Europe, and the process of integration and assimilation of the culturally and linguistically diverse populations of France.

The most important original contribution of the thesis is that it seeks to go beyond ideologies of cultural imperialism. It is not just about the struggle to impose cultural and linguistic hegemony. Rather, it is about the linguistic strategies pursued by actors during a period when they faced increasing pressures towards linguistic conformity. The central argument of the thesis is that individuals faced a series of choices on a spectrum between the valorisation of local language against centralising pressures, or conformity in pursuit of social status and Parisian approval. Not only did actors select different strategies depending on the local social context, they often made different, even apparently contradictory, linguistic moves in different circumstances. The thesis will therefore concentrate on the elaboration of local knowledge, on the arguments about linguistic practice raised within Napoleonic institutions. It will reveal a dynamic process of negotiation between centre and periphery. While efforts to 'franciser' the population were buttressed by a discourse of modernization and social improvement, state agents on the periphery developed a sense of linguistic diversity variously as an intractable feature of society, as a feature of local patrimony and even as the 'mother tongue', something integral to the sense of self of those who spoke it.

The study is divided broadly into two sections. In the first section, I discuss the classificatory systems available to speakers and the discursive options available to them within different contexts. The attitudes of speakers is examined primarily through the production of ethnographic data of the type the regime was famed for; the descriptive statistics orchestrated by the Bureau de la statistique and drafted in the departments by prefects, administrators and local scholars. The first chapter is 
concerned with the production of knowledge about society during the Revolutionary and Napoleonic period, specifically with the tradition of descriptive statistics that emerged during the period. The administrative gaze of the officials who authored these descriptions of the territories and populations they governed served to construct social and cultural practice, including language, as an object of state action. The intention was to create a synchronic picture of society at the start of the new regime which would serve to illustrate the social progress engendered by the actions of the state.

These departmental statistics frequently cited language as an object of reform, and with the enquiry into the languages of the Empire, conducted between 1806 and 1812 by the head of the Bureau de la statistique Charles-Etienne Coquebert de Montbret, and his son Etienne, who was also an official at the Bureau, language was placed firmly under the administrative gaze. This enquiry, which emerged from the tradition of descriptive statistics, revealed the tensions implicit in the production of social knowledge. The descriptive statistics were drafted or overseen by prefects, who drew on knowledge they gleaned from their own correspondence with local administrators and tours of the department. The enquiry carried out by the Coqueberts, in contrast, preserves a series of direct exchanges between the centre and the kinds of local state notables described above from which telling divergences in the classification and status of local knowledge forms like language emerge.

The next chapter, on the material generated by the Coqueberts focuses on divergent visions of the relationship between language and space. It is argued that while the Coqueberts sought to understand linguistic diversity in terms of territory and space, their correspondents tended to associate different styles of speaking with place, reflecting how firmly rooted in the local the social imaginary of these figures was. This in turn reveals an important distinction between types of geographical knowledge. On the one hand, administrators such as the Coqueberts were focused on territory, on geographical space as it is administered by the state. In contrast to this, many of their correspondents thought in terms of a situated sense of place, of geography as something experienced and lived through the interactions of local communities. It is argued that, rather than understanding linguistic difference in relation to the proto-philological distinctions of linguistic territory drawn by the Coqueberts, they viewed language through the prism of local rivalries.

The following chapter concerns the social use of dialects, demonstrating that diglossia was a central feature of linguistic practice, transcending both the linguistic boundaries between the Langues d'oc and the Langues d'oil fetishized by the Coqueberts, and the political boundaries of prerevolutionary France. However, the diglossic situation revealed by the work of the Coqueberts, substantiated by the work of later folklorists, demonstrates how the value of French as an ' $\mathrm{H}$ ' language was not confined to the political structures of the French state, but grounded in the everyday linguistic practice of communities.

Having shown the diglossic practices that pertained across much of France, the final chapter on the Coqueberts' enquiry is concerned with the attitudes of contemporaries towards their own linguistic diversity. Focusing on how local notables, themselves often bilingual, understood their own linguistic diversity and sought to represent it to the centre reveals not only the stigma that could be attached to speakers of local dialects, but the effort to construct the local language as linguistic 
patrimony, as a form of local knowledge in which, as native speakers, those writing to the Coqueberts might be considered experts.

In the second half of this thesis I focus on how the nature of the linguistic diversity of the French population, as well as the attitudes of local notables towards language influenced the elaboration of linguistic practice within three crucial social institutions- the school, the law court and the Church. In all three of these institutions, the dynamic between local and official forms of knowledge, outlined in the first half of the study, becomes centred on the question of how far practice should accommodate local culture, or conversely seek to impose homogeneity on local communities. An examination of school inspector reports from the Napoleonic period shows how, in keeping with educational projects elaborated during the Revolution, the schoolroom was considered a crucial site for the dissemination of the national language. However, a detailed examination of the primary schooling in the Alpes-Maritimes shows how, despite the efforts of the prefect, French was not always able to dominate Italian in the classrooms of the department. This was not simply a case of the local trumping the centre. Rather, as the distribution of linguistic practice in the primary schools of the department shows, the crucial factor was the position of French or Italian as the $\mathrm{H}$ form, in which local elites and schoolteachers had invested and to which they consequently remained loyal.

At the start of the Napoleonic period, the law courts of the empire, the focus of the next chapter, were similarly understood as a mechanism for the standardisation and homogenization of society. The Napoleonic Empire retained a commitment to legal universalism, and as such a common legal procedure, carried out in a common language, was deemed both central to the Napoleonic project and a means by which local legal officials might be encouraged to learn French. However, as demonstrated by the recruitment of judges and the testimony of legal officials themselves, this aim was often in conflict with the effective administration of justice. As a result, informal accommodations, and eventually official provisions, for the use of other languages were introduced.

The Church, the subject of the final chapter of the thesis, is generally understood as an opponent of centralising and modernizing projects, cleaving to traditional cultural forms and local languages as a means to insulate the population from secularizing trends. However, an examination of the Church during the Napoleonic period reveals an institution riven by exactly the same uncertainties and debates as the education and legal systems. While commentators focusing on the Third Republic have understood the Church as an essentially reactionary force, an impulse towards the regulation of cultural practice, particularly of popular religious forms, had long influenced pastoral work. The linguistic character of religious practice across France was a patchwork, in some places making use of the national language for worship alongside Latin while regional languages dominated in others. However, the tendency of the Church hierarchy towards social pedagogy is revealed in the seminary regulations of the Napoleonic period, which invariably sought to familiarise the next generation of priests with French. It was only with the fall of Napoleon and the reChristianisation campaigns under the restored Bourbon monarchy that the 'mother tongue' came to be understood as a means of saving souls, and only then within the frequently controversial circles of missionaries.

The striking thing about these arguments over linguistic practice is the way in which local officials mobilized notions of linguistic and cultural particularism to justify departures from what 
otherwise might be considered desirable by the regime. The normative orientation, the position taking, of the local notability in relation to linguistic diversity had a discernible impact on the linguistic forms of the state. The central problem here is to historicize the rhetoric of modernization that emerges from the source material, to understand modernity not as a check-list of conditions that arise through an often unspecified historical process, but, much as with state power, as a conscious mind-set or set of choices, as a normative orientation to the features of social life. Modernity, it is argued, is a heterogeneous and ambivalent experience, and one which sees social practices constituted and legitimized as 'traditions' and 'heritages' as frequently as they are denounced, restricted or reformed. 


\section{Contents}

Abbreviations

Introduction: Language, Empire and the New Regime

1 Language under the Administrative Gaze: State, Statistics and Social Knowledge under Napoleon

2 Visions of Linguistic Space: The Coqueberts de Montbret and the Languages of the French Empire

3 'Le Nom Ignoble de Patois'- Cultivated Language and the Speech of the People

4 Francisation and Linguistic Patrimony: Language, State and Local Knowledge under Napoleon

5 Education, the State and Linguistic Imperialism in Nineteenth Century France

Page 152

6 Language, Law and the Legal Profession: Negotiating Cultural Identity in an Imperial Institution

7 Organised Religion, Language and the French State from Ancien Régime to Napoleon

Conclusion

Appendices

Bibliogrpahy 
Tables

Table 1: Population of the First French Empire by Language

Page 63

Table 2: Translators of the Parable by Occupation

Page 68

Table 3: Alpes-Maritimes- Teachers by Languages Taught, Thermidor-Fructidor year XI (July-August 1803)

Page165

Table 4: Alpes-Maritimes- Teachers by Languages Taught, 1809

Page170

Table 5- Judges in the resort of the court of appeal of Genoa by origin

Page223

Table 6- Judges in the jurisdiction of the court of appeal of Trier by origin

Page223

Table 7- Francophone judges in the jurisdiction of the appeal court of Genoa by origin

Page224

Table 8- Francophone judges in the jurisdiction of the appeal court of Trier by origin

Page224

Table 9 - Population of the towns of Colmar, Mulhouse, Ribeauvillé and Ste Marie aux Mines by Religious Confession, 1817 
Appendices

Figure 1: Language in the Statistiques départementales (an VII- 1813)

Page 292

Figure 2 : No. of Statistiques départementales Containing information on Language by Year

Figure 3 : No. of Statistiques départementales Without information on Language by Year

Page 293

Figure 4: Translators of the Parable by Occupation

Page 294

Figure 5: Eugène Coquebert de Montbret's Typology of Languages of the French Empire

Page 295

Figure 6: Linguistic Geography of the Napoleonic Empire

Page 296

Figure 7: Geographic Distribution of Translations of the Parable in the Dialects of the Napoleonic Empire, 1806-1812

Page 297

Figure 8: Bilingual Versions of Bergère-Monsieur Dialogues

Page 298

Figure 9: Alpes Maritimes- Communes by Language of Instruction, year XI (1803)

Page 299

Figure 10: Alpes Maritimes- the French-Italian Linguistic Border, 1806

Page 300

Figure 11: County of Nice, Communes by Language of Instruction, 1850

Page 301

Figure 12: Use of French as an Official Language in the Departments of the Empire after decrees published in the Bulletin des Lois

Page 302

Figure 13: Informal Diglossia in the Legal System in Spoken Contexts in the Observations des tribunaux sur le projet du code criminel de l'an IX

Page 303

Figure 14: Judges in the resort of the court of appeal of Genoa by origin

Page 304

Figure 15: Judges in the jurisdiction of the court of appeal of Trier by origin

Page 304

Figure 16: Francophone judges in the jurisdiction of the appeal court of Genoa by origin

Page 305

Figure 17: Francophone judges in the jurisdiction of the appeal court of Trier by origin

Page 305

Figure 18: Distribution of Politically Seditious Priests by Department, 1804

Page 306 


\author{
Abbreviations \\ An - Archives nationales, Paris \\ AdAM - Archives départementales des Alpes Maritimes, Nice \\ AdBdR - Archives départementales des Bouches du Rhône, Marseille and Aix \\ AdHR- Archives départementales du Haut Rhin, Colmar \\ AdV- Archives départementales de Vaucluse, Avignon \\ BmR - Bibliothèque municipale de Rouen, Rouen \\ BnF - Bibliothèque nationale de France, Paris \\ HLF- Ferdinand Brunot, Histoire de la langue française
}

Ms Mbt- Manuscrits Montbret

Naf- Nouvelles acquisitions françaises 


\section{Introduction: Language, Empire and the New Regime}

This thesis is about the relation between language, identity and state formation in France and the French Empire during the Napoleonic period. It is about the efforts of the Napoleonic state to impose cultural homogeneity on the culturally diverse populations within its borders. It is also, and centrally, about how these populations, or at least those members of the population who engaged with the Napoleonic state, navigated the linguistic demands of the centre. In doing so it broaches two apparently distinct, but in reality closely related areas of historical enquiry- the relationship between Napoleonic imperialism and nationalist revival in Europe, and the process of integration and assimilation of the culturally and linguistically diverse populations of France.

The intersection between these issues is apparent in the conclusions drawn by Ferdinand Brunot, doyen of the history of the French language. At the end of his volume on the Revolutionary and Napoleonic period, Brunot summarised what he saw as the baleful impact of the Napoleonic episode on the status of French amongst the elites of Europe:

Les armées impériales avaient trouvé le français solidement implanté dans les classes aisées et les milieux instruits des pays qu'elles avaient conquis [...] les haines issues de la domination napoléonienne persistèrent ; elles s'ajoutèrent aux sentiments patriotiques nés des principes de la Révolution pour exalter les langues nationales au détriment de la nôtre. ${ }^{1}$

Brunot's conclusion pointed to a classic view of the Napoleonic episode, of Napoleon as the 'unwitting midwife' of European nationalism. ${ }^{2}$ It also implies a fundamental realignment of the relationship between the linguistic practices of the individual and the political order. The 'sentiments patriotiques' described by Brunot made the continued dominance of European culture and affairs by a foreign language intolerable. The proper medium of expression, the only one compatible with the political freedom of the newly significant national community, was the national tongue.

The irony of Brunot's assessment was that many, perhaps even a majority of the conscripts that made up the French armies commanded by Napoleon, did not themselves speak French as their

\footnotetext{
${ }^{1}$ F. Brunot, $H L F$ vol.xi pt. 2 p.348

${ }^{2}$ H. Kohn, 'Napoleon and the Age of Nationalism', Journal of Modern History vol. 21 no.1 (1955) p.30
} 
first language. These harbingers of French imperialism often took solace in the company of men from the same pays, speaking the local patois together to stave off homesickness. ${ }^{3}$ They were drawn predominantly from rural communities that retained a high degree of cultural and linguistic particularism during the period, though undergoing a process of cultural and linguistic assimilation unleashed by the Revolution and furthered by economic change and the efforts of the French state. ${ }^{4}$ Making Frenchmen, and making Italians, Germans or Dutchmen, were in reality very similar processes. As James C. Scott suggests, the construction of standardised languages was a central plank of state-building projects, and it was a process which concentrated power at the centre, devaluing local forms of knowledge by making them inadmissible for certain crucial functions, such as interactions with state institutions like law courts and schools. ${ }^{5}$

This thesis, however, is not just about the struggle to impose cultural and linguistic hegemony. Rather, it is about the linguistic strategies pursued by actors during a period when they faced increasing pressures towards linguistic conformity. The central argument of the thesis is that individuals faced a series of choices on a spectrum between the valorisation of local language against centralising pressures, or conformity in pursuit of social status and Parisian approval. Not only did actors select different strategies depending on the local social context, they often made different, even apparently contradictory, linguistic moves in different circumstances. The thesis will therefore concentrate on the elaboration of local knowledge, on the arguments about linguistic practice raised within Napoleonic institutions. It will reveal a dynamic process of negotiation between centre and periphery. While efforts to 'franciser' the population were buttressed by a discourse of modernization and social improvement, state agents on the periphery developed a sense of linguistic diversity variously as an intractable feature of society, as a feature of local

\footnotetext{
${ }^{3}$ A. Forrest, Napoleon's Men: The Soldiers of the Revolution and Empire (London, 2006) p.130

${ }^{4}$ E. Weber, Peasants into Frenchmen: The Modernization of Rural France, 1870-1914 (Stanford, 1976) pp.6794; P. McPhee, The Politics of Rural Life: Political Mobilization in the French Countryside, 1846-1852 (Oxford, 1992) p.21

${ }^{5}$ J.C. Scott, Seeing Like a State: How Certain Schemes to Improve the Human Condition Have Failed (New Haven, 1998) pp.71-2
} 
patrimony and even as the 'mother tongue', something integral to the sense of self of those who spoke it.

The role of language as a site for the construction of identity, of linguistic consciousness as a motor for human behaviour, is therefore of central importance. At the outset it should be noted that I do not adopt a position of ethnolingusitic or ethnocultural essentialism to explain attachment to languages other than French. I do not subscribe to the view expressed by sociolinguist Joshua Fishman that 'the overt and the symbolic interrelatedness between an ethnolanguage and its associated ethnoculture are merely latent and quiescent', or that these relationships between language and culture need only be 'rendered salient by those who first arrive at ethnolingusitic consciousness (usually teachers, preachers, scribes, and elites or proto-elites)' ${ }^{6}$ As Miroslav Hroch has observed, the social basis of many nationalist linguistic demands would seem to exclude ethnolinguistic determinism of the kind suggested by Herder, Fichte or Mazzini, even if their pronouncements had a significant influence on the way contemporaries thought about their own language. ${ }^{7}$ The relative novelty of the demands of linguistic nationalists in the nineteenth century, and the rapid development of standardised national languages by nationalist movements as such languages were required to buttress political claims, would also seem to point towards a transformation in the relationship between language and identity. ${ }^{8}$ The problem was not one caused by primordial cultural constructions but by new ways of understanding the relationship between language, politics and self.

The position I adopt throughout this study is that situating the claims and strategies of speakers in the historical context of Napoleonic imperialism and state building enables an understanding of the fluidity of the historical subjectivities held by those negotiating the new

\footnotetext{
${ }^{6} \mathrm{~J}$. Fishman, In Praise of the Beloved Language: A Comparative View of Positive Ethnolinguistic Consciousness (Berlin, 1997) p.3

${ }^{7}$ M. Hroch, Comparative Studies in Modern European History: Nation, Nationalism and Social Change (Aldershot, 2007) pp.85-7

${ }^{8}$ A.M. Thiesse, La création des identités nationales, Europe, XVIIle-XXe siècle (Paris, 1999) pp.76-81
} 
structures of state. This is not simply to insist upon the socially constructed, invented or imagined nature of identities, be they social, ethnolinguistic or national. ${ }^{9}$ Some scholars have come to see the use of terms such as 'invented' or 'imagined' as problematic because, removed from academic discourse, they can appear pejorative, as synonymous with terms like 'inauthentic', 'artificial' or 'made up', thus de-legitimizing claims of certain groups that aspects of their lifestyles deserve to be defended as 'heritage'.$^{10}$ Rather, it is to argue against a reductionist view of cultures as reified entities that somehow not only exist apart from the strategies and practices of individual actors, but which determine them. It is to start from the premise that identities are not fixed, and that individual selves pursue diverse strategies of identification, strategies that in the sphere of language can include the selection between linguistic codes in bilingual situations and the selection of linguistic form, such as a formal or informal mode of address. ${ }^{11}$ Individuals negotiate the social and cultural forces that form the context of their actions. This context also includes the normative orientations of speakers towards linguistic diversity, the linguistic ideologies and hierarchies according to which different languages and speakers are classified and ordered. ${ }^{12}$ The elaboration of arguments in favour of local knowledge such as languages other than French can be understood, it is argued, with reference to the social and cultural position of actors in relation both to the centralising forces emanating from Paris, with its attendant concern with officially sanctioned forms of knowledge, and the demands and contexts of local society.

With this theoretical position in mind, the rest of this introduction will focus on the historical context of the period. It will examine the two major historiographical trends with which the research

\footnotetext{
${ }^{9}$ This position is axiomatic amongst 'modernist' scholars of nationalism. See B. Anderson, Imagined Communities: Reflections on the Origins and Spread of Nationalism (London, 2006) p.6 ; Thiesse, création des identités p.11; C. Bertho, 'L'invention de la Bretagne : Genèse social d'un stéréotype' Actes de la recherche en sciences sociales vol.35 (1980) pp.45-62

${ }^{10}$ M. Avaza and G. Laferté, 'Dépasser la « construction des identités ? » Identification, Image Social, Appartenance', Genèses vol.61, no.4 (2005) p.137

${ }^{11}$ R. LePage and A. Tabouret-Keller, Acts of Identity: Creole-based Approaches to Language and Ethnicity (Cambridge, 1985) ; T. Omoniyi 'Hierarchy of Identity', T. Omoniyi and G. White (eds.) The Sociolinguistics of Identity (London, 2006)

${ }^{12}$ K.A. Woolard, 'Language Variation and Cultural Hegemony: Toward and Integration of Sociolinguistic and Social Theory', American Ethnologist vol.12 no.4 (1985) pp.738-748
} 
is in dialogue- on Napoleonic cultural imperialism and modernization theory. It will, firstly, suggest how the reorientation of Napoleonic studies towards the dynamics of state building has provided important new understandings of the problems of governance during the period. The literature on modernization theory, in contrast, appears to me to have limited understandings of linguistic history in two ways. Firstly, it has focused attention narrowly on political discourse and state action as an agent of modernization, leading to a vision of the French state as a monolithic entity acting upon society from outside it, thus ignoring the complexity of the state-society interface, of the interplay between state power and the reproduction of social structure, particularly in the context of language. Secondly, it has shaded into a teleological vision of French history, which has led historians to reproduce the various prejudices and stereotypes of the elites who tended to dominate the production of source material. Speakers are thereby denied subjectivity, as social position and cognitive capacity are thought to be determined by the 'backwardness' of their language. In this introduction, I will outline both the state-society and subjectivity problems. Finally, I will suggest how this thesis, making use of now well-established theoretical developments in the fields of sociology and sociolinguistics, will seek to contribute both to understandings of the linguistic history of France and state-formation during the Napoleonic period.

\section{The Centralising Impulse: Napoleonic Cultural Imperialism}

If Brunot's vision of a linguistically inflected European national awakening sparked off by the principles of the Revolution and galvanised in response to Napoleonic domination now appears a little dated, it is because the past thirty years have seen a fundamental reassessment of the period and its wider significance for the history of modern Europe. Stuart Woolf's thesis on Napoleon's integration of Europe reinvigorated the history of a period that perhaps had focused rather too much on the spider at the centre of the web, on the genius and failures of the Corsican on the make, 
rather than on the character of French state-building and Imperialism. ${ }^{13}$ As the French scholar Aurélien Lignereux has recently argued, the significance of this project of Napoleonic governance lay precisely in the complicated ways in which it bisected 'national' boundaries, both by its Universalist scope and in the quotidian struggle to impose order on society. ${ }^{14}$ Much of this work has focused on the most prominent features of state-building during the period- the quest for law and order, conscription and the fight against social banditry. Work such as that of Charles Esdaile on the Peninsular War caution against anachronistic assumptions about the national or patriotic content of popular resistance to French rule where the social preconditions for national sentiment did not yet exist. ${ }^{15}$ Within Napoleonic Europe, this struggle was closely related to the most prominent feature of the Napoleonic state, its thirst for conscripts. Likewise, in the satellite state of the kingdom of Italy, brigandage was primarily a response to deteriorating rural conditions, particularly the demands of the Napoleonic state for tax and conscripts, rather than a nationalist reaction to Napoleonic domination, and what national sentiment was evident seems to have arisen from those fighting in the Italian regiments of the Grande Armée. ${ }^{16}$

The exigencies of war certainly necessitated a transformation in the role of the state in the lives of the people. ${ }^{17}$ Yet it would be wrong to assume that state building was driven solely by material concerns. Research by historians such as Michel Brunet, Michael Broers and Michael Rowe has revealed the broader significance of the period for European state building processes

\footnotetext{
${ }^{13} \mathrm{~S}$. Woolf, Napoleon's Integration of Europe (London, 1991)

${ }^{14}$ A. Lignereux, L'empire des français: $1799-1815$ (Paris, 2012) p.119

${ }^{15}$ C. Esdaile, Fighting Napoleon: Guerrillas, Bandits and Adventurers in Spain, 1808-1814 (New Haven, 2004) p.89; see also the essays in C. Esdaile (ed.), Popular Resistance in the French Wars: Patriots, Partisans and Land Pirates (Basingstoke, 2005)

${ }^{16}$ A. Grab, 'Army, State and Society: Conscription and Desertion in Napoleonic Italy', Journal of Modern History vol.67 no.1 (1995) pp.25-54 ; A. Grab, 'State Power, Brigandage, and Rural Resistance in Napoleonic Italy', European History Quarterly vol.25 no.1 (1995) pp.39-70

${ }^{17}$ A. Forrest, Conscripts and Deserters: The French Army and Society during the Revolution and Empire (Oxford, 1989) p.4
} 
respectively in Northern Catalonia, Northern Italy and the Rhineland. ${ }^{18}$ Meanwhile, for the metropole, Isser Woloch's work on the 'New Regime' has demonstrated the importance of the Revolutionary and Napoleonic period in the creation of a new political culture centred on the reformed state institutions. ${ }^{19}$ While all of this research is concerned with the process of state formation, the authors' shared ambition was not a simplistic account of bureaucratic rationalisation or rising state power, although, it must be granted, this is a part of the story. ${ }^{20}$ They demonstrate that the project of Napoleonic governance, as understood by contemporaries, was more profoundly about the modernization of state and society, about the export of what had become an authoritarian and hierarchical 'French Model' of administration that would ensure social progress. ${ }^{21}$

A starting point for this thesis, therefore, is that Napoleonic governance as a project cannot, contrary to the suggestion of Alexander Grab, be reduced to the practicalities of realpolitik. ${ }^{22}$ Nonetheless, to employ the concept of cultural imperialism, as historians such as Stuart Woolf and particularly Michael Broers have in relation to the Napoleonic project, remains controversial. ${ }^{23} \mathrm{As}$ Stephen Englund argues, drawing parallels between Napoleonic domination in Europe and the European colonialism of the later nineteenth century are problematic, and not only on the basis of scale. The latter was buttressed by racism in a way that Napoleonic imperialism, at least explicitly, was not. Indeed, the Italians studied by Broers, could point towards the great contribution made by their forebears to a shared European culture. ${ }^{24}$ It was Stuart Woolf who initially pointed historical enquiry on Napoleonic period in the direction of cultural imperialism, and his focus was as much on

\footnotetext{
${ }^{18}$ M. Broers, Napoleonic Imperialism and the Savoyard Monarchy, 1773-1821: state building in Piedmont (Lewiston, 1997); M. Brunet, Le Roussillon : Société contre l'état 1780-1820 (Toulouse, 1986) ; M. Rowe, From Reich to State: The Rhineland in the Revolutionary Age, 1780-1830 (Cambridge, 2003)

${ }^{19}$ I. Woloch, The New Regime Transformations of the French Civic Order, 1789-1820s (London, 1994)

${ }^{20}$ C.H. Church Revolution and Red Tape: The French Ministerial Bureaucracy, 1770-1850 (Oxford, 1981) p.73

${ }^{21}$ Woolf, Napoleon's Integration pp.124-32

${ }^{22}$ A. Grab, 'Napoleon: A civilizing missionary or a pragmatic imperialist?', Selected Papers, Consortium on Revolutionary Europe 1750-1850 (2008) pp.238-249

${ }^{23}$ M. Broers, The Napoleonic Empire in Italy: Cultural Imperialism in a European Context? (Basingstoke, 2005); M. Broers, 'Cultural Imperialism in European Context? Political Culture and Cultural Politics in Napoleonic Italy', Past and Present no.170 (2001) pp.152-180 ; S. Woolf, 'French Civilization and Ethnicity in the Napoleonic Empire', Past and Present no.224 (1989) pp.96-120

${ }^{24}$ S. Englund, 'Monstre Sacré: The Question of Cultural Imperialism and the Napoleonic Empire', The Historical Journal vol.51 no.1 (2008) pp.215-250
} 
a shared European sense of cultural superiority, rather than a specifically French one. ${ }^{25} \mathrm{It}$ is certainly true, as William Max Nelson has argued, that many of the 'technologies of biopolitics' employed by the Napoleonic state- the cadastre, descriptive statistics- were pioneered in a colonial context before the Revolution. ${ }^{26}$ The dual identity of Joseph-Marie Degerando as both Napoleonic administrator and the author of a seminal text on anthropological practice for the Sociéte des observateurs de I'homme is a rather neat illustration of this point. ${ }^{27}$ However, to draw the comparison without recognising that the techniques of describing and managing society were employed in very different contexts, and under a different set of power relations, is to risk a flattening of historical experience of precisely the kind bemoaned by Englund. ${ }^{28}$

Despite these caveats, a central tenet of this thesis is that a form of linguistic imperialism was a feature of French political and social power structures during the Napoleonic period. Even a cursory examination of the archive reveals that a strong, pro-French linguicism, an assumption that French was the foremost language of civilization, influenced the behaviour of historical actors. If linguistic imperialism is to be understood, according to Robert Phillipson, as the assertion and maintenance of the dominance of one language and its speakers by the establishment and continuous reconstruction of structural and cultural inequalities between languages within a context of asymmetric interaction between centre and periphery, then it will be argued that the term is appropriate to describe the politics of language under Napoleon. ${ }^{29}$

The desire to make Frenchmen, to integrate the diverse populations of the French state, was a prominent feature of Revolutionary discourse. Mona Ozouf's seminal essay on the discourse of regeneration demonstrates how central the making of Frenchmen was to the political culture of the

\footnotetext{
${ }^{25} \mathrm{~S}$. Woolf, 'The Construction of a European World-View in the Revolutionary-Napoleonic Years', Past and Present no.137 (1992) pp.72-101

${ }^{26}$ W.M. Nelson 'Colonizing France: Revolutionary Regeneration and the First French Empire', S. Desan, L. Hunt and W.M. Nelson (eds.) The French Revolution in Global Perspective (London, 2013) pp.83

${ }^{27}$ Nelson, 'Colonizing France' pp.84-5; J.M. Degerando, On the Observation of Savage Peoples F.C.T. Moore (trans.) (London, 2004) ; On Degerando and the société des observateurs de l'homme see J.-L. Chappey La société des observateur de l'homme, 1799-1804 : des anthropologues au temps de Bonaparte (Paris, 2002) ${ }^{28}$ Englund, 'Monstre Sacré' p.242

${ }^{29}$ R. Phillipson, Linguistic Imperialism (Oxford, 1992) p.47
} 
period, with the Revolutionaries eager to transform the habits and customs of their fellow citizens to enable them to throw off the yoke of the old regime and govern themselves. ${ }^{30}$ This urge to throw off the old, to modernize the culture of the French population, implicated apparently trivial features of individual behaviour in politics. As one historian recently phrased the problem, the Revolution 'politicized the everyday', it made the bodily comportment of French citizens, the way they dressed, carried themselves and even spoke, a concern for the state. ${ }^{31}$ As the work on the 'Revolutionary mentality' by two past masters of the period, Richard Cobb and Albert Soboul, demonstrates, an individual undermined his revolutionary credentials by insisting on honorifics like 'monsieur' or refusing to be addressed as 'tu' in place of the deferential 'vous', while there was little more aristocratic than a beard. ${ }^{32}$ This was accompanied with a thoroughgoing attempt to remodel French society. Amongst the most significant of these projects was the reconfiguration of administrative space into departments, effacing the old provinces, in a process that was intended to displace ties to regional entities thought to rival loyalty to the nation. ${ }^{33}$ The Revolutionaries sought to de-christianize time, creating a new calendar (a project the Napoleonic government only officially abandoned in 1806) and crucially taking the religious authority over holidays and festivals, previously held by the catholic Church, into the sphere of state power. ${ }^{34}$ Even the 'auditory landscape' shaped by village bells became an object of Revolutionary reformers, who sought to 'secularize and municipalize' the peals that structured the working and religious rhythms of everyday life. ${ }^{35}$

The language of the population became a central concern during the Revolutionary period, with figures such as the Abbé Grégoire and Bertrand Barère arguing for the need to universalise the

\footnotetext{
${ }^{30}$ M. Ozouf, L'homme régénéré: Essais sur la Révolution française (Paris, 1989) p.117

${ }^{31}$ L. Auslander, Cultural Revolutions: The Politics of Everyday Life in Britain, North America and France (Oxford, 2009) pp.3, 128

${ }^{32}$ A. Soboul, Les sans-culottes parisiens en I'an II (Paris, 1958) pp. 408-9 ; R. Cobb, 'The Revolutionary Mentality in France, 1793-4', History vol.42 no.147 (1957) p.188

${ }^{33}$ M.-V. Ozouf-Marignier, La formation des départements: la représentation du territoire français à la fin du $18^{e}$ siècle (Paris, 1989) ; T. Margadant, Urban Rivalries in the French Revolution (Princeton, 1992)

${ }^{34}$ N. Schusterman, Religion and the Politics of Time: Holidays in France from Louis XIV through Napoleon (Washington, 2010) p. 121

${ }^{35}$ A. Corbin Village Bells: Sound and Meaning in the Nineteenth Century French Countryside (Columbia, 1998) p.4
} 
French language in order to bring enlightenment and sound judgement to the newly sovereign people. ${ }^{36}$ The Napoleonic period was less febrile a context than Paris in the year II, yet the Revolutionary desire to remake the population through state action remained a feature of the new regime under Napoleon. In the words of Michael Broers, the ideal Napoleonic administrator saw himself 'in the vanguard of modernity, [...] determined to impose cultural, administrative and political uniformity on French society'. ${ }^{37}$ Linguistic imperialism formed part of a broader discourse of 'social progress' and of 'good administration' that was frequently articulated by the governing elites of France throughout the nineteenth century, not least during the Napoleonic period when the issue of 'governance', of the state's role in regulating and improving society, was a prime concern. ${ }^{38}$ For this reason, one might even talk legitimately in terms of internal colonialism, or of what amounts to much the same thing, of the 'integration' of populations. ${ }^{39}$ The period saw the intensification of what Michael Hechter has referred to as the 'ethnic division of labour', or what Pierre Bourdieu might describe as the necessary conditions for the reproduction of social capital through legitimate language..$^{40}$ Speaking French properly was crucial to personal advancement during the period, and one of the key findings of this thesis is that French linguistic nationalism, and related problems of government and integration, did not simply disappear after Brumaire.

The Napoleonic state continued to make linguistic unification an explicit aim of policy. The majority of such efforts were directed towards the speakers of the other standardised languages spoken within the empire- German, Italian and Dutch- and were transparently aimed at securing French as the language of literate, elite communication. The regime sought to establish French as the official language of legal practice across the empire, although the need to compromise with local

\footnotetext{
${ }^{36}$ M. de Certeau, D. Julia and J. Revel Une politique de la langue : la Révolution française et les patois : l'enquête de Grégoire (Paris, 2002) ; P. Higonnet 'The Politics of Linguistic Terrorism and Grammatical Hegemony during the French Revolution', Social History vol. 5 no.1 (1980) pp.41-69

${ }^{37}$ M. Broers, Europe under Napoleon, $1799-1815$ (Oxford, 1996) p.60

38 Weber, Peasants pp.72-3; M. Broers, Napoleonic Empire in Italy p.15

${ }^{39}$ P. McPhee, 'A Case-study of Internal Colonization: The Francisation of Northern Catalonia' in Review, Fernand Braudel Centre for the Study of Economies, Historical Systems and Civilizations vol.3 no.3 (1980) p.401 ${ }^{40}$ M. Hechter, Internal Colonialism: The Celtic Fringe in British National Development (London, 1975) p.9; P. Bourdieu, Language and Symbolic Power (Cambridge, 1991) pp.67-72
} 
elites frequently militated against the rigid application of the general rule. Similarly, a command of French became a requirement for those seeking to take up a number of official positions within the French state. All newly appointed foresters had to be capable of drafting their reports in French, even if those already appointed were granted repeated exemptions from this requirement. ${ }^{41}$ French became a requisite for those seeking to take up a position as a primary school teacher, even if efforts to enforce this diktat through the Jury $d^{\prime}$ instruction proved difficult where local elites were committed to another language.

While it was the speakers of standardized languages like German and Italian that induced the greatest anxiety within the Napoleonic regime, other linguistic minorities were also considered a threat to national cohesion and thus became the target of efforts at francisation. The Jewish communities of Western Europe enjoyed unprecedented freedoms under Napoleon, but state protection brought with it a dirigiste religious policy. The state policed religious institutions and appointments, and much as with the appointment of foresters, a deadline for the appointment of Francophone rabbis was fixed in the December 1806 religious statutes for the Jewish faith. ${ }^{42}$ While the speakers of regional languages were not targeted directly by legislation from the centre, state actors at the departmental level actively pursued the linguistic reform of the populations they administered. In November 1807, the Société d'émulation, a group sponsored by the departmental administration of the Hautes-Alpes offered a prize of 300 francs for the best dictionary of 'locutions ou expressions vicieuses, usitées dans le département des Hautes-Alpes, soit contre la langue française, soit contre la prononciation, avec les corrections de ces mêmes fautes'. The work was intended to 'prémunir les jeunes-gens et les personnes peu instruits contre les vices ordinaires du langage'.${ }^{43}$ The members of the Société were, in their own words, committed to the 'amélioration' of

\footnotetext{
${ }^{41}$ Journal de l'empire 8 Jan. 1806 p. 2

42 Bulletin des lois (1808) ser. 4 no. 187

${ }^{43}$ Journal d'agriculture et des arts des Hautes-Alpes no. 4 (1807) p.185
} 
the department, and correcting the language of those they administered was the crucial first step. ${ }^{44}$ This rhetoric of improvement was not isolated, as will be argued in the first chapter of this thesis.

\section{Language and the Making of Modern France}

There can be little doubt that the Napoleonic regime continued to be concerned with the language of its population. However, one weakness of research on the history of language is that it has rarely gone beyond political discourse. We have a clear sense of how, at an elite level, language came to constitute an important element of French national identity. ${ }^{45}$ We understand how the enlightenment fear that linguistic diversity, through the vagaries of translation, would ferment civil discord manifested itself in the belligerent linguistic policies adopted by the French state during the Terror. ${ }^{46}$ Yet historians have turned surprisingly little attention towards the evolving structures of societal bilingualism amongst the population of the French state; they have tended to ignore the transmission of attitudes towards language below the level of elite discourse, and have directed little attention towards the important question of how the multilingualism of the French territory affected the development of the French state. We are left with declarations such as that of David Bell, that it was the Revolution that politicised the issue of language, even though he himself admits that this forms part of a longer process of linguistic integration stretching back before the Revolution ${ }^{47}$ In short, we are left with a mode of historical analysis in which the state, or political discourse more generally, is thought to be constitutive of cultural phenomena. ${ }^{48}$ The political sphere is understood as existing outside of society and acting upon it, autonomous of social elites and their

\footnotetext{
${ }^{44}$ Journal d'agriculture et des arts des Hautes-Alpes no. 1 (Apr. 1806) p.1

${ }^{45}$ D. Bell, The Cult of the Nation in France: Inventing Nationalism, 1680-1800 (Cambridge Mass., 2001) pp.169199

${ }^{46} \mathrm{H}$. Aarsleff, From Locke to Saussure : Essays on the Study of Language and Intellectual History (London, 1982) p.32 ; M. Lauzon, Signs of Light: French and British Theories of Linguistic Communication, 1648-1789 (London, 2010); S. Rosenfeld, A Revolution in Language: The Problem of Signs in Late Eighteenth Century France (Stanford, 2001)

${ }^{47}$ Bell, Cult pp.171-2

${ }^{48}$ G. Steinmetz, 'Introduction: Culture and the State' in G. Steinmetz (ed.) State/Culture: State-formation after the Cultural Turn (London, 1999) p.3
} 
interests. ${ }^{49}$ This is reinforced by the image of the French state as a bloc, highly centralised and hierarchical, acting on society at the behest of Paris, a vision making the size of the bureaucracy and the share of national wealth expropriated by the state central to historical analysis. ${ }^{50}$

State theory and the focus on political culture in historical studies have undoubtedly made space for a more nuanced understanding of historical development during the Revolutionary and Napoleonic period beyond social determinism. Yet there has generally been a growing dissatisfaction with the overemphasis on political discourse which has lead historians to orient their research to fields of social and political practice as a way of breaking with sometimes stale political narratives and reintroducing social change to historical accounts. Where historians have turned their attention to the nature of social and cultural practice a far more complex picture of socially and historically situated change has emerged. This is particularly true when discussing the role of the French state in the cultural construction of the modern French citizen. The rise of mass literacy, for example, cannot only be attributed to the development of the French school system, but was part of a long term process of social and cultural change. ${ }^{51}$ This counter-intuitive finding becomes explicable once it is understood that French educators, even under the Third Republic, were far more responsive to local concerns than had previously been assumed, and that the French school cannot be understood solely as an imposition from the centre, but must also be considered within the social and cultural context in which it functioned. ${ }^{52}$ More generally, historians are increasingly aware of how local institutions can mediate national trends and centralising processes, creating unique iterations of social and political formations. ${ }^{53}$ Galvanised by this desire to decentre political narratives, historians have focused on the everyday experience of important historical developments, on the way

\footnotetext{
${ }^{49}$ T. Skocpol States and Social Revolutions: A Comparative Analysis of France, Russia and China (Cambridge, 1989)

${ }^{50}$ P. Rosanvallon, L'état en France de 1789 à nos jours (Paris, 1999) pp.10-11

${ }^{51} \mathrm{~F}$. Furet and J. Ozouf, Reading and Writing: Literacy in France from Calvin to Jules Ferry (Cambridge, 1982) p.47

${ }^{52} \mathrm{~J} .-\mathrm{F}$. Chanet, L'école républicaine et les petites patries (Paris, 1996) pp.27-9

${ }^{53}$ C. Ford, Creating the Nation in Provincial France: Religion and Political Identity in Brittany (Princeton, 1993) p.8
} 
'national' historical development and popular culture interact, and on writing the history of these developments from below. ${ }^{54}$

While the centralising and unifying impulse of the Napoleonic state's attitude towards language will be further illustrated across the subsequent chapters of this thesis, it will also become clear that to focus only on the efforts of the centre is to obscure the complexity of how such efforts unfolded in practice. In this respect historiographical developments relating to the cultural integration of the French population that emphasise the complexities of this process are crucial. Historians of France writing on the subject of language have tended to posit a dichotomy between the modern, which they characterise as Francophone and literate, and the archaic or traditional, the latter manifested in the local dialects that were supposedly manifestations of culturally independent folk or popular culture. The linguistically and culturally integrated nation-state is understood by many scholars as the exemplary form of modern political organisation, associated with the socioeconomic forms of modernity- market capitalism and industrialized production. ${ }^{55}$ Consequently, the passage to the modern world is often taken to involve the displacement of these languages, and the popular or folk cultures which they are supposed to constitute, by a national mass cultural characterised by standardised languages, manifested in mass forms of media like newsprint or the novel, through a process of acculturation, or culture shift. ${ }^{56}$ In the French context this perspective was most notably expressed by Eugen Weber in his classic study, Peasants into Frenchmen. Weber consulted an enormous range of sources, from ethnographic treatises and folklore collections to administrative records. His work led him to conclude that the population of nineteenth century France was characterised by a tremendous degree of social, cultural, and indeed linguistic diversity. ${ }^{57}$

\footnotetext{
${ }^{54}$ G. M. Joseph and D. Nugent, 'Popular Culture and State Formation in Revolutionary Mexico', G. M. Joseph and D. Nugent (eds.), Everyday Forms of State Formation: Revolution and the Negotiation of Rule in Modern Mexico (London: 1994) pp.12-18; M. Van Ginderachter and M. Beyen (eds.), Nationhood from Below: Europe in the Long Nineteenth Century (Basingstoke, 2012)

${ }^{55}$ E. Gellner, Nations and Nationalism (Oxford, 1983)

${ }^{56}$ Anderson, Imagined p.25. On this process in the context of Ancien Régime France see R. Muchembled, Culture populaire et culture des élites dans la France moderne XVe-XVIIle siècle (Paris, 1978)

${ }^{57}$ Weber, Peasants p.ix
} 
In Weber's telling, a process of modernization, running from the end of the Franco-Prussian war up to the start of the First World War, saw the patchwork reality of French rural society replaced with a more homogenous national culture. The primary agents of change identified by Weber were economic, but they were seconded by the tutelage of agents of state, figures like the recruiting sergeant and the schoolteacher. ${ }^{58}$

Weber's book, more than any other, focused attention on the cultural changes associated with the passage to modernity, on the behaviours and patterns of thought of the mass French population. It has brought to the fore the question of when the French truly came to 'feel' French, and a significant part of this process was the adoption of the French language by a formerly polylingual population. ${ }^{59}$ Yet the grand sweep of any argument invoking modernity in the manner of Weber inevitably draws criticism. This vision of modernity and archaism locked in struggle appears compelling because it structured the social imaginary of those government officials who composed so much of the historical record. The difficulty is that linguistic diversity was a central part of the way in which contemporaries understood social variation and change. In adopting an emic approach and considering the perspective of contemporaries, it may make sense to talk of a French speaking peasant in Provence as 'modern', since speaking patois constituted a central part of the social representation of the peasantry- it was a feature of their isolated backwardness as understood by elite observers. Once the historian slips towards an etic analysis, making modernity an objective category of analysis rather than an ideological characteristic of historical actors such claims can become problematic.

Modernity as an analytical category often seems to add up to little more than a series of phenomena observable in the modern world, but without the sort of clear structural relationship that would give the term explanatory force. As a result it is difficult to sustain a coherent

\footnotetext{
${ }^{58}$ Weber, Peasants pp.298-9, 329-38

${ }^{59}$ P. Barral, 'Depuis quand les paysans se sentent-ils français?', Ruralia no.3 (1998) pp.7-21
} 
periodization. Secularization is generally considered a characteristic feature of modernity, yet the picture here is muddled. Michel Vovelle's classic study of Provence, for example, shows a decline in almost all outward manifestations of religious devotion across the eighteenth century, yet according to Gérard Cholvy and Yves-Marie Hilaire, the 1830s onwards witnessed a striking revival in devotional practices dedicated to the Virgin Mary, from officially sanctioned confréries to apparitions. ${ }^{60}$ The politicization of the French population, generally understood as the emergence of a modern class consciousness, has proven equally difficult to date. Maurice Agulhon, for example, has pointed to an early politicization in Provence emerging from the particular forms of sociability offered by the clustered settlements of the area, which is to say from the features of traditional society. ${ }^{61}$

Other phenomena point to a less spectacular transformation, to at best a hazy boundary between the modern and the pre-modern. The development of mass literacy appears even less compatible with a short and sharp process of modernization, at least to judge by the ability to sign a marriage certificate, a capacity that spread gradually across French society from the Reformation onwards. ${ }^{62}$ Reliable statistics for language usage during the nineteenth century are notoriously difficult to come across, although it seems likely that substantial proportions of the population spoke a language other than French well into the nineteenth century. The data collected in 1863 by Victor Duruy, then Minister of Education, on the linguistic competence of primary school pupils, is problematic. It requires us to believe, for example, that the Bouches-du Rhône in western Provence was entirely Francophone, while the neighbouring department of the Var, home to the famously Francophone port city of Toulon lacked a single French speaking commune. ${ }^{63}$ Yet the survey probably can be taken as indicative of widespread linguistic diversity, whereby French was not

\footnotetext{
${ }^{60}$ M. Vovelle, Piété baroque et déchristianisation en Provence au XVIIIle siècle (Paris, 1978) pp.322-6 ; G. Cholvy and Y.-M. Hilaire, Histoire religieuse de la France, 1800-1880 (Toulouse, 2000) pp.203-10

${ }^{61} \mathrm{M}$. Agulhon, La République au village: Les populations du Var de la révolution à la lle République (Paris, 1979) pp.471-2

62 Furet and Ozouf, Reading p.47

${ }^{63}$ Weber, Peasants pp.498-501
} 
necessarily the first language of a majority of the French population. The paucity of data makes it impossible to plot a precise chronology of language shift, although studies of the more outlying linguistic minorities speaking non-romance varieties- such as the Breton-speakers of the western part of Brittany and the Flemish speakers of the Nord-indicate that the decisive turning point in favour of French may have been as late as the period following the Second World War. ${ }^{64}$ Yet amidst all this ambiguity it is clear that where France at the end of the eighteenth century was characterised by a large, if unquantifiable, degree of linguistic diversity, linguistic homogeneity had become the order of the day by the end of the twentieth, with a 1999 survey showing ninety percent of those brought up in France spoke uniquely or primarily in French with their parents during childhood, the generally accepted standard for the measurement of language shift. ${ }^{65}$

An even more fundamental difficulty with the modernization approach emerges from the ambiguity of 'modern' as an analytical concept. Close attention to this process in practice, however, has broken down the easy distinction between modernity and archaism, national and local. It is easy to point to apparently modern practices coexisting alongside archaic ones, or to ostensibly modern actors behaving in pre-modern ways. Migrants to Paris from the rural department of the Creuse, for example, did not appear to assimilate to the national norms of the capital, but to gather in their own regional conglomerates within the city, where they would speak the regional patois and eat regional food. Moreover, this economic migration did not break down older models of social activity and turn peasants into modern proletarians, so much as buttress existing modes of production, as the

\footnotetext{
${ }^{64} \mathrm{H}$. Rykeboer, 'Dutch/Flemish in the North of France', Journal of Multilingual and Multicultural Development vol.23 no.1-2 (2002) pp.22-35 ; F. Broudic, La pratique du breton de l'ancien régime jusqu'à nos jours (Rennes, 1995) pp.59-72, 351; The difficulty in applying this chronology to Romance speaking France is that the sources used to study these communities emerge from their very linguistic particularity. Fañch Brodic, for example, works from the appointment of Breton language court translators appointed to non-francophone witnesses and accused. It is unclear whether such translators were absent elsewhere because they were not needed or because there was no legal custom of appointing them. Ethnographic surveys that have taken place in the south of France have pointed to a high degree of variation in the rate of language shift between different communities. D. Hadjadj, Parlers en contact aux confins de l'Auvergne et du Forez (Clermont-Ferrand, 1983) pp.132, 182

${ }^{65} \mathrm{~F}$. Clanché, 'Langues régionales, langues étrangères : de l'héritage à la pratique', INSEE Première no. 830 (2002) http://www.dglflf.culture.gouv.fr/lgfrance/IP830.pdf accessed 22/04/2013; C. Veltman 'Theory and Method in the Study of Language Shift', J.R. Dow (ed.) Language and Ethnicity (Amsterdam, 1991) pp.148-52
} 
migrants used the money they earned to pursue the classic peasant dream of a holding sufficient to support a household. ${ }^{66}$ Research has demonstrated how modernization involved a complex process of accommodation, rather than a simple imposition or displacement of new, modern national forms in place of old, traditional or regional ones. Caroline Ford has shown how the Catholic Church in Brittany played an important role in mediating national trends and centralising processes, creating unique iterations of social and political formations. ${ }^{67}$ Writing on French Flanders, Timothy Baycroft has attempted to move beyond the dualist models of modern and archaic, national and regional, to show how local elites, those most deeply enmeshed in national and modern spheres of action, embraced regionalism as a way of buttressing their local authority. ${ }^{68}$ Jean-François Chanet, in his study of the primary schools of the Third Republic, has revised the austere image of the classroom as a simple motor of cultural assimilation. The primary school according to Chanet was the site of a complex process of accommodation between local and national cultures, where local hymns, folklore and even the local language might be employed to further the broader aim of national unity.$^{69}$

What all this research has in common is a dissatisfaction with approaches to historical change that overemphasises the top down role of the centre in diffusing national culture. As Peter Sahlins has observed of the Cerdagne, even in the eighteenth century, both villages in dispute with their neighbours over pastureland and propertied elites were keen to characterise themselves in national terms in some spheres, in local terms in others. ${ }^{70}$ Similarly, Stéphane Gerson has argued that local memories became more important, not less, in a context of modernizing state and economic structures. ${ }^{71}$ The modern and the traditional, the national and local, it seems, were not

\footnotetext{
${ }^{66}$ K. Silva, 'Immigration, Occupation and the Boundaries of Limousin Solidarity in Nineteenth Century Paris', French Historical Studies vol.35 no.1 (2012) pp.61-92

${ }^{67}$ Ford, Creating the Nation p.8

${ }^{68}$ T. Baycroft, Culture, Identity and Nationalism: French Flanders in the Nineteenth and Twentieth Centuries (Woodbridge, 2004) p.18

${ }^{69}$ Chanet, L'école républicaine pp.301-8

${ }^{70}$ P. Sahlins, Boundaries: The Making of France and Spain in the Pyrenees (Oxford, 1991) p.165

${ }^{71}$ S. Gerson, The Pride of Place: Local Memories and Political Culture in Nineteenth Century France (London, 2003)
} 
homogenous and opposed entities, but were co-constructed. As Gerson writes, the local was a 'product of modernization', and it was 'at the juncture of Paris and the localities' that French identity was articulated. ${ }^{72}$

This is a particularly germane observation in relation to language. Weber unambiguously connected the spread of French to the process of modernization. As he wrote, 'patois clung on longest where practice and thought were closest', since 'French [...] prizes abstract terms over concrete ones', implying that only certain languages are suitable to the expression of modern selfhood. ${ }^{73}$ Barnett Singer has claimed in similar fashion that 'language alone could generate true critical values; and rural dialects, [...] were too concrete to permit rivalry with the normative monopoly enjoyed by notables'.$^{74}$ From this perspective, speaking French is considered not as a simple act of symbolic identification with modernity or the French nation-state. Rather, speaking the language of the nation made individuals French and modern in a real, tangible way, in that it determined cognition and shaped culture. Singer and Weber would appear to accept the view of Herder, and later linguistic anthropologist Benjamin Lee Whorf, that language determines cognition, and consequently that each language constitutes a distinct and unique relationship with the external world- that, to cite Herder's aphorism, 'a nation has no idea for which its language has no word'. ${ }^{75}$

It is uncontroversial to claim that language is shaped by cultural and social practice. The best known example of this phenomenon is probably the reflection of kinship systems in the lexis of different languages. Briefly put, kinship relations that are of particular importance in a society are more likely to have their own lexical items. ${ }^{76}$ One might also point to the changing usage of forms of address in French. Originally, the 'vous' form was used to mark deference- the peasant would

\footnotetext{
72 Gerson, Pride p.8

${ }^{73}$ Weber, Peasants pp.92-3

74 B. Singer, Village Notables in Nineteenth Century France: Priests, Mayors, Schoolmasters (New York, 1983) p. 4

75 B.L Whorf, Language, Thought and Reality: Selected Writings of Benjamin Lee Whorf (Cambridge Mass., 1956) ; J.G. Herder, Outlines of a Philosophy of the History of Man T. Churchill (trans.) (London, 1800) p.233 ${ }^{76}$ P. Trudgill, Sociolinguistics: An Introduction to Language and Society (London, 2000) pp.16-18
} 
address his lord as 'vous' while the lord his serf using 'tu'. As attitudes towards social stratification changed, marking status in this way became unacceptable. Gradually, practice altered in responses to these new attitudes, so that today 'vous' marks formality and 'tu' intimacy. ${ }^{77}$ The inverse of this proposition, that language shapes culture, is far more controversial. There are some well substantiated 'Whorfian' effects, whereby language appears to influence cognitive processes. The way individuals negotiate space, for example, seems to be affected by the way in which particular linguistic communities frame spatial references, either as 'relative' (egocentric perspectives such as 'left' and 'right'), 'intrinsic' (perspectives relative to other objects such as 'besides' or 'in front of') or absolute (in relation to 'north' or 'south'). ${ }^{78}$

Few would claim that this adds up to the stronger formulation- that language determines thought- implied by Singer's claim that speaking dialect hobbled the critical faculties of rural dwellers. ${ }^{79}$ The claim reflected contemporary statements about language, although in practice there are examples of ideas permeating linguistic barriers through mechanisms such as lexical borrowings and neologisms.$^{80}$ Amongst Gaelic speaking communities in Scotland, for example, new words have emerged allowing speakers to distinguish between blue and green where previously a single colour term was in use, and to organise time in accordance with the 12 month calendar as understood in London or Rome, rather than the older Gaelic system based on overlapping weather and agricultural schedules intermingled with the ritual seasons.$^{81}$ Other scholars argue that languages provide their

\footnotetext{
${ }^{77}$ R. Brown and A. Gilman, 'The Pronouns of Power and Solidarity', T.A. Sebeok (ed.) Style in Language (Cambridge Mass., 1960) pp.255-261 ; This is a slight oversimplification, because selection between $T$ and $V$ forms is always an 'act of identity', an active attempt to define the nature of the relationship between speakers, and therefore mobilises potentially competing visions of society; P. Gardener-Chloros 'Tu/Vous Choices: An Act of Identity?', W. Ayres-Bennett and M.C. Jones (eds.) The French Language and Questions of Identity (London, 2007) pp.106-7; Controversies over T/V pronoun selection during the Revolutionary and Napoleonic period are examined in chapter 3 of this thesis. [check]

${ }^{78}$ A. Majid, M. Bowerman, S. Kita, D.B.M. Haun and S.C. Levinson, 'Can Language Restructure Cognition? The Case for Space', Trends in Cognitive Sciences vol. 8 no.3 (2004) pp.108-114

79 J. Lucy, Language Diversity and Thought: A Reformulation of the Linguistic Relativity Hypothesis (Cambridge, 1992) p.3

${ }^{80}$ Certeau et. al., Une politique p.156 ; R. Harlow 'Some Languages are Just Not Good Enough', L. Bauer and P. Trudgill (eds.) Language Myths (London, 1998) pp.9-13

${ }^{81} \mathrm{~S}$. Macdonald, “'A bheil am feur gorm fhathast?": Some Problems Concerning Language and Culture Shift', Scottish Studies vol.33 (1999) pp.186-197
} 
speakers with ample tools to generate new expression, to adapt to changing cultural practices, be that through the borrowing of lexis or other internal mechanisms, so to assume, as Weber and Singer do, that the use of regional languages necessarily meant an adhesion to traditional modes of thought and identification to the exclusion of broader modern forms is problematic. This is not to deny the importance of the Whorfian effects identified by linguists, but merely to observe that aligning such claims with a set of dualities in historical writing- French and Patois, Modern and Traditional, Urban and Rural- can lead to oversimplified descriptions of society and obscure conflicts over linguistic practice and status that did not always align neatly with such dualities.

This problem is related to the controversy over the relationship between literacy and cognition, since the standardisation of a language is achieved largely through written text while dialect is associated with oral practice. Walter Ong, for example, has argued that orality represents a mode of consciousness structured by the impossibility of writing anything down, and that abstract reasoning arose only with the invention of literacy, which caused a transition from the world of sound to the world of sight. ${ }^{82}$ There are a number of possible objections to this theory; that it is implicitly ethnocentric, that it is based on an unconvincing account of the difference between hearing and seeing, that pre-literate cultures possessed equally important ways of externalizing knowledge- magic, paintings and sculpture, ritual and poetry- making Ong's claim that oral cultures are unable to deal in abstract categories or refer back to themselves dubious, while the validity of the evidence base underpinning his conclusions has also been questioned. ${ }^{83}$ Whatever the merits of Ong's model, the oral-literate dualism seems to break down when one considers the dynamic interactions between oral and literate culture in historical research ${ }^{84}$ Ballads and libels, for example,

\footnotetext{
${ }^{82}$ W.J. Ong, Orality and Literacy: The Technologizing of the Word (London,1982) ch.3 ; see also J. Goody, The Domesticaiton of the Savage Mind (Cambrdige, 1977)

${ }^{83}$ These critiques are drawn from Jonathon Sterne's essay on Ong, J. Sterne 'The Theology of Sound: A Critique of Orality', Canadian Journal of Communication vol.36 (2011) pp.207-25; see also J. Fabian Time and the Other: How Anthropology Makes its Object (New York, 2014) pp.119-21

${ }^{84}$ R. Fox, Oral and Literate Culture in England, 1500-1700 (Oxford, 2002) pp.11-2
} 
were oral forms that relied in part on printing and writing to circulate. ${ }^{85}$ The duality between 'oral' and 'literate' can be a misleading feature of historical analysis when what really matters is the uses to which readers put such tools. Oral literature was performed and those performing it took material not only from the repertoire of other singer storytellers, but from printed material. ${ }^{86} \mathrm{~A}$ similar criticism can be made of the duality between French and regional languages. As Peter Sahlins has observed of the Cerdagne, French, Catalan and Spanish were all put to use in different contexts, by historical actors and for different purposes ${ }^{87}$ The history of language, as Martyn Lyons has argued, needs to be understood not as an ineluctably transition to Francophone modernity, but in terms of the strategies pursued by historical actors embedded within a social and cultural context. ${ }^{88}$

\section{Diglossia and Standardisation: Language and Society}

Insisting that a language should be understood not as the repository of essentialized ethnic or cultural difference, but in terms of function as one aspect of social practice, places the issue firmly within the competency of the historian. Two closely related concepts drawn from sociolinguistics are indispensable to the historian seeking to write a history of language as practice, both of which I have mentioned above but which might here be explicitly delineated; diglossia and standardisation. Diglossia was a term first employed in a sociological context by Charles Fergusson, who used it to refer to the systematic manner in which certain language communities characterised by bi- or multilingualism apportioned social functions amongst different and explicitly designated linguistic codes. In such language communities it is possible to distinguish between high $(\mathrm{H})$ and low $(\mathrm{L})$ varieties based on the different contexts in which they are used. Generally, $\mathrm{H}$ varieties are those used for religious worship, in educational and official or legal contexts and for 'high' culture and literature. Conversely, L varieties are spoken in everyday conversations, in instructing servants and

\footnotetext{
${ }^{85}$ Fox, Oral and Literate pp.311-24

${ }^{86}$ D. Hopkin, Voices of the People in Nineteenth Century France (Oxford, 2012) pp.25-6

87 Sahlins, Boundaries pp.166-7

${ }^{88}$ M. Lyons, 'Regionalism and Linguistic Conformity in the French Revolution', A Forrest and P. Jones (eds.)

Reshaping France: Town, Country and Region in the French Revolution (Manchester, 1991) p.189
} 
for 'folk' culture. ${ }^{89}$ While Fergusson initially limited his use of the term to communities in which one variety was considered a dialect of the other, Joshua Fishman later expanded the definition to include all situations where a language community recognised two distinct linguistic codes and systematically employed them for different social functions. ${ }^{90}$ The virtue of Fishman's definition for the study of the Napoleonic period is that it distinguishes between bilingualism, understood as the capacity of members of the speech community to employ both varieties, and diglossia, the systematic distinction between languages on the basis of social function. ${ }^{91}$

Fishman's distinction thus allows us to consider situations in which the linguistic repertoire of the language community is unevenly distributed amongst its members, where social stratification is mirrored, or even heightened, by linguistic difference. This relates to a more generalized critique levelled by Alan Hudson at the haphazard manner in which sociolinguists have employed diglossia to describe situations that are distinct in both their genesis and sociolinguistic character. For Hudson, the central property of diglossia, as opposed to societal bilingualism, is that the ' $\mathrm{H}$ ' variety possesses no native speakers within the linguistic community. For this reason, situations described as genuinely diglossic by Hudson are most likely to arise where societies have adopted as an ' $\mathrm{H}$ ' variety a very standardised artificial norm that differs substantially from the spoken vernacular, or where the spoken vernacular has changed at a greater rate than the standardised ' $\mathrm{H}$ ' variety, necessitating a period of apprenticeship to achieve mastery over the prestige form. ${ }^{92}$ The significance of this stipulation regarding the absence of native speakers lies in the presumed differences in communicative practice that emerge. While not willing to discard the term diglossia, Britto describes this as the distinction between use-oriented diglossia, where code selection is informed by communicative context, and user-oriented diglossia, where code selection is a function of social

\footnotetext{
${ }^{89}$ C.A. Fergusson, 'Diglossia', Word vol. 15 (1959) pp.325-40 reprinted in P.P. Giglioli (ed.) Language and Social Context (Harmondsworth, 1972)

90 J.A. Fishman, 'Bilingualism With and Without Diglossia, Diglossia With and Without Bilingualism', Journal of Social Issues vol.22 no.2 (1967) pp.29-38

${ }^{91}$ Fishman, 'Bilingualism' p.33

92 A. Hudson, 'Outline of a Theory of Diglossia', International Journal of the Sociology of Language vol.157

(2002) pp.6,21-3
} 
identity. ${ }^{93}$ In the former, for example, the use of ' $\mathrm{H}$ ' and ' $\mathrm{L}$ ' varieties is generally symmetrical and reciprocal within a given context, whereas in the latter asymmetrical communicative practices see elites using ' $H$ ' varieties to respond to lower class actors speaking in ' $L$ '. ${ }^{94}$

Most of the situations within the Napoleonic Empire cannot be considered an ideal manifestation of either use- or user-oriented diglossia, but incorporate some features of both. Peter Sahlins on the Cerdagne, for example, observes that knowledge of French and Castilian became integral to the communicative repertoire of assimilated local elites, but that different communicative functions, such as petitions to state authority or conversations with the cosmopolitan clientele found in the inn, equally determined the use of French in place of Catalan. ${ }^{95}$ The somewhat later example of Pierre-Jakez Hélias, the bilingual Breton peasant whose biography, the Horse of Pride, is cited by Martyn Lyons, gives a similar impression- Breton was the language of the household, of his mother's old religious books, while French was the public language. ${ }^{96}$ The point is that communities across the empire were characterised both by different distributions of linguistic capacity as well as different sets of linguistic practice, and this variation is crucial to any understanding of the way Napoleonic efforts to standardise linguistic practice were negotiated by individuals locally.

Such efforts must also be understood in relation to the notion of standardisation, schematised by Einar Haugen as a model of 'linguistic development' ${ }^{97}$ Standardisation in any sphere of activity means homogenising and generalising a given set of norms, and this is precisely the sense in which sociolinguists use the term. Haugen saw four distinct processes taking place under the heading of linguistic standardisation- a) selection of a variety, usually that of the dominant group, b) codification of form, whereby standard linguistic norms are laid down c) elaboration of function,

\footnotetext{
${ }^{93}$ F. Britto, Diglossia : A Study of Theory with Application to Tamil (Washington, 1986) p.40

${ }^{94}$ Hudson, 'Outline' p.4

95 Sahlins, Boundaries pp.166, 189

${ }^{96}$ P.J. Hélias, Le Cheval d'Orgueil : Mémoires d'un Breton au pays bigouden (Paris, 1975) p.221, cited in Lyons, 'Linguistic Conformity' p.179

${ }^{97}$ E. Haugen, 'Dialect, Language, Nation', in J.B. Pride and J. Holmes (eds.) Sociolinguistics: Selected Readings (Harmondsworth, 1972) pp.97-111; A. Lodge, French, from Dialect to Standard (London, 2001) p.14
} 
whereby a language is adapted for a greater range of social functions, and d) acceptance of the norm by the language community. ${ }^{98}$ The terms adopted by Haugen are not in all respects satisfactory. The distinction between 'selection' and 'acceptance', as Anthony Lodge observes, is rather artificial, for both fundamentally amount to the recognition of a specific set of linguistic norms as the prestige variety to be employed in given communicative functions by a group of speakers. ${ }^{99}$ Similarly, the nature of 'elaboration of function' can at times appear opaque. Haugen defined the term as a linguistic process by which a language gained the tools required for it to fulfil a given social function. However, this places the term in an ambiguous relationship with 'codification'. For example, should one consider the fixing of orthographic and semantic conventions around lexical terms required for a given function, say the practice of law, as codification or elaboration? The idea of standardisation is most useful to the historian when understood as a process involving both linguistic and social change, that is both the codification of the language through grammars, dictionaries, orthographies, and a set of attitudes, beliefs and practices relating to the language and its use.

The significance of this is threefold, firstly that some languages are better equipped in terms of status and codification to fulfil high status communicative functions, secondly that standardised languages are techniques that must be learnt, making their mastery significant for the distribution of social advantage, and finally that the partisans of a given language can seek to further the process in order to improve their own position. This process can be seen in the conflicts over language that characterised the European literary sphere before the Revolution, conflicts that illustrate an important facet of the Napoleonic period, as the expanding borders of the French state brought increased numbers of speakers of standardised languages under the authority of Paris. In France, the sixteenth and seventeenth centuries had seen tremendous efforts on the part of French authors to bestow prestige on the national language at the expense of Latin and Italian through the creation of

\footnotetext{
98 Haugen, 'Dialect, Language, Nation', pp.110-1

99 Lodge, Dialect to Standard p.188
} 
a prestigious writing culture. ${ }^{100}$ The signal text in this movement was probably Du Bellay's $L a$ deffence et illustration de la langue françoyse, published in 1549, in which the author urged patriotic writers to develop the language of the kingdom. ${ }^{101}$ The seventeenth-century apogee of this movement was the creation of the paradigmatic example of state-sponsored prescriptivism, the Académie française. Founded by Richelieu in 1635, Académie was tasked with providing a grammar, dictionary, poetics and rhetoric, in the hope that doing so would enhance the prestige of French on the international stage. ${ }^{102}$ Such efforts would become typical of cultural nationalist movements across Europe in the nineteenth century, for whom the edition of dictionaries and grammars, and the production of literary material such as songs, plays and poetry, was always a high priority, the elaboration of the language representing a powerful way of proving the authentic existence of a nation seeking self-determination. ${ }^{103}$ The Academie française itself was modelled on the Florentine Accademia della Crusca, established in 1582, and prescriptivism in English, typified by Samuel Johnson's 1755 offering, exercised an influence over literate culture every bit as strong as in France despite the lack of state backing. ${ }^{104}$

The notion that a language should be cultivated was neither confined to the turn of the nineteenth century nor the exclusive preserve of French culture, but a widely held concern across Europe from the Renaissance onwards. It was also not the only method used to compare the relative value of languages. Commentators often looked towards the internal properties of a language in order to explain its prominence or justify its preferment. ${ }^{105}$ In the mid-eighteenth century, word order became a particular concern. Thinkers echoing Descartes' strictures that language should follow the natural order of thought, argued that French word order- its subject-verb-object syntax-

\footnotetext{
${ }^{100}$ Brunot, HLF ii, pp.2-3, 80-91

${ }^{101}$ Lodge, Dialect to Standard pp.135-7 ; F.G. Henry, Language, Culture and Hegemony in Modern France (Birmingham Al, 2008) pp.14-8

102 Lodge, Dialect to Standard pp.160-1

103 T. Kamusella, The Politics of Language and Nationalism in Modern Central Europe (Basingstoke, 2009) p.65

${ }^{104}$ A. Elfenbein, Romanticism and the Rise of English (Stanford, 2009) p.14

105 P. Cohen, Courtly French, Learned Latin and Peasant Patois: The Making of a National Language in Early Modern France (Unpublished PhD thesis, Princeton University, 2001) pp.102-3
} 
was the clearest expression of human cognition. ${ }^{106}$ This view was a contested one. Some writers claimed the free word order of Latin permitted the author greater expressive freedom, while partisans of German culture such as Herder pointed to the case system and syntactic inversion in their language as evidence that it could more comfortably represent human thought, which, they claimed, emerged instantaneously more as an image than as the rigid linear chain demanded by French grammar. ${ }^{107}$

All of these arguments were deployed in favour of the pre-eminence of one language or another in 1784, when the Berlin Academy announced that its prize essay competition would be on the universality of the French language. This competition is frequently cited as evidence of the overweening dominance of French as the literate lingua franca of Europe, yet the greater number of responses argued that the language was destined to be replaced by one of its rivals. ${ }^{108}$ The prize was shared between Antoine de Rivarol, whose essay was hugely influential in the characterisation of French as the universal language of Europe, and Johann Christoph Schwab. While the former had much to say on the innate linguistic superiority of French, the latter was far more nuanced in his conclusions. Schwab explored a host of explanations for the apparent superiority of the French language, from geography and demography to economics, although he identified international politics, and the relative strength of the French nation on the continent, as the primary reason. ${ }^{109}$ Consequently, it was entirely plausible that French could be supplanted by another language, and after rejecting Spanish for its geographical isolation, Italian for the peninsula's political fragmentation, and German for its difficulty as a second language, Schwab identified English as the most likely candidate. ${ }^{110}$

\footnotetext{
${ }^{106}$ A. Lifschitz, Language and Enlightenment: The Berlin Debates of the Eighteenth Century (Oxford, 2012) p.32 107 Lifschitz, Language and Enlightenment p.91

$108 \mathrm{~J}$. Storost, Langue française- langue universelle ? Die Diskussion über die Universalität des Französischen and der Berliner Akademie der Wissenschaften (Hamburg, 2008) p.243

${ }^{109}$ Lifschitz, Language and Enlightenment pp.190-1 ; F.G. Henry, 'From the First to the Fifth Republic: Antoine de Rivarol, Johann Christoph Schwab, and the Latest Lingua Franca', The French Review vol.77 no.2 (2003) pp.312-23

${ }^{110}$ Henry, 'From the First to the Fifth Republic', pp.319-22
} 
The various arguments in favour of a given language elaborated from the Renaissance to the Revolution were frequently made either in service of or in reaction to a kind of proto-nationbuilding. The aim was to secure a place within the European society of letters for a given language as the medium of written culture and science. The Berlin Academy itself reflected precisely these conflicts over the establishment of languages within literate culture. The ambitions of Leibniz, the first president of the Academy, to make the institution a forum for the elaboration and improvement of German reflected a more generalised desire amongst German academics to make their language one of learning. ${ }^{111}$ Despite Leibniz' initial intentions, the position of the academy over the eighteenth century was far more ambiguous. The statutes of the Academy allowed for scientific papers in German and Latin, a decision which allowed the latter language to dominate, with German relegated to the position of 'business' language. ${ }^{112}$ Later in the century, the hostility of Frederick the Great to the language saw French displace German as the main language of the Academy. Yet the Academy did eventually come to the aid of German as Leibniz had envisioned. The death of Frederick saw calls for the return of German which only became louder during the Revolutionary period. This eventually saw the creation of groups to purify the German language and, in 1807, the elevation of German to the working language of a reformed Academy. ${ }^{113}$

\section{Culture Brokers and Bureaucrats}

The linguistic imperialism of the Napoleonic regime ensured that arguments of this type abounded within the institutions of the French state. Linguistic practice became suffused with symbolic importance, as nation building became an active concern for political elites, and spheres of linguistic practice- domains such as the Church, the classroom and the law court- were transformed and repurposed. However, if ideas about administrative reform and social improvement were prominent during the period and especially within Napoleonic institutions, to focus only on these

\footnotetext{
111 Lifschitz, Language and Enlightenment pp.44-5

112 Storost, Langue française p. 20

113 Lifschitz, Language and Enlightenment pp.191-2
} 
ideological movements is to paint a misleading picture of state directed centralization and rationalization. ${ }^{114}$ Since my focus is on the role of state building projects in the linguistic integration of the regions, this study is predominantly concerned with the way in which one particular social grouping- a group probably best designated as 'local elites' or 'local notables'- negotiated and indeed constructed the new regime of linguistic practice that emerged from the period. The term notable here does not designate the 'Grands Notables', understood in the manner of André-Jean Tudesq as 'élites dirigeantes'. ${ }^{115}$ It is also intended to incorporate a somewhat broader cross-section than the 'village notables' described by Barnett Singer. ${ }^{116}$ I designate by the term 'local notable' the members of that group of elites who filled the ranks of officialdom, from the level of the commune or municipality up to the departmental or divisional level- the mayor, justice of the peace, schoolmaster, sub-prefect, legal officials up to the level of the appeal court.

These figures were significant because they formed the backbone of the state on the ground. They were the men required to actually implement the linguistic reforms of the Napoleonic regime, and this makes them central to an understanding of Napoleonic cultural imperialism. This very fact placed them at the juncture of centralising state structures and the local society on which it sought to act. They were all to a certain extent defined by their place within the institutional structures of the State, or Church in the case of the clergy, yet they all moved within local society to a greater or lesser extent. Historians such as Lynn Hunt have invoked these 'intermediaries and culture brokers' to explain the tendency towards modernization that characterised Revolutionary politics. ${ }^{117}$ Peter McPhee has criticized the recourse to 'culture brokers' and the 'diffusion theory' of modernization, on the grounds that it fails to explain differences in politicization between areas. This, he suggests, can only be done with reference to the specific social conditions of a given

\footnotetext{
${ }^{114}$ R. Kingston, Bureaucrats and Bourgeois Society: Office Politics and Individual Credit in France, 1789-1848 (Basingstoke, 2012) p.4

${ }^{115}$ A. Tudesq, Les grandes notables en France, 1840-1849 : Étude historique d'une psychologie sociale (Paris, 1964) i, pp.7-10

116 Singer, Village Notables p.1

${ }^{117}$ L. Hunt, Politics, Culture and Class in the French Revolution (London, 2004) pp.205-6
} 
locality. ${ }^{118}$ In the case of local state elites, however, the term 'culture brokers' is apt, because of the institutional structures that placed them quite explicitly in an intermediary position, and because the metaphor of brokerage is a useful one. These figures did not simply translate the state to the locality, they translated the local for the centre, their local knowledge became an important feature of their expertise, and so the idea of brokerage (or indeed translation) becomes descriptively useful. The term also points away from a vision of a top down, monolithic state imposing its will upon local society, because the linguistic practice as implemented, and argued for, by these figures often moderated the demands of the centre and reshaped the nature of state power on the ground.

At first glance, this may appear a heterogeneous grouping. To take just the example of the mayor, there is a clear distinction to be drawn between the 'village' mayors, appointed by the prefect, and those mayors of settlements with a population exceeding 5000 in size, who were appointed directly by Napoleon. Moreover, the prefect-appointed mayors of smaller communes were themselves a diverse grouping. ${ }^{119}$ These mayors were appointed hurriedly in 1799 largely by prefects unfamiliar with their departments, and as a result were predominantly recruited on the basis of their service during the Revolution. Consequently, these figures became a constant headache for the administration, notorious for their unreliability and illiteracy. ${ }^{120}$ Yet even here, generalisations can be misleading. A substantial number of individuals who had, under the Ancien régime, filled the upper echelons of the regional administration, took up local administrative roles during the period as they retreated from public life to their family holdings during the Revolutionary decade. Over 12000 'administrateurs locales inférieures'- defined by Louis Bergeron and Guy Chaussinand-Nogaret as municipal officials- were to be found amongst the most heavily taxed five hundred individuals of their respective departments, although few enjoyed genuinely substantial

\footnotetext{
${ }^{118}$ P. McPhee, 'Historians, Germans and Culture Brokers: the Circulation of Ideas in the Nineteenth Century French Countryside', Australian Journal of French Studies vol.23 no.3 (1986) pp.121-5 119 Woloch, New Regime pp.127-33

120 J. Dunne, 'Napoleon's Mayoral Problem: Aspects of State Community Relations in Post-Revolutionary France', Modern and Contemporary France vol.8 no.4 (2000) pp.481-4
} 
wealth. ${ }^{121}$ This was probably a function of changing recruitment. Many of the mayors appointed in 1800 , for example, were purged when their terms expired in 1808, and a focus on wealthier land owning rural dwellers as well as an emphasis on the lumières of candidates, transformed the social profile of this office in the countryside. ${ }^{122}$ Large numbers of mayors may have been illiterate, impoverished, or otherwise unsatisfactory by the lights of the state, but they were not universally so, and their profile changed over the period.

The internal heterogeneity of these office holding categories was matched by the differences evident between groups of office holders, especially since these groups experienced very different Revolutions. The clergy, for example, provide a striking contrast with the lower ranks of the local administration. Only 822 clergymen were to be found amidst the most heavily taxed of the Empire, a fraction of the number of local administrators, a reflection of the decimation of the wealthy higher clergy during the Revolution. ${ }^{123}$ Yet while the clergy as a collective enjoyed less wealth than officers of the local administration, their professional formation more or less guaranteed a high degree of functional literacy and, within most of multilingual old France, a knowledge of both Latin and French. Schoolmasters, secondary school teachers, legal officials- all could be distinguished by the specific institutional structures that served to define their social functions, and these specificities will be dealt with in the relevant chapters of this study.

The geopolitical history of the Napoleonic Empire was also a crucial part of the context in which these figures operated. This cannot be reduced to a simple distinction between 'Old' France and the 'occupied' France of the départements réunis. Here the concept of the 'inner' and 'outer' empire developed by Michael Broers is an indispensable starting point, demonstrating that the Napoleonic state was able to take root in certain areas recently conquered by French armsespecially those annexed before 1808 such as parts of Northern Italy and the Rhineland- while even

\footnotetext{
${ }^{121}$ L. Bergeron and G. Chaussinand-Nogaret, Les masses de granit: Cent mille notables du premier empire (Paris, 1979) p.43 ; Woloch, New Regime p.129

122 Dunne, 'Napoleon's Mayoral Problem' pp.486-8

${ }^{123}$ Bergeron and Chaussinand-Nogaret, Les masses de granit $\mathrm{p} .43$
} 
maintaining law and order proved a challenge in the Vendée and parts of the Midi, areas incorporated, if not necessarily integrated, into the French state centuries earlier. ${ }^{124}$ The linguistic geography of the Empire, as will become clear, was also significant, and it also meshed awkwardly with older political geographies of Europe. Some areas annexed, such as Francophone Belgium, can easily be contrasted with places such as Lower Brittany or Northern Catalonia, where large swathes of the population spoke no French, although here at least there was a history of French as language of state and high literature, not something found outside the highest social strata in places otherwise apparently well integrated into the Empire such as Milan or Saarbrüken.

The study is divided broadly into two sections. In the first section, I discuss the classificatory systems available to speakers and the discursive options available to them within different contexts. The attitudes of speakers is examined primarily through the production of ethnographic data of the type the regime was famed for; the descriptive statistics orchestrated by the Bureau de la statistique and drafted in the departments by prefects, administrators and local scholars. ${ }^{125}$ The first chapter is concerned with the production of knowledge about society during the Revolutionary and Napoleonic period, specifically with the tradition of descriptive statistics that emerged during the period. The administrative gaze of the officials who authored these descriptions of the territories and populations they governed served to construct social and cultural practice, including language, as an object of state action. The intention was to create a synchronic picture of society at the start of the new regime which would serve to illustrate the social progress engendered by the actions of the state.

These departmental statistics frequently cited language as an object of reform, and with the enquiry into the languages of the Empire, conducted between 1806 and 1812 by the head of the

\footnotetext{
${ }^{124}$ Broers, Europe Under Napoleon, M. Broers, 'Napoleon, Charlemagne and Lotharingia: Acculturation and the Boundaries of Napoleonic Europe', The Historical Journal vol.44 (2001) pp.135-154

125 On the descriptive statistics see M.N. Bourguet, Déchiffrer la France: la statistique départementale à l'époque napoléonienne (Paris, 1989) ; J.C. Perrot, L'âge d'or de la statistique régionale (Paris, 1977) ; J.-C. Perrot and S.J. Woolf, State and Statistics in France, 1789-1815 (London, 1984)
} 
Bureau de la statistique Charles-Etienne Coquebert de Montbret, and his son Etienne, who was also an official at the Bureau, language was placed firmly under the administrative gaze. This enquiry, which emerged from the tradition of descriptive statistics, revealed the tensions implicit in the production of social knowledge. The descriptive statistics were drafted or overseen by prefects, who drew on knowledge they gleaned from their own correspondence with local administrators and tours of the department. The enquiry carried out by the Coqueberts, in contrast, preserves a series of direct exchanges between the centre and the kinds of local state notables described above from which telling divergences in the classification and status of local knowledge forms like language emerge.

The next chapter, on the material generated by the Coqueberts focuses on divergent visions of the relationship between language and space. It is argued that while the Coqueberts sought to understand linguistic diversity in terms of territory and space, their correspondents tended to associate different styles of speaking with place, reflecting how firmly rooted in the local the social imaginary of these figures was. This in turn reveals an important distinction between types of geographical knowledge. On the one hand, administrators such as the Coqueberts were focused on territory, on geographical space as it is administered by the state. ${ }^{126}$ In contrast to this, many of their correspondents thought in terms of a situated sense of place, of geography as something experienced and lived through the interactions of local communities. It is argued that, rather than understanding linguistic difference in relation to the proto-philological distinctions of linguistic territory drawn by the Coqueberts, they viewed language through the prism of local rivalries.

The following chapter concerns the social use of dialects, demonstrating that diglossia was a central feature of linguistic practice, transcending both the linguistic boundaries between the Langues d'oc and the Langues d'oil fetishized by the Coqueberts, and the political boundaries of prerevolutionary France. However, the diglossic situation revealed by the work of the Coqueberts,

${ }^{126}$ D. Nordman Frontières de France: De l'espace au territoire, XVIe-XIXe siècle (Paris, 1998) p.486 
substantiated by the work of later folklorists, demonstrates how the value of French as an ' $\mathrm{H}$ ' language was not confined to the political structures of the French state, but grounded in the everyday linguistic practice of communities.

Having shown the diglossic practices that pertained across much of France, the final chapter on the Coqueberts' enquiry is concerned with the attitudes of contemporaries towards their own linguistic diversity. Focusing on how local notables, themselves often bilingual, understood their own linguistic diversity and sought to represent it to the centre reveals not only the stigma that could be attached to speakers of local dialects, but the effort to construct the local language as linguistic patrimony, as a form of local knowledge in which, as native speakers, those writing to the Coqueberts might be considered experts.

In the second half of this thesis I focus on how the nature of the linguistic diversity of the French population, as well as the attitudes of local notables towards language influenced the elaboration of linguistic practice within three crucial social institutions- the school, the law court and the Church. In all three of these institutions, the dynamic between local and official forms of knowledge, outlined in the first half of the study, becomes centred on the question of how far practice should accommodate local culture, or conversely seek to impose homogeneity on local communities. An examination of school inspector reports from the Napoleonic period shows how, in keeping with educational projects elaborated during the Revolution, the schoolroom was considered a crucial site for the dissemination of the national language. However, a detailed examination of the primary schooling in the Alpes-Maritimes shows how, despite the efforts of the prefect, French was not always able to dominate Italian in the classrooms of the department. This was not simply a case of the local trumping the centre. Rather, as the distribution of linguistic practice in the primary schools of the department shows, the crucial factor was the position of French or Italian as the $\mathrm{H}$ form, in which local elites and schoolteachers had invested and to which they consequently remained loyal. 
At the start of the Napoleonic period, the law courts of the empire, the focus of the next chapter, were similarly understood as a mechanism for the standardisation and homogenization of society. The Napoleonic Empire retained a commitment to legal universalism, and as such a common legal procedure, carried out in a common language, was deemed both central to the Napoleonic project and a means by which local legal officials might be encouraged to learn French. However, as demonstrated by the recruitment of judges and the testimony of legal officials themselves, this aim was often in conflict with the effective administration of justice. As a result, informal accommodations, and eventually official provisions, for the use of other languages were introduced.

The Church, the subject of the final chapter of the thesis, is generally understood as an opponent of centralising and modernizing projects, cleaving to traditional cultural forms and local languages as a means to insulate the population from secularizing trends. However, an examination of the Church during the Napoleonic period reveals an institution riven by exactly the same uncertainties and debates as the education and legal systems. While commentators focusing on the Third Republic have understood the Church as an essentially reactionary force, an impulse towards the regulation of cultural practice, particularly of popular religious forms, had long influenced pastoral work. The linguistic character of religious practice across France was a patchwork, in some places making use of the national language for worship alongside Latin while regional languages dominated in others. However, the tendency of the Church hierarchy towards social pedagogy is revealed in the seminary regulations of the Napoleonic period, which invariably sought to familiarise the next generation of priests with French. It was only with the fall of Napoleon and the reChristianisation campaigns under the restored Bourbon monarchy that the 'mother tongue' came to be understood as a means of saving souls, and only then within the frequently controversial circles of missionaries.

The striking thing about these arguments over linguistic practice is the way in which local officials mobilized notions of linguistic and cultural particularism to justify departures from what 
otherwise might be considered desirable by the regime. The normative orientation, the position taking, of the local notability in relation to linguistic diversity had a discernible impact on the linguistic forms of the state. The central problem here is to historicize the rhetoric of modernization that emerges from the source material, to understand modernity not as a check-list of conditions that arise through an often unspecified historical process, but, much as with state power, as a conscious mind-set or set of choices, as a normative orientation to the features of social life. ${ }^{127}$ Modernity, as the anthropologist Sharon MacDonald reminds us, is a heterogeneous and ambivalent experience, and one which sees social practices constituted and legitimized as 'traditions' and 'heritages' as frequently as they are denounced, restricted or reformed. ${ }^{128}$

127 C.A. Bayly The Birth of the Modern World, 1790-1914: Global Connections and Comparisons (Oxford, 2004) p.10

${ }^{128}$ S. Macdonald Reimagining Culture: Histories, Identities and the Gaelic Renaissance (Oxford, 1997) p.4 


\section{Language under the Administrative Gaze: State, Statistics and Social Knowledge under Napoleon}

The Napoleonic period witnessed a flourishing of efforts to produce knowledge about society. The enlightened gaze of administrators and amateur scholars was turned towards the territory and population of the Empire in an effort to describe not only the economic situation but also the social and cultural practices of inhabitants. The period saw a concerted effort to make society 'legible' in James C. Scott's terminology. ${ }^{129}$ Some efforts aimed at the collection of information about society were directly related to the material concerns of the state or of the management of society. The Napoleonic cadastre, for example, was intended to make tax collection more efficient, while population figures allowed quotas for conscription to be drawn up. ${ }^{130}$ The centrepiece of this effervescence of social description, the departmental statistics, went beyond the collation of numbers in relation to population and production, and sought to describe local social practices. The production of these descriptive statistical tracts was inextricably linked to the French state, since they were commissioned by the Bureau de la statistique, which was part of the Ministry of the Interior. As Marie-Noëlle Bourguet has argued, these descriptive statistics became increasingly ethnographic in character. ${ }^{131}$ This reflected the increasing interest in descriptions of the social and cultural practices of the French population manifested in the work of the Académie celtique, an organisation which itself had links to the French state, as well as the descriptive travelogues produced during the period. ${ }^{132}$

A common characteristic of all these efforts was the process of observation. This involved not just description, but the imposition of an analytical grid on society, a scheme of questions that constituted a technology of seeing and which governed the production of knowledge. It also involved a form of geographical displacement from centre to periphery, either in the form of the observers themselves, be they metropolitan travellers or administrators, or of information through

\footnotetext{
${ }^{129}$ Scott, Seeing Like a State p.11

${ }^{130}$ R.J.P. Kain and E. Baigent, The Cadastral Map in the Service of the State: A History of Property Mapping (London, 1992) pp.228-31

131 Bourguet, Déchiffrer p.79

${ }^{132}$ N. Belmont, Aux origines de l'ethnographie française: L'académie celtique (1804-1812) (Paris, 1995)
} 
administrative or scholarly correspondence. This process created a vision of society at the centre that could then be exported back down to the region. This was significant because, as this chapter will argue, the vision implied a course of action; it constructed local society as just that- a particularity, and valorised the notion of progress and homogeneity.

As the period went on, language featured with increasing prominence in these descriptions of society. The way in which the population communicated became an object of enquiry for the administrators who compiled the departmental statistics and in turn the integration and modernization of the population of the Empire was understood to involve the spread of the French language. This interest reached its highpoint with the enquiry into the languages of the Empire, conducted by the Bureau de la statistique between 1806 and 1812 under the impulsion of its then chief, Charles-Etienne Coquebert de Montbret and his son Eugène. As the following chapters will show, this enquiry revealed many of the ambiguities that arose from this process of producing knowledge about society. This chapter will situate this effort to describe the linguistic practices of society in the broader production of social knowledge during the period, and especially the state directed departmental statistics. It will begin with a description of the techniques employed in the description of society during the period before moving on to their ideological use in constructing society as an object of state action. Finally the place of language in these enquiries will be examined.

\section{The Production of Social Knowledge under Napoleon}

The statistical enquiry as practised during the Directory and Empire was not new. It owed a great deal to the statistical treatises of administrators during the Ancien régime, and to the enquiries of the intendants carried out under Louis XIV. ${ }^{133}$ These studies were generally little concerned with society, focusing instead on the immediate concerns of the monarchy such as taxation and

${ }^{133}$ Bourguet, Déchiffrer pp.25-6 
agricultural production. ${ }^{134}$ In the second half of the eighteenth century, the scope and audience of such descriptive practices were transformed.

Until the last decades of the eighteenth century, statistics had been the secret of the state. A crucial turning point, according to Bourguet, was the 1781 publication by Louis XVI's Finance Minister, Jacques Necker, of his famous Compte rendu de l'état du royaume et des affaires publiques. ${ }^{135}$ Necker's work was not the first account of the royal finances to be published before the Revolution, but its large circulation placed the administrative knowledge of the state prominently within the public sphere. ${ }^{136}$ The new impulse towards publicity in state affairs continued into the Napoleonic period, manifest in the annual Exposé de la situation de l'Empire, presented to the legislative corps by the Minister of the Interior. Earlier iterations of these exposés amounted to little more than a justification of Government policy over the preceding year, and the benevolent impact of the Napoleonic state upon society was simply asserted. In 1804, for example, it was claimed that the encouragement of the government was leading to the improvement of agriculture and to the introduction of improved breeds of livestock, while the return of peace and civil order brought about by the Napoleonic regime encouraged charity and thus the diminution of the number of vagrants. ${ }^{137}$ The regime, in other words, sought to claim legitimacy on the basis of social progress, upon the improvement of society. The Exposé was transformed in the final years of the regime by Jean-Pierre de Montalivet, who was appointed Minister of the Interior in 1809. Montalivet sought not only to assert the progress brought about by government activity but to substantiate it with reference to statistics on population, agricultural production, commerce and public spending on improvements such as roads and bridges. ${ }^{138}$ In each of these categories, 1789 was taken as the starting point and

\footnotetext{
${ }^{134}$ Bourguet, Déchiffrer pp.26-31

135 Ibid., p. 33 ; J. Necker Compte rendu au Roi (Paris, 1781)

${ }^{136}$ For a reappraisal of Necker's work see J. Félix, 'The Problems with Necker's Compte Rendu au Roi (1781)', J. Swann and J. Félix (eds.), The Crisis of the Absolute Monarchy: From the Old Regime to the French Revolution (Oxford, 2013) pp.107-125

${ }^{137}$ Exposé de la situation de l'Empire française, 10 nivôse an XIII (Paris, 1806) pp.13-14

${ }^{138}$ Perrot and Woolf, State and Statistics pp.143-7
} 
the aim was to demonstrate how the new regime had improved the country by increasing the level of population or agricultural production. ${ }^{139}$

The new emphasis on the public exercise of government authority was joined by an increasing desire to describe the social and cultural practices of the population. This was manifested most obviously in the enlightened travelogues, the observations of doctors eager to improve hygiene, and the work of local learned societies. ${ }^{140}$ This ethnographic interest in the lives of the rural population of France became particularly marked in the travel writing of the 1780 s. The enlightened travelogue as a genre had focused predominantly on urban life up to this point, but with publications such as Le Grand d'Aussy's Voyage dans l'Auvergne, a new desire to seek out the 'savage' parts of France, to describe and account for the practices of the French peasantry, came to prominence. ${ }^{141}$ This ethnographic impulse profoundly marked the production of social knowledge during the Napoleonic period, including a number of volumes of the departmental statistics and the enquiry of the Coqueberts into the languages of France. ${ }^{142}$

This pre-Revolutionary ethnographic interest took some time to imprint itself on the official production of social knowledge in the form of the departmental statistics that took shape under a succession of interior ministers. Based on the genesis of the genre as described by Marie-Noëlle Bourguet we might distinguish a number of different types of source. Departmental statistical enquiries were originally conceived during the Revolution with the division of the regions into departments. The earliest enquiries on the departmental level were aimed at grasping the territorial extent of regions to facilitate the setting of tax levels. The outbreak of war and the levée en masse brought about an increased interest in population levels and in the distribution of resources that might be requisitioned. However, it was only with the arrival of François de Neufchâteau at the

139 J.P. Montalivet, Exposé de la situation de l'Empire présenté au corps législatif, dans sa séance du 25 Février 1813 (Paris, 1813) p.3 ${ }^{140}$ Bourguet, Déchiffrer pp.36-46

${ }^{141} \mathrm{~A}$. Burguière, 'Monarchical Centralization and the Birth of Social Sciences: Voyagers and Statisticians in Search of France at the End of the Eighteenth Century', R. M. Schwartz and R. A. Schneider (eds.) Tocqueville and Beyond: Essays on the Old Regime in honour of David D. Bien (London, 2003) pp.227-9

${ }^{142}$ Burguière, 'Monarchical Centralization', p.226 
Ministry of the Interior that the widespread composition of statistical surveys at the departmental level began. His circular of the 26 germinal year VII (15 ${ }^{\text {th }}$ April 1799) called for the compilation of descriptions abrégées of the departments of the Republic. ${ }^{143}$ Lucien Bonaparte, following his installation as Minister of the Interior in place of François de Neufchâteau after the coup d'état of the $18^{\text {th }}$ Brumaire, issued a new set of questions to guide the compilation of departmental statistics, although his greatest contribution established the Bureau de la statistique to archive and coordinate the fruits of this descriptive effort. ${ }^{144}$

Up to this point the departmental statistics, the Descriptions abrégees composed according to the directives of François de Neufchâteau tended to be fairly unambitious texts. Many of these publications, such as the Description abrégée du département du l'Aube, which appeared in September 1799 , totalled only twenty pages. ${ }^{145}$ Even the longer works, such as the Description abrégée du département du Gard were no longer than eighty pages. ${ }^{146}$ They were largely confined to a simple topography of the department followed by an account of the agricultural, commercial and industrial activity taking place in the region and perhaps a few paragraphs on the mours of the population. This changed in 1801, with the intervention of yet another minister of the interior, JeanAntoine Chaptal. His circular of the $19^{\text {th }}$ Germinal year IX. (9 $9^{\text {th }}$ April 1801) gave a new structure to the departmental statistics, with five chapters; 1) a topographical description, 2) a detailed breakdown of the population by age, sex and marital status, 3) a description of state of society, 4) agricultural production and 5) industrial and commercial activity. ${ }^{147}$ These statistical descriptions were substantially more detailed than the preceding Descriptions abrégées. The third chapter in particular, describing the state of the population of a given department, marked a broadening of the scope of the enquiry. The details of social customs and practices, of hygiene, education, literacy criminality and of the character of the inhabitants of a department were now scrutinized by

\footnotetext{
143 Bourguet, Déchiffrer pp.54-64

144 Ibid., pp.65, 101-2

145 Descolins, Liberté égalité : Description abrégée du département du l'Aube (Troyes, an VII)

146 S.V. Grangent, Description abrégée du département du Gard (Nîmes, an VIII)

${ }^{147}$ Bourguet, Déchiffrer p.68
} 
administrators. The Mémoire statistique published in the year XI by the prefect of the Moselle was 200 pages long and contained a lengthy description of the charity, criminality and literacy of the population which concluded with remarks on religion and language. ${ }^{148}$

The departmental statistics compiled and published through the Ministry of the Interior were joined by a host of local publications, many of which were also the product of individuals involved with the local prefecture. These works generally took the form of an Annuaire statistique, containing information on local market days, weights and measures and office holders in addition to a statistical description of the department. The description itself, however, generally conformed to the pattern laid down at the centre. The 1807 Annuaire statistique for the Hautes Pyrénées, for example, was simply a revised version of the 1801 departmental survey submitted to the Minister of the Interior. ${ }^{149}$ The Tableau statistique du département de la Dyle adopted a different format, presenting information in the form of a table rather than a text, yet the logic of the enquiry remained, with population broken down by geographical locale and a short series of observations on the language and customs of the region included at the end of a 'précis statistique'. ${ }^{150}$

The prefecture was a pivotal site in the compilation of the departmental statistics. Most descriptions, like the work of Colchen on the Moselle, were composed under the direction of the prefect. The majority of the rest were delegated to the Secrétaire de la Préfecture, as was the case with the accounts published on the departments of the Nord, Vendée, Dordogne, and Lot-etGaronne. ${ }^{151}$ Occasionally a local scholar or other official would be chosen to complete the work. The Annuaire statistique of the Seine-Inférieure was written by Vitalis, a professor at the Lycée, while the

\footnotetext{
148 J.V. Colchen, Mémoire statistique du département de la Moselle (Paris, an XI) pp.90-114

149 P. Laboulinière, Annuaire statistique du département des Hautes-Pyrénées (Tarbes, 1807) p.2

${ }^{150}$ M.D.B., Tableau statistique du département de la Dyle, divisé en trois arrondissements communaux ou souspréfectures (Brussels, an XIII)

${ }^{151}$ C. Dieudonné, Statistique du département du Nord (Douai, an XII) ; G. Delfau, Annuaire du département de la Dordogne (Périgueux, an XII) ; C.M. Lafont du Cujula, Annuaire ou description statistique du département du Lot-et-Garonne, rédigé d'après les instructions de S.E. le ministre de l'Intérieur (Agen, 1806) ; P.L.C. Labretonniere, Statistique du département de la Vendée (Paris, an IX)
} 
engineer in chief of the Gard was responsible for the Description abrégée of his department. ${ }^{152}$ While a figure in the prefecture directed the project, the statistic was always in part a collaborative endeavour. The individual compiling the statistical description of the department would always lean on the knowledge and expertise of local figures. Often this meant carrying out a correspondence with the mayors within the department, asking them to respond to questionnaires and provide information. As Dalphonse, prefect of the Indre, explained, 'j'ai mis à la portée de tous les maires, toutes les questions relatives à la Statistique. J'ai reçu toutes leurs réponses ; je les ai toutes comparées entre elles'. ${ }^{153}$ The clearest evidence of this practice is to be found in the correspondance of Christophe de Villeneuve, the prefect of the Bouches du Rhône under the Restored Bourbons who published a multivolume statistical description of the department in the $1820 \mathrm{~s}^{154}$ In writing this work, Villeneuve carried out an extensive correspondence with the mayors of his department, distributing questionnaires on topics such as the practice of village festivals, the etymologies of place names and the historical monuments of the region. ${ }^{155}$

Information not obtained through correspondence was collected through direct observation. Where the author was the prefect this would generally take place during the annual administrative tour of the department, a journey undertaken primarily to oversee administrative activities such as conscription. Dalphonse, for example, describes how intensive travelling across his department allowed him to complete his survey; 'pendant quatre mois consécutifs, j'ai parcouru le département de l'Indre ; j'ai visité toutes ses communes, tous ses établissements, toutes ses routes : par tout j'ai vu, j'ai interrogé, j'ai recueilli'. ${ }^{156}$ The practice of statistical description was, therefore, closely related to the enlightened travelogue. Some of the best known travelogues of the Napoleonic period began as administrative voyages. One such example is Jacques Cambry's Voyage dans le Finistère,

\footnotetext{
152 J.B. Vitalis, Annuaire statistique du département de la Seine-Inférieure (Rouen, an XII) ; Grangent Gard

${ }^{153}$ F.J.B. Dalphonse, Statistique générale de la France, département de l'Indre (Paris, an XII) p.2

${ }^{154}$ C. de Villeneuve, Statistique du département des Bouches-du-Rhône (4 vols, Marseille, 1821, 1824, 1826, 1829)

${ }^{155}$ AdBdR 6 M 1601-1605 (Statistique Villeneuve, monographies communales)

${ }^{156}$ Dalphonse, Indre p.2
} 
published in $1799 .{ }^{157}$ Cambry was a government administrator, fulfilling various roles during the Revolution before serving as prefect of the Oise between 1800 and 1802. During his time as prefect, Cambry authored a two volume Description of the Oise, a work fitting neatly into the Napoleonic practice of departmental statistical description. ${ }^{158}$ His better known Voyage dans le Finistère underscores the porous nature of distinctions between administrative description and enlightened travelogue. Cambry's Voyage was initially undertaken as a survey of surviving monuments and artworks in the department following the vandalism of the Terror. ${ }^{159}$ When it reappeared in 1799 as the Voyage the work was suffused with the romanticised celtomania that would later permeate the work of the Académie celtique, and his descriptions of the Breton coast were influential as sublime treatments of the landscape of the kind that would later be found in the writings of Chateaubriand, amongst others. ${ }^{160}$ Yet contemporaries also understood Cambry's Voyage as a contribution to the production of statistical knowledge. The reviewer of this 'useful book' in the Décade Philosophique, having lamented the impoverished state of France's interior, claimed that 's'il existait un travail semblable sur toutes les autres départemens [...] on pourrait regarder le grand ouvrage de I'amélioration intérieure comme déjà considérablement avancé'. ${ }^{161}$

Travel writing and statistical description were, therefore, understood by contemporaries as closely related activities, and this relationship was manifested in a common epistemology centred on the practice of enlightened observation. It was enlightened observation that allowed the production and distribution of social knowledge, by providing a grid through which accounts of society could be structured. The paradigmatic form of enlightened observation under Napoleon was the questionnaire. The statistiques départementales were themselves structured by the questionnaires

\footnotetext{
157 J. Cambry, Voyage dans le Finistère (Paris, 2000)

158 J. Bernet, 'Jacques Cambry, premier préfet de l'Oise (mars 1800- avril 1802) et sa Description du département de l'Oise (1803), ouvrage précurseur sur l'ethnologie du département', in A. de Mathan (ed.), Jacques Cambry, un Breton des Lumières au service de la construction nationale (Brest, 2008) p.90 159 J. Cambry, Catalogue des objets échappés au vandalisme dans la Finistère: dressé en l'an III (Rennes, 1889) ${ }^{160}$ A. Corbin, The Lure of the Sea: The Discovery of the Seaside in the Western World, 1750-1840 (London, 1995) pp.135-7

161 'Voyages- Administration', in La décade philosophique, littéraire et politique A.8 t.24 (1800) p.463
} 
of François de Neufchâteau and Chaptal, which determined the features of society to be described. ${ }^{162}$ The questionnaire became a ubiquitous feature of scholarly, as well as administrative, attempts to describe society during the period. The publication in 1800 of Joseph-Marie Degerando's Considérations sur les diverses méthodes à suivre dans l'observation des peuples sauvages, which contained a series of questions about the beliefs and practices of inhabitants of the New World intended to structure the work of enlightened explorers, is often cited as an early cornerstone of anthropology ${ }^{163}$ The popular customs and practices of the French population were the object of the questionnaire compiled by the Académie celtique and circulated to the provincial scholars and administrators who formed the membership of the Académie. ${ }^{164}$ The questionnaire was even distributed through the state bureaucracy in the Kingdom of Italy. ${ }^{165}$ Towards the end of the period, Volney made the connections between the observations of enlightened travellers and the administrative statistics of the Napoleonic state explicit with the publication of his Questions de statistique à l'usage des voyageurs. ${ }^{166}$ Volney's list of 135 questions for the traveller to answer about each location he visited clearly demonstrates the observational practice of the period. The topics mirrored the statistiques départementales, opening with geographical information such as latitude and longitude before broadening out to examine agricultural and industrial production, population and even cultural practices like reading groups. ${ }^{167}$

The questionnaire, therefore, was intended to structure the practices of enlightened observation across a range of activity, from the descriptive statistics of the prefects and Ministry of the Interior to the writings of travellers and antiquarians interested in popular culture.

Questionnaires could be disseminated either through correspondence or through the personal

\footnotetext{
162 Bourguet, Déchiffrer pp.63-8

163 J.M. Degerando, The Observation of Savage Peoples F.C.T. Moore (trans.) (London, 2004)

164 'Série de questions', in Mémoires de l'Académie celtique vol.1 no.1 (1807) pp.72-86 ; see also, M. Ozouf, L'école de la France, essais sur la Révolution l'utopie et l'enseignement (Paris, 1984) p.356

${ }^{165} \mathrm{G}$. Tassoni, Arti e tradizioni popolari: Le inchieste napoleoniche sui costumi e le tradizioni nel regno italico (Bellinzona, 1973)

${ }^{166}$ C.F. Volney, Questions de statistique à l'usage des voyageurs (Paris, 1813)

${ }^{167}$ Volney Questions p.20
} 
movement of the observer, and were the central technology in the production of knowledge about society during the period. They were above all a technology of seeing that allowed common techniques of observation to be implemented across the Empire and even beyond. The questionnaire shaped the enlightened gaze of administrators and scholars, producing a standardized form of knowledge that could be transmitted back to the centre where it could be arranged as a coherent and public vision of society.

\section{Social Knowledge and Social Improvement}

The paradoxical effect of this very public attempt to describe society, carried out to a significant extent by state actors, was to establish the state as something acting upon society from the outside. It served at once as a diagnosis of society, a way of identifying ills to be cured, and at the same time as a legitimation of state power. This ideological justification of the authority of the state, and particularly the post-revolutionary state, was a central feature of the statistiques départementales as conceived by Chaptal. As with Montalivet's Exposé, the aim was to document the condition of the country as a whole and compare it with 1789 in order to assess the impact of the regime's policies. The legitimacy of the regime was thus tied to the idea of social progress and improvement. ${ }^{168}$ This tendency was particularly marked in the départements réunis. The prefect of the Rhin et Moselle was particularly sensitive to the comparison of conditions before the Revolution with the situation under French rule. He confessed that literacy rates had fallen since the arrival of French troops, and that the occupation had 'démoralisé' the country. ${ }^{169}$ Yet he was certain that the benevolent impact of French governance was making itself felt. In Koblenz, he claimed, prosperity was beginning to flourish because 'le Gouvernement et le génie de la France la réveillent'. ${ }^{170}$ Perhaps the most notable benefit of French rule, however, was the banishment of superstitions and archaic customs. As the prefect wrote :

\footnotetext{
168 Bourguet, Dechiffrer p.73

169 J.B. Boucqueau, Statistique générale de la France : Mémoire statistique du département de Rhin-et-Moselle (Paris, an XII) pp.82, 123

${ }^{170}$ Boucqueau, Rhin-et-Moselle p.32
} 
Si la révolution, le passage et le séjour des armées ont démoralisé ce département, comme on les en accuse, ils ont au moins puissamment contribué à en bannir un grand nombre de superstitions dont les habitans étoient victimes, et à y rappeler des idées religieuses et politiques plus simples et plus sages. ${ }^{171}$

Thus, according to the prefect, tales of ghosts, spirits and exorcisms, the 'charlatanism' that impeded progress in agriculture, were swept away by the arms of French reason. The French state, in this formulation, was a tool for the enlightenment and improvement of society.

This justification for state authority was closely related to the practice of 'diagnosing' society as it emerged from Napoleonic social description. Commentators used clinical metaphors such as 'diagnosis' and 'cure' during the period. As the reviewer of Jacques Cambry's Voyage in the Décade philosophique wrote, in praising his descriptions of popular customs, 'pour guérir il faut connaître'. ${ }^{172}$ In common with the statistiques départementales, Cambry identified projects and improvements requiring the support of the state. As Sharif Gemie observes, 'every second page' saw Cambry bemoan the lack of some public facility. ${ }^{173}$ The diagnosis of Breton 'backwardness' served to legitimate state action on society; it was the necessary first step towards 'amelioration'. As Cambry claimed, ' $j$ 'indique les besoins de ces bons paysans [...] Les contrées voisines de Paris obtiennent tout, parce qu'elles ont des avocats auprès du gouvernement'. ${ }^{174}$

As with the prefect of the Rhin et Moselle celebrating the decline of superstition as a product of French rule, so Cambry's statements on the 'absurdities' of peasant 'superstitions' demonstrate how the impulse towards improvement manifested as a desire to censor and regulate cultural practices. According to Cambry, the population of lower Brittany was notable for its superstitions; 'quelques absurdités particulières caractérisent chaque canton de l'univers; la Bretagne les réunit toutes. ${ }^{175}$ Cambry therefore would seem to embrace those two objects, social

\footnotetext{
${ }^{171}$ Boucqueau, Rhin-et-Moselle p.82

172 'Voyages- Administration' in Décade philosophique p.463

${ }^{173}$ S. Gemie, Brittany 1750-1950, the Invisible Nation (Cardiff, 2007) p.86-7

${ }^{174}$ Cambry, Voyage p.120

175 Ibid., p80
} 
science and education, regarded as 'a panacea against despotism' ${ }^{176}$ The 'absurdities' of 'popular' culture, arose out of 'ignorance', from a lack of education, as we see in the district of Morlaix where 'l'éducation des enfans est négligée, abandonnée totalement,' and as a result 'tous les préjugés se professent dans les boutiques: les bonnes racontent encore des histoires de ravenans, des miracles; chargent d'erreurs le cerveau des enfants. ${ }^{177}$ It is ignorance that the government must combat, and these 'absurdities' would have to be reformed by the new regime if it were it to avoid 'despotism' and ameliorate social problems; 'le plus détestable des gouvernemens est celui qu'on établit sur la sottise. En dernière analyse l'ignorance est le plus grand des maux, et la source de tous les crimes' ${ }^{178}$ In Cambry's account, Brittany existed in a state of backwardness equal to the most isolated reaches of the word, and its inhabitants suffered comparable hardships:

Quand vous avez lu, dans les récits des voyageurs, la description de la vie malheureuse des habitans de la Terre-de-Feu, des infortunés qui végètent sur les rochers de la mer du Sud, des malheureux Lapons ensevelis sous la neige, du Kamstchhadal nourri de poissons corrompus; vous vous êtes quelquefois écriés: O France! Trop heureux qui naquit dans ton sein, sur cette terre si féconde. [...] Vous ignorez quel est, dans cette même France, l'état, la vie, des habitans de Pontusval, et de la côte de la Bretagne en général. ${ }^{179}$

However, it was to despotism and ignorance that this backwardness should be attributed. Cambry railed, for example, against the inadequate dress favoured by the peasantry, 'qui ne couvrent que la moitié des fesses,' and which:

fut inventé sous le gouvernement féodal, par des seigneurs impérieux, intéressés à les contenir, à les comprimer toute espèce d'élans, à les mettre hors d'état de résister. [...] C'est ce principe, dit-on, qui força les femmes de la Chine à ne porter que des petits souliers; les conceptions de la tyrannie sont les mêmes sur tout la terre. ${ }^{180}$

Cambry thus interpreted cultural diversity as evidence of feudal abuses, the 'irrational' and impractical clothing springing logically from the unmitigated dominion of 'tyranny'.

\footnotetext{
${ }^{176}$ A.G. Sepinwall, The Abbé Grégoire and the French Revolution, the Making of Modern Universalism (London, 2005) p141

${ }^{177}$ Cambry, Voyage p.27

178 Ibid., p28

179 lbid., p158

180 Ibid., p143-4
} 
Cambry's remarks were fairly typical of the way in which popular culture was constructed as an object of study in the statistiques départementales. Louis Texier-Olivier, prefect of the Haute Vienne and author of the 1808 statistiques départementales made use of similar clichés about the simplicity of the inhabitants of the department,: 'Lents à la conception, les habitants du département de la Haute Vienne ont cependant de l'esprit naturel'. ${ }^{181}$ According to Texier-Olivier, the inhabitants of the Haute Vienne could be rescued from their slowness and simplicity only through exposure to French science and civilisation ; 'avec une éducation soignée, ils ne différent point de ceux des autres François, qui passent pour avoir le plus d'aptitude pour les sciences et les arts'. ${ }^{182}$ The production of social knowledge under Napoleon reveals a central ideological tenet of Napoleonic governance. Efficient and effective administration of society by the state, it was argued, could lead to the improvement of society. The description of archaic and backwards cultural practices gave purpose to French rule, both within France and in the départements réunis. As scholars such as Michael Broers and Michael Woolf have observed, this kind of superiority pervaded the mentality of administrators across the Empire during the period. It was what they believed made the enlightened rule of the French necessary. ${ }^{183}$ It also made the cultural integration of the populations of the Empire an object of Napoleonic rule, and this meant the spreading the French language.

\section{Language in the Napoleonic Statistics}

The study of the spoken language of the French, as opposed to the grammatical, standardized language of written production, gained prominence in France with the 1775 publication of an essay on the patois of Ban de la Roche by Jérémie-Jacques Oberlin. ${ }^{184}$ Oberlin's

\footnotetext{
${ }^{181}$ M.L. Texier-Olivier, Statistique générale de la France: Département de la Haute-Vienne (Paris, 1808) p.96 182 Texier-Olivier, Haute-Vienne p.96

${ }^{183}$ Broers, 'Cultural Imperialism', Past \& Present pp.159-63 ; Woolf, 'French Civilization', Past \& Present p.11920

$184 \mathrm{JJJ}$. Oberlin, Essai sur le patois lorrain des environs du Comté du Ban de la Roche, fief Royal d'Alsace (Strasbourg, 1775)
} 
essay, concerned with the langue d'oil variety spoken at the eastern most edge of Alsace, was the first study dedicated explicitly to one of France's regional languages. Oberlin began his work with the following disclaimer; 's'il étoit question de donner une description détaillée des différens [sic.] patois, qui distinguent les provinces du Royaume, il faudroit pour la faire, qu'il y eut une Académie formée par des sçavans de chaque province $\&$ des gens en même temps de la plus basse extraction' ${ }^{185}$ Such a proposition made it clear that the distinction between the French-speaking and non French-speaking populations of France was a social, as well as an ethnic one. Authentic samples of those languages particular to various 'provinces' of France could only be found amongst those of 'basse extraction'- 'le peuple', but it was to the educated that the study of such languages would be entrusted. This was a trope that surfaced repeatedly in studies of regional language and culture in France throughout the period. For example, in an article on the 'accent breton-armoricain' one member of the Académie celtique observed 'qu'en parlant de l'accent Breton, je suppose toujours cette langue dans la bouche des cultivateurs, des artisans et des gens du peuple, à qui elle est naturelle. ${ }^{186}$ This was because those who habitually spoke in French tended to employ 'la quantité et l'accent de cette langue lorsqu'elles veulent parler breton, circonstance qui leur fait perdre beaucoup de son originalité. ${ }^{187}$

Linguistic diversity, therefore, was understood as a feature of popular culture in the same way as the superstitions and customs described by figures like Cambry and Texier-Olivier. This made language a legitimate site for the enlightened intervention of the state, something that became clear during the Revolution, when the Abbé Grégoire circulated a series of 43 questions on the patois of France. ${ }^{188}$ Grégoire's questionnaire, which was printed in the newspaper Le patriote française and attracted responses from across France, predominantly from the Sociétés des amis de la

\footnotetext{
185 Oberlin, Essai p.1

${ }^{186}$ M. Dubois 'Remarques sur l'accent Breton-armoricain', Mémoires de l'Académie Celtique t.5 no.13 (1810) p.36

187 Dubois 'Remarques sur l'accent Breton-armoricain'

${ }^{188}$ Certeau et. al., Une politique de la langue pp.13-6
} 
constitution, was conceived as the first step in a campaign to homogenise the linguistic culture of France. ${ }^{189}$ The questionnaire itself made this goal explicit, requiring the respondent to consider the religious and political effect of the destruction of the patois and to reflect on how this might be brought about. ${ }^{190}$ Yet Grégoire also sought to collect a range of information on the use of France's other languages across contexts like the church and schoolroom, as well as the proverbs and vocabulary characterising popular speech and the printed material produced in these languages. ${ }^{191}$ Grégoire's survey, along with his Rapport sur la nécessité et les moyens d'anéantir les patois et d'universaliser l'usage de la langue française, which he presented to the convention in 1794 , have been understood as manifestations of a state linguistic policy aimed at the displacement of regional languages with French. ${ }^{192}$ Grégoire offered a damning verdict of the French people's ability to speak French:

On peut assurer sans exagération qu'au moins six millions de Français, surtout dans les campagnes, ignorent la langue nationale; qu'un nombre égal est à peu près incapable de soutenir une conversation suivie; qu'en dernier résultat, le nombre de ceux qui parlent n'excède pas trois millions, et probablement le nombre de ceux qui l'écrivent correctement encore moindre. ${ }^{193}$

This posed an obvious problem for the revolutionaries, for while it was desirable that all Frenchmen should be citizens capable of occupying places in the political administration,

si ces places sont occupés par des hommes incapable de s'énoncer, d'écrire dans la langue nationale, les droits des citoyens seront-ils bien garantis par des actes dont la rédaction présentera l'impropriété des termes, l'imprécision des idées, en un mot tous les symptômes de l'ignorance ? ${ }^{194}$

It is telling, however, that Grégoire distinguishes not simply between those who are able to speak French and those who are not, but also between those who are able to use French 'properly' and those whose grasp of the language is so tenuous as to invite 'error'- an 'imprecision' of ideas- that could spell political disaster.

\footnotetext{
${ }^{189}$ Certeau et. al., Une politique de la langue pp.26-30

190 lbid, p.15

${ }^{191}$ R. Chartier The Cultural Origins of the French Revolution (London, 1991) pp.139-40

192 Higonnet 'The Politics of Linguistic Terrorism' p. 42; J.Y. Lartichaux, 'Linguistic Politics during the French Revolution', Diogènes, vol.97 (1977) p.69; Certeau et.al., Une politique de la langue p.12

${ }^{193}$ H. Grégoire, 'Rapport sur la nécessité et les moyens d'anéantir les patois et d'universaliser l'usage de la langue française' in Certeau et. al. Une politique de la langue p.334

194 Grégoire, 'Rapport' p.335.
} 
While language was not an explicit object of the Napoleonic statistiques départementales, the frequency with which it appeared in the studies of the period demonstrates its enduring relevance as an object of official concern. Of 87 statistiques départementales published between the year VII and 1813, 40 describe the language of the department's inhabitants. The geographical distribution of these statistics, shown in Figure 1, unsurprisingly reflects the linguistic geography of the Empire. Concern over language was expressed predominantly, although not exclusively, in the Occitan speaking south of the country, in Brittany, and in the départements réunis of the Rhineland, Belgium and the Netherlands. The map also reveals the irregularity with which concerns about language were expressed in the South, with the statistiques départementales for a number of departments in Occitan-speaking territory making no mention of language. It should also be noted that the language of the population was an object of administrative enquiry in several departments of the North where dialects of the Langue d'oïl were spoken, such as the Haute Saône and the Deux Sèvres. ${ }^{195}$

Comparing the date of publication of statistiques départementales that included information on language, given in Figure 2, with the publication dates of those that do not, which are given in Figure 3, it appears that language featured more prominently as the practice of statistical description broadened to include greater detail on social and cultural practices. As Figure Two shows, very few of the early Descriptions abrégées contained information on language, even where the issue was later recognised as significant. Thus Farnaud's Description abrégée du département des Hautes Alpes, which appeared in the year VII, made no mention of language, while Bonnaire's Statistique du département des Hautes Alpes, published three years later did, albeit briefly. ${ }^{196}$ Some departmental statistics provided substantial detail on the local language, even including linguistic samples. Pierre Laboulinière, the Secrétaire de la préfecture of the Hautes Pyrénées included five

\footnotetext{
195 J.P. Vergnes, Mémoire sur la statistique du département de la Haute-Saône (Paris, an IX) pp.63-4 ; C.F.E. Dupin Mémoire statistique du département des Deux-Sèvres (Paris, an XII) p.214

${ }^{196}$ P.A. Farnaud, Description abrégée du département des Hautes-Alpes (Paris, an VII); F. Bonnaire Statistique du département des Hautes-Alpes (Paris, an X) p.98
} 
songs in Béarnais in his Annuaire statistique, while Texier-Olivier inserted a song and a translation of the parable of the prodigal in Limousin into his work on the Haute Vienne. ${ }^{197}$

Language in the statistiques départementales of the Napoleonic period appeared as an obstacle to the process of improvement upon which government legitimacy rested. In his work on the Belgian department of the Lys, the prefect Justin de Viry complained that rural dwellers in the area refused agricultural improvements like new livestock breeds because of ignorance fermented by a lack of knowledge of the French language. ${ }^{198}$ Integrating the culturally and linguistically diverse populations of the Empire meant spreading the French language. This position was expressed with particular clarity by Boucqueau, prefect of the Rhenish department of the Rhin et Moselle. As he wrote,

C'est ici le moment où les peuple soumis aux mêmes lois parleront la même langue ; c'est alors, seulement, que rien ne les distinguant pas, ils prendront tous les goûts et des habitudes semblables ; que les communications entre eux seront plus agréables, et qu'ils formeront un tous homogène qui compose vraiment une nation'. ${ }^{199}$

The Napoleonic project as understood by figures such as Viry, therefore, involved the homogenization of not only legal conventions and government structures, but cultural practices such as language, and the description of society was a crucial first step in this project of linguistic integration.

\section{The Coqueberts and the Languages of the Napoleonic Empire}

It was from this context that the enquiry into the languages of the French empire, conducted by the Bureau de la statistique between 1806 and 1812, emerged. The enquiry is commonly associated with the name Coquebert de Montbret. However, it was in reality the work of two individuals, Charles-Étienne Coquebert de Montbret, who ran the Bureau de la statistique from 1806 until 1810, when he was posted to Amsterdam to administer the imperial blockade in the trading

\footnotetext{
197 Laboulinière, Hautes-Pyrénées pp.297-304 ; Texier-Olivier, Haute-Vienne pp.106-7

198 J.M.F.J. de Viry, Mémoire statistique du département du Lys (Paris, an XII) pp.134-5

${ }^{199}$ Boucqueau, Rhin-et-Moselle p.124
} 
cities along the Roer, and his son and employee at the Bureau, Eugène. ${ }^{200}$ It is unclear where the initial impulse for the enquiry originated, for a letter from November 1807 Charles-Étienne Coquebert de Montbret credits the idea to Champagny, the then Minister of the Interior. ${ }^{201}$ Yet it was undoubtedly the Coqueberts who gave the enquiry its shape, for the draft versions of the Bureau's correspondence are almost entirely written in the hand of either father or son.

Furthermore, the Coqueberts retained an interest in the subject during the restoration, publishing an essay on the linguistic geography of France in 1831 which is attributed to Eugène in the catalogue of the Bibliothèque nationale, but may have been the work of Charles-Etienne in view of a similar manuscript in his hand. ${ }^{202}$

Disentangling the efforts of one Coquebert from another is an equally difficult proposition when it comes to the realisation of the enquiry itself. Upon the dissolution of the Bureau de la statistique in 1812, Eugène wrote a report for the Minister of the Interior outlining what had been completed so far and asking to be allowed to continue the work in his new posting. In an unsigned letter accompanying this report, it was claimed that 'c'est M. Eugene Coquebert qui a tenu cette correspondence, $c^{\prime}$ est lui qui a réuni et classé les renseignements' ${ }^{203}$ The largest share of the draft correspondence relating to the enquiry was written in the hand of the younger Coquebert, and certainly one may presume that the task fell to him after his father's departure from the Bureau in 1810, although much of the earliest correspondence is in Charles-Étienne's hand. ${ }^{204}$ The elder Coquebert's script is also evident in corrections made to Eugène's drafts. ${ }^{205}$ Father and son,

\footnotetext{
200 On the Coqueberts de Montbret see I. Laboulais-Lesage Lectures et pratiques de l'éspace: L'itinéraire de Charles-Étienne Coquebert de Montbret, savant et commis d'état (Paris, 1999)

201 Laboulais-Lesage Lectures et pratiques p. 392.

${ }^{202}$ E. Coquebert de Montbret 'Essai d'un travail sur la géographie de la langue française' in Mélanges sur les langues, dialectes et patois (Paris, 1831) ; Isabelle Labouais-Lesage suggests its reatribution based on a manuscript held in the Bibliothèque Municipale de Rouen, Ms. Mbt. 872 (Notes de M. Montbret sur les patois) ; see Laboulais-Lesage Lectures et pratiques p. 451.

${ }^{203}$ BnF Naf 20080 (Collection Coquebert de Montbret- Linguistique 1)

${ }^{204}$ BnF Naf 5910 (Patois de la France 1- Ain- Eure) Coquebet de Montbret au maire de Marseille 22 Jun. 1807 f.149

${ }^{205}$ BnF Naf 5910 Coquebert de Montbret au préfet de l'Ain, 30 Sep. 1807 f.18
} 
therefore, worked together on the enquiry, and while Eugène may have been more closely involved with its workings, particularly in its last two years, Charles-Étienne's seniority was also evident.

Charles-Étienne Coquebert de Montbret was an assiduous amateur geographer. The elder Coquebert owned a collection of 856 maps, and took voyages around France and Ireland, always accompanied by selection of these maps on which to mark down the geological, agricultural and linguistic features he encountered. ${ }^{206}$ Upon returning home, he would add details from travelogues and his own correspondence. He was a founding member of the Société de géographie in 1821, collaborated with Omalius d'Halloy on the creation of geological maps of France, and was elected a member of the Academy of Science in $1816 .{ }^{207}$ Perhaps unsurprisingly, therefore, the enquiry into the languages of the Empire overseen by the Coqueberts was essentially an attempt to localise linguistic diversity in geographical space. To this end, the Coqueberts carried out an extensive correspondence with various figures in the local administration from across the Empire, and the bureau amassed a prodigious quantity of documentation penned by a slew of prefects, sub-prefects, clergy, teachers, lawyers and other provincial notables ${ }^{208}$. Linguistic maps, perhaps the earliest of their kind, reside in the archive alongside songs, poems and other samples of dialects, some in print, but mostly in manuscript. Lengthy antiquarian disquisitions on the history of the respondent's commune are accompanied by vocabulaires and grammatical treatises aimed at describing the local language.

While the urge to locate the linguistic diversity of the population in geographic space coloured the entire enquiry, it should be noted that an important shift in the object of study took place at the end of 1806, a shift that has lead commentators such as René Merle to claim that we are

\footnotetext{
${ }^{206}$ I. Laboulais-Lesage 'Reading a Vision of Space: the Geographical Map Collection of Charles-Etienne Coquebert de Monbret' in Imago Mundi vol. 56 no.1 p. 54. Charles-Étienne's notebook from his journey around Ireland has been published; C.-E. Coquebert de Montbret, I. Laboulais-Lesage (ed.) Voyage de Paris à Dublin à travers la Normandie et l'Angleterre en 1789 (Saint-Etienne, 1995). His map collection, held at the Bibliothèque municipale de Rouen has also been digitised ; http://www2i.misha.fr/flora/isp/indexCDM BCDM.jsp (accessed 03/07/2014)

${ }^{207}$ Laboulais-Lesage, 'Reading a Vision of Space' p.48 ; Lectures et pratiques p.465

${ }^{208}$ R. Merle, Visions de "L'idiome natal » à travers l'enquête impériale sur les patois (1807-1812) : (Langue d'oc, Catalan, Francoprovençal) France, Italie, Suisse (Canet, 2010) pp.19-35
} 
dealing not only with two Coqueberts, but with two enquiries. ${ }^{209}$ Eugène himself understood the enquiry as taking place in two distinct phases. This much is clear from Eugène's draft report of 1812 as well as the draft versions of the letters sent out by the Bureau to its respondents in the provinces. Thus in 1806 the elder Coquebert expressed his intentions to the prefect of the arrondissement of Malmedy in the Belgian department of the Ourthe, claiming that the departmental statistics published up to that point had not traced 'avec assez de soin les limites de la langue Françoise circonstance bien importante cependant sous un grand nombre des rapports' ${ }^{210}$ In his 1812 report, Eugène echoed his father, claiming that 'on a pensé que le premier pas à faire devait consister à déterminer avec précision les limites de l'étendue de pays dans laquelle se parle chacun des idiomes principaux que l'on peut considérer comme des Langues Mères' ${ }^{211}$ These 'Langues Mères' identified by Eugène were French, German, Italian, Flemish, Breton and Basque, and once the geographic limits were defined the population of speakers of each language was calculated from census data. The second stage was also concerned with linguistic geography, but moved beyond the notion of languages to that of dialects. According to Eugène, the aim was 'à tâcher pareillement de reconnaitre les principaux points qui circonvoisent [sic.] à peu près le territoire qu'occupe chaque dialecte secondaire de ces diverses langages principaux. ${ }^{212}$ This ambition saw the Coqueberts cleave the map of France into two great chunks, the Langue d'oc and Langue d'oïl-speaking regions, a distinction that would recur throughout the nineteenth century and beyond, and then break these areas down further into smaller dialect zones. ${ }^{213}$

It would appear that the enquiry was initially conceived with administrative ends in mind, and the project had potential applications in the administration of the Empire. The Revolution witnessed the complete spatial reorganisation of the administrative structures of the French

\footnotetext{
${ }^{209}$ Merle, Visions p.9

${ }^{210}$ An F 171209 (Enquête sur les Patois) Coquebert de Montbret au sous-préfet de l'arrondissement de Malmedy, Département de l'Ourthe, 29 Jul. 1806

${ }^{211}$ BnF Naf 20080 (Collection Coquebert de Montbret- Linguistique 1) f.2

212 BnF Naf 20080 f.3

${ }^{213}$ P. Martel, « De Coquebert de Montbret à Joanne ; À la découverte du « Midi » ? " in D. Fabre and J.-M. Privat (eds.), Savoirs Romantiques : Une naissance de l'ethnographie (Nancy, 2010) pp.165-6
} 
territory, from the irregular pays d'élection and pays d'état of the Old Regime to more uniform departments. Questions over the administrative organisation of the nation's territory reappeared as France's borders expanded, bringing non-Francophone areas with no history of carrying out administration or justice in French under the purview of the French ministries. As a result, language increasingly became an issue in the demarcation and organization of administrative and juridical structures. Under the Consulate Jean-Batiste-Moïse Jollivet, the Commissaire générale $d u$ gouvernement for the territories annexed on the left bank of the Rhine, proposed reducing from four to three the number of départements réunis into which this territory was divided. As part of this reorganisation he sought to detach the canton of Reifferscheid from the Sarre and attach it to the canton of Scheiden in the Ourthe. Although his principle justification was to maintain parity in the department's populations, the German speaking nature of these two cantons made such a reorganisation more desirable. As Jollivet commented; 'il est d'ailleurs à observer que les Communes qui composent actuellement le Canton de Schleiden [...] parlent la même langue et ont les mêmes usages et habitudes que ceux du canton de Reifferscheid auxquels on a proposé avec d'autant plus de raison de les réunir.'214

During the summer of 1806 discussions concerning the establishment of French rule over the territories that had been annexed during the Revolutionary and Napoleonic wars made the question of language a live one within the Ministry of the Interior. This much is clear from a letter sent by the Minster of Justice to the Minister of the Interior in June 1806, concerning the use of the French language in the occupied departments of Northern Italy:

J'ai déjà soumis, il y a quelque temps à sa majesté la question qui fait objet de votre lettre du 2 de ce mois, touchant la nécessité de prolonger le délai pour l'emploi de la langue française dans les départements composant la cy-devant ligurie. Je vais appeler de nouveau I'attention du conseil d'état sur cet objet. ${ }^{215}$

\footnotetext{
${ }^{214}$ An BB5 255 (Organisation judiciare- , rive gauche du Rhin) Etat des Communes des quatre nouveaux départements qu'on propose de réunir aux départements de l'Intérieur ${ }^{215}$ BnF Naf 5911 (Patois de la France II- Gard-Nord) Ministre de la justice au ministre de l'intérieur, 14 Jun. 1806 f.23
} 
It is intriguing that this letter should have found its way into the documentation produced by the enquiry. It does, however, make clear that the Coqueberts' initial efforts, in seeking to define the territory of the French language, was not unrelated to the concerns of a government attempting to organise and administer a multi-lingual Empire.

It is equally clear, however, that while the enquiry began as an administrative project, its final form, concerned above all with the dialects of the French Empire, owed more to the antiquarian interests of the Coqueberts themselves. The report drafted by Eugène in 1812 was essentially an unsuccessful plea to continue the enquiry following the dissolution of the Bureau de la statistique, which was closed largely due to its inability to respond promptly to government requests for information on material conditions. ${ }^{216}$ When the translations gathered by the Coqueberts to describe the languages of the Empire were published after the fall of Napoleon they appeared in the Mémoires of the Société des antiquaires. ${ }^{217}$ The enquiry should thus be considered a composite work, carried out over a lengthy period of time and shaped both by the administrative and scholarly concerns of the Coqueberts.

\section{The Limits of the French Language and the Mother Tongues of the Empire}

The Coqueberts' initial forays into the study of language took place in the summer of 1806 , and concerned as they were with the frontiers between French speaking regions and those areas where German, Flemish, Basque and Catalan were spoken, bear witness to the burgeoning multilingualism of the French state ushered in by the military advances of the Revolution and Empire. In pursuit of these linguistic borders the Coqueberts had two types of sources produced; a collection of linguistic maps, now held at the Bibliothèque nationale, ${ }^{218}$ and a number of nominative lists, composed for

\footnotetext{
${ }^{216}$ Laboulais-Lesage, Lectures et pratiques p.441

217 'Matérieux pour servir à l'Histoire des Dialectes de la Langue française, ou Collection de versions de la parabole de l'enfant prodigue en divers idiômes ou patois de France, in Mémoires de la société royale des antiquaires de France vol.6 (1824) pp.432-545

${ }^{218}$ BnF Naf 5913 (Patois de la France IV- Limites de la Langue Française) contains linguistic maps of the following departments ; Côtes du Nord, Meurthe, Hte. Rhin, Bas Rhin, Hte. Pyrénées, Basses Pyrénées, Nord, Lys, Jemmapes, Dyle, Ourthe, Meuse Inférieur, Po, Doire, Alpes Maritimes. Several of these maps have been
} 
different arrondissements by the relevant sub-prefects. These lists, which are now spread between the Bibliothèque nationale and the Bibliothèque municipale de Rouen, where the family papers were deposited by Eugène Coquebert de Montbret, gave the names of the arrondissement's communes, the language spoken therein, and sometimes the population of these communes. ${ }^{219}$ The dates of the correspondence relating to this effort at linguistic geography show that the enquiry began sometime in the summer of 1806, with the responses arriving between late July and October of that year.

This data on the geographic spread of languages was used by the Coqueberts to calculate the populations of speakers of the various languages spoken in the Empire. These figures, which are given in Table 1, were presented in a report dated 1808, and then in the Coqueberts' 1831 publication on the subject. ${ }^{220}$ In the 1808 report, Eugène Coquebert de Montbret outlined the method followed to arrive at these figures; first 'authentic' information was compiled on the limits of each language in those departments where languages other than French were in use. Then, the population of 'toutes les communes qui dans les départements de langue mixte parlant le même idiome' was counted, giving the number of speakers of languages other than French in the territories

Table 1: Population of the First French Empire by Language

\begin{tabular}{|l|c|}
\hline Langue Française & $28126000^{*}$ \\
\hline Langue Italienne & 4079000 \\
\hline Langue Allemande & 2705000 \\
\hline Langue Flamande & 2277000 \\
\hline Langue Bretonne & 967000 \\
\hline Langue Basque & 108000 \\
\hline Total & 38262000 \\
\hline
\end{tabular}

* In the 1831 publication of these figures the population of speakers of French 'dans ses differens dialectes et patois' is given as 27926000 . The rest of the figures remain the same giving a total population of 38062000 .

reprinted in M.-V. Ozouf-Marignier, D. Nordman, R. Gimeno and A. Laclau, Atlas de la Révolution française vol.4- Le territoire pt 1 Réalités et représentations (Paris, 1989) pp69-71; For a discussion of these maps and their place in the tradition and development of cartographic representaitons of linguistic diversity see Nordman Frontières de France pp. 465-472 ; C.T. Dunlop 'Mapping a New Kind of European Boundary : The Language Border between France and Germany', Imago Mundi vol.65 no.2 (2013) pp.255-6

${ }^{219}$ BnF NAaf 5913 Malmedy (Ourthe) f. 30, 42 ; BmR Ms Mbt. 191 (Notes sur les limites de la langue française) ; Ms Mbt 721 (Recueil de Linguistique).

${ }^{220}$ An F12 1566 Population de la France et langues parlées dans l'Empire ; Coquebert de Montbret 'Essai d'un travail sur la géographie de la langue française' p. 15. 
of the Empire. ${ }^{221}$ This produced a more accurate result than the Abbé Grégoire's frequently cited yet vague assertion that 6 million Frenchmen spoke no French, and only 3 million spoke it properly. Indeed, while frequently quoted uncritically as evidence of France's linguistic diversity, Grégoire's numbers should probably be treated as a rhetorical flourish rather than a statistical fact, for nothing in the papers he amassed on the subject hint at how he arrived at such numbers. ${ }^{222}$

The Coqueberts' efforts represent the first serious attempt to quantify France's linguistic diversity. However, despite Eugène Coquebert's claims that the work he and his father had carried out should be considered as more than 'un simple aperçu hypothétique,'223 the outline of the method they used made clear that his own figures should be treated as little more than indicative. The Coqueberts were forced to assume that languages occupy homogenous territories, and that either side of a linguistic 'line of demarcation' the population was effectively monolingual. Yet as the correspondence relating to his effort makes clear, the situation was not always this straightforward. For example, the sub-prefect of the arrondissement of Saint-Dié in the Vosges claimed that 'de toutes les communes de la cy-devant [sic.] province d'Alsace comprises dans le Dépt. des Vosges, celle de Malzville, Canton de Schizmecll est la seule où la langue Allemande soit plus généralement usitée que la langue française' ${ }^{224}$ As for the other Alsatian communes in the sub-prefect's arrondissement, 'on y comprenne l'allemand mais tous les habitants ne parle que français, et ce n'est qu'à Malzville que la majeure partie des habitans [sic.] ne parle que la langue allemande.'225 The Coqueberts' method offered no way of representing such degrees of bilingualism, with settlements such as Malzville simply placed on one side or the other of the language boundary. The Coqueberts encountered similar problems in Brittany. In October 1806, the prefect of Morbihan

\footnotetext{
${ }^{221}$ An F12 1566 Population de la France et langues parlées dans l'Empire

222 Much of Grégoire's correspondence on the subject has been reprinted in A. Gazier (ed.) Lettres à Grégoire sur les patois de France (Paris, 1880) with additional material reproduced in the appendices of de Certeau et. al Une politique de la langue.

${ }^{223}$ An F12 1566

${ }^{224}$ BnF Naf 5913 Le sous-préfet de l'arrondissement communal de Saint-Dié, département des Vosges au ministre de l'intérieur, 23 Aug. 1806 f.6

${ }^{225}$ BnF Naf 5913 Le sous-préfet de l'arrondissement communal de Saint-Dié, département des Vosges au ministre de l'intérieur, 23 Aug. 1806 f.6
} 
wrote to Coquebert, who had expressed concerns over the accuracy of the linguistic border indicated by the prefect, explaining the reasoning behind his placement of the line. According to the prefect, the course of the river Vilaine marked, for the most part, the line separating Frenchspeaking communes from Breton-speaking ones. However, 'dans les trois communes de Panerin, Camoel \& Ferrel la langue française soit réellement la dominante, je ne l'ai comprises dans ma ligne de démarcation, parce qu'on y parle aussi le Breton, quoique moins universellement dans le pays en deça de cette rivière'. ${ }^{226}$ The prefect had therefore included these communes within the Bretonspeaking area, 'afin de n'omettre aucune de celui où le Breton est connue'. .27 The Coqueberts recognised this difficulty ; 'Je n'ai pas besoin de vous dire' the elder Coquebert wrote to the subprefect of Malmedy by way of instruction, 'que je regarde comme appartenant à la langue allemande toute commune où cette langue est parlée habituellement quand même on useroit concurremment de la langue Françoise'. ${ }^{228}$ As this attempt to add greater precision to their efforts at mapping demonstrates, bilingualism continued to elude their representations of linguistic space.

The responses to the Coqueberts' enquiry indicate that bilingualism of various degrees was a common phenomenon along the zones of linguistic contact. The prefect of the Loire-Inférieure informed the Coqueberts that French was the language of his department, while 'quant à la langue celtique ou bas breton, il n'est en usage que comme moyen de communication avec les habitans [sic.] des autres départemens [sic.] de la Bretagne' ${ }^{229}$ Similarly, in his letter concerning the Basque language, the prefect of the Basses-Pyrénées commented that 'dans beaucoup de communes de la langue française une grande partie d'habitans [sic.] savent la basque. C'est un effet naturel des relations qu'ont entr'eux ces peuples voisins et qu'on aperçoit dans toutes les frontières' ${ }^{230} \mathrm{~A}$ similar observation was made by the prefect of the Belgian department of Jemappes, who claimed

\footnotetext{
${ }^{226}$ BnF Naf 5911 Le préfet du Morbihan au ministre de l'intérieur, 31 Oct. 1806 f.349

${ }^{227}$ BnF Naf 5911 Le préfet du Morbihan au ministre de l'intérieur, 31 Oct. 1806 f.349

${ }^{228}$ An F17 1209 Ministre de l'intérieur à M. de Perigny, sous-préfet de l'arrondissement de Malmedy 28 Jul. 1806

${ }^{229}$ BnF Naf 5911 Le préfet de la Loire-Inférieure au ministre de l'intérieur, 6 Jul. 1812 f.229, emphasis in original

${ }^{230}$ BnF Naf 5913 Le Préfet des Basses-Pyrénées au Ministre de l’Intérieur, 22 Jul. 1806 f.14
} 
that Flemish was in use only in the villages of Bievene and Absennes, but that interactions with nearby Flemish speakers encourgaged individuals to learn the language ; 'à cause de nos relations d'intérêt avec les flamands, dont nous somme limitrophes, il y a toujours eu, dans tous les endroits de notre canton, et notamment dans notre ville, des personnes qui se sont fait un devoir d'apprendre leur idiôme [sic.]'.231 As these comments imply, this kind of bilingualism seems to have been particularly the case amongst those sections of the population who were mobile, such as those involved in commerce. Thus the prefect of the Loire-Inférieur, quoting the statistique départementale published in 1794, explained that in the environs of Guérande, a commune home to large salt marshes and situated in the north of the Loire-Inférieure on the border with the department of Morbihan about 60 kilometres from the market town of Vannes, there existed several villages 'où l'on parle également le française et le celtique vannetais.' It was claimed that 'l'usage de ces deux langues leur est nécessaire pour la troque, pour le commerce d'échange qu'ils font avec les départemens au-delà de la vilaine où ils portent du sel et dont ils tirent les grains qu'ils consomment'. ${ }^{232}$

\section{From 'Langues Mères' to 'Dialectes Vulgaire'}

Having described the limits of the French language in relation to its neighbours in just a few months, the Coqueberts moved rapidly onto an attempt to outline the distribution of dialects throughout the territory of the French Empire. This attempt led the Coqueberts to move beyond the classification of languages such as French, German, Italian, Dutch, Flemish, Basque and Breton, breaking them down into smaller dialect zones. To this end, the Coqueberts collected numerous samples of the language in use across the Empire. To facilitate comparison they chose a uniform text, the parable of the prodigal son, to be translated into these 'idiomes d'un usage vulgaire'. This in itself was something of a departure, for while translations of biblical passages had long fulfilled the purpose of describing and comparing languages, it was invariably the Lord's Prayer that was used. In

\footnotetext{
${ }^{231}$ BnF Naf 5911 Le préfet de Jemmapes au ministre de l'intérieur, 24 Sept. 1807 f.194

${ }^{232} \mathrm{BnF}$ Naf 5911 Le préfet de la Loire-Inférieure au ministre de l'intérieur, 6 Jul. 1812 f.229
} 
the mid-sixteenth century Conrad Gessner collected 130 versions of the pater noster in various languages, and the same piece was used to describe the languages of the indigenous peoples of North America in works like Champlain's Voyages dans la nouvelle France. ${ }^{233}$ The Coqueberts were well aware of this tradition, but felt the Lord's Prayer too short and too abstract to form the basis of a comparative project. The parable of the prodigal son was longer and had 'le mérite de ne renfermer que des idées simples et familières à tout le monde'. ${ }^{234}$ The Coqueberts requested the first of these translations in September 1806 from the department of the Haut Rhin. It was only at this moment that the parable was chosen, for the letter contains a crossed out passage reading 'quant au choix des morceaux à [...] faire traduire dans ces divers idiomes je m'en rapporte entièrement à vous', replaced by the demand for a translation of the parable. ${ }^{235}$ According to Eugène's 1812 report, the Coqueberts collected more than 350 versions of the parable from 74 departments, each one representing a different dialect, idiom or patois. ${ }^{236}$ They also received a diverse collection of songs, fragments of plays, grammatical essays and dictionaries of local dialect. Linguists have subsequently used these documents to illustrate descriptions of language change in these dialects. ${ }^{237}$

In contrast to the initial phase of the enquiry, that had primarily been carried out by the prefects, sub-prefects and mayors of the areas with which the Coqueberts were concerned, the

\footnotetext{
${ }^{233}$ C. Gessner, Mithridite, de diversis Linguaes (1553) ; S. Champlain, Les voyages de la nouvelle France (1632)

234 BnF Naf 20080 f.5

${ }^{235}$ BnF Naf 5913 Coquebert de Montbret au sous-préfet de Délémont, département du Haut-Rhin, 15 Sep. 1806 (Brouillon) f.5

${ }^{236}$ BnF Naf 20080 f.5 The translations are predominantly held across three institutions ; AN F 171209 (Enquête sur les Patois); BnF NaF 5910-5912; BmR Ms Mbt 189, Ms Mbt 433, Ms Mbt 489 (Notes de M. de Montbret sur le patois). However, some translations have only survived through publication ; L. Duval, 'L'enquête philologique de 1812 dans les arrondissements d'Alençon \& de Mortagne, Vocabulaires, Grammaire et Phonétique', Actes de la Société Philologique vol.28 (1889) ; J.J. Champollion-Figeac, Nouvelles Recherches sur les Patois ou Idiomes Vulgaires de la France et en particulier sur ceux du département de l'Isère (Paris, 1809) ; D. Bernard, 'Une enquête ministérielle sur les dialectes Bretons sous le Premier Empire', Annales de Bretagne vol. 60 no.1 (1953) pp.78-83; P. Le Roux 'Un texte dialectal de Haute-Cornouaille en 1811' Annales de Bretagne vol.60 no.1 (1953) pp.84-91

${ }^{237}$ H.E. Keller, 'L'enquête de Coquebert de Montbret dans la Lozère » in Mélanges de philologie romane offerts à Charles Comproux vol. 2 (Montpellier, 1978); Keller, 'L'enquête de Coquebert de Montbret dans le Jura Suisse' J. Cerquiglini-Toulet et O. Collet (eds.), Mélanges de philologie et de littérature médiévales offerts à Michel Burger (Droz, 1994); Keller, 'Le Parler du Bugey au début du XIXe siècle', Espace Romans, études de dialectologie et de géolinguistique offertes à Gaston Tuaillon (Grenoble, 1989) vol. 2 pp. 161-87
} 
second phase of the enquiry mobilised many other types of local notables, figures such as justices of the peace, mayors and local ecclesiastics, in providing translations of the local languages. The need to find individuals who were both literate and familiar with the local language meant that the local curé was frequently called upon, as the instructions to the justice of the peace of Pont de Vaux suggest ; 'je souhaiterais particulièrement que vous avez l'aide de quelque ecclésiastique au fait de leur langage populaire me procurer des échantillons de l'idiome usité parmi eux entr'autre une traduction dans ce patois de la parabole de l'enfant prodigue' ${ }^{238}$ However, the instructions were seldom so direct, generally going no further than requesting a translation of the parable of the prodigal son, and leaving the choice of translator up to the local official. The occupations of the 94 translators of the parable that can be identified, given in Table 2 and plotted as a pie chart in Figure 4, reveal the choices of the local prefect or sub-prefect responding to the Coqueberts' requests. Of the 94 translators, the majority- 51- were public administrators. Of this number 35 were mayors, the largest single occupational group. They were joined by 6 sub-prefects and 7 conseillers and secretaires de la préfecture, 2 mayoral adjuncts, a single prefect, tax collector and a naval forestry

Table 2: Translators of the Parable by Occupation

\begin{tabular}{|l|c|}
\hline Legal Professionals & 10 \\
\hline Teachers & 5 \\
\hline Clergy & 22 \\
\hline Mayors and Adjuncts & 35 \\
\hline $\begin{array}{l}\text { Councillors/Secretaries of the } \\
\text { prefecture }\end{array}$ & 7 \\
\hline Sub-prefects & 6 \\
\hline Prefects & 1 \\
\hline State Officials (other) & 2 \\
\hline Other & 6 \\
\hline Total & 94 \\
\hline
\end{tabular}

${ }^{238}$ BnF Naf 5910 Coquebert de Montbret au juge de paix du canton de Pont de Vaux, département de l'Ain 10 Aug. 1808 f.16 
inspector. The majority of the 22 clergy were curés, or desservants, along with one Protestant pastor. Those with a legal position comprised a notary, a lawyer and seven justices of the peace. Finally, a number of teachers from various establishments of secondary education also undertook translations. The profile of the Coqueberts' translators reveals a class of bilingual local notables, excluding the prefect, who was generally appointed from outside of the department, but comprising locals who filled positions in state administrative or legal bureaucracies, educational institutions, as well as the Church. ${ }^{239}$

\section{The Coqueberts and the Ambiguities of Nation Building under Napoleon}

For the historian, the value of the material gathered by the Coqueberts lies precisely in the diverse range of local figures that produced such a vast collection of documents about their own language. Whereas the statistiques départementales were generally edited by the prefect and parsed by the Ministry of the Interior, the correspondence generated by the Coqueberts' enquiry into language offers direct insight into the negotiation between Parisian centre and local society over the definition and value of local language. The next three chapters all concern in various ways this process of negotiation, either over the definition of local language or its status. These chapters will reveal the variety of positions taken by local officials and notables in the context of the centralizing pressure manifested in Napoleonic practices of social description. These ambiguities, it should be noted, were also present in the Coqueberts' own attitudes towards linguistic centralization.

The Coqueberts maintained that spreading French amongst the population was a desirable goal, but expressed doubt that such a change could be affected quickly, or at the whim of governments. Reflecting on the failure of Joseph II to foist German upon the Magyar population of his Empire, and on the linguistic conflicts erupting over the use of Dutch and French in Belgium, the

${ }^{239}$ Bourguet Déchiffrer pp.135-7 
Coqueberts expressed doubt that measures undertaken by the government would succeed in effecting linguistic change: ${ }^{240}$

Il ne faut pas croire que l'anéantissement des patois soit aussi prochain qu'on pourrait imaginer. On ne peut l'espérer que de la marche du temps, des progrès de l'instruction primaire, et de l'empire lent, mais assuré, de l'imitation. C'est en vain qu'on espérait hâter cette révolution par des mesures administratives. ${ }^{241}$

This statement was made fifteen years after the fall of Napoleon, and the passage of time could well have altered the Coqueberts' opinions. Yet the pessimism surrounding state power, the appearance of doubt not so much over the worth, but the possibility of transforming society, seems to mark a failure in the ideology of Napoleonic governance that matched the political failure of the regime itself.

However, as will become clear over the course of this thesis, such opinions were produced during the period through the complex two-way interaction between Paris and the provinces. Demands for linguistic centralization were met with precisely this kind of pessimism. In asserting the impossibility of imposing French in quick order, local officials were able to justify the continued use of other languages in official functions. The next chapter will examine one facet of this interaction between centre and periphery through the material produced by the Coqueberts- the divergent understandings of the very nature of linguistic diversity held on either side of this divide.

\footnotetext{
${ }^{240}$ Coquebert de Montbret 'Essai' p. 23 ; As part of his centralizing reforms, Joseph II had attempted to replace Latin, then the administrative language of Hungary, with German in 1784. The reforms were especially disliked by Magyar noblemen, and faced with resistance within Hungary and the prospect of war with Prussia the reforms were repealed by Leopold II at the Diet of Preßburg in 1790-1. In 1823, Willem I had similarly enshrined Dutch in place of French as the official language of the Kingdom of the Netherlands, and the measure was reversed in favour of French following the Belgian revolution of 1830. T. Kamusella The Politics of Language and Nationalisms in Central Europe during the Nineteenth and Twentieth centuries (Basingstoke, 2009) pp.433-9 ; E. Vanhecke, J. de Groof 'New Data on Language Policy and Language Choice in $19^{\text {th }}$ Century Flemish City Administrations', S. Elspaß, N. Langer, J. Scharloth, W. Vanderbussche (eds) Germanic Language Histories from Below, 1700-2000 (Berlin, 2007) pp.452-3

${ }^{241}$ Coquebert de Montbret 'Essai' pp.22-3
} 


\section{Visions of Linguistic Space: The Coqueberts de Montbret and the Languages of the French Empire}

What languages were spoken across the Napoleonic Empire? How did contemporaries understand the geography of linguistic difference? For the historian, this geography can apparently be easily grasped. Two centuries of research by linguists and dialectologists have made its contours familiar. The 's' curve separating Breton from French, the hump across the country's centre beyond which French becomes Occitan, the triangle of Francoprovençal and the division of Alsace, Lorraine and the Low Countries into Romance and Germanic varieties in the east- these shapes are easily evoked by historians and linguists in a single map which, placed at the head of a volume, can appear to convey the elemental foundations of European history. ${ }^{242}$ Such maps present linguistic difference as a feature of the territory of Western Europe that itself explains aspects of the historical development of the region. In so doing, they obscure the complexities of the social construction of minority identities, the changing shape of social knowledge and definitions of linguistic community. At the start of the nineteenth century the linguistic map of the Napoleonic Empire was not characterized by the neat territorial groupings of linguistic minorities that appear so self-evident today. Contemporaries were themselves unsure about the linguistic geography of France. This uncertainty has the potential to undermine the assumptions of historians about the role of linguistic geography in shaping historical experience, and was underscored by the Coqueberts' enquiry, an effort that represented the first serious attempt to give the linguistic geography of France its distinctive shape.

The Coqueberts produced a linguistic geography of Western Europe similar to the maps drawn by dialectologists, and as this chapter will argue they did so through adherence to a protolinguistic method based on the comparison of samples. However, in doing so they also unearthed a variety of different basis on which individuals identified with linguistic communities. Two other analytical tropes enjoyed particular prominence in the construction of linguistic identities among the

${ }^{242}$ Bell The Cult of the Nation p.16 ; E. Le Roy Ladurie Histoire de France des régions: La périphérie française, des origines à nos jours (Paris, 2001) p.21 
Coqueberts' correspondents- social class and place. The first of these, which understood linguistic difference as a feature of popular culture, is discussed at length in the next chapter. This chapter is concerned above all with the sense of place and local belonging that pervaded understandings of linguistic difference during the period. As this chapter will argue, these visions of linguistic space cut across the ethnic definitions of difference embraced by the Coqueberts, something of significance for understanding the social construction of linguistic minorities and the intersection between language and the structures of the Napoleonic state.

\section{Classifying Languages and Dialects}

For the Coqueberts, the interest of this material was its potential to inform a more complete linguistic geography of the French Empire. The Coqueberts understood linguistic diversity as a foundational characteristic of the population, a feature of the arcane folk culture of the peasant unaffected by education, economic change or technical innovation. As Eugène wrote of the linguistic separation between the Langue d'oil speaking north and Occitan speaking south of the country:

Cette distinction est effacée depuis longtemps sous le rapport politique et sous celui de la législation (car les provinces du Midi suivaient le droit Romain à l'exclusion de celles du nord où les diverses coutumes locales étaient seules en vigueur, mais elle subsiste encore relativement au langage, au mode de culture et à la manière dont les habitations sont construits. ${ }^{243}$

The Coqueberts considered linguistic difference a product of the long history of the peopling of Western Europe, constituting a series of distinctions over which the French state had been constructed. Such distinctions were more durable than political and administrative divisions, a point they reiterated in their 1831 essay on linguistic geography: 'On reconnut qu'après les divisions physiques, qui sont les seules naturelles et les plus importantes de toutes, il n'y en a pas qui doivent être préférées à celles qui résultent des ressemblances et des dissemblances entre les idiomes'. ${ }^{244}$

\footnotetext{
243 BNF NAF 20080 f.9

${ }^{244}$ E. Coquebert de Montbret 'Essai d'un travail sur la géographie de la langue française', S. Bottin (ed.) Mélanges sur les langues, dialectes et patois (Paris, 1831) p.7
} 
From this perspective, the geographies of language sought by the Coqueberts were of far greater significance than political or administrative boundaries:

Moins stables, sans doute, que les divisions physiques, elles le sont beaucoup plus que les divisions politiques et administratives. Des siècles suffisent à peine pour changer la langue d'un pays il ne faut au contraire qu'une guerre, un traité de paix, d'échange ou de vente, pour donner à une province de nouveaux maîtres. Mais en cessent d'être concitoyens, ontils cessé d'être compatriotes ces hommes que le langage unit par des noeuds permanens ?245

For the Coqueberts, therefore, language was a foundational characteristic of the individual, and linguistic minorities, implanted on their territories and bound together by the ties of a shared language and history, a fundamental feature of the geography of Europe.

The Coqueberts' view of language as a definitional feature of population raises the issue of whether they should be understood as proponents of an 'ethnic' view of linguistic identity. Language was central to the thought of nineteenth century ethno-nationalists. Giuseppe Mazzini, for example, would have recognised the basic features of the European national struggle in the Coqueberts' formulation. As he wrote in an 1847 essay directed towards a liberal British audience, against the backdrop of the rising political and social tensions that would eventually result in the 1848 revolutions:

Several races are struggling: millions of men placed by God's hand within fixed territorial boundaries, having a language of their own, as well as specific manners, tendencies, traditions and national songs. They are leashed and governed by other men whose manners, tendencies, and language are altogether foreign to them. ${ }^{246}$

Set aside Mazzini's religious language, which had no counterpart in the secular formulations of geographic and antiquarian discovery employed by the Coqueberts, and some parallels in the description of linguistic difference as one part of a foundational distinction between the character and manners of individuals composing the different nations of Europe do appear. Yet while, as we

\footnotetext{
${ }^{245}$ Coquebert de Montbret 'Essai' p.7

${ }^{246} \mathrm{G}$. Mazzini 'The European Question : Foreign Intervention and National Self-Determination', S. Recchia, N. Urbinati A Cosmopolitanism of Nations: Giuseppe Mazzini's Writings on Democracy, Nation Building and International Relations (Princeton, 2009) p.195
} 
saw at the end of the previous chapter, the Coqueberts were pessimistic about the ability of government to change linguistic practice, they did not see language as totally immutable. Moreover, there is no sense that the Coqueberts viewed language as a legitimate basis for national selfdetermination.

At the same time, the Coqueberts did not appear to subscribe to the kind of civic definition of community expressed by some French commentators faced with the extreme ethno-linguistic diversity that characterised the population of France. This was a view expressed by Merlin de Douai during the Revolution, with his frequently quoted claim that Alsace should be considered part of France not because of the treaty of Münster, but because the Alsatian people had chosen to become French, language and all. ${ }^{247}$ The Coqueberts, in contrast, sought to distinguish between linguistic communities, and the typology of linguistic groupings they produced was based on their understandings of the linguistic affinities between named varieties.

The Coqueberts produced two versions of this typology-Eugène's report to the Minister of the Interior in 1812, and the 1831 essay on the limits of the French language largely conforming to a draft document in Charles-Étienne's hand. ${ }^{248}$ According to Eugène's report, all of the dialects of the Empire were derived from four main language groupings; 'ils peuvent être rapportés sous 4 classes principles I. les idiomes dérivés du latin. II. ceux qui sont d'origine germanique III. le Bas Breton IV. le Basque'. ${ }^{249}$ These groupings were then broken down further into subsets of languages and their dialects. The languages deriving from Latin were grouped by Eugène under the headings of 'le français proprement dit,' the 'idiomes du midi', Italian and Gascon. With this last language a divergence emerged between the writings of Eugène and Charles-Ètienne. While the former designated Gascon as a language in its own right, the latter placed it alongside the other dialects of

\footnotetext{
${ }^{247}$ P. Serna, 'Tout révolution est guerre d'indépendance' in J.-L. Chappey, B. Gainot, G. Mazeau, F. Régent, and P. Serna (eds) Pour quoi faire la Révolution (Marseille, 2012) p.20 Brunot Histoire de la langue française vol.9 p.4 ${ }^{248}$ Coquebert de Montbret, 'Essai'; BMR Ms Mbt 872 ; BNF NAF 20080 (Collection Coquebert de MontbretLinguistique 1)

${ }^{249}$ BNF NAF 20080 f.6
} 
the 'idiome du midi' or 'langue d'oc'. ${ }^{250}$ More generally, Charles-Étienne organised his scheme around the distinction between the Langue d'oïl, or as Eugène termed it, 'la langue française proprement dite' and the Langue d'oc, while Eugène, writing before the fall of Napoleon, also concerned himself with the dialects of Italian and German. Finally, and almost as an afterthought, the Coqueberts touched on two languages spoken by members of diasporas resident in France- the Jewish 'dialecte allemande corrompu des mots hébraïque' presumably referring to Yiddish spoken by the Ashkenazi Jewish community in Alsace, and the language of the 'Bohïmans' spoken by Roma communities in Roussillon, Alsace and Lorraine..$^{251}$ Here their attention was far more superficial, and omitted entirely from consideration the Arab populations in Paris and Marseille. For these groups, language became a central buttress of community cohesion, differentiating them from wider French society and reinforcing shared bonds. The community in Marseille, formed from a group of Egyptian refugees who arrived in the city in 1801, was even granted a chair in Arabic at the Lycée in Marseille in $1807 .{ }^{252}$ This omission makes clear that the Coqueberts were above all interested in those groups who might be said to possess a well-defined linguistic territory.

Unfortunately for the historian of linguistics, the Coqueberts never explicitly justified their specific classification of these languages, nor provided a general overview of their method. In his 1812 report Eugène Coquenbert de Montbret talked in rather vague terms about the distinctive 'terms' and 'turns of phrase', the manner in which 'il a en général modifié les mots qui lui ont été transmis par la langue mère dont il est dérivé', and finally the 'terminaisons qu'il emploie de préférence' ${ }^{253}$ Evidence from within the enquiry, however, points to a fairly sophisticated approach to linguistic classification for the period, based on the drawing of what modern linguists would

\footnotetext{
${ }^{250}$ BNF NAF 20080

251 BNF NAF 20080 f.22-3; N. Aston Religion and Revolution in France, 1780-1804 (Basingstoke, 2000) p.253 ;

M. Courthiade, 'Le rromani et les autres langues en usage parmi les Rroms, Manouches et Gitans', in G. Kremnitz (ed.) Histoire sociale des langues de France (Rennes, 2013) p.569

252 I. Coller, Arab France : Islam and the Making of Modern Europe (London, 2011) p.68

253 BNF NAF 20080 f.25
} 
describe as isoglosses- the cartographical line across which a given linguistic feature varies. ${ }^{254}$ This much is clear from the correspondence relating to the arrondissement of Moissac in the Tarn et Garonne, where the sub-prefect sent out a questionnaire asking the mayor of each cantonal capital whether 'le Gascon n'offre-t-il pas plusieurs caractères distinctifs tels que les changements de F en H et de $V$ en $B^{\prime}{ }^{255}$ Both of these features are well known variations that distinguish between Gascon, Castillian and the other Romance languages. ${ }^{256}$ The transition from Latin /f/ to /h/ in Gascon and Castillian subsequently went on to become the subject of a lengthy controversy amongst historical linguists, some of whom attributed the change, somewhat improbably, to the influence of Basque. ${ }^{257}$ Nonetheless, the interest in what is a crucial sound change within Romance linguistics highlights how the Coqueberts, in developing their schema, both heeded the significance of sound change and grounded their work in comparison between languages.

This brings us to the question of where to place the work of the Coqueberts within the history of linguistic thought, and specifically in relation to the genesis of philological understandings of language, a type of knowledge that, as Joep Leerssen rightly reminds scholars of nationalism, has its own history- a history deeply entwined with the development of nationalist thought in the first half of the nineteenth century. ${ }^{258}$ The classical interpretation dates the creation of linguistics as a scientific discipline to the emergence of comparative Indo-European philology in the second decade of the nineteenth century and the works of Jakob Grimm, Rasmus Rask and Franz Bopp. ${ }^{259}$ Above all,

\footnotetext{
254 J.K. Chambers, P. Trudgill, Dialectology (Cambrdige, 1998) p.33

255 BNF NAF 5912 le Maire d'Aurillac au sous-préfet de Moissac f.261

${ }^{256}$ G. Jochnowitz, Dialect Boundaries and the Question of Franco-Provençal (The Hague, 1973) pp.107-12

${ }^{257}$ R. Trask, A History of Basque (London, 1997) pp.424-9; M. Sala, 'Contact and Borrowing', M. Maiden, J.C. Smith, A. Ledgeway (eds.), The Cambridge History of the Romance Languages vol.II: Contexts (Cambridge, 2013) pp.195-7. Not only has the change been replicated elsewhere- notably in southern Italy, where the linguist cannot invoke Basque as an explanation, but the change appears to have taken place after Romance was well established in Castille, without other features of the language reflecting Basque influence, making the theory of a Basque substrate effect unlikely.

258 J. Leerssen, National Thought in Europe: A Cultural History (Amsterdam, 2006) pp.259-60; J. Leerssen, 'Literary Historicism: Romanticism, Philologists and the Presence of the Past', Modern Language Quarterly vol.65 no.2 pp.221-43

${ }^{259}$ H. Aarsleff, Locke to Saussure p.5 ; A. Morpurgo Davies, History of Linguistics vol. iv: Nineteenth Century Linguistics (London, 1992) pp.124-46; R. Harris 'Introduction' in R. Harris (ed.), Foundations of Indo-European
} 
this development emerged from the formulation of 'Grimm's Law', which crucially focused attention on the systematic sound shifts which could be tracked across languages to uncover their shared lineages. ${ }^{260}$ Some scholars of the history of linguistics have dissented from this orthodoxy, bridling at the uncritical acceptance of the claims to scientific rigour and novelty made on behalf of comparative philology, claims generally propagated with greatest enthusiasm by nineteenth century philologists themselves. ${ }^{261}$ Pre-nineteenth century antecedents have been held up to undermine the supposed novelty of the discipline. Turgot's entry in the Encyclopédie is often cited as the earliest prospectus for a historical linguistics based on the study of sounds, albeit one whose potential remained largely unrealised for the following half a century, while others have emphasised the influence of William Jones, who pointed out the common roots of Latin, Greek and Sanskrit in his 1786 lecture to the Asiatic Society, and Conrad Malte-Brun, who coined the term 'Indo-European' in $1810 . .^{262}$

The crucial issue lies rather less with disputes over the details of the intellectual lineage of comparative philology than with the emergence of a new way of producing knowledge about languages and their relationships. Comparative philology was based on the arrangement of languages on a genetic 'family tree' based on the systematic comparison of the features of these languages to determine their mutual affinities, or lack thereof. This was utterly distinct from the older antiquarian approach to etymology, which focused on the history of single words, often through somewhat tenuous unearthing of meaning and dead metaphor. ${ }^{263} \mathrm{~A}$ comparison with the

Comparative Philology 1800-1850 (London, 1999) vol.1 p.2 R.H. Robins, A Short History of Linguistics (London, 1997) pp.189-90

${ }^{260}$ Although this might just as properly be termed 'Rask's Law', as Grimm's formulation in the 1822 edition of his Deutsche Gramatik came only after reading Rask's 1810 prize essay on the etymology of Danish, published in 1820; Harris 'Introduction' pp.5-6 ; Morpurgo Davies, Nineteenth Century Linguistics pp.126, 142-4

${ }^{261}$ Roy Harris talks of the 'propaganda' of comparative philology; Harris 'Introduction' p. 2

${ }^{262}$ Rask cited Turgot's entry in the Encyclopédie approvingly in his 1810 essay on Danish etymology. Harris, 'Introduction' pp.9-11 D. Droixhe, La linguistique et l'appel de l'histoire 1600-1800 : Rationalisme et révolutions positivistes pp.210-15; Morpurgo Davis, Nineteenth Century Linguistics p.126; S. Auroux Linguistique et anthropologie en France, 1600-1800 (Paris, 1982) p.7 ; F.R. Shapiro 'On the Origin of the Term Indo-Germanic', Historiographia Linguistica vol.8 no.1 (1981) pp.165-70

${ }^{263}$ The distinction between 'philology' and 'etymology' would not have been understood in the first decades of the nineteenth century, since the latter term had a far broader acceptation than today. As Morpurgo Davies, 
work of Éloi Johanneau, a contemporary advocate of what he referred to as the 'etymological sciences', is sufficient to draw attention to the gulf separating the Coqueberts from the Antiquarian etymologists. Johanneau was the permanent secretary of the Académie Celtique, and apt to prove the Celtic origins of almost any custom or belief through the application of a generally tenuous etymology. For example, Johanneau was convinced that Saint Geneviève, the patron saint of Paris, was originally an allegorical representation of the moon amongst the Celts:

Geneviève ou Genover(s)a , que les Latins prononçaient Genovers(s)a, signifie en celtique visage terni, décoloré; car Ghenove(s)a est composé des deux mots celtiques, existans encore en Breton et en Gallois, Gheno ou Ghenou, pluriel de Ghen, visage, et Gwev, en construction vev, terni, flétri, décoloré, ridé, pâle, défait, abattu, languissant, triste. ${ }^{264}$ Such etymologies, produced by figures like Johanneau, contrasted markedly with the more systematic, comparative approach adopted by other French scholars of the period. Volney, a prominent ideologue thinker, presented a report to the Académie celtique on Peter Simon Pallas's comparative linguistic dictionary, a work which gathered together a list of 130 common words translated into 200 different languages. ${ }^{265}$ Volney criticised the work, which was subsequently used as a source of data by a number of prominent comparative philologists, on the basis that the Russian alphabet employed by Pallas was inadequate to represent the sounds of the languages in question. Volney's solution was the creation of a universal alphabet, one in which every sound that the human vocal tract could produce would be given a unique symbol, and in this way a systematic phonetic comparison between languages would be possible. ${ }^{266}$ With this proposal Volney displayed an

observes, Rask followed Turgot in talking of 'etymology' in his earlier publications, even as he composed the first interventions in what would later be described as 'philology'. Morpurgo Davies, Nineteenth Century Linguistics p.125

${ }^{264}$ É. Johanneau, 'Rapport lu à l'Académie celtique sur un ouvrage par A. Lenoir' in Mémoires de l'Académie celtique vol.1 no.2 (1807) p.148-9

${ }^{265}$ Volney, 'Rapport fait à l'académie celtique sur l'ouvrage russe de M. le professeur Pallas intitulé : Vocabulaires comparés des langues de toute la Terre', Mémoires de l'académie celtique vol.1 (1807) pp.99135 ; P.S. Pallas, Linguarum totius orbis vocabularia comparativa (2 vols., St Petersburg, 1787-9)

${ }^{266}$ Volney, 'Rapport' pp.123-3 
awareness of the distinction between sounds and alphabets not always evident in the work of Grimm and Bopp. ${ }^{267}$

The Coqueberts, with their emphasis on the comparison of linguistic samples, were closer to Volney's paradigm than to Johanneau's. This is not to make a grandiose claim for their place at the head of a new philological science, even if Eugène himself saw his work in this fashion, claiming it would provide 'des rectifications essentielles à faire dans les ouvrages historiques et philologiques'. ${ }^{268}$ The Coqueberts were simply too unsystematic in the way they set out the principles underlying their linguistic comparisons for their work to be meaningfully described as scientific in the manner of Grimm or Rask, while Linguists such as Roy Harris have questioned whether even the work of the Coqueberts' successors in comparative philology should be considered scientific. ${ }^{269}$ However, their methods did allow them to produce a typology of the linguistic groupings of the Napoleonic Empire, shown in Figure 5, that a modern linguist would recognise.

The basic grouping of languages into Romance and Germanic groups with Breton and Basque as distinct entities remains valid, and also neatly sidesteps the Celtomania, evident in the sixteenth century work of figures such as Leibniz and manifest within Johanneau's etymologies, which would ascribe Celtic origins to the Romance dialects of France. ${ }^{270}$ The Coqueberts drew the classic distinction between Low and High German, although Eugène confessed he possessed insufficient data to distinguish effectively between the complex dialectal zones modern linguists refer to as the Rhenish fan, where the fairly coherent isoglosses separating Low and High German spread out in the Rhineland. ${ }^{271}$ Within the Romance speaking part of France, the distinctions established by Coquebert bear some resemblance to those described by Bernard Cerquiglini in 1999. As part of the European Charter for Regional and Minority Languages, which France signed but never

\footnotetext{
${ }^{267}$ Harris, 'Introduction' p.7

268 BNF NAF 20080 f. 2

${ }^{269}$ Harris, 'Introduction' pp.11-3

270 Droixhe, La linguistique p.210

271 L. Bloomfield, Language (1933) pp.324-31
} 
ratified, the state was obliged to draw up a list of minority and regional languages to which the charters provisions on state support would apply, a task that was delegated to Cerquiglini, the then director of the National Institute for the French Language. ${ }^{272}$ Based on the broad consensus of modern dialectologists, Cerquiglini proposed the following classification ; with a grouping of 'Occitan' languages- Gascon, Languedocien, Provençal, Auvergnat-Limousin, Alpin-dauphinois ; a grouping of 'langues d'oïl' - Franc-comtois, Wallon, Picard, Normand, Gallo, Poitevin-Saintongeais, Bourguignon-Morvandiau, Lorrain and finally Catalan and Françoprovençal as separate entities. ${ }^{273}$

The divergences between the classification established by the Coqueberts' and Cerquiglini's work reflect the transformations in knowledge about the dialects of France wrought by the work of dialectologists in the intervening two centuries. The most obvious differences between the classification established by the Coqueberts and Cerquiglini's 1999 work appear to stem from confusion over the status of Francoprovençal. The Coqueberts' failure to recognise an intermediate Francoprovençal zone led them to group 'Lyonnais' and 'Savoyard' with the northern dialects. Yet the status of these dialects as a distinct zone was only established in the 1870s by the Italian dialectologist Graziadio Ascoli. ${ }^{274}$ The Coqueberts also omitted Norman and Gallo from their list of dialects, despite receiving a response detailing various details of the 'dialects normands' from the prefecture of the Seine Inférieure, and on 'gallau' from the prefect of Morbihan, on the basis that they were too similar to standard French. ${ }^{275}$ As for the southern dialects, the main divergence seems to have been splitting Limousin-Auvergnat into separate entities with the addition of Perigourdin,

\footnotetext{
272 L. Oakes, 'Regional Languages, the European Charter and Republican Values in France Today' in C. Norrby and J. Hajek (eds.), Uniformity and Diversity in Language Policy: Global Perspectives (Bristol, 2011) p. 70; J. Sibille, 'La notion de langues de France, son contenu et ses limites', G. Kremnitz (ed.) Histoire sociale des langues de France (Rennes, 2013) pp.48-52

${ }^{273}$ B. Cerquiglini, Les Langues de France Rapport au ministre de l'Education Nationale, de la Recherche et de la Technologie et au Ministre de la Culture et de la Communication (Paris, 1999) http://www.dglf.culture.gouv.fr/lang-reg/rapport cerquiglini/langues-france.html accessed 18/02/2012 274 Jochnowitz, Dialect Boundaries p.30 ${ }^{275}$ AN F 171209 Sécretaire de la préfecture du Seine Inférieur au ministre de l'intérieur, 31 Jan. 1812 ; BNF NAF 5911 Coquebert de Montbret au préfet du département du Morbihan, 30 Sep. 1808 f.335; Coquebert de Montbret Essai p.24
} 
and including Catalan which is now not considered to be part of the 'Oc' dialect zone. ${ }^{276}$ This must be set alongside the enduring difficulties in drawing up such classificatory schemes. Even the distinction between the langue d'Oc and the langue d'Oil can be controversial. Linguists aligned with the Occitan nationalist movement such as Pierre Bec insist that the dialects of the South of France constitute a coherent whole, a claim that might be seen to buttress political claims for concessions such as state funding for Occitan language schooling. ${ }^{277}$ Others, such as Louis Bayle, have decried a process of 'Occitanisme', claiming that Occitan nationalism effaces 'authentic' regional entities such as Provence, and that it would be more proper to talk of a group of related 'langues d'oc'. 278 Similarly, just as the Coqueberts were undecided about how to define the relationship between Gascon and Occitan, there remains discord over whether the former should be considered a language in its own right or a dialect of the latter.

The question of distinguishing between linguistic varieties, as dialectologists Chambers and Trudgill observe, is in part political, and almost impossible to resolve through recourse to linguistics alone, because of a phenomena that the Coqueberts seem to have been sensitive to, the 'dialect continuum'. For modern linguists, the term dialect continuum refers to the uneven way in which individual linguistic variations are distributed in geographical space, so that a particular word, grammatical form or pronunciation may be shared by speakers in two different locations even as other linguistic features differ. ${ }^{279}$ This is a phenomenon that was obscured by the initial stages of the enquiry, which required only that speakers' language be grouped into abstract notions of languages such as French or German. However, as Eugène Coquebert de Montbret observed, the localisation

\footnotetext{
${ }^{276} \mathrm{H}$. Walter, P. Fawcett (trans.), French Inside Out: The Worldwide Development of the French Language in the Past, Present and Future (London, 1994) p. 102

${ }^{277}$ P. Bec, La langue occitane (Paris, 1963) ; G. Kremnitz, 'Une approche sociolinguistique' in F. P. Kirsch, G. Kremnitz and B. Schlieben-Lange (eds) C. Chabrant (trans.), Petite histoire sociale de la langue occitane: usages, images, littérature, grammaires et dictionnaires (Perpignan, 2002) pp.109-111; Recent debates over the place of regional languages in the French educational system have been hotly contested. See L. Oakes, 'Regional Languages, the European Charter and Republican Values in France Today', C. Norrby, J. Hajek (eds.), Uniformity and Diversity in Language Policy: Global Perspectives (Bristol, 2011) pp.72-5

278 L. Bayle, Procès de l'occitanisme (Toulon, 1975)

279 J.K. Chambers and P. Trudgill, Dialectology (Cambridge, 1998) pp. 6-7
} 
of the various dialectes or patois was difficult because they 'se fondent pour la plupart les unes dans les autres sur leurs confins, et que par conséquent il est assez difficile de reconnaitre le point précis où s'arrête chacun d'eux'.280

Regardless of the uncertainty generated by what was a technically complex process, and one that today remains less than wholly resolved, the Coqueberts forged a vision of the French empire divided territorially into the homelands of linguistically defined ethnic communities. Their territorial divisions of the empire were based on the linguistic affinity of the population, and in defining community as a question of language, rather than will and consent, the Coqueberts took a similar position to comparative philologists such as Jacob Grimm and Rasmus Rask, who viewed language as the most basic feature history. ${ }^{281}$ The typology devised by the Coqueberts was an early example of the kind of phylogenetic family language trees later produced by historical philologists. This classification produced a stark vision of almost intractable linguistic diversity. In only around 25 departments, stretching from the île de France to upper Brittany, could the population be considered wholly Francophone. ${ }^{282}$ These speakers were really only the largest minority within a polyglot empire, as is evident from Figure 6, a map compiled from the Coqueberts' observations, they were surrounded by speakers of the northern Langue d'oil dialects, with the territory of the Langue d'oc to the south, Breton to the west, Flemish, Dutch and German to the east, Italian to the south east and a pocket of Basque speakers in the south west. For the Coqueberts, who viewed the bonds of language as a fundamental property of social life and community identity, this must have appeared as an enormous challenge to the creation and governance of a cohesive state, and it is perhaps unsurprising that they came to view the active pursuit of state language policies as futile. This vision of language as the ultimate determiner of cultural identity would, during the nineteenth century, drive nationalist efforts to remake the political map of Europe in such a way that it might

\footnotetext{
280 BNF NAF 20080 f.3-4.

${ }^{281}$ Harris, 'Introduction' p.7

${ }^{282}$ Coquebert de Montbret, 'Essai' pp.23-4 ; Excluding the departments described as patois speaking by Eugène in 1812 the total number of French speaking departments was 22.
} 
better reflect the linguistic geography of its population, even if such efforts had little impact in France where political separatism was not a prominent feature of regionalist movements. ${ }^{283}$

In seeking to bring a geographical order to the messy linguistic realities they encountered, the Coqueberts produced a linguistic geography that would have been recognised, if not uncritically accepted, by modern dialectologists. On this basis, their work might form a useful starting point for a typology of linguistic minorities within the Empire. Sociolinguists have developed a number of typologies of multilingual contexts, based on a variety of analytical rubrics, in the hope of explaining why certain linguistic minorities abandon their language, while others strive to maintain it and even form political movements agitating for linguistic rights, political separation or independent states. ${ }^{284}$ One paradigm has seen scholars approach the problem in much the same way as the Coqueberts, exploring the issue of language in political space- that is the relationship of linguistic variation in space to the political geography of territorial states. Paul White, in an article on the spatial distribution of linguistic minorities in Italy, has suggested a threefold distinction which he claims might serve to explain the differing trajectories of minority political movements. ${ }^{285}$ Firstly, White draws a distinction between minorities whose language is the majority language of another state, and 'absolute' minorities, the 'nation without a state'. ${ }^{286} \mathrm{~A}$ further contrast is drawn between linguistic minorities present in two or more states, and 'unique' minorities- such as Breton or Welshpresent in only one state. ${ }^{287}$ For minorities present in multiple states, a second important consideration is whether they are 'contiguous' or 'non-contiguous', that is, whether the minorities occupy a continuous territory stretching across a political border, or are geographically isolated. In situations where a linguistic minority borders a country where their language is the majority

\footnotetext{
${ }^{283}$ Although some regionalists did desire independent statehood- R. Gildea, The Past in French History (London, 1994) pp.209-10

${ }^{284}$ For a useful overview of this work see J.E. Joseph, Minority Languages and Group Identity: Cases and Categories (Amsterdam, 2010) pp.73-104

285 P. White, 'Geographical Aspects of Minority Language Situations in Italy', C.H. Williams (ed.) Linguistic Minorities, Society, and Territory (Clevedon, 1991) p.45

${ }^{286}$ White, 'Geographical Aspects' p.46

${ }^{287}$ White, 'Geographical Aspects' p.46
} 
language, White claims that irredentism is a likely outcome, while linguistic separatism may emerge in those contexts where, as with the Catalan minorities in France and Spain, the minority language populations are contiguous across the border of two states where other languages are the majority variety. ${ }^{288}$ Finally, White considers the internal spatial structure of the minority- whether or not groups of speakers are 'diffuse', as with Cornish, or 'close knit', occupying a coherent territory, as with Breton, Welsh, Galician, or a number of other European minorities. ${ }^{289}$

Applying the schema to the Napoleonic Empire would produce a geography not unlike the Coqueberts' own efforts. As the classification developed by the Coqueberts made clear, the primary concern for the French state lay in linguistic groupings with a defined territory, those with a cohesive spatial distribution. In 1806, the only linguistic minority unique to the French state and territorially coherent were speakers of Breton. The majority of Occitan speakers, with the exception of those in the Val d'Aran in Spain, were also located within the Empire. In 1810, with the annexation of the Kingdom of Holland, they were joined by a third, the Flemish and Dutch speakers of Northern France, Belgium and the Netherlands. These groups were joined by three cohesive minorities speaking the majority languages of other states- the German speakers of Alsace, Lorraine and the French Rhineland, the Italian speakers of northern Italy, and the Basque speakers of the South-West, who shared a border with other Basque speakers in Spain. These were precisely, according to White, the kinds of linguistic minorities most likely, by their spatial distribution, to bristle at the rule of a linguistically foreign state. The presence of minorities such as the Germans of the Rhineland or the Italians in Northern Italy are, according to White, likely to lead to irredentism, while groups such as the Basque speakers, matched by a neighbouring minority speaking the same language, are likely to agitate for their own state. ${ }^{290}$ In comparison, the immigrant and diaspora languages of France, which were either cited in only a perfunctory manner or omitted entirely by the Coqueberts, can by their nature, exercise little influence on the political geography of a region, even as they remain crucial

\footnotetext{
${ }^{288}$ White, 'Geographical Aspects' p.47

289 Ibid., p.48

290 lbid., p.49
} 
loci of identification for individuals within the community. For the Coqueberts, therefore, as for the romantic nationalists and philologists who shared their approach to the classification of linguistic groupings, the significance of a language rested on its identification with a well-defined territory.

\section{Community and Place: An Ethnographic Approach}

The difficulty with the kind of geographic typology elaborated by the Coqueberts was that the distinctions they drew between languages were far from universally accepted by their contemporaries. This reflects a weakness in the geographical approach to linguistic classification identified by modern linguists. While the geographic approach, much like the approach adopted by the Coqueberts, begins with a classification of languages along formal lines of grammatical structure and syntax, and then seeks to explain the attitudes and behaviours of speakers with relation to their shared linguistic affinity and spatial distribution, most typologies of multilinguistic contexts make ample space for ethnolinguistic data- for the subjective attitudes and practices of speakers. ${ }^{291}$ While linguists seeking to categorize a given linguistic context would doubtless gather data on the formal classification and spatial distribution of a language, as well as the attitudes of its speakers, this is in a sense to tackle the problem in two opposed fashions- to move from a model positing a linguistic explanation of culture, to one in which language itself as a category is constructed through culturethrough the attitudes of speakers. The latter position is associated with the anthropologist Dell Hymes, who sought to move beyond formal linguistics by studying language as one part of a broader communicative culture. Hymes observed that formal linguistic classification was often a rather poor guide to the way speakers defined the limits of their communities. In some instances, communities would strive to maintain communication even across relatively large formal disparities in dialect, while others would declare their varieties to be mutually unintelligible on the basis of a relatively

${ }^{291}$ Edwards, Minority Languages p.82 
slight differentiation. ${ }^{292}$ Hymes' claims are reinforced by findings from folk linguistics, and in particular from perceptual dialectology, where folk definitions of the dialect boundaries seem to correspond as frequently with political boundaries as with the isoglosses on a dialectologists' map, often to the chagrin of dialectologists themselves. ${ }^{293}$

This was precisely the difficulty encountered by the Coqueberts, for where they organised languages according to their formal linguistic features, the overriding impression created by the profusion of correspondence from disparate parts of the empire was of a highly fragmented linguistic reality, and many of their correspondents emphasized the particularity of the local patois. Liandier, director of the secondary school in the commune of Saint-Flour in the Cantal, was typical, claiming that 'le patois usité dans les diverses parties de votre arrondissement, monsieur le souspréfet, varie non seulement d'un canton à l'autre, mais encore de commune à commune; il n'est pas le même dans deux villages voisins, dans tous les quartiers de la même ville' ${ }^{294}$ The refrain was echoed by the prefect of the Herrault who claimed the language of the countryside varied 'dans les différens arrondissemens' ${ }^{295}$ Similarly, according to the sub-prefect of Riom, in the Puy-de-Dôme 'I'idiome de notre pays' was characterised by 'dialects [ou] variations [qui] sont multipliés presque à I'infinité'. ${ }^{296}$ A similar linguistic tapestry was described by the prefect of the Rhin et Moselle, one of the Rhenish departments annexed in 1798 and now part of Germany, who provided the Coqueberts with three different translations of the parable in 'le langage du peuple' which, he claimed, varied 'presque de village en village'. ${ }^{297}$ The general secretary of the prefecture of Montenotte, in northern Italy, observed that there was a very notable difference between the arrondissements of Savone and Port-Maurice, which were formed from Liguria, and those of Acqui and Ceva, formed from Piedmontese territory. The linguistic diversity did not end there, however, for as the secretary

\footnotetext{
292 D. Hymes, Foundations in Sociolinguistics: An Ethnographic Approach (Philadelphia, 1974) p.31

293 D.R. Preston, Perceptual Dialectology : Non-Linguists' Views of Areal Linguistics (Philadelphia, 1989) p.12

${ }^{294}$ BnF Naf 5910 Liandier, Directeur de l'école secondaire communale de Saint-Flour to sous-préfet de l'arrondissement 12 Sept. 1808

295 BnF Naf 5912 Nogaret, Préfet de l'Hérault to Ministre de l'intérieur 25 Feb. 1812 f.125

${ }^{296}$ An F 171209 Sous-Préfet de Riom to Ministre de l'intérieur 10 Feb. 1808

${ }^{297}$ BnF Naf 5912 Préfet de Rhin et Moselle to Ministre de l'intérieur, 6 Dec. 1808 f.111
} 
observed, 'Il est assez naturel de penser que les communes limitrophes des arrondissemens ligurien et piémontais font usage d'un patois mixte qui tient de tous les deux'. ${ }^{298}$

The assertions of intractable linguistic diversity with which the correspondence solicited by the Coqueberts abounded demonstrates above all that the Coqueberts' organization of linguistic space was not the only, nor even perhaps the most significant, geography of language available to contemporaries. As Lacoste, a member of the Société d'agriculture, sciences et arts d'Agen remarked of the dialects of the Lot et Garonne:

On prétend remarquer des différences dans le langage des habitans d'un quartier, d'une même ville, avec celui des habitans d'un autre quartier. Cela paroit exagéré ; mais ce qui est bien démontrée; c'est qu'il n'y a pas deux bourgs ou villages qui ayent [sic.] absolument le même idiome. La différence n'est pas très sensible, pour autres que les individus qui y résident ; mais elle est réelle. ${ }^{299}$

It seems Lacoste was gesturing towards a different way of understanding the linguistic tapestry of the French population, and one not necessarily grounded in the firm linguistic boundaries sought by the Coqueberts but in more subtle distinctions that mattered in the mental geographies of contemporaries. It is striking that few correspondents seemed to consider mutual comprehension a significant criteria for the delimitation of linguistic communities. As the prefect of the Stura wrote of the dialects of Piedmont, 'quoiqu'il en soit les habitans d'une province quelconque entendront toujours le langage de toutes les autres avec cette restriction qu'ils savent dire que celui qui parle est de telle ou telle autres partie du Piémont'. ${ }^{300}$ Rather, local distinctions were of great importance, a sentiment expressed by the sub-prefect of the arrondissement of Suze, which incorporated some of the French speaking areas of the west of the department of the Pô. As he wrote,

ce qu'il y a de plus remarquable, c'est que ce patois varie assez d'une commune à l'autre que les gens du pays distinguent sans peine, non seulement les habitans [sic.] d'une commune avec ceux de la commune voisine, mais ils reconnaissent encore à ne pas s'y tromper les habitans [sic.] de deux hameaux séparés l'un de l'autre d'un jet de pierre, et ne

\footnotetext{
${ }^{298}$ BnF Naf 5911 Secretaire général de la préfecture de Montenotte au Ministre de l'intérieur, 27 Nov. 1808 f.339

${ }^{299}$ BnF Naf 5911J.J. Lacoste, Essai sur les diverses dialectes du dépt. Du Lot et Garonne, Oct. 1807 f.252

${ }^{300}$ BnF Naf 5912 Préfet de la Stura au Ministre de l'intérieur, f.217
} 
formant entr'eux qu'une seule et même commune. Cette différence ne consiste pas seulement dans celle de l'accent et de la prononciation, il en est une aussi réelle dans un partie des mots dont ils se servent. ${ }^{301}$

Later in the nineteenth century, when conducting fieldwork in the fishing village of Saint-Cast on the northern coast of Brittany, Paul Sébillot found that, when telling a story that involved the inhabitants of nearby Saint-Jacut, the Câtin fishermen would adopt a humorous accent and bizarre turn of phrase to ridicule their neighbours, a common technique amongst storytellers across France during the nineteenth century, and one demonstrating that local rivalries determined contemporaries' assertions of linguistic difference as frequently as the lines on a dialectologists' map. ${ }^{302}$

The patchwork complexity of these subjective geographies was revealed in part by the geographical distribution of the dialect translations collected by the Coqueberts. The Coqueberts received more than 300 versions of the parable of the prodigal son, and this was in part because their correspondents were eager to demonstrate the variability of local speech. Some of the versions were intended to represent a broadly defined linguistic variety, such as the text in 'Patois Gascon' from the Gers, or the version in 'vers piémontais' from the Pô. ${ }^{303}$ Other translators took national political boundaries as the point of departure- thus the Coquebets collected versions in the 'Basque de France' and the 'Basque d'Espagne'. ${ }^{304}$ Some correspondents organised linguistic space in accordance with the commonplace distinction between the mountains and the plains. ${ }^{305}$ From the Vosges, for example, the Coqueberts received versions in the 'patois des montagnes' and the 'patois du plat pays' ${ }^{306}$ However, by far the most frequently employed distinction was between the speech of two closely defined local areas. For example, the Coqueberts received a 'traduction en patois du

\footnotetext{
${ }^{301}$ BnF Naf 5912 Sous-préfet de Suze, Rapport sur les différents dialectes usités dans l'arrondissement de Suze, département de Pô, f.18

302 D. Hopkin, Voices of the People in Nineteenth Century France (Cambridge, 2012) p.74

${ }^{303} \mathrm{BnF}$ Naf 5911 (Patois de la France I- Ain-Eure)Deuxième échantillon du patois gascon. Traduction dans le dialecte de ce patois, qui étoit en usage dans le dix-huitième siècle, de la parabole de l'enfant prodigue ff.412 ; BnF Naf 5912 Paràbola di fient prodigh st luc cap xv vers 11 ad 37 incl. tradotta an vers piemonteis, ff.26-9 ${ }^{304} \mathrm{BmR}$ Ms Mbt 489 Langue basque- la parabole de l'enfant prodigue ff.4-5

305 Merle, Visions pp.50-1

${ }^{306}$ An F 171209 Vosges, parabole de l'enfant prodigue, patois des montagnes, parable de l'enfant prodigue, patois du plat pays.
} 
canton de Mayet' in the Allier, a version 'en langage vulgaire des environs de Marennes' from the Charente Inférieur, and from the Gironde, a translation 'en l'idiome le plus usité dans le canton de Blaye' ${ }^{307}$ No fewer than 290 of the translations received by the Coqueberts were explicitly linked to a locale in this fashion, referencing 268 distinct locations.

For the most part, the production of these translations reflected the linguistic distinctions drawn by the local elites who carried them out. These distinctions were manifest in the multiple versions drawn up for many administrative divisions. The Coqueberts began their enquiries in each department with a letter to the prefect, asking for information on the area within which each variety was spoken and asking for translations of the parable in these varieties. Of the 268 parables explicitly situated in geographic space, only 107 were intended to represent the speech of an arrondissement or its chef-lieu, with 108 related to a cantonal chef-lieu and 51 to communes or town quarters with no larger administrative function. Rather, the profusion of translations reflected the tendency of locals to draw fine distinctions between the speech of geographically proximate groups, defining the limits of linguistic communities on the basis of local social distinctions. The correspondent from the Bains in the department of the Vosges complained that one translation was inadequate to convey the linguistic diversity of this single commune, let alone the canton as a whole. As he explained, 'les ouvriers de la manufacture de M. Falatun et les habitans des hameaux et des fermes isolées qui font partie de cette commune ont un langage, qui en bien des points s'écarte déjà de celui des habitans de Bains mêmes'. ${ }^{308}$

Contemporaries, therefore, were quick to draw linguistic distinctions on the basis of subjective constructions of social reality, and these constructions were often grounded in very local distinctions and rivalries. Probably the clearest example of this uncertainty emerged from the Coqueberts' attempts to distinguish between the Langue d'oc of the south and the Langue d'oïl of

\footnotetext{
${ }^{307}$ BnF Naf 5910Parabole de l'enfant prodigue, traduction en patois du canton de Mayet, f.38 ; Traduction en langage vulgaire de environs de Marennes de la parabole de l'enfant prodigue, ff.239-40 ; BnF Naf 5911 Souspréfet de Blaye to Ministre de l'intérieur, 26 Mar. 1810 f.72

${ }^{308}$ An F 171209 Bains, Notes sur la traduction ci-jointe du chapitre XV de l'Evangile selon St. Luc.
} 
the north, an effort examined in detail by Guylaine Brun-Trigaud in her doctoral thesis on the elaboration, by nineteenth century dialectologists, of the metaphor of a linguistic 'croissant' to describe the distribution of intermediary speakers along this boundary. ${ }^{309}$ As Brun-Trigaud suggests, the notion of a linguistically distinct south does emerge from the correspondence- the idea was more than the Coqueberts' imposition on the material they gathered. ${ }^{310}$ The sub-prefect of Montélimar, for example, claimed that his commune marked the transition to a distinctive patois derived from Latin and Italian, spoken all the way to Montpellier and Marseille. ${ }^{311}$ Yet this assertion of linguistic alterity plainly did not reflect a well-defined or widely diffused 'Occitan' linguistic identity. Indeed, the sub-prefect identified it only through its relationship to Latin and Italian, rather than as a 'Langue $d^{\prime} O c^{\prime}$. Moreover, the sub-prefect was not even sure the language possessed a unified territory across which it provided a common medium of communication, claiming that the language varied from commune to commune to such an extent that 'il en est si peu de même en remontant qu'un habitant de Montélimar est embarrassé pour soutenir une conversation en patois avec un cultivateur de Valence' ${ }^{312}$

According to Brun-Trigaud, the first assertion of the linguistic distinctiveness of the south in the correspondence gathered by the Coqueberts was made in May 1807 by the sub-prefect of Confolens in the Charente. ${ }^{313}$ Yet this distinction was drawn not between the languages of the north and south of France, but between varieties of speech that the sub-prefect connected to the old political boundaries of the regions of Poitou and the Limousin: 'On connait dans cet arrondissement deux idiômes vulgaires, ou plutôt, deux patois, le Limousin et le Poitevin'. ${ }^{314}$ In 1812, the prefect of the Charente invoked the older political geography of France- the regions replaced by the

\footnotetext{
${ }^{309} \mathrm{G}$. Brun-Trigaud, Le croissant : Le concept et le mot, contribution à l'histoire de la dialectologie française au XIXeme siècle (Lyon, 1990) pp.41-82

${ }^{310}$ Brun-Tirgaud, Le Croissant p.42

${ }^{311}$ BnF Naf 5910 Sous-Préfet de Montélimar to Préfet de la Drôme 2 Dec. 1807 f.348

${ }^{312}$ BnF Naf 5910 Sous-Préfet de Montélimar to Préfet de la Drôme 2 Dec. 1807 f.348

${ }^{313}$ Brun-Trigaud, Le Croissant p.42

${ }^{314}$ BnF Naf 5910 Sous-préfet de Confolens au Ministre de l'intérieur, 30 May 1807 f.203
} 
departments during the Revolution- to explain the distribution of linguistic varieties, even if the correspondence was not always definitive. As he wrote,

on trouve deux patois ou dialectes dans l'arrondissement de Confolens ; l'une dérivé du patois Limousin, est usitée sur tout le territoire qui, par la division de la France en départemens [sic.], fut distraite de l'ancienne généralité de Limoges et sur un petit nombre d'autres qui appartenaient à la petite province d'angoumois. ${ }^{315}$

The prefect was reiterating the view that the departments had cut across boundaries that reflected more readily the cultural identities and practices of the population. This observation did not necessarily amount to a critique of the new administrative boundaries, since the explicit intention of their revolutionary authors had been to efface the provincial ties that might fragment local loyaltiesto 'melt the various peoples of France into a single people, the various provinces into a single empire', as the Abbé Sièyes claimed. ${ }^{316}$ Nor is it to claim that the distinction drawn by the subprefect of Confolens was linguistically arbitrary. The arrondissement is located on the cusp of the transitional crescent between northern and southern dialects. ${ }^{317}$ As Brun-Trigaud observes, many of the geographies presented by those responding to the Coqueberts were surprisingly proximate to those drawn by modern linguists later in the nineteenth century. ${ }^{318}$ The recourse to these older political boundaries, however, reveals how the organisation of linguistic space pursued by the Coqueberts was not the only frame through which linguistic diversity was understood by contemporaries, something underscored by the sub-prefect of Confolens himself when, after having indicated the linguistic boundary running across his arrondissement, he returned to the trope of a highly variegated linguistic tapestry, claiming that 'chaque localité employe exclusivement certaines expressions, [...] qui lui sont propres. La différence est plus sensible quant à la prononciation; elle est surtout marqué quant à l'accent' ${ }^{319}$ The definition of linguistic community, it seems, had a

\footnotetext{
${ }^{315}$ BnF Naf 5910 Préfet de la Charente au Ministre de l'intérieur, 30 Mar. 1812 f.186

${ }^{316}$ Cited in T. Margadant, Urban Rivalries in the French Revolution (Oxford, 1992) p.94 ; On the formation of the departmental system see M.-V Ozouf-Marignier, La formation des départements : La représentation du territoire français à la fin du $18^{e}$ siècle (Paris, 1989) ; Ozouf-Marignier et. al. Atlas de la Révolution ${ }^{317}$ Brun-Trigaud, Le Croissant p.330

318 Ibid., p.81

${ }^{319}$ BnF Naf 5910 Sous-préfet de Confolens au Ministre de l'intérieur, 30 May 1807 f.203
} 
tendency to drift away from the linguistic boundaries charted by dialectologists when these boundaries did not correspond to the distinctions that were relevant to contemporaries.

Most strikingly, the Coqueberts' demands for information on the linguistic geography of an area often seem to reveal local urban rivalries. In the lengthy response drafted by Liandier, the Auvergnat schoolteacher also cited by Brun-Trigaud as formative in the Coqueberts' search for the Oc-Oïl boundary, the author described phonetic differences between the language of Saint-Flour, and that spoken in the neighbouring départements. ${ }^{320}$ These differences, claimed Liandier, meant the town should be placed on the line separating 'les lieux où la langue des gallo-romains s'est le mieux conservée, de ceux où elle s'est presque entièrement perdue : elle a dégénéré, par exemple, dans les provinces que nous avons au nord, au point de n'offrir presque aucun trait de famille'. ${ }^{321}$ Liandier's subsequent claim that 'on distingue le peuple de Pierrefort du peuple de Ruynes [Ruynesen-Margeride] par son langage autant que par son costume', not only underscored the highly localised scale on which contemporaries understood language to differ - the two communes are around 25 miles apart - it also demonstrates the importance of language as a marker of local difference, a shibboleth distinguishing speakers of different villages or cantons. ${ }^{322}$ Perhaps more significantly, the Latinate pride in Liandier's distinction between the language of Saint-Flour and the areas to the north, denigrated by the teacher as 'degenerate', points towards the importance of place, and of local rivalries, in the formulation of linguistic geographies and the assertion of linguistic difference- that is to say, in the process of identifying with a given body of speakers in contradistinction with a second group.

Nine months after receiving Liandier's information, the Coqueberts wrote to the prefect of the Haute-Loire. They outlined the claims of the schoolteacher from Saint-Flour, but could see no substantial difference between the languages from the samples Liandier had sent them, claiming

\footnotetext{
${ }^{320}$ Brun-Trigaud, Le croissant pp.46-9

${ }^{321}$ BnF Naf 5910 Liandier, Directeur de l'école secondaire communale de Saint-Flour to sous-préfet de I'arrondissement 12 Sept. 1808

322 lbid.
} 
both appeared to belong 'à la langue d'oc qui avec beaucoup de variations se parle dans tout le midi de la France' ${ }^{323}$ However, Jean-Joseph Croze, the sub-prefect of the arrondissement of Brioude, which bordered Saint-Flour, reiterated Liandier's claims:

La différence est [...] très remarquable entre le patois de l'arrond. de Brioude et celui du département du Cantal, mais principalement dans la partie de St. Flour[...] Le langage du Cantal est un compoté d'italien et de patois languedocien, un grand nombre d'expressions semble dériver de la langue Latine. ${ }^{324}$

The sub-prefect corroborated Liandier's linguistic geography but had a very different sense of the relative merit of each language. According to Croze, the language of Saint Flour deserved esteem for its similarity to Latin, 'mais il n'en est pas de même pour la prononciation; elle est dure, trainante très criarde et affecte d'une manière désagréable les personnes qui n'y sont pas habituées' ${ }^{325}$ Croze, like Liandier, emphasised the difference between the languages of the two areas, and in doing so manifested an unmistakeable local pride. Perhaps the language spoken in Saint-Flour was closer to Latin, but it was also unpleasant to listen to, unlike that of Brioude.

Such expressions of attachment to the local municipality through praise for the aesthetic qualities of its speech were echoed by other commentators. Following the publication of his Statistique du département des Bouches du Rhône in 1821, Christophe de Villeneuve received a letter rebuking the prefect for his description of the town of Arles. ${ }^{326}$ According to the author of this anonymous text, the citizens of Arles were dissatisfied with much of Villeneuve's article on the townfrom his description of the inhabitants to derogatory comments about their livestock, and this discontent embraced his account of the commune's speech. In his Statistique, Villeneuve had described the language of Arles as closer to Latin than any other part of Provence, a characteristic that recalled, along with the allegedly aquiline features of the townspeople, the power of Rome. ${ }^{327}$ Yet even this represented an inadequate panegyric for his demanding local readership, since 'les

\footnotetext{
${ }^{323}$ BnF Naf 5912 Ministre de l'intérieur au Préfet de la Haute-Loire 31 Mar. 1809 f.220

${ }^{324}$ BnF Naf 5912 Croze, Sous-Préfet de Brioude au Ministre de l'intérieur 28 Feb. 1809 f.222

325 Ibid.

${ }^{326}$ AdBdR 6 M 1601 (Statistique Villeneuve- Monographs des communes) Arles

327 Villeneuve Bouches du Rhône i, p.899
} 
Arlésiens auroient peut être souhaité qu'on ajoutât que leur idiome est sans contredit le plus doux et le plus agréable de la Provence' ${ }^{328}$ Such elaborate praise, continued the affronted commentator, was only proper given the qualities of a dialect that 'quelques personnes vont jusqu'à le préférer au patois de Montpellier'. ${ }^{329}$ Such rivalry was also evident between much smaller settlements. According to the sub-prefect of the arrondissement of Suze, in the department of the Pô, the inhabitants of the canton of Villar-Almase were renowned for speaking 'le plus mauvais barragoin' ${ }^{330}$ The translator of the version of the parable for Sapois, in the south of the canton of Saulxures, which formed part of the arrondissement of Remiremont, justified the translation on the grounds of the distinctively rustic character of the language spoken there. As he wrote, 'ce patois est le plus rude de la sud de Remiremont et un habitant du Saulxures a [sic.] peine à comprendre un de Sapois qui s'exprimerait dans toute la rudesse de son patois'. ${ }^{331}$

The urge to place the speech of the locality at the top of a hierarchy demonstrating its superiority over neighbouring varieties reflected the intensification of municipal rivalries as a result of the administrative reforms and civic politics of the Revolutionary and Napoleonic period. The Revolution had witnessed a near total reconstruction of the administrative and judicial institutions of the French state. With the new organization of the national territory into departments and districts (later arrondissements), the siting of local civic institutions and judicial authorities suddenly became uncertain, precipitating a deluge of disputes and conflicts between urban centres vying to secure a place as capital of a department or district. ${ }^{332}$ Success in these struggles meant not only the prestige such a status could convey on the urban population, but a raft of offices for the local bourgeoisie in the prefectural institutions and law courts established in departmental and district capitals, and was understood by contemporaries as essential to the economic vitality of towns and

\footnotetext{
${ }^{328}$ AdBdR 6 M 1601

${ }^{329}$ AdBdR 6 M 1601

${ }^{330}$ BnF Naf 5912 Sous-préfet de Suze, Rapport sur les différents dialectes usités dans l'arrondissement de Suze, département de Pô, f.18

${ }^{331}$ An F 171209 Traduction de la parable de l'enfant prodigue, Sapois, canton de Saulxures

332 Margadant, Urban Rivalries pp.107-10 ; Ozouf-Marignier, formation des départements p.292
} 
bourgs. ${ }^{333}$ This urban bourgeoisie comprised precisely the types of local office holding notables who provided the Coqueberts with information on the linguistic diversity of the French population. These figures, as Ted Margadant observes, were firmly rooted in local social and economic structures, frequently holding land as well as offices. ${ }^{334}$ Liandier and Croze were two examples of such local figures. The former, while born in the Haute-Loire, spent most of his adult life as a canon and then a teacher in Saint-Flour. ${ }^{335}$ The latter, while elected several times as deputy to the conseil de cinq cents, was born and later died in Brioude, working within the municipal administration of the town during the Revolution before his appointment as sub-prefect under Napoleon. ${ }^{336}$ The examples of Liandier and Croze point towards a group of local notables and officials with quite local horizons who expressed pride and loyalty towards their hometowns through reference to the local language.

These kinds of distinctions were not confined to the territory of 'old' France, but found expression across the Empire. In the department of the Apennins in Northern Italy, it was claimed that the language followed the influence of the principle cities of the pre-revolutionary political order:

Ce langage en général tient son origine des villes plus considérables que les habitans [sic.] avoisinent, et par conséquence ceux de l'arrondis. de Chiavari à l'ouest ont contracté l'accent de la langue de Gênes; ceux de l'arrondt. de Sarzane à l'est commencent de [mot illisible] l'accent Toscane et ceux de l'arrondt. de Borgo-Taro celui de Plaisance et de Parme. ${ }^{337}$

Similarly, in the Walloon speaking Belgian department of the Sambre et Meuse, Louis Dewez, a native of Namur exercising the position of sub-prefect in the arrondissement of St. Hubert, furnished

\footnotetext{
${ }^{333}$ Margadant, Urban Rivalries pp.111-6

334 Ibid., p.117

335 P. Chassang, Le grand séminaire de Saint-Flour (Saint-Flour, 1994) p.60

${ }^{336}$ A. Robert, E. Bourloton and G. Cougny, Dictionnaire des parlementaires français, depuis le 1er mai 1789 jusqu'au 1er mai 1889 vol.2 (Paris, 1889) p.227

${ }^{337}$ BnF Naf 5910 Observations sur les dialectes du département des Apennins f.100
} 
a dictionary of dialect words in which he made frequent comparisons between his home town and his current residence. ${ }^{338}$

The panoply of very local linguistic distinctions that emerged from the Coqueberts' enquiry reflected the paroxysms of municipal disputes unleashed by the revolutionary reorganization of territory. The market town or local bourg vying for recognition as capital of a canton or arrondissement was the primary focus for the organisation of linguistic space by contemporaries. Not only did cantonal or arrondissement capitals make up the majority of the explicitly named translations, accounting together for 215 of them, but a large number of the communes named had been capitals of cantons before the re-organisation of the departmental system in $1801 .^{339}$ This was in marked contrast to the other possible frames through which contemporaries might have understood linguistic geography. Neither the department nor the old provinces seemed to carry much weight in the production of translations of the parable. Of the departments, only the HautesPyrénées received its own version, while Poitou, Gascogny and Lorraine were the only provinces cited as the basis of a translation. ${ }^{340}$ Nor was the pre-Revolutionary diocese an important consideration. Perhaps surprisingly, given the large number of clergy who carried out translations, the diocese was rarely evoked. Only in Brittany, where translations of the parable in the dialects of Tréguier and Saint-Pol de Léon, two of the old episcopal seats until the Revolution, do diocesan boundaries appear to have influenced the production of translations, and here the importance of these boundaries was such that they continue to structure the way speakers of Breton understand the linguistic geography of lower Brittany. ${ }^{341}$ Elsewhere, diocesan boundaries were mentioned only

\footnotetext{
${ }^{338}$ BnF Naf 5912 Dictionnaire des vieux mots conservé ou altéré dans les différentes dialectes du département de Sambre et Meuse ff.156-9

339 Using the online database of administrative organization, http://cassini.ehess.fr/cassini/fr/html/index.htm I have identified 11 communes that both received translations and had been cantonal capitals. A further 17 towns that were cantonal captials during the period had been capitals of a district before their abolition and replacement with arrondissements in 1801 .

${ }^{340}$ The version of the parable for the Hautes-Pyrnénées is missing- only the letter announcing its translation remains. BnF Naf 5912 Secrétaire général de la préfecutre des Hautes-Pyrénées to Ministre de l'intérieur, 10 Apr. 1808.

${ }^{341}$ J.-F. Legonidec, 'Parable de l'enfant prodigue mise en Breton, dialecte de Léon', Mémoires de l'académie celtique vol.2 (1808) pp.118-26; J. Le Brignant, 'Le même parable, traduite en Breton, dans le dialecte de
} 
once in the correspondence, in the department of the Gers, where the prefect claimed that the inhabitants of the former diocese of Lombez pronounced definite articles in a way that distinguished them from the rest of the department. ${ }^{342}$ The correspondence gathered by the Coqueberts, therefore, shows the importance of drawing linguistic distinctions in the process of place making and local identification. Just as the studies carried out by perceptual dialectologists reflect the importance of political boundaries in the way speakers understand geographies of linguistic diversity, so the linguistic distinctions drawn by those responding to the Coqueberts reflected the significance of local municipal identity that also emerged in the urban rivalries of the Revolutionary period. For many of the local notables from whom the Coqueberts drew their informants, the salient organisation of space was not the large linguistic blocs derived from the comparison of samples, but the far more closely circumscribed local horizons within which competition for distinction and office took place.

\section{Geographies of Language and Society: The Two Frances}

The reticence of the Coqueberts' informants to understand linguistic diversity in terms of the large and homogenous cultural groupings studied by the Coqueberts themselves is not to deny the existence of very real linguistic differences, but simply to observe that these differences manifested themselves within speakers' metalinguistic subjectivities in a variety of ways. Contemporaries constructed their own ideas of linguistic community in divergent fashions, underscoring the dangers of assuming that linguistic difference in itself is a sufficient basis for linguistic identity. Rather, linguistic identity was socially constructed, shaped by the strategies and sentiments of speakers.

Yet over the course of the nineteenth century the Coqueberts' arrangement of the linguistic territory they studied was embraced by many of those, from philologists to social reformers, who turned their gaze towards language. Already in 1803, Antoine Fabre D'Olivet had published his Le

Tréguier', Mémoires de l'académie celtique vol.2 (1808) pp.127-31; F. Broudic Parler Breton au XIXe siècle : Le nouveau sondage TMO régions (Brest, 2009) pp.123-7

${ }^{342}$ BnF Naf 5911 Préfet de Gers to Ministre de l'intérieure, 10 Feb. 1808 f.34 
Troubadour: poésie occitanique. The adjective 'occitanique' was, according to Olivet, 'A new word, adopted to express at once Provençal, Languedocien, and generally all the dialects derived from the ancient Langue $\mathrm{d}^{\prime} \mathrm{oc}^{\prime} \cdot{ }^{343}$ In the following decades, under the growing influence of philology, there were a number of attempts to categorise groups of people based on the comparison of language. In his 1826 Atlas éthnographique du globe, for example, Adriano Balbi explicitly embraced linguistic comparison as a way of arranging the nations of the world on a genetic family tree, drawing on Pallas' linguistic dictionary as his source base. ${ }^{344}$ In 1840, J.F. Schnakenberg's Tableau synoptique et comparatif des idiomes populaires de la France followed the Coqueberts both in using the parable of the prodigal child as the documentary basis of linguistic comparison between the dialects of France, and in arranging these varieties according to the distinction between the northern Langue d'oil and the southern Langue d'oc. ${ }^{345}$

The north-south divide also became a prominent feature in the work of social reformers who advocated state action of a type the Coqueberts came to regard as futile. In the context of France and the division between the north and south, social difference usually meant social backwardness. Probably the best known nineteenth century elaboration of the north-south divide was the work of Louis Maggiolo. In 1879-80, Maggiolo conducted studied historical literacy rates across France, based on the number of people who signed their name in the parish marriage records, as opposed to marking a cross, as an indicator for literacy. ${ }^{346}$ On the basis of this data, Maggiolo cleaved the territory of France in two, with a line running from St. Malo in the north east, down to Geneva separating the north east, where literacy rates were high, from the south and west, were they were far lower. This Maggiolo line encouraged contemporaries to distinguish between two Frances,

\footnotetext{
${ }^{343}$ F. d'Olivet, Le Troubadour : Poésie Occitanique du XIlle siècle (4 vols., Paris, 1803) i. 1 ; P. Martel, 'The Troubadours and the French State in D. Van Hulle and J.T. Leersen (eds) Editing the Nation's Memory : Textual Scholarship and Nation-Building in Nineteenth Century Europe (Amsterdam, 2008) p.199

${ }^{344} \mathrm{~A}$. Balbi, Introduction à l'atlas ethnographique du globe (Paris, 1826) pp.ix-xiv; A. Lamelli, 'Lingusitic Atlases, Traditional and Modern', Language and Space: An International Handbook of Linguistic Variation vol.1: Theories and Methods (Berlin, 2010) p.571; On Balbi's geographic work see A. Godlewska, Geography Unbound: French Geographic Science from Cassini to Humboldt (London, 1999) pp.222-32.

345 J.-F. Schnakenberg, Tableau synoptique et comparatif des idiomes populaires de la France (Berlin, 1840)

${ }^{346}$ Furet and Ozouf, Reading pp.3-10
} 
populated by two distinct civilizations- the enlightened France of the north, and the backwards south.

Maggiolo's line from Saint-Malo to Geneva did not reflect the linguistic diversity of the population of France. Using the catalogue of versions of the parable compiled by Marie-Rose SimoniAurembou as a starting point, the distribution of these translations can be plotted on a map of the Empire, given in Figure 7.347 As this map demonstrates, the linguistically more distinct areas embraced the Coqueberts' task with the greatest alacrity. Certainly, as Simoni-Aurembou observes, the southern langue d'oc speaking departments furnished a large number of translations. ${ }^{348}$ As Figure 7 shows, the Franco-Provençal and Langue d'oïl dialects of Eastern and North-Eastern France, and the German, Dutch and Flemish varieties in the northern Rhenish and Belgian departments were also well represented. As this chapter has demonstrated, the completion of translations reflected more than the Coqueberts' interests. Informants often composed versions to illustrate the linguistic differences they felt were pertinent. On this basis, it is clear that the issue of linguistic difference was not confined either to the south, or to the regions grouped below Maggiolo's line.

Nonetheless, a persistent strand within French social commentary identified linguistic difference with social backwardness. As Roger Chartier has observed, the distinction drawn by Maggiolo between enlightened and backward France had a long history. ${ }^{349}$ In 1826 , Charles Dupin published the very first chloropleth map (a thematic map where regions are shaded to show a statistical variable), showing the rates of school attendance across France. These maps, according to Dupin, revealed linguistic difference as an enduring obstacle to social progress: 'Vous serez frappés

\footnotetext{
${ }^{347}$ M.-R. Simoni-Aurembou, 'La couverture géolinguistique de l'Empire français : L'enquête de la parabole de l'enfant prodigue', Espaces romans vol.2. Simoni-Aurembou provides a map of the responses by department, but omits entirely the responses from Finistère. Her list also required referencing against the manuscript material, as some place names of smaller towns were displaced by larger neighbouring settlements- for example, a translation in the dialect of the village of Sapois in the Haut Rhin was listed as the cantonal cheflieu, Saulxures, by Simoni-Aurembou. AN F 171209 Sapois, Canton de Saulxures, traduction de la parable de l'enfant prodigue

${ }^{348}$ Simoni-Aurembou, 'couverture géolinguistique' p.131

${ }^{349}$ R. Chartier, 'The Saint-Malo Geneva Line', P. Nora (ed.) A. Goldhammer (trans.) Realms of Memory : The Construction of the French Past vol.1: Conflicts and Divisions (Chichester, 1996) pp.467-96
} 
d'étonnement, lorsque vous verrez quelles différences de population, de richesse territoriale, manufacturière et commerciale, présentent les deux grandes divisions de la France, que nos ancêtres distinguaient en pays de la langue d'oïl et pays de la langue d'oc'. ${ }^{350}$ Dupin's solution was popular education and linguistic centralization:

C'est donc l'instruction populaire, celle du paysan, de l'ouvrier, qui doit nous occuper avant tout. Le premier élément d'un succès très-étendu serait, à coup sûr, l'uniformité du langage, uniformité qui rend à la communication des idées et des lumières, les mêmes services que l'uniformité des poids et des mesures rend au commerce, à l'échange de tous les objets matériels et palpables. ${ }^{351}$

Dupin formulated linguistic difference both as a feature of the popular classes, and as an object of social reform. It was the peasant, the worker who did not speak French, and this linguistic diversity presented an obstacle to national integration and economic progress. This understanding of language as a social issue was coupled with a geographical sensibility. Like Maggiolo, Dupin set out to map backwardness, and found it correlated with linguistic difference. Dupin thus formulated the language question in terms reminiscent of the Abbé Grégoire and the Departmental statistics, as a social issue that properly should be considered an object of state intervention of a type the Coqueberts, focused on the entrenched nature of linguistic diversity, considered ultimately ineffective.

${ }^{350}$ C. Dupin, Forces productives et commerciales de la France vol.1 (Paris, 1827) p.v

351 lbid., p.48 


\section{3. 'Le Nom Ignoble de Patois'- Cultivated Language and the Speech of the People}

Those who provided information and translations to the Coqueberts seldom identified with the kinds of ethnic linguistic groupings the Coqueberts sought to uncover. For them, linguistic diversity was more frequently understood in terms of status- of the languages themselves and those who spoke them. This attitude was expressed in 1805, a year before the Coqueberts began their enquiry, when Théodore Poitevin presented a series of reflections on the history and etymology of Languedocien to the Société libre des science et belles-lettres de Montpelier. Poitevin opened his disquisition with a somewhat rueful lament for the fallen status of the language of Montpellier. As he wrote,

La fortune des langues ne dépend bien souvent que des événements politiques. Personne n'ignore combien le sort du françois et du languedocien sont différents. Le françois parlé par une cour élégante et polie, enrichi par les plus grands écrivains, est devenu la première langue de l'Europe; tandis que le languedocien n'est guères [sic.] connu que sous le nom ignoble de Patois. ${ }^{352}$

Patois, the ignoble word denounced by Poitevin, is a term that can evoke the broad sweep of the history of France's regional languages. The word was, and remains, pejorative. It revealed the gulf in status between French, the language of the Parisian court, and the regional languages of France. French was, in Poitevin's words, the first language of Europe. It occupied this position because it had been enriched by eminent writers and above all used by elites. The success of French could have fallen to Languedocien, had only the capital of the kingdom been situated south of the Loire, for Languedocien was equally 'cultivated', in Poitevin's terms, by medieval poets such as the troubadours, and in this alternate history it was the language of Paris, rather than the language of Montpellier, that would have been denigrated as a 'jargon rustique et grossier'. ${ }^{353}$ The superiority of French, therefore, rested on the coincidence of two factors - its function as a medium of political power and social distinction, and its cultivation as a language of literature. French was, in short, the

\footnotetext{
${ }^{352}$ T. Poitevin, 'Réflexions sur quelques étymologies languedociennes qui dérivent directement du Grec', Recueil des bulletins de la société libre des sciences et belles-lettres de Montpellier vol.2 no.16 (1805) pp.37-8 ${ }^{353}$ Poitevin, 'Réflexions' p.38
} 
language of literate high culture, while regional languages were more often than not considered no more than local speech.

Even before the Revolution, it would be misleading to suggest that the linguistic diversity of the French population could be reduced to this opposition between high status, literate French used by the elites and the speech of the people. The German speakers of Alsace, for example, guarded jealously the status of their tongue, and the linguistic policies of the Revolution drove many prominent intellectuals in Strasbourg to a full throated defence of German as a medium of written and political communication. ${ }^{354}$ The expansion of the borders of the French state during the Revolutionary and Napoleonic period brought with it a much larger population accustomed to using a language other than French as a medium of literate exchange. When Aubin-Louis Millin, who travelled across northern Italy in 1811, arrived in Menton, today the last French town before the Italian border, he claimed it was obvious that he was entering a foreign country, for while the population understood French, 'toutes les affiches sont en italien; toutes les annonces se font dans la même langue'. ${ }^{355}$ Yet even with the incorporation of this region into the French state, with the ensuing competition between French and Italian over dominance of public and written communication, this was not the sole distinction. Italy, like France, has its dialects and regional languages. As the Subprefect of Suze in the neighbouring department of Montenotte wrote, 'le langage dans lequel on s'exprime en piémont n'ayant point de patois et pouvant être considéré luimême comme tel'. ${ }^{356}$

These commentaries return us to two central concepts that have animated sociolinguistic work on linguistic minorities for some time- diglossia and standardization. We are, it would appear, describing contexts whereby different languages fulfilled different communicative functions- with standardized languages, those with a well-established literary tradition, used, broadly speaking, for

\footnotetext{
${ }^{354}$ D. Bell, 'Nation-Building and Cultural Particularism in Eighteenth Century France : The Case of Alsace', Eighteenth Century Studies vol.21 no.4 (1988) pp.472-490

${ }^{355}$ A.-L Millin, Voyage en Savoie, en Piémont, à Nice, à Gênes (2 vols., Paris, 1816) ii, p.144

${ }^{356}$ BnF Naf 5912 Sous-préfet de Suze au Ministre de l'Intérieur, f.20
} 
formal, written communication, while the dialects were predominantly, although not exclusively, used in spoken communication. Calqued on top of these functional distinctions was the further assumption that social class structured the linguistic capacity of speakers. Dialect, or 'patois', was thought to be predominantly the language of 'the people'- a feature of popular culture, while the more prestigious 'grammatical' languages required education to master- they were fixed by grammars and dictionaries and could be spoken 'correctly'. This chapter will argue that the movement from the ideological prescriptivism expressed by partisans of cultivated languages to the distinction between linguistic varieties on the basis of the social background of their speakers came to be one of the central features of linguistic culture during the period. This was in large part a result of Revolutionary concerns for the language of the people, which manifested themselves in the work of the Abbé Grégoire and later made themselves felt in the Departmental Statistics. As scholars such as Patrice Higonnet and Pierre Bourdieu have argued, such efforts to educate the population can also be used by social elites to buttress privilege, as they lionize the authorized forms that are to be aspired to but which are difficult to achieve without the benefits and resources of education and cultural capital. ${ }^{357}$ Nowhere was the pervasive nature of such attitudes clearer than in the correspondence gathered by the Coqueberts.

\section{Patois et Dialectes Vulgaires- Linguistic Difference and Popular Culture}

In France, concern about popular speech was inextricably bound up with the notion of that 'ignoble' term decried by Poitevin- Patois. In the seventeenth century the term patois, which had originally meant 'incomprehensible speech' came also to refer to the 'coarse and rustic speech of the common people. ${ }^{358}$ The complex meanings and connotations of the term were even clearer in the anonymous and frequently cited entry in the Éncyclopédie;

Patois- (Gramm.) langage corrompu tel qu'il se parle presque dans toutes les provinces : chacune a son patois ; ainsi nous avons le patois bourguignon, le patois normand, le patois

\footnotetext{
357 P. Higonnet, 'Linguistic Terrorism'

358 P. Bourdieu, Language and Symbolic Power p.47
} 
champenois, le patois gascon, le patois provençal, \&c. On ne parle la langue que dans la capitale. $^{359}$

This definition seems to rest on at least three distinctions. It begins with a normative description'corrupted speech' (the use of the French 'langage' here is instructive), presumably to be contrasted with 'pure' language. The author of the definition seems to have been making the claim that a patois with its 'corrupted' nature somehow violated the standards of a proper language. The definition thus makes reference to the notion of a 'standard' language, with norms fixed by dictionaries, grammars and a canon of literary works. ${ }^{360}$ However, the definition also contains a geographic dimension; since patois was spoken in the provinces we are told that there exists 'le patois bourguignon, le patois normand, le patois champenois, le patois gascon, le patois provençal, \& $\& c^{\prime}{ }^{361}$ The definition thus roots each patois in a particular region of France, which can then be characterized by its linguistic particularism. This division of France makes reference to older political entities- the duchies of Burgundy, Normandy and Provence, showing once again how political boundaries can impinge upon the linguistic consciousness of individuals. Indeed, the entry associates the centre of political power with correct language, claiming that 'on ne parle la langue que dans la capitale. $^{362}$

The study of France's regional languages, and the ample use of the term patois in its pursuit, has been seen to marginalize France's regional and minority languages, casting them as popular phenomena. From the middle ages, local dialect and languages were associated with popular speech in the form of the proverbs and stories collected by lawyers, ecclesiastics and members of the literate classes in search of sources of eloquence. ${ }^{363}$ The sayings of the people might, it was felt,

\footnotetext{
359 'Patois', D. Diderot and J. le Rond D'Alembert (eds.) Encyclopédie, ou dictionnaire raisonné des sciences, des arts et des métiers, V.12 p.174 University of Chicago: ARTFL Encyclopédie Project (Spring 2011 Edition) http://artflx.uchicago.edu/cgi-bin/philologic/getobject.pl?c.11:252.encyclopedie0311 accessed 19/02/2012 ${ }^{360}$ Haugen, 'Dialect, Language, Nation' pp. 922-35. For a discussion of the concept of standardization in the context of France see Lodge Dialect to Standard ch. 1. 361 'Patois', Encyclopédie.

362 Ibid.

${ }^{363}$ N.Z. Davis, Society and Popular Culture in Early Modern France (Stanford, 1975) ch. 8.
} 
provide a useful way of expressing thoughts in the courtroom or from the pulpit so that they might be more easily understood by the audience. Yet in the latter part of the eighteenth century, the learned and lettered began to take an interest in the language and culture of 'the people' not as a sin to be pardoned, a malediction to be cured or an inspiration for poetic expression, but as an object to be studied ${ }^{364}$ Across much of Europe interest in popular culture and indeed language flourished from the late 1770 s onwards into what has been termed a 'rediscovery of the people,' notably with the publication of Herder's collection of Volkslieder or folk songs in $1778 .{ }^{365}$ Interest in language was often associated with the proto-nationalist movements that would eventually emerge to challenge the European order set out in the Congress of Vienna in 1815, and language came to be seen as a crucial element in establishing the legitimacy or otherwise of European polities. ${ }^{366}$

This interest in popular culture was often accompanied by a desire to reform social practice. Describing was the prelude to prescription, a transition most evident in France. While the country was populated by a number of linguistically, perhaps even culturally distinct groups, such divisions were overlain by a dominant learned culture and increasingly centralized state, both of which had long utilised French. This language dominated in written and learned spheres while regional languages occupied a largely marginal position. This was particularly the case with studies such as that of the Abbé Grégoire during the Revolution. A central concern for Grégoire was not just a familiarity with the national language, but a mastery of it, an ability to speak and write it correctly. ${ }^{367}$ Projects like that of Grégoire rested on two precepts. Firstly, a learned linguistic culture characterised by a rigid prescriptivism that demanded 'proper usage' as defined by dictionaries and grammars. Secondly, it presumed a conflation of linguistic diversity and 'popular' culture. The result

\footnotetext{
${ }^{364} \mathrm{~J}$. Revel, 'Forms of Expertise: Intellectuals and Popular Culture in France, 1650-1800' in S. Kaplan (ed.) Understanding Popular Culture: Europe from the Middle Ages to the Nineteenth Century (New York, 1984) pp. 269-272. 365 P. Burke, Popular Culture in Early Modern Europe (London, 1978) ch. 1.

${ }^{366}$ R.J.W. Evans, 'Language and State Building, the Case of the Habsburg Monarchy' in Austrian History Yearbook vol. xxxv 2004 p.2

${ }^{367}$ See above, ch.1
} 
was a tendency to describe the linguistic production of regional language speakers as 'improper' or 'corrupt', the result of a lack of the education enjoyed by the literate and French-speaking.

The Coqueberts similarly understood language as a characteristic of the people. In the initial stages of their enquiry they had sought to distinguish between the territories of French and other prominent European languages of literate culture such as Italian and German, but their distinction was linguistic and geographic. Far less prestigious languages such as Breton and Basque were arranged alongside French and German by the Coqueberts not because they rivalled French as vehicles of written or learned communication, but because they were linguistically distinct and were thought to reflect cleavages in the social and cultural characteristics of the population. The social basis of the Coqueberts' vision of linguistic difference became explicit as they passed from the study of the 'langues mères' to the 'dialects et patois,' articulating a view of linguistic difference as a marker of social stratification. In September 1807 the aims of the enquiry were expressed to the prefect of the Ain in the following terms; 'je suis dans l'intention de connaitre avec quelque détail les divers idiomes qui sont d'un usage vulgaire dans l'étendue de l'empire'. ${ }^{368}$ As with Oberlin in the 1770s and Grégoire during the Revolution, the Coqueberts were interested in the speech of the people.

It was the concept of popular speech that made the collection of linguistic samples possible for the local notables who translated the parable of the prodigal child into their local dialects for the Coqueberts. Throughout the enquiry the Coqueberts insisted that those charged with translating the parable pay close attention to the language as it was used by 'the people,' and the desire they expressed to the prefect of the Ain to examine the 'patois ou dialects qui sont d'un usage vulgaire' became a frequent refrain in their requests to the provinces. This desire was evident in the frustration of late 1807 that, upon examination of a version of the parable transmitted to him from the northernmost tip of the Rhineland, led the elder Coquebert to complain in a note attached to

${ }^{368}$ BNF NAF 5910 Coquebert de Montbret au Préfet de l'Ain, 30th sep. 1807 f.18 
the parable, 'cette traduction est en très bon allemand et ce n'est surement pas ainsi qu'on le parle à Wegberg. Elle ne peut servir de rien. ${ }^{\prime 36}$ The German used in the translation was simply 'too pure' to be authentic. The sample from Wegberg should have been, by implication, somehow 'less pure.' For his part, the mayor of Wegberg grasped exactly what Coquebert meant by 'pure German'. This much is evident in his response to Coquebert's dissatisfaction with his translation, which had been passed to him through the sub-prefect of his arrondissement:

Le ministre de l'intérieur vous [M. le sous-préfet] observe [...] que la traduction de la parabole de l'enfant prodigue que je vous ai envoyée soit infiniment plus pure que celui que les habitans [sic.] de ma commune parlent habituellement. [...] Je vous assure, Monsieur le sous préfet, que dans toute l'étendue de ma commune les maitres d'école n'apprennent pas à leurs élèves que la langue Allemand ni les prêtres ne prêchent pas dans une autre langue, [...] les habitants ne savent pas écrire ni lire que cette langue. ${ }^{370}$

One might imagine that the mayor had no particular desire to furnish Paris with a second version of the parable, yet the manner in which he justifies his position- that he need not undertake another translation because the language the inhabitants of his commune spoke was, in fact, 'pure' Germanreveals some of the assumptions underpinning the use of this term. To speak 'pure' German one must be educated, thus the mayor insists on the good works of the commune's school teachers, and the positive influence of the priests. Furthermore, 'pure' German is related to the literate use of language, thus the mayor emphasises that the inhabitants of Wegberg read and wrote (only) in German.

Coquebert's objection to this translation, along with the mayors' defence of it, reveal why the concept of a patois, of a distinction couched in social terms between the speech of the educated and that which was 'd'un usage vulgaire' was so important to the functioning of the enquiry. In a context in which the 'language' used by the educated was so closely tied to the notion of 'purity' laid down for the literate in dictionaries and grammars, regional variations in language- that is to say, dialect- were not only considered different, but incorrect. To map the geography of dialects across

\footnotetext{
${ }^{369}$ BnF Naf 5911 f.328.

${ }^{370}$ BnF Naf 5911 Maire de Wegberg au sous-préfet de Ruremonde, 26 Jan. 1808 f.321
} 
the Empire therefore required the collection of language that deviated from the 'standard', and this meant 'popular' speech.

The notes and explanations accompanying the materials received by the Coqueberts, particularly the translations of the Parable show how the concept of 'popular speech' or 'language' allowed the recording of dialect as it was spoken. The sub-prefect of Montfort in the department of the lle et Villaine explained to Coquebert that in translating the parable he had 'rendue autant qu'on l'a pu en expressions familières aux gens de la campagne; on a essayé de rendre aussi quelques vues au prononciation. ${ }^{371}$ In order to do this, the respondents were frequently required to develop their own orthography to represent the features of the local language. As the prefect of the department du Gers explained, 'trop peu d'auteurs ont écrit, ou publié leurs ouvrages en patois, pour que l'orthographe du dialecte gascon, [...] soit bien fixée. ${ }^{\prime 372}$ The prefect went on to cite the work of two seventeenth century Gascon poets, J.-G. D’Astros and Pierre Goudelin in establishing his orthography:

Dastros a toujours, autant qu'il l'a pu, ecrit au pour aou. L'on avertit donc ici, que toutes les syllabes au doivent toujours etre prononcés aou ; pronontiation, au reste, assés difficile pour celui qui n'a pas l'usage de ce patois, parceque l'o, qui constitue la différence, y doit être presque insensible : il en est de même pour cette lettre $O$, dans les mots où se trouvent les syllabes eou que Goudelin ecrit eu, quoique la pronontiation soit la même dans la Haute Garonne que dans le Gers. ${ }^{373}$

The response makes evident, therefore, the concern with how, in the absence of a system of phonetic transcription, to represent the local pronunciation in text. The solution adopted, was to adapt French orthography to best represent the sounds of the local language. As the prefect observed, 'au reste, on doit prononcer les e et les $\underline{i}$, toujours avec leur propre son, au lieu de le leurs faire perdre, pour se trouver suivis d'une consonne, comme dans la langue françaïse. ${ }^{\prime 374}$ Thus the

\footnotetext{
${ }^{371}$ BnF Naf 5911 Sous-préfet de Montfort au ministre de l'intérieur, 13 Sept. 1809 f.175

372 BnF Naf 5911 Préfet du département du Gers au ministre de l'intérieur, 10 Feb. 1810 f.46

373 BnF Naf 5911 Vocabulaire contenant l'explication des mots du patois Gascon dans ce patois, envoyé par le préfet du Gers au ministre de l'Intérieur f.47

${ }^{374}$ BnF Naf 5911 Vocabulaire contenant l'explication des mots du patois Gascon dans ce patois, envoyé par le préfet du Gers au ministre de l'Intérieur f.48
} 
orthographic rules of French were followed in representing the local language, except where otherwise stated.

Those charged with providing translations of the parable to the enquiry generally followed the same pattern as the prefect of the department of the Gers in seeking to represent 'popular' language. Rather than following the orthography laid down by those who wrote in the language, they tended to adapt orthographic rules techniques from two sources, French and Latin, to represent 'popular' pronunciation on the page. Thus a respondent from Gap, a member the Société d'émulation of the department of the Hautes Alpes discussed the difficulty of representing the word 'mais'; 'ce mot et tous ses analogues par la terminaison est d'une prononciation d'autant plus difficile, que le français ni le latin ne fournissaient aucun exemple à mettre sous les yeux du lecteur pour lui en donner une idée, le son qu'il produit semble se rapproches de celui du mot français Maïs'. ${ }^{375}$ The solution, using the accented ' $i$ ' to represent an elongated vowel sound, has a certain logic, as seen in the recourse to the archaic orthography of 'païs' in place of 'pays' in the letters accompanying some responses. ${ }^{376} \mathrm{~A}$ similar use of accents as part of the adaptation of French orthographic rules to represent local pronunciation is evident in the response of the prefect of the Haute-Saone in his discussion of the Franc-Comtois, a Langue d'oil dialect in use in his Department: 'Le comtois a l'accent lourd, trainant et vicieux, surtout dans les sillabes où domine le son oi qu'il prononce oè, telles que Roè pour Roi, toè pour toi ${ }^{.377}$ Meanwhile, in a move that seems to underscore Renée Balibar's thesis that Latin remained crucial to the way in which the educated studied and used language during the period, ${ }^{378}$ the mayor of Monségur in the department of the Gironde, stated that 'd'après les conseils de $M$. le sous-préfet de la Réole, [j'ai] emprunté les signes qu'on employe pour la poësie latine à fin de marquer les longues et les brêves qui termine le

\footnotetext{
${ }^{375}$ BnF Naf 5910 Fernaud, membre de la société d'émulation des Hautes Alpes au ministre de l'intérieur f.72

${ }^{376}$ BnF Naf 5910 Juge de paix du Canton du Montbron, département de la Charente, au ministre de l'intérieur, 14 May 1810 f.220

377 BnF Naf 5912 Préfet de la Haute-Saone au ministre de l'intérieur, 29 Sept. 1812 f.166

${ }^{378}$ R. Balibar, L'institution du français; essai sur le colinguisme des Carolingiens à la République (Paris, 1985) p.158
} 
mot. ${ }^{379}$ The translation of the parable he attached was complete with the prosody markings familiar to classicists, markings that were retained by Coquebert when he transcribed the version. ${ }^{380}$

When it came to the vocabulary used to complete the translations the notion of 'popular' usage was also important as a criterion allowing the representation of speech as it was in use in the area. Thus the Genoese translator of the parable observed in a note on his version:

Le mot ezzenda qui répond exactement au Bíos ou Oúoía du texte Grecque \& à subtantia de la vulgate, n'est encore, en parlant strictement, qu'un néologisme dans le dialect génois, ayant été tiré du mot agrienda de la langue italienne. Mais l'usage en est si générale que j'ai cru pouvoir m'en servir impurement pour traduire à la lettre un terme, que je n'aurais pu rendre autrement que par une circonlocution vicieuse. ${ }^{381}$

In taking such a position the Genoese translator was clearly in opposition to the views of François Raymond Martin, the son of a merchant from Montpellier. Martin criticised the notion that the translation of the parable should represent the language of 'the people':

Ce n'est pas que l'on pût approuver un auteur qui, d'après l'opinion reçue que l'ancien patois s'est conservé chez le bas peuple, n'emploîrait [sic] que les locutions de nos halles, pour traduire la parabole de l'enfant prodigue, et ne ferait alors qu'une copie dégoûtante et grotesque d'un original majestueux et important. ${ }^{382}$

Significantly, Martin followed up his initial letter to Coquebert with an essay entitled Précis historique du dialecte de Montpellier which stretched to 16 pages plus appendices and began its account of the genesis of Provençal in the classical period, ${ }^{383}$ as well as an anthology of poetry and songs in the 'Patois de Montpellier.'384 Martin pointedly gives us a historical account of the 'dialecte de Montpellier', recounting its greatest poets, lamenting wistfully its lost status and reminding us of its majesty as a written form.

\footnotetext{
379 BnF Naf 5911 Maire de Monségur au ministre de l'intérieur f.84

${ }^{380}$ BmR Ms Mbt 489 Arrondissement de la Réole, traduction de la parabole de l'enfant prodigue. The first line of the text thus reads as follows : 'ŭn home ăvăit deu gōuȳa dŏn lĕ pŭ jeunē dīssīt ă son̆ pĕre: mŏn pĕrĕ baillēz meū cē quĕ jĕ dioùi augere dĕ voutrĕ bien.'

${ }^{381} \mathrm{BnF}$ Naf 5911 la parabola dro figgio proddigo, département des Gênes f.25

382 BnF Naf 5911 Martin au ministre de l'intérieur 4 May 1812 f.128

${ }^{383}$ BnF Naf 5911Précis historique du dialecte de Montpellier, Martin au Ministre de l'intérieur 28 août 1812

ff.139-62

${ }^{384}$ BnF Naf 5914 (Patois de la France V- Patois du Montpellier)
} 
In making a case for the credentials of the 'dialecte de Montpellier' as a language fixed by a literary tradition, Martin once again underscores the importance of the idea of 'popular speech' when it came to the collection of linguistic samples. Martin decried the use of the expressions of the 'bas peuple' in the translation of the parable, arguing for the literate dignity of the language to be maintained. However, doing so would have obscured the language in use in the various parts of France in favour of the forms that the literate enthusiast for the local dialect thought should be used. This was exactly the point made by the sub-prefect of Villefranche in the department of Aveyron, who criticised the use of poets such as Beyrol and Goudilin to represent the patois of his arrondissement. As he claimed, 'les poésies de Beyrol, prieur de Beachinas, ne sont pas du tout dans le dialecte villefranchois. Goudouli [sic.] a écrit en véritable patois Toulousain.' Unlike the stereotype of an isolated and illiterate rural dweller who could provide the ideal 'authentic' sample of the local language, both these poets had spoken and written French. Consequently, both authors 'ont mis la plupart des termes français en patois' and as a result, 'leurs ouvrages quoique bienfait en soi, donneraient une fausse idée du langage vulgaire du midi de la France. ${ }^{\prime 385}$ The sub-prefect of Villefranche thus echoed Coquebert's dissatisfaction with the translation provided by the maire of Wegberg. Where Martin sought to elaborate a literary standard from the works of the languages' writers, the enquiry turned precisely on the opposite, on collecting the various 'langages vulgaires' in use across the territory of France.

\section{Languages in Contact and Conflict}

As the replies from Wegberg and from Northern Italy demonstrate, the issue of patois was not confined to those parts of the Empire that had formerly been part of France. In nominally Italian and German speaking regions, the quotidian speech of the population did not conform to elite notions of grammatical correctness or purity any more than it did in patois-speaking France. As a result, it seems sensible to talk of two distinct types of linguistic contact, even conflict, during the

${ }^{385}$ BnF Naf 5910 Sous-préfet de l'arrondissement de Villefranche, au préfet du département d'Aveyron 24 Aug. 1808 f.142 
period, distinguished by their sociolinguistic character- that is, according to 'who spoke what to whom and when', to adapt Joshua Fishman's formulation to the study of past societies. ${ }^{386}$ On the one hand, speakers of standardized languages such as French, German and Dutch, that had for centuries competed for 'territory', in the words of Peter Burke, not just over physical space but over the contexts in which they should be used, existed in large numbers within the borders of the empire. ${ }^{387}$ On the other hand, each of these languages formed only part of the communicative repertoire of these linguistic communities who spoke them- they all existed alongside dialects or regional languages which themselves were used by different speakers in different contexts.

As the mobilization of popular culture in the study of dialect by the Coqueberts makes clear, elites exploited their command of standardized, prestige languages to distinguish themselves from the mass of the population. The selection of varieties came down not only to the social position of the speaker but to the communicative context. Social elites themselves often employed local dialect in informal contexts. In the Rhin-et-Moselle, for example, the German dialects in use were also 'très fréquemment l'idiôme ordinaire de personnes lettrés, ou ayant joui d'une bonne éducation ; ce qui n'a cependant lieu que dans leur réunions ou occupations particulières' ${ }^{388}$ Conversely, the response from the canton of Seyne in the Basses-Alpes made clear not only that the local dialect was not habitually used in written culture, but that French here was significant and understood in formal situations: 'Jusqu'ici il n'a peut-être jamais été rien écrit selon le dialecte de ce canton. Toutes les instructions publique s'y sont toujours faites en français que tous comprennent'. ${ }^{389}$

The salience of distinguishing between varieties on the basis of the communicative function to which they were put, rather than simply as a feature of social stratification, becomes clearest where prestige varieties came into contact. To take the example of the arrondissement of Suze, in

\footnotetext{
${ }^{386} \mathrm{~J}$. A. Fishman, 'The Relationship between Micro- and Macro-Sociolinguistics in the Study of Who Speaks What Language to Whom and When', J.B. Pride and J. Holmes (eds.), Sociolinguistics (Harmondsworth, 1972) p.15

${ }^{387}$ P. Burke Towards a Social History of Early Modern Dutch (Amsterdam, 2005) p.14

${ }^{388}$ BnF Naf 5912 Préfet du Rhin et Moselle au Ministre de l'intérieur, 6 Dec. 1808 f.111

${ }^{389}$ BnF Naf 5910 Canton de Seyne f.54
} 
the west of the Piedmontese department of the Pô, Italian, French, Piedmontese and patois all existed with speakers in different areas making different choices about which language to employ in given situations. According to the sub-prefect, the basic division was between French and Piedmontese, a language that lacked the prestige and recognition of Italian, but which was currently the object of something of a revivalist movement centred on Turin. ${ }^{390}$ French dominated in three of the eight cantons in the west of the arrondissement- Oulx, Cezanne and Bardonêche with Piedmontese the principal language in Giaveno and Avigliana. Bussolino and Villar-Amase both had their own 'particular' idioms, of which the former was considered less 'grosier et barbare' than the latter, although as the sub-prefect observed, 'Les habitans de toutes les communes de ces derniers cantons parlent également le piémontais, mais ils n'en font usage que lorsqu'ils sortent de leur territoire, ou qu'ils cherchent à se mettre en communication avec les étrangers' ${ }^{391}$ The final canton, that of Suze itself, was linguistically mixed. According to the sub-prefect, the population of the eastern communes of the canton expressed itself 'en assez bon français', yet as one moved westward the situation quickly changed, until one reached the commune of Greniers, a village of 'pauvres cultivateurs [où] on n'y parle que le patois' ${ }^{392}$

Already the comments of the sub-prefect reveal a complex threefold distinction of linguistic variety. The territory straddled a divide between Piedmontese and French, with various dialects socially marked as the language of impoverished farmers, and used to mark the limits of a perceived linguistic community through the use of dialect to communicate with insiders and Piedmontese with outsiders. Piedmontese was also the language of religious preaching, and dominated the markets of the arrondissement's chef-lieu. The communities of the east of the department struggled to impose French as their preferred prestige variety over both Piedmontese and Italian in certain communicative settings. As the sub-prefect observed of these communities,

\footnotetext{
${ }^{390} \mathrm{~K}$. Bochmann, 'La France napoléonienne et ses langues', in G. Kremnitz (ed.) Histoire sociale des langues de France (Rennes, 2013) p.284

${ }^{391}$ BnF Naf 5912 Rapport sur les différents dialectes usités dans l'arrondissement de Suze, département de Pô, f.18 392 Ibid., f.18
} 
C'est en français que les personnes des deux sexes apprennent à lire, et quoiqu'elles ne parlent entr'elles que le patois elles ont un gout de préférence pour le français qui leur fait amèrement regretter d'entendre leurs curés les prêcher en piémontais et leur enseigner le catéchisme en italien. ${ }^{393}$

It appears the distinction between the communes of east and west lay not principally in the use of dialect, but in a commitment to employ French as a prestige variety in place of both Piedmontese and Italian in the communicative contexts- in the school, the church and the catechism- where these other languages might be employed. French was the prestige language within these communities, and their members jealously guarded its use in education even if the members of the clergy did not oblige them. French was learnt in the commune, Piedmontese only through the exigencies of communication and trade with the rest of the arrondissement. As the sub-prefect wrote of one of the villages neighbouring Suze itself, 'les jeunes gens de cette commune comprennent le français avant de sortir de chez eux tandis que ce n'est qu'après avoir fréquenté les marchés de Suze qu'ils se familiarisent avec le piémontais'. ${ }^{394}$

Underscoring the differing functions for which languages such as French and local dialects were used, many of the Coqueberts' informants offered dialect songs and carols as examples of popular speech. These songs, often cited by informants as the only cultural artefacts in dialect they could provide, illustrated the different roles to which language and local dialect were put. As the prefect of the Corsican department of Golo warned the Coqueberts, 'vous ne devez pas vous attendre, monseigneur, de recevoir des ouvrages imprimés en langue vulgaire de l'lle, il n'en a jamais existé : on ne pourra transmettre à votre excellence, que des copies de chansons populaires'. ${ }^{395}$ The association of popular culture forms with dialect speech was evident in the large number of such songs sent to the Coqueberts. From the Saône et Loire, the Coqueberts received a

\footnotetext{
${ }^{393}$ BnF Naf 5912 Rapport sur les différents dialectes usités dans l'arrondissement de Suze, département de Pô, f.18-19

${ }^{394}$ BnF Naf 5912 Rapport sur les différents dialectes usités dans l'arrondissement de Suze, département de Pô, f.19

${ }^{395}$ BnF Naf 5911 Préfet du Golo to Ministre de l'intérieure
} 
canticle and a 'chanson rustique à la Charolaise', as illustrative of local speech ${ }^{396}$. The secrétaire général of the prefecture of the Lozère provided dialect lyrics, translations and a musical score for a number of songs in the patois of the department's inhabitants. ${ }^{397}$ From the Deux-Sèvres, the Coqueberts collected a working song for a plough team and a satirical song about a man attempting to surreptitiously look up a woman's dress, sung in the dialect of Poitou. ${ }^{398}$ The implication was that high culture- the sphere of written production- was dominated by languages such as French, while dialect was confined to popular oral culture.

While those responding to the Coqueberts persistently looked to popular singing culture as a source of patois texts, the majority of folk songs and stories collected during the nineteenth century were sung or told in French, or at least the closest approximation of the language those doing the singing or telling could manage. ${ }^{399}$ Those who performed them recognized French as the prestige variety, and thus chose to perform in the language in deference to the artistic character of the activity. In 1862, Damase Arbaud, charged with the collection of folk song in Provence by the Ministry of the Interior, observed precisely this practice of local performers singing, as far as possible, in French; 'dans les habitudes de la vie, on parlait le langage des aïeux; dans les occasions solennelles on jargonnaît la langue conquérante' ${ }^{400}$ For educated individuals like Arbaud, the French of these occasions may not have attracted derision as incorrect jargon, yet the construction of French as the prestige form was evident, and was also reflected in the folk songs themselves. In Christmas carols, Arbaud pointed out, the shepherds would frequently sing in dialect, and the angels in French, emphasising the relative status of the two languages. ${ }^{401}$

\footnotetext{
${ }^{396}$ An F17 1209 Saône et Loire- Chanson rustique à la Charollais

${ }^{397}$ BnF Naf 5911 Romance patoise, traduite par M. Broussons, secrétaire générale de la Lozère ff.276-82

${ }^{398}$ BmR Ms Mbt 191 Département des Deux-Sèvres ff.22-4

${ }^{399}$ A. de Félice, Contes de Haute-Bretagne (Paris, 1954) p.xii ; See also David Hopkin's work on the predominantly French songs of lacemakers in the Occitan speaking Velay, collected by Victor Smith in the 1860s and 1870s: Hopkin, Voices of the People p.230

400 D. Arbaud, Chants populaires de la Provence (Aix, 1862) p.xviii

${ }^{401}$ Arbaud, Chants populaires p.xix
} 
Arbaud was writing half a century after the Coqueberts, and the slow progress of literacy and knowledge of the French language revealed by those statistics we do possess must temper our application of his observations to the Napoleonic period. However, even if the proportion of French speakers changed the same singing practices were observed under the first empire, implying a degree of continuity in the linguistic attitudes and strategies underlying oral culture code-switching. Richard, the archivist from the department of the Vosges, transmitted a similar carol, wherein shepherds conversed in the patois of Neufchateau with the French speaking kings who were also paying tribute to the new-born Jesus. ${ }^{402}$ This kind of dialogue was not confined to carols. According to Lafont du Cujulà, who wrote to the Coqueberts on the language of the Lot-et-Garonne, 'on connait à Agen une chanson formant un dialogue vifs et assez spirituel entre un petit maître de la ville et une jeune villageoise. Il soupire en français et on l'éconduit en Gascon' ${ }^{403}$ Cujulà was certainly referring to the most prominent dialect-French dialogue songs in the repertoire of French folk music- the pastoral dialogues between a shepherdess and the travelling gentleman who tries to woo her. Patrice Coirault, whose work forms the basis of the French folk song catalogue, devoted an entire section to these dialogues, with 20 distinct song types, of which multiple versions were collected by folklorists from various parts of France. ${ }^{404}$ These songs did not reflect an uncritical deference to the French speaking world. In the great majority of these versions the Francophone suitor plays the role of the frustrated target of the song's satire. In a version of one of the most popular songs of this kind, Le monsieur renvoyé, collected by Vicent d'Indy in the south-eastern department of the Ardèche, an area Indy referred to by its archaic regional toponym as the Vivarais, the Monsieur chides his reluctant love interest for showing him less affection than her dog. The shepherdess responds that the dog is interested only in the food he is carrying:

Le Monsieur :

\footnotetext{
${ }^{402}$ An F 17 1209Richard, Patois des Vosges, Idiome de l'arrondissement de Neufchâteau

${ }^{403}$ BnF Naf 5911 Lafont du Cujulà, Notice sur le langage et les usages particuliers des habitans du département de Lot et Garonne f.268

${ }^{404}$ P. Coirault, G. Dulaure, Y. Fédoroff, S. Wallon, Répertoire des chansons de tradition orale vol. 2 La vie sociale et militaire (Paris, 1996) pp.74-82
} 
Ton chien, ma bergère,

Est plus humain que toi,

Me sent, me caresse,

Vient auprès de moi.

La Bergère :

Oh! La fin bestia (Oh! La fine bête)

Qué sen lous croustous! (Qui sent les croutons)

Ma figuo, sé sarra (Ma foi, s'il se presse)

Se mouqua de vous! (c'est qu'il se moque de vous) $)^{405}$

In another version of the same song, collected in the 1890s in Franche Comté by Charles Beauquier, the Monsieur complains to 'Slyvie' that his unrequited love for her is causing him great suffering. Sylvie responds by directing him to the apothecary. ${ }^{406}$

In these songs the use of both French and dialect function as a mechanism to define the social background of the characters, heightening the satire of the courtship and rejection. The songs thus reveal both the capacity of French to confer social status on a speaker in the same way as the different forms of address- the Monsieur uses 'vous', the shepherdess 'tu'- as well as the practice of code-switching within popular culture forms. Code-switching, the phenomenon of speakers using more than one linguistic code in a single communicative act, is a frequently attested feature of multilingual situations, and the presence of code-switching in this kind of cultural production provides valuable insight into the subjective attitudes of speakers towards language, and the linguistic strategies they pursued. While code-switching has been studied from both psycholinguistic and structural perspectives- as cognitive process and as determined by the syntax of both languages- the most fruitful perspectives from a historical point of view are functionalist ones as a mechanism for the 'negotiation and definition of social roles, networks and boundaries' ${ }^{407}$ This does not mean a simple division into 'them' and 'we'- speakers select varieties depending on their own

\footnotetext{
${ }^{405} \mathrm{~V}$. d'Indy, Chansons populaires du Vivarais, recueillis et transcrites avec accompagnement de piano (Paris, 1892) p.34. The translations are those provided by Indy.

${ }^{406}$ C. Beauquier, Chansons populaires recueillies en Franche-comté (Paris, 1894) p.352

${ }^{407}$ M. Heller 'Introduction', in M. Heller (ed.), Codeswithching : Anthropological and Sociolinguistic Perspectives (Berlin, 1988) p.1
} 
repertoires and strategies, their own desire to identify with a given group. ${ }^{408}$ Minority languages do not automatically constitute markers of insider status- 'we' languages- for their speakers, who often make use of prestige forms to make claims to social status. ${ }^{409}$ The social context, therefore, was crucial, for the practice and frequency of code-switching is informed by the conditions of social interaction. In contexts where linguistic difference is understood as an element of ethnic conflict, for example in 1980s Catalonia, where political conflict surrounding state language policy was intense, bilingual speakers may choose to employ code-switching very rarely, because the value of identifying as an insider of a given group- in this case as a Catalan- trumps the prestige value of employing Castillian. ${ }^{410}$ In the case of the bilingual dialogues of folk singers, the selection of linguistic variety was clearly not ethnic, but social.

These instances of code-switching matter because they reveal the distribution of a particular feature of linguistic practice- the use of French as a prestige variety alongside regional languages. These songs were a common part of the repertoire of folk songs across large parts of France. They appear to have been sung by both men and women- in 1897 Slyvain Trébucq collected a version of a similar bilingual dialogue, Dis-moi, Nanon, le nom de ton village, in the Vendée from a 22-year-old teacher, essentially the same song Gustave Fraipont recalled hearing the daughter of the mayor of Savannes singing as she herded livestock to market while he was travelling in the Auvergne. ${ }^{411}$ Joseph Daymard claimed to have collected five or six versions of Le monsieur renvoyé in the southwestern region of Quercy, although he doubted the song was authentically popular in origin- he felt it lacked the 'simplicity' of songs composed by the 'people'- and printed only one. ${ }^{412}$ From the perspective of tracing the geography of bilingual practice the songs reveal, their origins are far less

\footnotetext{
${ }^{408}$ R.B. Le Page, D. Tabouret-Keller, Acts of Identity : Creole Based Approaches to Language and Ethnicity (Cambrdige, 1985) p.14

${ }^{409}$ M. Sebba, T. Wootton, 'We, They and Identity : Sequential versus identity-related explanation in codeswitching', P. Auer (ed.), Code-Switching in Conversation: Language, Interaction and Identity (London, 1998) pp.262-4

${ }^{410}$ K.A. Woolard, 'Codeswitching and Comedy in Catalonia', Heller (ed.), Codeswitching pp.55-6

${ }^{411}$ S. Trébucq, La chanson populaire et la vie rurale des Pyrénées à la Vendée vol.2 (Bordeaux, 1912) p.252 ; G. Fraipont, Les montagnes de France- L'Auvergne (Paris, 1902) p.313

412 J. Daymard, Vieux chants populaires recueillis en Quercy (Cahors, 1889) p.162
} 
significant than their presence in singers' repertoires. Not all of the versions collected of these Bergère-Monsieur dialogues employed code-switching to mark status. For example, three versions of Dis-Moi, Nanon were recorded entirely in French, in Lorraine the department of the Vienne and Québec. ${ }^{413}$ Three versions of the song were recorded entirely in patois, all in the Dordogne..$^{414}$ However, the vast majority of those collected did employ two languages. No fewer than 50 versions of various Bergère-Monsieur dialogues collected between 1842 and 1914 have the shepherdess speaking in patois and the Monsieur in French. The folklorists who published 49 of these versions noted the town or village where they were collected, and their locations are given in Figure 8. This map shows that the bilingual dialogues were popular in the Occitan speaking south of the country, yet they were also sung in French speaking Switzerland, in Franche-Comté and Lorraine in the northeast, and in Poitou in the west.

The distribution of code-switching in the Monsieur-Bergère dialogues collected throughout the nineteenth century closely resembles that of the translation of the parables collected by the Coqueberts under Napoleon. The maps seem to reveal a tripartite geography of linguistic diversity, between a solidly French speaking core, a large intermediate zone where dialect and French were used by different speakers for different communicative functions, and parts of the Empire where other standardized languages had long existed as the prestige variety, often alongside their dialects. The first category included the lle de France, the present day Centre, Normandy and upper Brittany. This second category comprised much of present day France, both in the Occitan speaking south and to the south-east and west of the Francophone core, French speaking Belgium, Switzerland and northern Italy. The final grouping is traced roughly by the Coqueberts' original 1806 maps showing the division between French and the other standardized languages- French, German and Dutchlanguages that themselves existed alongside regional forms.

\footnotetext{
${ }^{413}$ T.B. de Puymaigre, Chants populaires recueillis dans le pays messin (Metz, 1865) p.123 ; L. Pineau Le folklore de Poitou (Paris, 1892) p.243 ; E.-Z. Massicotte and C.M. Barbeau, 'Chants populaires du Canada', Journal of American Folklore vol.32 no.123 (1919) pp.48-50

${ }^{414}$ E. Casse Les vieilles chansons patoises du Périgord (Périgeux, 1903) pp.30-1
} 
The terms of trade, so to speak, between these languages were not everywhere the same, and could vary quite locally, something particularly evident within the area of the second category of French-dialect relationship. The entirely patois versions of the Monsieur-Bergère dialogues, which might be thought to reflect a more monolingual linguistic culture, were collected in proximity to bilingual versions. ${ }^{415}$ Contemporaries remarked that French was spoken with greater frequency close to important roads or towns, an observation supported by popular biography. ${ }^{416}$ When JacquesLouis Ménétra, a glazer from Paris who travelled across the country as a journeyman apprentice in the middle of the eighteenth century, mentioned language, it was not in terms of incomprehension, but of his manner of speaking marking him out as a Parisian. Ménétra recalled with no little pride that, while visiting an inn between Bordeaux and Toulouse, the innkeeper had recognised the purity of his French, and offered him free room and board in return for staying up all night to tell him tales about the capital. ${ }^{417}$

The differing degrees of penetration by French across some regions led to a differing allocation of communicative functions between the standardized national tongue and regional varieties. As the sub-prefect of Seyne in the Haute-Alpes observed, nothing was written in the local dialect, with French dominating not only literate activity but oral contexts such as the practice of religion. This contrasted markedly with the situation in Roussillon, where Michel Brunet has described the halting implantation of French and the resulting vigour of Catalan as the language of elite correspondence, religious proselytizing, politics and even very occasionally official communications. ${ }^{418}$ French dominated written culture in much of the south-east despite a short lived enthusiasm for printing political tracts in Occitan during the early years of the Revolution as a

\footnotetext{
415 Casse, Les vieilles chansons pp.30-1

${ }^{416}$ F. Lamarque, Statistique du département du Tarn (Paris, 1800) p.11 ; D.-J. Quenin Statistique du canton d'Orgon (Arles, 1838) p.87

417 J.-L. Ménétra, Journal de ma vie (Paris, 1982) p.80

${ }^{418}$ Brunet, Le Roussillon pp.527-31
} 
way of reaching the people. ${ }^{419}$ Literate members of the lower classes learnt to read and write in French, with perhaps a smattering of Latin to assist at church services. Jean-Joseph Esmieu, the son of a smallholder from the village of Méolans in Provence who became a peddler and travelled across the region during the Revolution, wrote his memoires in a French devoid of most punctuation but shot through with 'provinçalisms'. Writing in dialect was generally an amusement for the bourgeois poet, or confined to religious instruction manuals. ${ }^{420}$

According to the commentators of the period, the lowest levels of bilingualism were found amongst the minorities who spoke a non-romance variety- that is to say in lower Brittany and the French Basque country. The prefect of the Basses Pyrénées observed that the while French and literacy had made impressive progress in the Béarnais speaking parts of the department, the Basque population generally spoke only their own language, and the great difference between this tongue and French rendered progress in public education a challenge. ${ }^{421}$ Educators in Brittany expressed the same concern about Breton as an obstacle to their work during the nineteenth century. ${ }^{422}$ Yet the French language here was still regarded as a prestige form and was frequently spoken in urban areas. Despite an abortive attempt in the 1790s, the first bilingual French and Breton journal only appeared in 1833, lasting only a year, and it was not until the 1840s that Breton-language printing really took off outside religious publications. ${ }^{423}$ Arthur Young, travelling in France during the Revolution, only mentions encountering 'bas-Bretons' with their clogs, large trousers and distinctive language in Landivisiau on market day, when they visited the town to sell their cattle. ${ }^{424}$ The republican politician Jules Simon recalled the hostility of the largely monolingual Breton peasants of

\footnotetext{
419 J. Maciak, 'Learning to love the Republic: Jacobin propaganda and the peasantry of the Haute-Garonne', in European Review of History vol. 6 no. 2 (1999) pp.171-174; F. Pic 'Essai d'inventaire des textes en Occitan de la Période Révolutionaire', H. Boyer, G. Fourier, P. Gardy, P. Martel, R. Merle and F. Pic, Le Texte Occitan de la Période Révolutionaire (Montpellier, 1989) pp. 25-27

${ }^{420} \mathrm{P}$. Martel 'La langue (les langues) d’Esmieu', La vie pénible et laborieuse du colporteur Esmieu (Barcelonnette, 2002) p.199

${ }^{421}$ E. de Serviez, Statistique du département des Basses-Pyrénées (Paris, 1802) pp.128-9

${ }^{422}$ Furet and Ozouf, Reading p.283

${ }^{423}$ Y. Le Berre, La littérature de langue bretonne : Livres et brochures entre 1790 et 1918 (Brest, 1994) pp.77, 91

${ }^{424}$ A. Young, Travels in France during the years 1787, 1788 and 1789 vol.1 (Bury St. Edmunds, 1792) pp.85-6
} 
Saint-Jean-Brévalay towards French speakers after his family moved to the village from Lorient, but also that one of the defining characteristics of the Breton parish priest's elevation to the status of notable was the French he learned in the seminary. ${ }^{425}$ French, in short, was understood as the prestige variety even in these areas where it was less solidly implanted.

These areas of French linguistic dominance may have varied in the precise distribution of communicative functions between languages, and in the levels of bilingualism amongst members of the community. However, they represented an evident contrast with those regions where languages other than French functioned as the prestige variety. In the Ligurian department of the Apennins, one correspondent described a situation similar to that across much of France, except with Italian functioning as the prestige language: 'la pratique des dites dialectes n'est établie que pour la communication verbale des habitans et jamais pour la correspondance en écriture. La correspondance dans tout le dépt. [sic.] se tient en idiome Italien' ${ }^{426}$ The broad strokes of a sociolinguistic geography of the Empire were clear- with a Francophone core surrounded by a zone of varying degrees of French bilingualism and finally the linguistic marches where French would have to compete with other varieties for the role of dominant language.

\section{Diglossia, Language Shift and Linguistic Strategies}

This type of linguistic practice has led a number of scholars of the linguistic history of France, to employ the term diglossia to describe the relationship between French and the other varieties spoken within the national territory. ${ }^{427}$ The Bergère-Monsieur dialogues that appear in the correspondence gathered by the Coqueberts and the work of later nineteenth century folklorists reveal how French formed part of the communicative repertoire across Romance speaking France during the Napoleonic period, fulfilling the role of the ' $\mathrm{H}$ ' variety alongside the local dialects that

\footnotetext{
425 J. Simon, Premières années (Paris, 1901) pp.16-7, 91-3 ; cited in Singer, Village Notables p.17

${ }^{426} \mathrm{BnF}$ Naf 5910 Observations sur les différents dialectes du département des Apennins f.100

${ }^{427}$ Above all Lodge, Dialect to Standard p.205
} 
were spoken as ' $L$ ' varieties. In Charles Fergusson's original definition, the $H$ variety was generally characterized by formalized grammatical and orthographic rules and used for official and written functions, and an ' $L$ ' variety, used for quotidian, informal and intimate communication. ${ }^{428}$ Those who translated the parable for the Coqueberts would have readily identified with the idea that patois lacked standardization- indeed many complained themselves about the lack of written grammars and dictionaries impeding their work.

It is important, however, that this term be employed with precision. As Alan Hudson has observed, careful distinctions need to be maintained between types of societal bilingualism and diglossia. ${ }^{429}$ In his formulation, the $\mathrm{H}$ variety should possess no native speakers for a situation to be considered a genuine diglossia, something that generally comes about when societies adopt a very standardized linguistic norm that differs substantially from the spoken vernacular, or where the spoken vernacular has changed substantially, leaving the $\mathrm{H}$ variety as a very distinct variety. In a situation of diglossia, according to Hudson's definition, code-switching is context dependent, whereas societal bilingualism is characterized by asymmetrical communicative practices, where elites are characterized by their use of the $\mathrm{H}$ variety. The term diglossia need not be jettisoned entirely, with Francis Britto drawing a similar distinction between 'use-oriented' and 'user-oriented' forms of the phenomenon. ${ }^{430}$ As the correspondence collected by the Coqueberts shows, this is a useful concept for understanding the linguistic situation under Napoleon, as those areas where French and dialect coexisted as $\mathrm{H}$ and $\mathrm{L}$ varieties seem to show not only communicative context but also social status determining linguistic practice. The Bergère-Monsieur dialogues make this clear, with linguistic difference used as a mechanism to represent social status.

This classification of the various sociolinguistic situations within the Empire is crucial to understandings of the ways in which the linguistic demands of the Napoleonic state were formulated

\footnotetext{
${ }^{428}$ Fergusson, 'Diglossia', in P.P. Giglioli (ed.) Language and Social Context (Harmondsworth , 1972) pp.235-7

${ }^{429}$ Hudson, pp.21-3

${ }^{430}$ Britto, Diglossia p. 40
} 
at the centre and negotiated on the ground. Above all, it is important to recognise that the linguistic geography revealed by the distribution of bilingual dialogues in popular song and the translations of the parable of the prodigal child was formed as much by social practice as it was by political history. The French state of the Ancien Régime had indisputably encouraged the spread of French as a prestige form. Yet French as a prestige form went beyond the borders of France. In parts of Switzerland, present day Belgium and northern Italy, the language of Paris was the prestige variety, spoken alongside the local dialect or patois. Similarly, standardized Italian, German and Dutch also functioned as ' $\mathrm{H}$ ' varieties in relation to dialects. The linguistic boundaries between Italian, French, German and Dutch cut across political borders because these languages were not simply 'state' or 'national' languages, but prestige forms, whose position within given linguistic communities emerged from complex historical and social processes, of which the influence of the state was but one factor. Without an understanding of this complex geography, and indeed sociology, of linguistic practice writing the linguistic history of the Napoleonic empire would be impossible. 


\section{Francisation and Linguistic Patrimony: Language, State and Local Knowledge under Napoleon}

The alignment of linguistic difference with the notion of popular culture and the low social status of regional languages shaped not only the way contemporaries understood state directed projects aimed at linguistic centralization but also the strategies they pursued when placed under pressure to conform linguistically by the centre. In October 1806, Charles Emmanuel Micoud d'Umons, the freshly installed prefect of the Belgian department of the Ourthe, responded to the Coqueberts' requests for information on the language of the region with a letter reflecting on the slow progress of attempts to spread the national tongue. According to Umons, these efforts could be traced back to the Revolution. As the prefect wrote, 'M. Grégoire, membre de la convention nationale fis, au mois de prairial l'an 2, un rapport détaillé sur la nécessité de généralisé l'usage de la langue française ; cette nécessité se fait encore plus sentir depuis que la France est de nouveau agrandie'. ${ }^{431}$ Yet even in Liège and the surrounding countryside, where the population spoke Walloon, a Langue d'oil closely related to French, the task was proving a challenge. Umons noted that his predecessor had thought to turn the education system to this purpose, but without great success. 'On est toujours attaché à l'ancien langage', he lamented, 'et ce sera qu'avec le temps que I'on pourra parvenir à l'oublier si même on y parvient jamais'. ${ }^{432}$

In these few lines, Umons offers the historian a glimpse into the dynamics of the language question during the Napoleonic period. The Revolutionary project of remaking the French and their state was not wholly diminished by the coup d'état of Brumaire or the coronation of Napoleon as Emperor in 1804. Even as Grégoire's fervent Republicanism, Gallicanism and Egalitarianism left him increasingly isolated on the Parisian political scene, his admonitions to regenerate the population of France through a shared tongue appeared more pertinent than ever as the expanding borders of the Empire made its population ever more linguistically diverse. ${ }^{433}$ The administrative partisans of francisation considered this a struggle against the inertia of tradition- against the 'old language'. The

\footnotetext{
${ }^{431}$ An F17 1209 Préfet de l'Ourthe to Ministre de l'intérieur 4 Oct. 1806

432 Ibid.

${ }^{433}$ Sepinwall, The Abbé Grégoire pp.160-2
} 
school, bastion of correct language, was considered an important tool. Yet the experiences of the interceding twelve years had revealed just how immense a task it was to remake society.

As this chapter will argue, this impulse towards the 'modern' and the countervailing weight of tradition informed not only the Napoleonic regime's linguistic politics, but the conditions under which social actors produced language. In this respect, the Coqueberts and their correspondents were exemplary of the dynamics surrounding linguistic production and its implications during the period. As Michel de Certeau has forcefully argued in his classic essay, La beauté du mort, the study of popular culture has not always been the innocent pursuit of the intellectually curious. The very concept implies a normative judgement, for the term itself is meaningless beyond its relationship to a putative elite culture. ${ }^{434}$ The study of the culture of the people has very frequently taken on a Janus faced character- as both an act of preservation and a prelude to censure. ${ }^{435}$ As the previous chapter showed, the idea of popular culture was used by the Coqueberts and their respondents to define their object of study. The ambiguities of collecting popular speech run through the correspondence, for popular also meant non-standard and uncultivated.

Historical understandings of the language question under Napoleon must embrace the ways in which individual speakers positioned themselves in relation to political and social structures- to the growing nation state and a system of social stratification that prized the corrected language of the schoolroom over the 'corrupted' patois of the popular classes. The pursuit of distinction, alignment with the nation, the state or with a high social status, meant the careful regulation of bodily practices like language. To be French, enlightened and successful meant speaking the language of high status Parisians. ${ }^{436}$ However, as this chapter will argue, responses to such pressures cannot be reduced to conformity or resistance to dominant norms. The Coqueberts themselves were more open to the notion that these 'patois ou dialects' might in fact merit the status of languages

\footnotetext{
${ }^{434}$ M. de Certeau, D. Julia and J. Revel 'La beauté du mort', M. de Certeau Le culture au pluriel (Paris, 1980) ${ }^{435}$ Certeau et. al., 'beauté' ; N.Z. Davis Society and Culture in Early Modern France : Eight Essays (Stanford, 1975) pp.258-62

${ }^{436}$ S. Bianchi, La révolution culturelle de l'an II: élites et peuples (Paris, 1982) p.197
} 
than figures such as Grégoire. In the 1831 publication on the subject they claimed that 'le Languedocien et le Provençal, [...] seraient sans doute au rang des langues à aussi bon droit que I'Espagnol et l'Italien si les cours des comtes de Toulouse et de Provence avaient subsisté, et si les Troubadours avaient eu des successeurs d'une égale réputation' ${ }^{437}$ In a manuscript on the 'limites de la langue française', which dates from after the restoration to judge from the use of the term 'royaume' in place of 'Empire', Charles-Étienne went further, claiming that 'le Catalan merite [sic.] aussi bien que le provencal [sic.] et le languedocien le nom de langue pluto-que [sic.] celui de Patois, si l’on awarde [sic.] cet honneur aux idiomes qui ont été parlé, à la cour des princes, employé dans les actes publics et cultivés par de bons écrivains' ${ }^{438}$ This notion of linguistic diversity as an element of cultural patrimony was elaborated by the kinds of local notables- state administrators, clergymen, legal officers and educators- themselves ensconced in both local and national social structures. They articulated a vision of their mother tongues as central to their sense of self. Confronted by the impulse towards modernization and linguistic integration, they developed arguments in favour of particularism that ranged from the practical difficulties encountered by cultural centralization bemoaned by figures such as Umons to the valorisation of language as heritage. In doing so they sought a relationship between centre and periphery that went beyond the dichotomy of subordination and resistance, one which would secure their place as cultural intermediaries and which was eventually reflected in the linguistic policy of the Napoleonic state.

\section{Linguistic Stigma and the Value of Standardized Language}

Such attitudes towards language shaped communicative practice. Speakers of languages other than French often induced a mixture of derision and anxiety amongst Francophone elites. When the Coqueberts sought information about the linguistic situation in the south eastern department of the Pyrénées Orientales, the sécretaire générale de la préfecture, a man named

\footnotetext{
${ }^{437}$ Coquebert de Montbret, 'Essai' p.27

${ }^{438}$ BmR Ms. Mbt. 872 (Notes de M. de Montbret sur le Patois) f.9
} 
Delon, was eager to share the findings of his own research on the language of the 'Gitans' or Roma living in the area. In order to collect linguistic samples, Delon had summoned members of the community to the prefecture. The first subject that he called was Spanish in origin, but Roma through his mother, and far exceeded his expectations because 'quoiqu'il vive avec les Gitanes, qu'il soit, comme eux, tondeur de mules et brocanteur, il leur est bien supérieur par l'intelligence. Il parle français, sait lire et écrire, chose extrêmement rare parmi eux'. ${ }^{439}$ Delon had this man translate a list of basic terms into the Gitans' language, and then summoned two other Roma to his office, a father and son who lived in Perpignan and, like his first subject, worked as sheep shearers and rag and bone men. According to Delon, these men initially appeared anxious, 'un peu embarrassés', and denied that they were even members of the community:

Ils se sont empressés de me dire ils n'étoient [sic.] point Gitanes (c'est à dire Égyptiens, Bohïmins) qu'ils étoient [sic.] nés à Figuras en Espagne, chrétiens et bons Catholiques ; et pour le prouver, ils m'ont fait voir sur leurs bras des empreintes de croix et autres signes de religion, et divers cicatrices du même genre, formés avec de la poudre à canon qu'on fait bruler sur la peau. ${ }^{440}$

Their caution at such a meeting would have been entirely understandable. The Roma people or 'Gitans' had been persecuted in France throughout the seventeenth and eighteenth centuries. Between 1682 and 1700 Roma men were sent to the galleys without trial, whilst laws against begging and vagabondage continued to be directed against them throughout the eighteenth century. ${ }^{411}$ Such persecutions had taken place in the recent past. In 1803 six hundred 'Bohémiens' were arrested in the Basses Pyrénées with the intention of deporting them to Louisiana. ${ }^{442}$ Delon, setting out to calm his guests, spoke to them 'avec la plus grand douceur,' reassuring them that the government was interested in their language, that he believed them when they told him they were

\footnotetext{
${ }^{439}$ BnF Naf 5912 Delon, Secrétaire perpétuel de la préfecture des Pyrénées Orientales au Ministre de I'Intérieur, 4th Jan. 1808

${ }^{440}$ BnF Naf 5912 Delon, Secrétaire perpétuel de la préfecture des Pyrénées Orientales au Ministre de I'Intérieur, 4th Jan. 1808. 'Bohïmins' or 'Bohémiens' and 'Egyptiens' figured amongst the varied ethnonyms given to the Roma in France during the period. See Courthiade, 'Le rromani' in Kremnitz (ed.), Histoire Sociale p.569

${ }^{441}$ J.-P. Liégois, Roms en Europe (Strasbourg, 2007) pp. 109-110

442 J. Destrem, Les déportations du Consulat et de l'Empire, d'après les documents inédits (Paris, 1885) pp. 299301
} 
Spanish in origin, and that they followed the Christian religion. Delon persuaded these two Roma to translate the same list of words as his first Roma guest, and then regaled them with the history of their ancestors, 'les arabes,' and their glorious domination of Spain. Delon may have confused the Moors and Roma, but the tale certainly entertained his guests ; 'la découverte de cette belle généalogie qu'ils ignoroient [sic.] complétement les flattoit [sic.] beaucoup'. ${ }^{443}$

The curious encounter related by Delon revealed how speaking French, like a grasp of literacy, could distinguish an individual as educated in the eyes of the official elites, as 'superior' in Delon's terms, but was also in some ways a paradigmatic example of just how the gaze of the enlightened scholar elaborated ethnic stereotypes. The very term 'Gitan' had a somewhat imprecise meaning at the start of the nineteenth century. Many of those who used the term referred to travellers and nomadic bands rather than a specific well defined ethnic group, as can be seen in the casual use of other ethnonyms- 'Égyptiens, Bohémiens'- by Delon's interviewees. ${ }^{444}$ Yet despite this lack of clarity, Delon seems to be constructing an image of 'ce peuplade,' or at least some of their more prominent traits, such as the pious tattoos, typical occupations like sheep shearing and selling bric-a-brac, and a proud Arabic lineage. However, the most striking, perhaps even unsettling, characteristic of these 'Gitans' was their language. Like the notorious thieves' cant of early modern England, their unfamiliar tongue was often perceived as threatening, inviting deception and trickery, perhaps even employed exclusively for such ends. ${ }^{445}$ Delon, having conducted his interviews, asserted that such fears were overblown; 'il m'a paru qu'on les accuse à tort de faire un mystère de leur langage particulier'. Nonetheless, the orientalized description and threatening aspect of this linguistic difference remained. Delon observed that this language, 'très rude et gutturale comme

\footnotetext{
${ }^{443}$ BNF NAF 5912 (Patois de la France III- Oise- Haute Vienne) Delon, Secrétaire perpétuel de la préfecture des Pyrénées Orientales au Ministre de l'Intérieur, 4th Jan 1808

${ }^{444} \mathrm{~J}$.L. Olive, 'Nomination et dé-nomination de l'autre : des usages ethnonymiques à l'épistémologie discursive en milieu gitan' dans Esprit critique vol.6 no.1 (2004) pp. 128-130

${ }^{445}$ A. Fox, Oral and Literate Culture in England, 1500-1700 (Oxford, 2000) pp.95-6
} 
celle des arabes', was only used by those who spoke it 'dans les foires et les marchés lorsqu'ils veulent ne pas être entendus'. ${ }^{446}$

The regional languages of France were treated with equal disdain by many members of the Francophone elite, for whom the local 'patois' was crude and ugly. One individual, writing to the Coqueberts from the canton of Saint-Amant-Tallende in the Puy du Dôme, dismissed poetry written in the local dialect because he considered local speech so unpleasant; 'Il se fait des vers dans cet idiome ingrat, nous allons en citer quelques-uns assez expressifs, mais en sons, bien rudes' ${ }^{447}$ Speaking a regional language was frequently regarded as a sign of backwardness, a lack of education and low social status. In his essay on the dialects of the Lot et Garonne, Lafont du Cujulà made clear that he was discussing primarily the 'dernières classes de la société considérées même loin des villes populeuses' ${ }^{448}$ This was, Cujulà explained, because the inhabitants of the countryside were isolated from social and cultural change. As he wrote, 'le peuple des campagnes conserve seul pendant des siècles son idiôme, ses usages, ses préjugés'.

The use of regional languages was also understood in gendered terms. Contemporaries frequently associated patois with the domestic sphere, and consequently with female speech. One member of the Société d'émulation of the Hautes-Alpes observed that the seasonal migration of male agricultural labour had little impact on the language of the department, because 'les hommes reprennent bien vite leur langue naturelle auprès des femmes et des enfans qui perpétuent sans altération du moins sensible le patois'. ${ }^{449}$ In his Notice sur Montpellier, first published in 1802 , Charles de Belleval claimed that French had gradually become far more common in the city, a result of greater wealth and education, of the increased popularity of reading and the establishment of a theatre. However, in earlier periods the vitality of the patois had depended on the women of the

\footnotetext{
${ }^{446}$ BnF Naf 5912 Delon, Secrétaire perpétuel de la préfecture des Pyrénées Orientales au Ministre de I'Intérieur, 4th Jan 1808

${ }^{447}$ BnF Naf 5912 Traduction de la parable de l'enfant prodigue selon Saint-Luc en patois du canton de SaintAmant-Tallende f.51

${ }^{448}$ BnF Naf 5911 C.N. Lafont du Cujulà, Notice sur le langage \& les usages particulières du département de Lot \& Garonne f.265

${ }^{449}$ BnF Naf 5910 Rey, Notions abrégés du dialecte Briançonnais f.77
} 
city. In the previous century, according to Belleval, 'un très-grand nombre de femmes des plus distinguées même, par leur état ou leur fortune, ne parlaient guère que le patois' ${ }^{\prime 450}$ Patois had thus remained the domestic language, 'la langue du déshabillé' even for men who practiced French in ceremonial or public contexts. How else, asked de Belleval, would they have communicated with their wives?

While a man speaking patois was considered by some ill-educated and crude, a woman was able to maintain a degree of charm, even perhaps elegance, in the local language. As J.J. Lacoste remarked of the Gascon spoken in the Lot et Garonne, 'le langage de certains paysans écorche les oreilles et ressemble au plus dur Baragouin du plus lourd allemand que sa femme dire les mêmes phrase ; vous remarquez dans sa prononciation, une certaine douceur, une certaine harmonie qui charment'. ${ }^{451}$ Joseph Lavallée, who was in the habit of reviewing the womenfolk of the towns he visited for his readers, offered a very favourable appraisal of those he encountered in Arles. The greatest pleasure awaiting the traveller in the town, according to Lavallée, was taking a promenade along the banks of the Rhône; 'c'est la le rendez-vous des plus jolies femmes, et elles sont en grande nombre dans cette ville'. ${ }^{452}$ Lavallée was enamoured of the women of Arles. His list of their appealing physical attributes- their beautiful brown hair and eyes, their well-proportioned bodies and graceful movements- was crowned by their use of dialect, by what Lavallée described as 'une douceur enchanteresse dans leur patois : le ton le pus caressant, l'accent le plus séducteur'. ${ }^{453}$

Female dialect speech was enchanting only to a point. Within the 'masculine' spheres of public discourse and writing, using French, and using French correctly, was crucial to successful participation. Lafont du Cujulà criticized the writing of the women of the Lot-et-Garonne, observing how the 'Italiante' influence of the local language encouraged 'I'habitude presque générale à nos femmes à moins qu'une excellente éducation ne l'ait corrigé, d'écrire le $\underline{L}$ mouillé à la manière des

\footnotetext{
${ }^{450}$ C. de Belleval, Notice sur Montpellier (Montpellier, 1804) pp.16-17

${ }^{451}$ BnF Naf 5911 J.J. Lacoste, Essai sur les dialectes Du département de Lot et Garonne f.252

$452 \mathrm{~J}$. Lavallée and J.B.J. Breton, Voyage dans les départements de la France (5 vols., Paris, 1792-1802) i, p.18

453 J. Lavallée et. al., Voyage i, p.16
} 
Italiens' ${ }^{454}$ Like Joseph Lavallée, the justice of the peace of Montbron associated patois with female urban sociability, but found the practice more shocking than seductive. He recalled how, 'à Perigeux, capitale du département de la dordogne, je ne fut jamais plus surpris, que d'entendre par un Beaujour de promenade différentes dames de la ville en grande toilette qui conversaient en patois' ${ }^{455}$ For the prefect of the Nièvre, female dialect speech should still ideally betray schooling; 'ce patois est assez agréable dans la bouche des femmes qui ont reçu une certaine éducation et qui le parlent bien, mais il est détestable à entendre dans celle des francs et rustiques morvandeaux' ${ }^{456}$

The field of Revolutionary politics was often considered the exemplary instance of the Francophone public sphere. Participation in these gatherings, it was argued, encouraged the spread of French. Bastide, the conseiller de la préfecture of the Haute Garonne, claimed that; 'dans les villes et dans tout le pays qui les entoure, l'idiome vulgaire subit peu à peu des changements qui le rapprochent de la langue nationale' ${ }^{457}$ Bastide thought this was the result of Revolutionary political culture, since 'le désir de se distinguer était un effet nécessaire de ces réunions, et l'effet peut-être subsiste encore après la cause. On a senti partout le besoin d'entendre et de parler le français' ${ }^{458} \mathrm{~A}$ similar claim was made of the 'patois Cauchois' spoken in Normandy. An anonymous essay sent to the Coqueberts described Cauchois as little more than 'un français defiguré mais toujours très reconnaissable'. ${ }^{459}$ The prefect, however, claimed that it had 'éprouvé une amélioration sensible, qu'il est devenu moins inintelligible et que les étrangères n'ont plus besoin d'interprète pour se faire entendue ni pour le comprendre eux-mêmes'. ${ }^{460}$ This was was due above all to 'I'habitude et la nécessité de lire les nombreuses lois, les arrêtés en tout genre, dont les placards taisaient les murs

\footnotetext{
${ }^{454}$ BnF Naf 5911 Lafont du Cujulà, Notice sur le langage f.267

455 BnF Naf 5910 Juge de paix de Montbron au Ministre de l’intérieur, 13 Mar. 1810 f.223

${ }^{456}$ BnF Naf 5911Maury, préfet de la Nièvre, to Ministre de l'Intérieur,

${ }^{457} \mathrm{BnF}$ Naf 5911Conseilleur de la préfecture de la Haute-Garonne au Ministre de l'Intérieur, 21 Apr. 1810 f.15

${ }^{458}$ BnF Naf 5911 Le Conseilleur de la préfecture de la Haute-Garonne au Ministre de l'Intérieur, 21 Apr. 1810 f.15

${ }^{459}$ An F17 1209 Observations générales sur l'idiome Cauchois

${ }^{460}$ An F17 1209 Préfet du département de la Seine Inférieur au Ministre de l'Intérieur, 31 Jan. 1812
} 
de toutes les communes, les feuilles publiques, qui venaient journellement exister ressentir la curiosité de tous les citoyens'. ${ }^{461}$

The evocation of Revolutionary politics as a catalyst for linguistic change highlights the common assertion amongst contemporaries that 1789 marked a profound historical cleavage. The sub-prefect of the arrondissement of Montélmar in the Drôme claimed that 'depuis la Révolution, dans la cy devant [sic.] Provence, dans le Languedoc et dans la partie méridionale du Dauphiné, l'idiome patois est d'un usage un peu moins général' ${ }^{462}$ This change could be attributed to two causes. Firstly, troop movements and the circulation of travellers had become increasingly common, forcing the population to interact with French speakers with greater frequency. Secondly, according to the sub-prefect, 'le retour des militaires sur leurs foyers ont dû porter, à la langue française, I'application d'un certain nombre d'individus'. Both these assertions were echoed by Bastide, who claimed that, along with the political reunions of the Revolution, French had been spread by the 'mélange fréquent des habitans [sic.] des divers pays [...] dans les armées et les levées en masse' ${ }^{463}$

It is impossible to quantify the impact of the Revolution on the linguistic capacity of the French population. The local administrators whose testimony is cited above may have presented a deceptively optimistic picture in order to convince Paris of the efficacy of their administration, although equally a linguistically diverse population might have provided an excuse for sluggish correspondence or buttress claims for greater resources. Nonetheless, the testimony does clearly demonstrate the association of French with progress and of patois with an old regime in the process of being swept away. Language was evidently a bodily practice marked as politically, as well as socially, significant. At least for a number of those who wrote to the Coqueberts or who penned travelogues or statistical essays, speaking French carried associations of social and political progress.

\footnotetext{
${ }^{461}$ An F 171209 Observations générales sur l'idiome Cauchois

462 BnF Naf 5910 Sous-préfet de Montalimar au Min. de l'Int. 29. Jul. 1808 f.352

463 BnF Naf 5910 Le Conseilleur de la préfecture de la Haute-Garonne au Ministre de l'Intérieur, 21 Apr. 1810 f.15
} 
The influence of the French language on the way speakers of the regional languages of French expressed themselves and its use as a means of achieving social distinction was evident in a description of linguistic practices in Marseille provided to the Coqueberts by Antoine Anthoine, the mayor of Marseille. Anthoine reiterated the distinction between high status French and low status regional language, claiming that only 'les gens du peuple [qui] emploient dans toute sa pureté rustique le langage provençal' ${ }^{464}$ The 'pure' Provençal spoken by the 'gens du peuple' contrasted with 'les habitans d'une classe supérieure [qui] forment [leurs mots] par dérivation du français, avec des simples changemens [sic.] de terminaisons, conforment à l'analogue provençale'. The mayor illustrated this with reference to the different words for house amongst these groups; 'ainsi pour maison, le peuple dit houstaou, les bourgeois et négociants maïsoun'. French, then, might serve to distinguish the social status of French even when speaking Provençal, for the bourgeois and merchants of Marseille, presumably more likely to speak French themselves, made use of French words in their 'Provençal francisé', as Anthoine described it. ${ }^{465}$

These strategies may be broadly understood as appeals to status, as the use of a language to distinguish oneself as educated or of high social standing, especially in the exercise of authority. In Pierre Bourdieu's analogy of the linguistic market, the 'symbolic value' of linguistic utterances is evaluated by their recipients according to different normative criteria in different communicative contexts. The efficacy of specific communicative choices depends not only on the linguistic competence of the speaker, but the attitudes of the intended recipients, which change in more or less formal situations. ${ }^{466}$ Under Napoleon, speaking or writing French correctly was in many instances a useful sign of wealth or authority. This was particularly the case when it came to appointments within the gift of the state. In his account of travelling to the Alpes-Maritimes, Papon

\footnotetext{
${ }^{464}$ BnF Naf 5910 Antoine-Ignace Anthoine, Maire de Marseille au Ministre de l'intérieur, 9 Jun. 1807 f.145

465 Linguists have distinguished between two types of language change in contact situations- substitution, where speakers make an active choice between two linguistic codes, say French and Provençal, and convergence, where speakers linguistic production over time moves towards the prestige form. The comments of the mayor of Marseille remind us that particular instances of language shift can be placed on a spectrum between these two poles, characterised to a greater or lesser extent by substitution and convergence, rather than one to the exclusion of the other: Lodge from Dialect to Standard pp.190-1

${ }^{466}$ P. Bourdieu, Language and Symbollic Power pp.76-81
} 
complained that in much of the eastern part of the department, 'I'usage de la langue française n'est pas aussi commun qu'il seroit à désirer'. As much of the education carried out across the department had taken place in Italian, 'même la plupart des fonctionnaires publics, écrivent mal le français' ${ }^{467}$ The obverse of such comments was that speaking French greatly increased one's chances of securing an office, something reflected in the frequency of claims within ministerial correspondence on appointments that a given supplicant could speak French. ${ }^{468}$

Individuals sought distinction and authority through the use of French in more subtle ways. Jules Simon, for example, recalled that, in the small village in lower Brittany in which his family spent the early years of the restoration, 'le curé faisait ses annonces dans les deux langues, mais personne, excepté nous, ne savait un mot de français' ${ }^{469}$ Such a practice would appear to have a clear performative function, demonstrating greater learning and thus distinguishing the curé from his flock.

These strategies were not open only to elites. Individuals of all classes could use French to create a favourable impression or even exercise authority. The first Gitan interviewed by Denon, for example, struck him as 'bien supérieur' thanks to his capacity to speak French. Speaking French could itself function as a sign of authority. The point can be illustrated with a digression into the trial records of the appeal court of Aix. On the $11^{\text {th }}$ of May 1810 a group of brigands robbed a shepherd's cabin and killed one of the occupants. In order to gain access to the cabin, Martinet and his companions had devised a wheeze- they would pose as gendarmes on the hunt for deserting conscripts. Every one of the witness statements concurs that as the brigands approached the cabin they shouted 'en français " Ouvrez donc parce que vous avez des conscrits $»$ '. ${ }^{470}$ Presuming the brigands to be gendarmes, one of the shepherds in the cabin opened the door, allowing the brigands

\footnotetext{
467 S. Papon, Voyage dans le département des Alpes-Maritimes, avec la description de la ville et du terroir de Nice, de Menton, de Monaco etc. (Paris, 1804) p.103

${ }^{468}$ See ch. 5

${ }^{469}$ Simon, Premières années p.16

${ }^{470}$ AdBdR 2 U 21067 (Fonds de la cour d'appel d'Aix) Procès contre Louis Martinet, dit 'l'Ecorche Rosse,' prévenu du vol et d'assassinat
} 
to enter. However, as soon as the occupants realised their error, noting the costume and blackened faces of the presumed gendarmes, a scuffle ensued. Two of the shepherds fled the cabin and took off in different directions. One was pursued and shot dead by two of the brigands; the other made it to the road and headed to the nearest town to find help. In the commotion the remaining two brigands were forced out of the cabin, and the door locked behind them, leaving two shepherds and a twelve year old field hand inside. The statements of the three remaining occupants alleged that the brigands then threatened to burn down the cabin, unless they were allowed back in. According to the testimony of the 12 year old field hand, Étienne Vernet, they cried 'en idiome provençale "Double dieu nous allons mettre le feu à la Cabane».' 471 This example demonstrates the symbollic character of linguistic practice, which offered state officials a way to exercise authority. It also shows how lower status actors were equally aware of such strategies and able to imitate them, for the brigands- none of whom was literate- used French to 'disguise' themselves as gendarmes.

Individual speakers of regional languages who attempted to 'franciser' their speech in an attempt to convey an impression of education and social status risked derision and mockery if their language was not considered up to the Parisian standard. Louis-Aubin Millin, in his account of travelling through the south of France during the Napoleonic period, recounted the numerous 'provençalismes' of his fellow travellers on a ferry travelling down the Rhône from Tarascon to Arles. One passenger, according to Millin, enquired of another, 'combien y a-t-il [...] que vous manquez de Marseille', which Millin corrected to 'que vous avez quitté Marseille'.${ }^{472}$ The reply came in a French that appeared equally suspect to Millin ; 'trois semaines ; j'ai été en Avignon, [...] et je vas à Arles' ${ }^{473}$ A third passenger reassured the Parisian antiquary that Arles would satisfy his interest in architecture- 'vous y verrez beaucoup de belles estatues' ${ }^{474}$ Millin hypothesised that these

\footnotetext{
${ }^{471}$ AdBdR 2 U 21067 Procès contre Louis Martinet, dit 'l'Ecorche Rosse,' prévenu du vol et d'assassinat 472 A.L. Millin, Voyage dans les départemens du midi de la France, (5 vols., Paris, 1807-1811) iii, p.471

${ }^{473}$ Millin, départemens du midi iii, p.468

${ }^{474}$ Ibid. iii, p.470
} 
'provençalismes' arose because individuals habitually spoke Provençal which in turn made itself felt when they spoke the national language. This would appear a plausible hypothesis, and example of 'interference' in the jargon of linguistics. 'Estatues', for example, is a direct lexical port from Provençal, while confusion over prepositions- 'en Avignon' for 'à Avignon' - was a frequently remarked feature of southern French speakers. ${ }^{475}$ Yet while Millin ascribed this to the habit of speaking Provençal, the striking feature of the scene he described was the use of French. The language was clearly the language of public discourse when travelling in Provence, even between Provençal speakers, as in the first exchange cited above. Yet these speakers found their language corrected in the journal of their educated, Parisian companion.

Regional speakers of French had to be wary of becoming the butt of a joke when they spoke the language of Paris. The question of provincial accents was distinct from that of patois in one crucial way. While patois frequently connoted low social status as the language of the urban labourer or rural dweller for contemporaries, individuals of all classes could be accused of speaking French like a provincial. As Millin observed, 'ces provençalismes sont extrêmement fréquens,[sic.] même parmi des gens qui ont reçu quelque éducation et qui ont fait des études' ${ }^{\prime}{ }^{476}$ This could become an obstacle for speakers who wished to participate in public discourse and were obliged to do so in French. In an account sent to the Coqueberts in April 1810, the conseilleur de la préfecture of the Haute Garonne was keen to dispel the negative myths surrounding the speech of Toulouse:

Ce qu'il y a de certain, c'est que les personnes qui parlent le français avec un mélange plaisant de muets et de tours gascons et avec cet accent qui excite le rire dans nos spectacles, tout devenues plus rares à Toulouse et sans doute ainsi dans les autres villes de cette contrée. Un comédien qui viendrait chercher ici des modèles en ce genre, en trouverait moins aujourd'hui et de moins saillant qu'autrefois. ${ }^{477}$

\footnotetext{
${ }^{475}$ F. Mistral, Lou tresor dòu Felibrige ou dictionnaire Provençal-Français (2 vols., Arles, 1878) ii, p.1055 ; Desgrouais, Les gasconismes corrigés (Toulouse, 1819) pp.1-8

476 Millin, départements du midi iii, p.471

${ }^{477}$ BnF NaF 5911 Conseiller du Préfecture de la Haute-Garonne au ministre de l'intérieur 21 avril 1810
} 
Speaking in a 'provincial' manner was a well-established comedy device on the Parisian stage during the period. In the character notes for his comic-opera Le premier venu, ou six lieues de chemin, first performed in Paris in 1810, the playwright Jean-Baptiste-Charles Vial stipulated that one character, Juliette, should be played with a Provençal accent. ${ }^{478}$ Such techniques were not always well-received by critics. The play's reviewer in the Journal des débats was scathing about the actress's performance, lambasting her for putting on an accent which served only to obscure her lines. ${ }^{479}$ Nonetheless, the mirth-inducing potential for regional speech was clear, and must have weighed on bilingual speakers when they attempted to converse in French, potentially undermining whatever impression of education or social status such an act might convey.

The anxiety of such speakers was reflected in the proliferation of style manuals correcting regional speech from the middle of the eighteenth century. The oldest, and most famous, of these manuals was Desgrouais' Les gasconismes corrigés, published in Toulouse in 1766, although in offering a collection of common errors committed by southerners in French Desgrouais was echoing the terms used by many compilers of regional language dictionaries to justify, and presumably to sell, their works. The cover of the Provençal-French dictionary published in 1723 by a member of the order of Minimes named Pellas promised the reader that the book would serve 'pour l'instruction des Provençaux qui n'ont pas une entiere [sic.] intelligence ni l'usage parfait de la langue Françoise [sic.] ${ }^{4}{ }^{480}$ The Abbé Bossier de Sauvages opened his 1756 Dictionnaire languedocien-françois by explaining that the book was intended to correct the errors that littered the speech of the inhabitants of Languedoc, errors committed not only by members of the popular classes, but 'aussi celle des honnêtes-gens qui ont été élevés dans cette Province' ${ }^{481}$ This was because most inhabitants still spoke Languedocien amongst friends or in domestic contexts, despite the progress

\footnotetext{
${ }^{478}$ J.B.C. Vial, Le premier venu, ou six lieues de chemin

479 Journal des débats et décrets, 14 prairial an IX, (06/03/1801) p.4

${ }^{480}$ S.A. Pellas Dictionnaire provençal et françois dans lequel on trouvera les mots provençaux \& quelques phrases \& proverbes expliquex en françois (Avignon, 1823)

${ }^{481}$ P.A. Bossier de Sauvages Dictionnaire Languedocien-François, ou choix des mots languedociens les plus difficiles à rendre en François (Nimes, 1756) p.vi
} 
of French as the language of literature and formal communication. Consequently, for the inhabitants of the region, Ie François, qu'ils ne trouvent guere [sic.] de mise que dans le serieux [sic.], devient ainsi pour la plûpart [sic.] une langue étrangère [...] le tour \& l'expression leur échappent, la langue du pays perce, on croit parer François, \& l'on ne fait que franciser le pur Languedocien' ${ }^{482}$ From the final years of the eighteenth century, the errors induced by this 'penetration' of French by regional languages inspired a number of style manuals in the manner of the 'Gasonismes corrigés'.

Those compiling these catalogues of linguistic error claimed their works could liberate speakers from the influence of regional languages, allowing them to pass successfully as educated French speakers. As Étienne Molard observed in the introduction to his Dictionnaire du mauvais langage, 'on ne sauroit nier qu'une élocution pure et correcte distingue, dans la conversation la plus simple, l'homme instruit de celui qui a été privé des secours de l'éducation' ${ }^{483}$ The author of a collection of Flandricismes and Wallonismes published in 1806 made an explicit connection between purifying speech and Napoleonic integration of the population explicit. As the author explained,

plus d'un motif doit déterminer aujourd'hui plus que jamais les ci-devant Belges à désirer de parler la langue française dans toute sa pureté, et de la rendre populaire. Le sort de ce pays est irrévocablement lié à celui de la France, dont il est partie intégrante. La législation, I'administration y sont une : la langue doit l'être aussi. ${ }^{484}$

The inhabitants of the Belgian departments, 'les nouveaux français' would be called to participate in the workings of the French state, as prefects and in positions demanding 'le talent de la parole'. Manufacturers and Merchants would need to present their views to the government in French. Above all, it was in the 'national language' that judges were obliged to hand down their sentences, notaries to draft testimonies and contracts, and lawyers to plead. ${ }^{485}$

\footnotetext{
${ }^{482}$ Bossier de Sauvages Dictionnaire Languedocien-François p.vi

${ }^{483}$ E. Molard Dictionnaire du mauvais langage ou Recueil des expressions et des phrases usitées en France, et notamment à Lyon (Lyon, 1797) p.iii

${ }^{484}$ Poyart Flandricismes, wallonismes et expressions impropres dans le langage français (Bruxelles, 1806)

485 Poyart Flandricismes pp.vi-ix
} 
This prejudice in favour of French was not universally shared across the Empire. Speaking French may have in many contexts functioned as an appeal to status, but it was not the only language that could be used in this manner. The author of the departmental statistics for the Belgian department of the Meuse Inférieur referred disparagingly to the Flemish spoken in the department, claiming 'c'est un idiôme qui diffère dans chaque canton. Using Dutch, as well as French, could mark one out as a member of the educated classes; 'les gens instruits substituent le hollandais, ou le français, lorsqu'ils écrivent' ${ }^{486}$ Speaking French was widely viewed, at least by many French speakers, as a route to social status, a necessary skill for office holding and a requirement for the successful participation in public discourse. Yet 'Francisation' was also a risky strategy for speakers. Elite French linguistic practice was characterised by a strict prescriptivism, and speakers who littered their French with regional forms were stigmatised for their 'gasconismes' or 'provençalismes', their 'wallonismes' or 'flandricismes'. Risking such mockery, some speakers of other languages looked to alternative models of communicative practice, to alternative rubrics against which the value of linguistic production might be judged.

\section{Beyond Francisation: Linguistic Solidarity and Covert Prestige}

Speakers under pressure to francise their language often sought to mobilise values of communitarian solidarity, and pressure was frequently exerted on speakers to eschew French in favour of the less prestigious local patois. In the Lot-et-Garonne, Charles Lafont du Cujulà claimed that using the local patois demonstrated solidarity with fellow speakers. As he wrote, 'nos paysans appellent un franciman un homme qui parle toujours ou qui affecte de parle le français' ${ }^{487}$ In addition to 'franciman', Frédéric Mistral cited 'Francihot, Francilhot, Petit Français, Méridional qui affecte de parler français, indigène qui prend l'accent du Nord' ${ }^{488}$ The naming of speakers of

\footnotetext{
${ }^{486}$ F.A. Cavenne Statistique du département de la Meuse-Inférieure (Maastricht, 1802) p.93

${ }^{487}$ BNF NAF 5911 C.M. Lafont du Cujulà, Notice sur les langages et les usages particuliers des habitants du département de Lot et Garonne f.266

${ }^{488}$ Mistral, Lou trésor i, p.1175
} 
another language - 'franciman' - as well as the notion that speaking French could be an affectation, would serve to undermine efforts to secure social distinction through the use of French. Ensuring a favourable response from listeners would mean using the less prestigious patois, thereby emphasising solidarity with the audience. Communitarian pressure influenced speakers to use patois rather than French.

Local elites who participated in Francophone culture also felt obliged to court favour through the use of patois. Lafont du Cujulà described just such a strategy, remarking that 'on emploie [...] l'idiome local, avec le paysan par nécessité, avec l'ouvrier et l'artisan des villes en signe de bienveillance' ${ }^{489} \mathrm{~A}$ similar technique might be observed in the singing of a dialect Christmas carol at the 1806 midnight mass in the chapel of Charles-Francis Ladoucette, prefect of the Hautes-Alpes. The clergy of Dauphiné had long used French in religious contexts, for sermons and catechisms. ${ }^{490}$ One imagines, therefore, that a dialect carol sung during the prefect's midnight mass had a certain symbolic value, an indulgence for those members of the congregation flattered by the use of the local language in a religious context where French was prominent.

These prominent local Francophones, who abjured French so as to demonstrate communitarian solidarity, were not subverting the linguistic prestige of French. They were engaged in what Pierre Bourdieu has referred to as 'strategies of condescension' ${ }^{491} \mathrm{~A}$ display of benevolence through the use of patois could only be effective if an audience recognised it as a departure from habit, as a speaker's linguistic choice, or perhaps even linguistic sacrifice. It turned on a shared recognition of the dominant position of French in relation to the local language, without which such a strategy would be impossible. Jules Simon recalled the nobles who returned to Morbihan during the Empire and after the restoration pursuing precisely this kind of strategy to distinguish themselves from the urban bourgeoisie who had bought up land in the region during the Revolution,

\footnotetext{
${ }^{489}$ BnF Naf 5911 Lafont du Cujulà, Notice f. 265

490 T. Tackett, Priest and Parish in Eighteenth Century France (Princeton, 1977) p.159

${ }^{491}$ Bourdieu, Language and Symbolic Power p.68-9
} 
and thus curry favour amongst the rural labouring classes: 'Les bourgeois qui ne parlaient pas breton étaient suspects par cela même. Les anciens seigneurs, les nobles [...] savaient parfaitement le breton, et ne parlaient pas d'autre langue avec leurs paysans' ${ }^{492}$ The same might be said of the strategies of resistance proffered by local communities. Invoking solidarity through the use of a particular language inevitably references its position in relation to the prestigious variety. Such strategies, embedded as they were within the existing symbolic order of languages, were thus vulnerable to those committed to the robust assertion of this order. In the Hautes-Alpes, even as the prefect watched the performance of patois carols in his chapel, the members of the Société d'émulation were drawing up lists of faulty, error strewn regional speech forms. ${ }^{493}$ Linguistic resistance based on communitarian solidarity left speakers vulnerable to the charge of linguistic imprecision, to being labelled provincial or rustic on the basis of 'vicious locutions and expressions'.

The Prud'hommes of Marseille similarly found their use of Provençal attacked as incomprehensible. In 1822, a group of fishermen of Neapolitan descent, but resident in Marseille for around a century, claimed the Prud'hommes were inventing regulations to govern fishing in the town and, without publicising the new rules, fining unsuspecting fishermen for infracting them. The victims appealed for fair treatment under the law on the basis of their common membership of the French nation - 'nous sommes français comme eux'. When the Procureur du Roi of the appeal court of Aix was sent to investigate, the Prud'hommes once again had recourse to tradition - 'd'après ces messieurs, l'institution de leur conseil se perd dans la nuit des tems' ${ }^{494}$ However, on this occasion the tactic seems to have invited more scorn than approval. The Prud'hommes had a set of regulations written in Provençal, but claimed to be forbidden from showing it to outsiders, leading the procureur to remark sardonically that the book was 'sacré pour eux comme le livre saint pour les hebreux et le coran pour les enfants de Mahomet'. When the Prud'hommes did recount some of

\footnotetext{
492 Simon, Premières années p.17

${ }^{493}$ R. Merle, 'Consulat-Empire : un laboratoire de l'aliénation occitane', in La question linguistique au sud au moment de la révolution français- LENGAS- Revue de sociolinguistique no.17 (1985) pp.348-9

${ }^{494}$ AdBdR 2 U 11227 (Cour d'appel d'Aix- parquet général) Plaintes contre le Prud'homme Pêcheurs
} 
their regulations they engendered an equally negative response; 'ils m'ont récité quelques articles de leurs règlements que je conviens être de l'Arabe pour moi'. Like appeals to solidarity, invoking tradition had its limits. Both strategies could be dismissed as trivial, irrational and 'un-French' in more formal situations, or when interacting with speakers less inclined to indulge the linguistic sentiments of local communities, for both rested upon the distinction between low status patois and the prestigious language of the nation.

\section{Mother Tongues, Linguistic Patrimony and the Napoleonic State}

While such appeals to communitarian solidarity were not always successful, the period did witness the elaboration of a powerful discourse in defence of linguistic particularity, one which prefigured later nationalist arguments in understanding the mother tongue as a fundamental feature of selfhood, invested with a deep affective significance and a route to uniquely authentic expression. Many of the local elites who themselves relied on French to assert and practice their own social authority expressed a profound attachment for the local language. Lafont du Cujulà, the sécretaire de la préfecture of the Lot et Garonne, in the Occitan speaking south-west, expressed his affection for the patois he had spoken as a child; 'nous le parlons par sentiment quand, éloignés du lieu qui nous vit naître, nous retrouvons quelqu'un de nos compatriotes. Nous nous rappelons ainsi, par une sorte d'illusion, les objets qui environnent notre berceau, les jeux de notre enfance, les sensations si profondes de la jeûnesse'. ${ }^{495}$

Cujulà's impassioned elegy to his mother tongue presented a telling shift from the third person to the first. The patois was no longer used when referring to the popular classes to describe the language 'they' spoke. In Cujulà's words, 'nous le parlons'. The defence of the local language mounted by the sécretaire de la préfecture of the Lot et Garonne, a Napoleonic bureaucrat firmly

${ }^{495}$ BnF Naf 5911 Lafont du Cujulà, Notice f.265 
ensconced within the Francophone networks of the French state, shows how misleading simplistic distinctions between the centralizing forces of modernity and resistance of traditionalists can be. Countervailing attitudes to cultural centralization developed not just in reaction to state action, but within the ranks of state actors themselves. Cujulà's nostalgic affection for this mother tongue reflected more broadly the continued importance of patois in the communicative practices of local francophone elites. Pierre Laboulinière, sécretaire général of the Hautes Pyrénées, observed that ‘le patois se prête aisément à la fine plaisanterie ; et les personnes lettrées, celles qui composent la bonne société, savent très bien l'employer à cet usage ; ils le préfèrent même, sous ce rapport, à la langue française' ${ }^{496}$ Many of these members of the 'bonne société' therefore used dialect habitually in conversation, and not simply as a means of communicating with the 'peuple':

'souvent, dans la conversation, ils entremêlent une phrase du pays avec le français, dont ils se servent pour leur narration, et cela donne du sel, du piquant, de la vivacité au discours' ${ }^{497}$

These figures remained sensitive to the charge that speaking patois was an uncouth habit, symptomatic of a lack of refinement. This can be seen in a response sent to Coquebert in 1808 by Richard, the prefectural archivist of the department of the Vosges, on the 'Patois de Neufchateu', a Langue d'oil dialect spoken in Lorraine. Richard provided a sample of his 'langue maternelle', and in line with this statement of attachment for the dialect sought to distinguish between 'coarse patois', rightly deserving of opprobrium, and 'polite patois', illustrating the difference with an exchange between a woman and her son, who had arrived home late for supper:

L'expression que cette femme grossière et revêche, mit dans sa manière de parler, (quoiqu'elle fut la femme d'un conseiller de l'hôtel de ville de Neufchâteau) et l'attitude qu'elle avait (étant appuyée nonchalamment auprès de la porte de sa maison, sur la rue) mâchant entre ses dents cassées, une croute de pain, du reste de son soupé, aussi dûre [sic.] que sa parole, me frappèrent et me firent rire. ${ }^{498}$

\footnotetext{
${ }^{496}$ Laboulinière, Hautes-Pyrénées p.294

497 Ibid., p.294

${ }^{498}$ An F17 1209 Préfecture du Département des Vosges. Patois des Vosges. Idiome de l'arrondissement de Neufchâteau
} 
The woman went on to reprimand her son for his tardiness, drawing a sardonic retort- 'j'o-n'â bin'ârou (je m'en soucie peu)', to which the woman responded with a threat, 'prot voèdie baillerâ de $\underline{m^{\prime}} n^{\prime}$ èreule pâ l'net (je te donnerai de mon balai par le nez)' ${ }^{499}$ The most striking feature of Richard's description of this scene was the association of patois with a gendered notion of domesticity- the son spoke patois with his mother despite the public (and presumably Francophone) role of her husband. While this woman, 'grossière et revêche' as she was, berated her son in the following terms; 'os-c-que t'crô qu'on t'errète pou soupè?' a polite woman would have said 'osc'que v'croye qu'on v's'è ètoudu pou soupè'. The most noticeable difference was the use of the formal address form- vous, in place of the informal tu form. As Richard explained, 'on se tutoie, par familiarité ou par mépris ; mais jamais on n'a permis aux enfans de tutoyer les parens, comme quelques personnes le permettent, en langue française, depuis la révolution. Cette manière de parler serait un crime, en pareille circonstance'. Richard's distinction between 'polite' and 'crude' patois seems to draw on 'French' norms governing communication. Yet one might also read in Richard's comments a subtle rebuke towards French; while the Revolution and all its excesses unfolded in the sphere of this language, the 'patois' seemed to stand for continuity, for traditional values such as parental authority.

Richard and Lafont du Cujulà, both French speakers with positions in the bureaucratic structures of the French state, articulated a powerful argument in favour of the use of patois in spoken communication. Regional languages and dialects were mother tongues, and carried a strong affective value and connection to the traditions of local society. Probably the clearest, and certainly the best known, elaboration of this argument during the Napoleonic period was Antoine Fabre d'Olivet's 1803 publication, Le troubadour, poésie occitanique. Olivet was a forerunner of the cultural revivalism of a number of southern scholars in the early years of the nineteenth century who sought to raise the status of their local languages by creating the accoutrements of a standardized

\footnotetext{
${ }^{499}$ An F17 1209 Préfecture du Département des Vosges. Patois des Vosges. Idiome de l'arrondissement de Neufchâteau
} 
language- a literary canon and a set of orthographic, grammatical and lexical norms to govern written production. ${ }^{500}$ Olivet was also the first to use the term 'Occitan', at least in its adjectival form 'occitanique', to describe the totality of the languages of the south. As he wrote, this term was 'un mot nouveau, adopté pour exprimer à-la-fois le Provençal et le Languedocien, et généralement tous les dialectes dérivés de l'ancienne langue $\mathrm{d}^{\prime} \mathrm{Oc}^{\prime} .{ }^{501}$ Olivet constructed a vision of his mother tongue as intimately intertwined with his sense of selfhood. Appropriately enough, he dedicated the volume to his mother ; 'c'est toi qui m'as rendu ce langage si cher, puisque c'est de ta bouche que mon cœur en a reçu les premiers élémens [sic.], et que c'est sur ton sein que mes lèvres débiles en ont appris les premières sons' ${ }^{\prime}{ }^{52}$ For the literate and French speaking, however, this was a complicated position to take, and Olivet was not prepared to abandon his claim on learned Francophone status. After all, his work was a translation into the French, intended to inform a learned French speaking audience of the glories of a (fictive) medieval poet, and as he was quick to assert, his mother would have been able to judge the quality of his translations 'puisque'à l'usage habituel du dialecte languedocien, celui de tous qui se rapproche le plus de l'idiôme occitanique, tu joins une connaissance parfaite de la langue française'.$^{503}$

The idea that regional languages formed an integral part of the selfhood of those that spoke them, even if they were also Francophone, was understood by many as a kind of awakening, stimulated by the rising interest in the language and culture of the population during the period. Le Fur, a clergyman from Finistére who was named Rector of Plougouverst at the concordat then curé of Landernau, and who translated the parable into Breton for the Coqueberts in 1811, wrote with a touch of shame that 'quoique le bas-breton soit ma langue maternelle, je n'en ai jamais fait une

\footnotetext{
${ }^{500} \mathrm{~F}$. Zantedeschi, Une langue en quête d'une nation: Le débat sur la langue d'oc au XIXe siècle, unpublished PhD thesis, European University Institute, (2009) p.104

${ }^{501}$ Olivet Le Troubadour i. p.1

502 Ibid., i. p.i

${ }^{503}$ Ibid., i. p.i
} 
étude particuliére'. ${ }^{504}$ This sense amongst Francophone speakers of regional languages that one should devote greater attention to the mother tongue was expressed more forcefully by another Breton translator of the parable, Alexandre-Marie Joguet, curé of Ploudiry, who adopted an apologetic tone in explaining that like other men of some status within the local community, the 'bonnes gens' in his words, he had not devoted studies to the language and spoke Breton badly, only by routine. Of his translation of the parable, he wrote 'je vous livre ce moment de ma honte et de mon insouciance sur la langue maternelle' ${ }^{\prime}{ }^{55}$ This attitude was particularly clear amongst the Breton speakers involved with the Académie celtique. Even as prominent members like Jacques Cambry bemoaned the backwardness of rural Brittany, others articulated the value of the Breton language as a foundational component of their identity. Claude Lecoz, the constitutional bishop who was granted the Archdiocese of Besançon after the concordat, wrote that he had always cleaved to the title of 'breton, bretonnant', and exulted the study of Breton carried out by the Académie and formerly by his 'ami' Théophile Malo de la Tour d'Auvergne. Such efforts, he claimed, would save the language from ignominy by reconnecting it with the glories of the Celtic past; 'grâces à l'académie la langue celtique jusqu'ici méprisée, négligée ou méconnait, est devenue l'objet des recherches des savans' ${ }^{506}$ As with Olivet, the effort to construct the language and its heritage as a space for the elaboration of a cultural identity was coupled with an ambiguous relationship to the French speaking centre. La Tour d'Auvergne was also a signal example in this respect. The 'premier grenadier' of the French armies, who was killed in battle at Oberhausen in Bavaria, was also an avid celtomaniac. His Origines gauloises, a panegyric to the Celtic antiquity of Breton, was intended as a kind of monument to the glory of his patrie, a documentation of the 'ruines d'un grand édifice', which

\footnotetext{
${ }^{504}$ D. Bernard 'Une enquête ministérielle sur les dialectes bretons sous le Premier Empire', Annales de Bretagne, vol.60 no.1 (1953) p.80

505 Bernard 'enquête ministérielle' p.81

${ }^{506}$ An 36 AS 3 (Fonds de la société nationale des antiquaires de France) Registre des procès-verbaux des séances de l'académie celtique, séance du 29 fructidor an XIII (16 Sept. 1805)
} 
inspired a number of imitators, particularly amongst the ranks of the Académie celtique, in the first decades of the nineteenth century. ${ }^{507}$

Figures such as Olivet, Lecoz and La Tour d'Auvergne sought to accommodate a vision of linguistic patrimony with their membership of a French speaking nation. Affection for the mother tongue did not necessarily amount to a linguistically determined demand for political autonomy, so much as a recognition of its value as part of the heritage of the French nation, at once validating the French state and their identities as speakers of a regional language that really amounted to a historical curiosity, albeit one with a glorious past. This was less a claim for linguistic inflected regionalism or nationalism, than a construction of the local language as a feature of regional patrimony by speakers caught between, on the one hand, a metropolitan sphere of cultural and political action that valued 'francisation' at the same time as stigmatising regional speech forms, and the other local communities of linguistic practice within which speaking French was often considered a pretentious affectation. Constructing the language as a feature of linguistic patrimony enabled educated speakers to present themselves as experts on regional culture. The Académie celtique, for example, had benefited from imperial patents during its existence. In his dedication to the Empress Josephine, which appeared at the head of the first edition of the Mémoires published by the Académie, Alexandre Lenoir, curator of the Musée des monuments françaises, wrote 'c'est lorsque le plus grand souverain qu'ait eu la France, régénère entièrement ce vaste Empire, qu'il devient plus intéressant de recueillir les faits qui ont illustré ses antiques habitans'. ${ }^{508}$ After the fall of Napoleon, the Académie, rechristened at the Société des Antiquaires was eager to secure fresh royal patents from the restored Bourbon regime, and lobbied the Minister of the Interior to this effect. In the society's minutes, the Minister was said to have informed the Académie's delegation 'qu'elle faisait cas des idiomes particulier et notamment de la langue celto-bretonne dont la connaissance lui

\footnotetext{
${ }^{507}$ T.M. de la Tour d'Auvergne Origines Gauloises, celles des plus anciens peuples de l'Europe, puisées dans leur vraie source, ou Recherche sur la langue, l'origine et les antiquités des Celto-Bretons de l'Armorique, pour servir à l'histoire ancienne et moderne de ce peuple, et à celle des Français (Paris, 1797) pp.ix-x

${ }^{508} \mathrm{~A}$. Lenoir, 'Épitre dédicatoire à sa Majesté l'Impératrice et Reine' in Mémoires de l'Académie celtique' vol.1 no.1 (Paris, 1807) p.ii
} 
paraissait utile'. In response the Académie sought to buttress its credentials by sending a copy of the Grammaire celto-bretonne written by one of its members, Legonidec. ${ }^{509}$

The construction of linguistic patrimony was more than a simple alienation of regional identity into the politically neutralized sphere of tradition. It was also deployed as an attempt to legitimize claims for political concessions or social prestige, and often carried weight in governing circles. The Prud'homme patron-pêcheurs of Marseille sought to defend their privileges by leveraging their language and antiquity in just such a way. In his letter to the Coqueberts, the mayor of Marseille intimated that the city's fishermen preserved a distinct manner of speaking; 'chemise se dit camié à st. Jean, quartier des pêcheurs et l'une des plus anciens de Marseille'. ${ }^{510}$ In response, the Coqueberts had a translation of the parable in the language of Saint-Jean completed, a translation which René Merle has claimed was distinguished primarily by its use of Provençal lexis where, as we have seen, the population of Marseille frequently employed terms derived from French- 'païre' in place of 'péro' for example. ${ }^{511}$ The patron-pêcheurs cultivated this association with tradition and Provençal particularism. When the King's brother visited Marseille in 1777, the Prud'hommes played a prominent role in the festivities, attending in their distinctive black garb and addressing him in Provençal- 'notre patois' as was later written (in French) in the Prud'hommes chronicle of the encounter. ${ }^{512}$ The Prud'hommes reprised this appeal to tradition in 1790, when a group of deputies

\footnotetext{
${ }^{509}$ An 36 AS 4 (Fonds de la société nationale des antiquaires de France) Registre des procès-verbaux de I'Académie Celtique; Jean-Marie Legonnidec would go on to translate the new testament into Breton with the support of the British and Foreign Bible Society, and his grammar was influential amongst Breton cultural revivalists of the nineteenth century. See L. Dujardin-Troadec La vie et les œuvres Jean-Françoise-MarieMaurice-Agathe Le Gonidec, grammarien et lexicographe breton, 1775-1838 (Brest, 1949) ${ }^{510} \mathrm{BnF}$ NaF 5910 Antoine-lgnace Anthoine, Maire de Marseille au Ministre de l'intérieur, 9 juin 1807 ${ }^{511}$ BnF Naf 5910 Ministre de l'Intérieure au Maure de Marseille, 22 Juin 1807; R. Merle, 'ConsulatEmpire' p.338

${ }^{512}$ This argument is taken from R. Bertrand 'Le « langage patois » des « hommes de la nature " : La folklorisation des prud'hommes-pecheurs de Marseille dans le dernier tiers du XVIII siècle', L'invention du midi: représentations du sud pendant la période révolutionnaire AMIRAS/REPÈRES no. 15-20 (1987) p.15; The prud'hommes' account of the festivities marking the entry of the king's brother into Marseille can be found in the Archives départements des Bouches-du-Rhône, Marseille 250 E 12 (Fonds des prud'hommes pécheurscérémonial)
} 
on mission came to Marseille- a strategy that proved effective in preserving their legal privileges during the Revolution. ${ }^{513}$

When faced with this rhetoric of tradition, even the most zealously committed to the linguistic integration of the population could be persuaded to moderate their approach and expectation. In 1802, the prefect of the Bas-Rhin wrote that around half the population of Alsace knew some French, and that despite the opposition engendered by linguistic terrorism in the area during the Revolution, the language was gradually spreading amongst all sections of the population. ${ }^{514}$ Laumond planned to hasten the progress of French through the appointment of at least one Francophone primary school teacher to every commune, but was far from sanguine about the likely impact. The best that could be hoped for, in his estimation, was to gradually familiarise the population with the national language. The destruction of German, if possible, would take centuries because of it was so deeply ingrained in the practices and identities of the populace. This 'habitude maternelle', argued Laumond, placed language outside of the effective sphere of state action ; 'Il n'y a point de puissance humaine qui puisse empêcher un enfant de parler la langue de sa nourrice ; de père en fils la langue se transmet. Je ne sais rien qui puisse prévaloir contre cet ordre de choses' ${ }^{515}$ Recognising the difficulties faced by projects of francisation once again created value for the linguistic expertise of local bilinguals. For example, under the Consulate, three members of the conseil général of the Côtes du Nord wrote to Napoleon in support of Claude le Gorvec, who had been removed from his position as general secretary of the central administration. Le Gorvec, they argued, was enlightened, well regarded by the population, and above all enjoyed 'I'avantage de

\footnotetext{
513 Bertrand « La folklorisation des prud'hommes » p.15

514 J.-C. Laumond, Statistique du Bas-Rhin (Paris, 1802) pp.207-9 ; On linguistic terrorism in Alsace see Bell, 'Nation-building and Cultural Particularism in Eighteenth-Century France: The Case of Alsace', Eighteenth Century Studies vol.21 no.4 (1988) pp.472-490

515 Laumond, Bas-Rhin p.282
} 
connoître parfaitement l'idiôme celtique, ce qui est d'une utilité pour ainsi dire indispensable dans une départment ou un grand nombre de la population parle ce langage'.$^{516}$

These examples reveal much about the dynamics of the politics of language and linguistic practice under Napoleon. Francisation was a central tenet of Napoleonic imperialism. Bringing the benefits of the French language to the population of the Empire was considered necessary not only to facilitate the exercise of government business, but as an element in the Napoleonic improvement of society. If the ideology of Napoleonic imperialism was founded on bringing French models of governance to the rest of Europe, the French language was one of those institutions considered ripe for export. ${ }^{517}$ One result of this impulse to re-make society was the elaboration of arguments in favour of linguistic diversity. There arose a new sense of the 'mother tongue' as a significant feature of individual subjectivities. Such arguments convinced the Napoleonic regime to adopt a more pragmatic attitude towards linguistic diversity, yet it should not be understood simply as a prelude to linguistic nationalism. The idea of the mother tongue, of the embedded nature of linguistic patrimony, was a tool that speakers could exploit to locate themselves advantageously in relation both to centre and periphery. Such a route was open to speakers of France's regional languages, as much as of the standardized languages of the Empire, and did not necessarily entail claims for political autonomy. Laumond's pessimistic assessment of the prospects of francisation in Alsace reminds us that this geography did not always mirror the division between 'old' France and the annexed territories. As the second part of this thesis will demonstrate, the dynamic between francisation and the assertion of linguistic particularism as a traditional or intractable feature of local society governed the elaboration of linguistic practice within the institutions that formed a central part of Napoleon's state-building project.

\footnotetext{
${ }^{516}$ An F1 (c) III Côtes du Nord 10 (Rapports du préfet- ésprit publique) Dénouai, Armaz et Odio-Baschamps to Premier Consul, 6 vendémiaire an IX (26 sep. 1800)

517 Broers, 'La mission de Joseph-Marie Degérando' p.247 ; The Napoleonic Empire in Italy pp.1-2 ; Woolf Napoleon's Integration of Europe ch.3
} 


\section{Education, the State and Linguistic Imperialism in Nineteenth Century France}

The importance of spreading correct French to Napoleonic ambitions to improve society was clearly evident from the efforts to describe society during the period. The schoolroom was a particularly significant site for such action, although in this respect the Napoleonic regime was not an exception. During the second half of the eighteenth century, enlightened philosophes criticized the work of teaching orders such as the Jesuits for their emphasis on Latin over the national language.$^{518}$ In 1833, M. Dufilhol, one of the school inspectors of the Academy of Rennes, compiled a report on the state of primary education in the hinterland of the town of Brest. The Academy of Rennes oversaw education across most of the old duchy of Brittany, and its agents confronted the obstacle of the Breton language, still in use across much of the western half of the territory known as lower Brittany in which Brest is situated. In his report the inspector wrote candidly not only of what he considered the state's objective- the elimination of the Breton language- but of how difficult it was to obtain this goal; 'lutter contre une langue, $n$ 'est pas chose facile'. ${ }^{519}$ Dufilhol felt himself part of a greater struggle to wrap the unfamiliar sounds of the nation's language in the reluctant tongues of its Breton-speaking members, and he regarded the schools he policed as tools that might be used to such an end. However, the inspector felt obliged to sound a note of caution, if not pessimism about the results that might be expected from the area's primary schools, largely because French, far from being the sole language of instruction used in these institutions, was frequently not even the primary goal of the teaching dispensed within their walls.

The inspector's description of primary schooling in the area might have been written at any time in the preceding fifty years, and resembles comments on education in the bishopric of Léon, of which Brest was a part, made in 1790 by Pierre Riou. Writing in response to question 31 of the Abbé

\footnotetext{
$518 \mathrm{~L}$. Trenard, 'L'enseignement de la langue nationale: une réforme pédagogique, 1750-1790', Historical Reflections/Réflexions Historiques vol.7 no.2/3 (1980) pp.95-114

${ }^{519}$ AN F17 9368 (Rapports des recteurs sur l'instruction primaire) Inspections des écoles primaires de I'arrondissement de Brest (extra-muros) 1833; This report is a copy of one held in the papers of the Académie de Rennes, in the departmental archives of the Côtes du Nord, see M. McDonald, We Are Not French!: Language, Culture and Identity in Brittany (London, 1989) pp.46-7
} 
Grégoire's questionnaire on France's languages and patois- 'dans les écoles de campagne, l'enseignement se fait-il en français ? ${ }^{520}$ - Riou claimed that 'peu de campagnes ont des écoles, encore n'est-ce qu'en breton que l'on y reçoit une faible teinture plus particulière du catéchisme'.521 Forty years later the inspector of the Academy of Rennes described the situation in remarkably similar terms: 'le catéchisme est appris en breton dans toutes les écoles. On ne peut [pas] le trouver mauvais; en effet, si l'on attendait que les élèves eussent assez de français pour entendre la lettre du catéchisme, l'époque de la 1ere communion se trouverait reculée indéfiniment' ${ }^{522}$ According to both Riou and the inspector, the church dominated parish schools tended to supplement this Breton language religious instruction with Latin, rather than French. According to Riou, teaching was frequently limited to these two languages- 'rien autre chose ne s'y enseigne que la lecture bretonne et latine' ${ }^{523}$ Similarly, Dufilhol derided the failed clergymen who, having pursued studies in theology at the college in St Pol de Léon, were placed in teaching positions by the Bishop of Quimper, and who rushed their students onto the study of Latin before they had achieved even a rudimentary grasp of French. ${ }^{524}$ Students were taught to read Latin before French, to the detriment of the second language, because 'les familles et le clergé tiennent à ce que les enfans [sic] lisent à ce qu'on lire long tems [sic] en latin'. ${ }^{525}$

Comparing the report written by the inspector of the Academy of Rennes with Riou's letter to Grégoire gives a sense of religiously accented immutability surrounding educational practices in Brittany. Many teachers and clergy felt that preparing students for confirmation required the use of Breton, while teachers educated as clerics, priests in need of help in the performance of mass, and parents who perhaps saw in the church a source of employment for their sons, all tended to value Latin. As a result, the Breton classroom remained tri-lingual into the 1830 s, just as it had been before

\footnotetext{
${ }^{520}$ Gazier, Lettres à Grégoire sur les patois de France 1790-1794 (Paris, 1880) p.9

521 Ibid. p. 283

${ }^{522}$ AN F17 9368 Inspections des écoles primaires de l'arrondissement de Brest (extra-muros) 1833

523 Gazier, Lettres p.283

${ }^{524}$ AN F17 9368 Inspections des écoles primaires de l'arrondissement de Brest (extra-muros) 1833

525 Ibid.
} 
the Revolution, with French competing with Latin as the principal object of instruction. Across many of the institutions described by the inspector, the methods employed in the teaching of French seem to have remained largely unchanged in the decades following the Revolution. The inspector approvingly described the use of a book entitled Colloque français-breton, placed alongside the catechism of the diocese of Léon in Breton in a list of the most frequently used books in the schools surrounding Brest. First published in 1626, the Colloque went through 70 editions up to $1915 .{ }^{526}$ The earliest editions of the book contained a short dictionary and a number of dialogues in French, Breton and Latin, the third language being removed in later versions. In class, the pupils would be tasked with learning a certain number of French words and their Breton equivalents from the book every day, with the teacher subsequently requiring them to translate these words between the two languages from memory. ${ }^{527}$ The book and the associated 'translation method' remained common until the last decades of the nineteenth century, ${ }^{528}$ as claimed by the editor in the preface to the 1863 edition; 'il fait la base de l'instruction des petites écoles des villes et des campagnes' ${ }^{529}$

The persistence of old teaching practices, as well as the emphasis on Breton and Latin instruction, raises important questions about the role of education in spreading the French language during the period. Figures like Dufilhol were self-consciously engaged in a project of linguistic imperialism. It will be argued that those charged with administering the education system, especially following the Revolution, saw teaching French to the non-Francophone populations within the borders of the French state as a central part of their mission. This was also a period in which the system they ran witnessed substantial gains. Literacy increased from around $40 \%$ in 1800 to around

\footnotetext{
${ }^{526}$ P. Trepos, 'Le Catholicon de Jehan Lagadeuc, pour son cinquième centenaire', Annales de Bretagne Vol.71 no.4 (1964) p.501

${ }^{527}$ AN F17 9368Inspections des écoles primaires de l'arrondissement de Brest (extra-muros) 1833

${ }^{528}$ When Irénée Carré propagated the 'direct method' or 'méthode maternelle' in Brittany, a method that purported to replicate natural language acquisition, for example through the use of realia- everyday objects that allowed the teacher to demonstrate vocabulary to pupils without recourse to Breton. See L. Puren 'Pédagogie, idéologie et politique linguistique. L'exemple de la Méthode Carré appliqué à la francisation de la Bretagne à la fin du XIXe siècle', Glottopol- Revue de sociolinguistique en ligne No.1 (2003) p.33 http://www.univ-rouen.fr/dyalang/glottopol/telecharger/numero 1/gpl1 03puren.pdf Accessed 28/12/2012; McDonald, We Are Not French! pp. 46-50

${ }^{529}$ Colloque français et breton, ou nouveau vocabulaire (Saint-Brieuc, 1863)
} 
$50 \%$ at the start of the 1830 s, while schools were brought under the control of a substantial national bureaucracy with the establishment of the Imperial University in $1808 .{ }^{530}$ Yet the primary schools of Brittany continued to reflect the demands and priorities of the communities in which they operated, rather than the volition of the state. This meant providing a religious education through the medium of Breton, and an apprenticeship in Latin for those who might later seek a career in the church, not teaching them French.

As this chapter will show, the schools of Brittany were not exceptional in this regard. Responses collected from other parts of France by the Abbé Grégoire demonstrate how Latin and other minority languages were widely used in France's classrooms in the early 1790s. The efforts of the state to transform this situation and make education a vehicle for the French language manifested themselves in a series of laws and attempted reforms. They were also reflected in the many inspection reports from both the Empire and Restoration periods, which demonstrate how the desire to spread the French language throughout the population of France was consistently held even under politically very different regimes. However, the basic problems these reports reveal, most commonly the lack of qualified teachers, point to a more fundamental conclusion that will be displayed with the greatest clarity in the context of an examination of the teachers of the AlpesMaritimes- the state lacked the power to make educational institutions the instruments of linguistic imperialism it desired them to be. Faced with such difficulties, many administrators eventually followed the Coqueberts, accepting the limits of state action. Moreover, the patterns of French language tuition, analysed in detail for the Alpes-Maritimes, demonstrate that the schoolroom should not be considered simply as a mechanism for the imposition of centralized culture, but also reflected the needs of local society. Reflecting on the distinction between ' $\mathrm{H}$ ' and ' $\mathrm{L}$ ' varieties that emerged from the Coqueberts' enquiry, French was embedded in the schoolrooms of areas where the language dominated literate culture, and where it was of use to members of local society.

${ }^{530}$ R. Grevet, L'avénement de l'école contemporaine en France: 1789-1835 (Lille, 2001) p.258 


\section{Education and Language at the end of the Old Regime}

As Riou's response to the linguistic survey of the Abbé Grégoire shows, the classrooms of France as they were found by the Revolutionaries were often anything but a vehicle for the proliferation of French. Amongst the forty three questions that comprised Grégoire's survey, seven related directly to education. In addition to question 31 on whether French was taught in the area's schools, Grégoire wanted to know whether each village had its own schoolteacher (question 32), what was taught in these schools beyond reading, writing, arithmetic and the catechism (question 33), whether these schools were rigorously monitored by the clergy (question 34) and finally what reading materials were available to them (questions $31,35-7$ ). ${ }^{531}$ The majority of the responses to Grégoire's survey, received between 1790 and 1792 and held in the Bibliothèque Port-Royal in Paris, have been reprinted, either by Augustin Gazier in 1880, or as part of the copious appendices of the 2002 edition of Michel de Certeau, Dominique Julia and Jacques Revel's book on Grégoire's survey. ${ }^{532}$ This makes them an unrivalled source, in terms of accessibility and geographical coverage, when it comes to an examination of the fractured and diverse character of both educational practice and provision in the teaching of French at the start of the Revolution.

While this material presents few straightforward conclusions, some broad distinctions do emerge, even if each one must be qualified with exceptions. Perhaps the most prominent was between the northern, Langue d'oil speaking territories and the Langue d'oc speaking areas of the south. According to Grégoire's respondents, schooling in the North tended to take place almost exclusively in French. The response from the mayor of Saint-Claude in the Jura stated simply that schooling took place 'en français', even though he observed that many villagers still spoke patois. ${ }^{533}$ However, this did not prevent concerns about the quality of French that might be taught within schools, such as those expressed of the schools in Poitou by the Abbe Perreau, who claimed that despite French being the only language used in the area, 'I'enseignement se fait en français, mais

\footnotetext{
${ }^{531}$ Certeau et. al., Une politique de la langue pp.15-6

532 Ibid., pp.183-273

${ }^{533}$ Gazier, Lettres pp. 200, 205
} 
mauvais français'. ${ }^{534}$ This did not make all classrooms in the north linguistic monocultures. In Burgundy, for example, it was claimed that 'l'enseignement se fait en français, et le langage ordinaire en patois', ${ }^{535}$ highlighting how even where French was the language of instruction the speech of pupils and even teachers was not always as rigorously policed as later educationalists such as Dufilhol advocated.

According to respondents from the south of France, French was generally an aim of the education provided in schools, although those writing from the south were often pessimistic about the impact such instruction had on students' knowledge of the language. Just as in the north, French was not necessarily the sole language to be spoken in the classroom, even where it was the object of the lesson. As the members of the Société des amis de la constitution de Carcassonne wrote, 'on y lit des livres uniformes, mais trop relevés; d'ailleurs, les enfants et les maîtres parlent patois..$^{536}$ Pessimism about the contribution schools might make arose as much from the language spoken outside classrooms as within it. Thus the response from Lyon, located within what is now regarded as the territory of the Francoprovençal language, lamented that 'l'instruction se fait en François; mais, $[\ldots]$ l'obligation où sont les enfants de parler toujours avec des gens qui ne parlent que le patois rend cette instruction inutile pour la langue' ${ }^{537}$ Unlike most respondents from the south, the Société des Amis de la constitution de Maringues in the Auvergne implied that little effort was made to teach French to rural dwellers in the area's schools: 'les paysans n'apprennent qu'un catéchisme, qu'ils n'entendraient point quand ils parleraient français'. ${ }^{538}$ This circumscribed curriculum was perhaps all that might be expected given the disparaging characterisation of the area's teachers by the Société, which claimed that only one in twenty villages had 'un maître qui sait à peine épeler,' a

\footnotetext{
${ }^{534}$ While this response was listed as anonymous by Gazier, Certeau et. al., identify Perreau as the author. Gazier, Lettres p.278; Certeau et. al., Une politique de la langue p.187

535 Gazier, Lettres p.226

536 Ibid., p. 20

537 Certeau et. al., Une politique de la langue p.243

538 Gazier, Lettres p.164
} 
meagre provision supplemented only by 'le curé qui fait répéter les mots du catéchisme à ses paroissiens perroquets..$^{539}$

However, the obstacle to the effective teaching of French in schools most frequently cited by respondents from the south was the widespread teaching of Latin. Echoing the importance of Latin to education in Brittany, as described by Pierre Riou, the Amis de la constitution d'Auch in the Gers claimed that 'l'enseignement ne se fait ni en patois, ni en français. Les curés, qui en sont chargés presque partout [...] se bornent à enseigner à un ou à deux à servir la messe' ${ }^{540}$ The response drafted by the Amis de la constitution d'Agen described a similar situation, whereby teachers, predominantly the local curé, taught both French and Latin to their pupils, but frequently began with the latter. As a result, 'l'éducation se réduit presque, dans nos campagnes, à rendre les élèves capables de pouvoir, les jours de fête et dimanches, aider leurs pasteurs à chanter les louanges de Dieu dans une langue qu'ils n'entendent pas'. ${ }^{541}$ An identical situation was described by François Chabot, a former Capucin from Rodez, and Pierre Bernadau, a lawyer from Bordeaux. ${ }^{542}$ Of course, the emphasis placed on teaching and learning Latin was not simply a function of the local clergy's need for assistants at religious ceremonies, but doubtless reflected the priorities of those being taught and their parents. While some villages had endowments left by wealthy individuals to fund schools for the poor, and others might oblige teachers to allow poor students to study for free, their fees subsidised by those paid by the better off, the majority of students had to pay for lessons. As a result, educators had to meet, to some extent at least, the demands of parents and learning Latin was frequently one such demand. For some this no doubt arose from the enduring prestige of Latin as a language of learning. ${ }^{543}$ However, for the majority a desire to have their children learn Latin stemmed from the language's importance in Catholic religious practice. As François Chabot observed of the predilection of the rural dwellers of the Lot and Garonne for the language ; 'les paysans les

\footnotetext{
539 Gazier, Lettres p.164

540 lbid., p.95

541 lbid., p.119

542 Ibid., p.60; Certeau et. al Une politique de la langue p.202

${ }^{543}$ P. Burke, Languages and Communities in Early Modern France (Cambridge, 2004) p.44
} 
plus cossus se ruinaient quelquefois pour faire apprendre le Latin à leurs enfants, afin d'en faire des prêtres' ${ }^{544}$

This pattern of Latin and spoken patois squeezing out French teaching was not entirely ubiquitous across those areas of France where languages other than French or varieties of the Langues d'oills were spoken. In the department of the Nord, where Flemish was spoken in the north east of the department, the response from St. Omer simply observed that lessons took place in French, except for in the Flemish speaking schools, with no mention of Latin. ${ }^{545}$ Similar information emanated from Bourgues, where there were also 'quelques écoles françaises, meme aux villages les plus considerables', although the efficacy of such institutions was said to have been negligible, since students found little use for the language outside the classroom. ${ }^{546}$ Elsewhere in the south of France respondents could lament the trivial impact of schools in spreading French without viewing Latin as a serious obstacle. The Société des amis de la constitution de Carcassonne, having related the tendency of both students and teachers to talk in patois, went on to explain that education scarcely went beyond reading, writing, arithmetic and the catechism. According to the report, only 'dans les gros lieux il y a des maîtres de Latin', thereby inverting the testimony of many other respondents from the south who saw this language as an encumbrance for the most humble of country schools. ${ }^{547}$

As such comments suggest, the sense that the prevalence of Latin within France's classrooms inhibited the teaching of French overlay, if only imperfectly, a more fundamental distinction between urban and rural space. This was a division that likely suggested itself to respondents through the question on schooling, which was concerned explicitly with 'les écoles de campagne' and followed with questions on the reading habits and superstitions of the 'gens de la

\footnotetext{
544 Gazier, Lettres p.60

545 Ibid., pp.258-9

${ }^{546}$ Certeau et. al., Une Politique de la langue p.261

547 Gazier Lettres p.20
} 
campagne' ${ }^{548}$ As a result the countryside, and in particular the rural school, was designated by the questionnaire itself as particularly worthy of attention, as a key site in any effort to bring enlightenment and the French language to the population of France. ${ }^{549}$ Grégoire's respondents duly characterised rural space in opposition to urban space, as a zone where little or even no French was spoken, where teachers were scarce and schools dominated by the frequently less than benevolent gaze of the local clergy. The response from Agen, for example, blamed the reduction of education to a smattering of Latin on the small size of rural villages. These villages, unable to support a schoolmaster, were forced to rely on the clergy for instruction. ${ }^{550}$ As Pierre Bernadau remarked of the education in the territory surrounding Bordeaux, 'l'enseignement des campagnes est assez nul dans ce district. [...] II n'y a que les gros bourgs qui soient pourvus de maîtres d'école [...] on ne trouve des maîtres d'écriture que dans nos petites villes; là l'éducation est mieux soignée, mais plus dispendieuse. ${ }^{551}$ Bernadeau's description revealed a more variegated understanding of the distinctions between types of space than the simple opposition of 'rural' and 'urban'. Bourgs were distinct from the smaller villages that surrounded them. They were home not only to the parish church and other services but, where they existed, professional teachers chosen by the village council. The presence of a designated schoolteacher would not necessarily have marked a departure in the kind of education provided. Most would likely have been ecclesiastics themselves, or at least appointed under the auspices of the local curé, who served on the municipal council, although they would most likely have had more time to devote to education. Inhabitants of the surrounding villages thus had to overcome the obstacle of travel into the local bourg to attend school regularly, whether run by the local curé or a schoolteacher.

The school at the end of the Ancien Régime was, therefore, far from a homogenous institution. Not simply the accessibility of education, but the linguistic ecology of the classroom could vary drastically

\footnotetext{
548 Gazier Lettres p.9

${ }^{549}$ Certeau et. al., Une politique de la langue p.20

550 Gazier, Lettres p.119

${ }^{551}$ /bid., pp.141-2
} 
according to where a school was found. As testimony from Brittany, Flanders and the South of France demonstrate, the classrooms found in parts of France where French was not the mother tongue of large swathes of the population were, perhaps unsurprisingly, much less likely to have large amounts of French spoken within them. The enduring importance of Latin in Catholic religious practice could result in a situation where this language and the local tongue dominated educational settings, to the detriment of French. This was a distinction overlain with divisions between urban and rural areas. Grégoire's respondents made clear that French education was more likely to be available to urban dwellers and that the less densely populated an area, the lower the likelihood of a dedicated teacher working in French.

\section{Educational Reform and Language from Revolution to Restoration}

Following the political upheavals of 1789 , the profound disparities that characterised the French primary school in general, and the teaching of the French language in particular, became an object of concern for successive regimes. The Revolution brought with it a multitude of educational projects intended to create an enlightened citizenry that might buttress the new civic order. ${ }^{552}$ Henceforth the school was to be a national institution, and education a tool for the creation of Frenchmen. ${ }^{553}$ This meant that the classroom would have to become a foothold for the French language, and the state would have to take a more active role in ensuring both provision and quality.

The desire to extend the state into primary school provision was manifested in legislation on the $29^{\text {th }}$ Frimaire year II (19 1 th $\left.D e c e m b e r ~ 1793\right)$ with the passage of the Loi Bouquier. This law made education obligatory and free, with teachers salaried by the state. A little over a month later, on the $5^{\text {th }}$ Pluviôse $\left(24^{\text {th }}\right.$ January), Barère made his now famous speech to the convention, and the decree that followed explicitly mobilised schools for the purposes of spreading the French language. Barère's approach to the issue of France's linguistic diversity can be summed up usefully in one frequently cited passage of his speech- that 'le federalism et la superstition parlent bas-breton;

\footnotetext{
${ }^{552}$ R.R., Palmer The Improvement of Humanity: Education and the French Revolution (Guildford, 1985)

${ }^{553}$ Bell, Cult of the Nation pp. 1-3
} 
L'émigration et la haine de la république parlent l'allemand; la contre-revolution parle l'italien et le fanatisme parle le basque ${ }^{\prime 554}$ Barère then proposed a measure requiring that, within ten days, a teacher of the French language would be established in every Breton speaking commune of the departments of Morbihan, Finistère, Côtes-du-Nord, lle et Villaine and the Loire-Inférieure, in every German speaking commune of the departments of Alsace and Lorraine, in every Italian speaking commune of the Alpes Maritimes and every Basque speaking commune of the Basses-Pyrénées. ${ }^{555}$ Not only was spreading the French language now seen as crucial to the survival of the Republic, it was within the walls of the classroom that the population was to be transformed into French speaking citizens.

The establishment of French schools across such a large number of communes proved wildly overambitious, as did the provisions of the loi Bouquier. In practice the reforms were implemented in a piecemeal fashion, hampered by political conflict and a lack of both money and suitable teachers, meaning they had little impact across France as a whole despite some progress in areas like Alsace. ${ }^{556}$ Following the fall of Robespierre, education continued to be viewed as a sphere in which the state action should facilitate the spread of French. The loi Lakanal of the $27^{\text {th }}$ Brumaire year III $\left(17^{\text {th }}\right.$ November 1794$)$ sought to establish a school for every thousand habitants, free to pupils but not obligatory. The law also required not only that schools taught French, but that they used it as the primary language of instruction, for the first time regulating the use of languages within the classroom on a national scale. The law's author, Joseph Lakanal, was dispatched on mission to the south west of France shortly after its publication, charged with ensuring its execution. Perhaps unsurprisingly, the school regulations published in the area tended to mirror the text of the law, as was the case with those agreed upon for the primary schools of the district of Agen, which

\footnotetext{
${ }^{554}$ B. Barère, 'Rapport du comité de salut public sur les Idiomes', Certeau et. al., Une Politique de la Langue p.326

555 Ibid., pp.329-330

${ }^{556}$ H.C. Bernard, Education and the French Revolution (London, 1969) p.132
} 
stipulated that 'les leçons seront toujours données en langue française; mais l'instruction pourra quelquefois employer l'idiome local, comme moyen auxiliaire, ou de comparaison' ${ }^{557}$

The impossibility of fulfilling the provisions of these pieces of legislation was recognised less than a year after the passage of the loi Lakanal, when the loi Daunou of the $3^{\text {rd }}$ Brumaire year IV (25 $5^{\text {th }}$ October 1795$)$ ended free schooling. However, while individual communes and parents, rather than the state, now had to meet teacher's salaries this did not mean the total withdrawal of the state from primary education or that efforts to spread French were forgotten, at least in principle. The Ioi Daunou established local juries of public education to oversee schools. These juries were initially established on the level of the district, and despite questions surrounding their efficacy they survived the fall of Napoleon, being shifted to department level and then finally down to the canton after the restoration. ${ }^{558} \mathrm{~A}$ central function of such juries was to examine the capacity of teachers, including their ability to teach French, with prefects enjoying the power to approve the selection of teachers by municipal councils based on the recommendations of such juries. The state's role in the oversight, if not provision, of primary education was secured by the establishment of the Imperial University in 1808, which also saw the creation of a new centralised bureaucracy dedicated to the administration of the education system. ${ }^{559}$ The University was split into a series of smaller academies, each one responsible for education within the jurisdiction of a different court of appeal, and each one with school inspectors tasked with visiting primary schools in the area. All teachers were now obliged to become members of the university; in theory at least, no schools could be opened without the authorisation of the Grand Master of the University in Paris. The establishment of the University also brought about new proscriptions on the teaching of languages. Perhaps mindful of territories newly annexed to France during the revolution, where the great majority of

\footnotetext{
${ }^{557}$ AN F17 1344/35 (Pièces adressées ou renvoyées au comité d'instruction publique- papiers de Joseph Lakanal) Règlement provisoire proposé par le juri d'instruction à l'administration du district d'Agen pour les écoles primaire de ce district, arête par le conseil du district, 15 Ventôse an III (5 Mar. 1795) ${ }^{558}$ R. Gildea, Education in Provincial France, 1800-1914 (Oxford, 1983) p.30

559 The case for the significance of the period to the development of modern educational institutions in France is made in Grevet, l'école contemporaine pp.80-1
} 
literate culture took place in a language other than French, secondary schools and Lycées were now explicitly required to teach French. Furthermore, all teachers providing tuition in Latin were obliged to pay the University a twentieth of the fees received from their students, in theory making the language less attractive to rural schoolmasters and parents, encouraging a focus on reading, writing and arithmetic, as well as French. The University, like the juries of instruction, survived into the restoration, and as will be seen, the men who staffed it remained loyal to the notion that spreading the French language amongst the non-Francophone populations that came under their authority was one of the basic functions of the school.

\section{Italian in the Alpes-Maritimes- linguistic unification and education under Napoleon}

As one of the areas singled out to receive French teachers by Bertrand Barère in the year II (1794), the Alpes-Maritimes stood out as a particular locus of government action. The old country of Nice, from which the department was formed, was part of the Kingdom of Sardinia until the Revolution, only becoming part of France when it was annexed by French troops in 1792. Italian therefore formed an important part of the area's literate culture, and a spur to French administrators wary of linguistic separatism and its political ramifications.

However, despite the attentions of figures like Bertrand Barère, Italian remained widely used in the schools of the department into the period of the Consulate, particularly those situated in remoter, less populous areas. On the $7^{\text {th }}$ Thermidor year XI (27 July 1803$)$, a few months after his appointment as prefect, Marc Joseph de Gratet Dubouchage circulated a questionnaire on the department's schools. Dubouchage included questions on the number of teachers and students, how the teachers were paid, and crucially on 'la nature des choses qui sont enseignées dans ces écoles, et dans qu'elle langue se fait l'enseignement'.${ }^{560}$ The responses conserved in the departmental archives give a total of 62 teachers, almost certainly an underestimate since replies from some of the department's communes, notably Nice, are not present. Breaking these figures

${ }^{560}$ AdAM CE 1 T 1 (Organisation générale de l'instruction publique) Questionnaire sur les écoles du département des Alpes-Maritimes , 7 thermidor an XI (26 Jul. 1803) 
down by the language of instruction, as in Table 3, shows that of the 62 teachers identified by mayors in their responses, 22 taught French, 24 Italian and 14 both languages, with 2 teachers for

Table 3: Alpes-Maritimes- Teachers by Languages Taught, Thermidor-Fructidor year XI (July-August 1803)

\begin{tabular}{|l|l|l|l|l|l|}
\hline $\begin{array}{l}\text { Languages(s) } \\
\text { Taught }\end{array}$ & French & Italian & $\begin{array}{l}\text { French and } \\
\text { Italian }\end{array}$ & Unknown & Total \\
\hline $\begin{array}{l}\text { Number of } \\
\text { Teachers (\%) }\end{array}$ & $22(35.5)$ & $24(38.7)$ & $14(22.6)$ & $2(3.2)$ & 62 \\
\hline
\end{tabular}

whom no information on language was presented. These figures reveal just how prevalent Italian remained in the department's schools. Well over a third-38.7\%- taught no French whatsoever, while Italian was taught in nearly two thirds- $61.3 \%$ - of classrooms. Furthermore, these figures likely exaggerate the extent of French tuition in the department's schools. Many of the schools listed as bilingual in fact focused on Italian, frequently with the addition of Latin. Jacques and Antoine Granella, both priests trained in Piedmont employed as teachers in La Brigue in the Year XI were examples of just such a practice. The commune's mayor listed both as teachers of French and Italian, along with Latin, but added that 'la langue française est cependant la plus negligée'. ${ }^{561}$ While over half of teachers may have taught French, this did not necessarily mean that significant classroom time was spent on the language. Even where a French teacher existed, the language was generally only taught at the behest of parents. Thus in addition to Italian and Latin, Charles Bacelli, a priest and teacher in the commune of Peille, taught French 'à ceux qui désirent l'apprendre'. ${ }^{562}$ In many parts of the department this may have been a minority, to judge by the comments of the Mayor of La Brigue, who claimed that 'les habitans [sic] de ce pays liés par la force de l'habitude à la langue Italienne qui leur est presque naturelle regardent la française comme inutile'. ${ }^{563}$

\footnotetext{
${ }^{561}$ AdAM CE 1 T 1 Maire de La Brigue au sous-préfet de Monaco, 20 thermidor an XI (8 Aug. 1803)

562 AdAM CE 1 T 1 Maire de Peille au préfet des Alpes-Maritimes, 19 thermidor an XI (7 Aug. 1803)

${ }^{563}$ AdAM CE 1 T 1 Maire de La Brigue au sous-préfet de Monaco, 20 thermidor an XI (8 Aug. 1803)
} 
Not only did Italian remain the dominant language of instruction in many of the department's classrooms a decade after the arrival of French troops, it is difficult to discern any significant increase in the teaching of French once the linguistic geography of the area before it became part of France is considered. Figure 9 shows the geographic spread of French language teaching according to the responses to Dubouchage's survey. Plotting the information in this way reveals a distinct geography. In the Year XI, communes where teaching was confined to French were clustered in the North West of the Department, those where education took place in both French and Italian were located predominantly on the more populous littoral, home to the larger urban centres like Nice and Monaco. Meanwhile, communes where education was restricted to Italian were generally found in the more rugged and sparsely populated terrain of the centre of the department. There was a striking concordance between the distribution of French language schools and the border between French and Italian languages shown on the linguistic map drawn up at the behest of the Minister of the Interior in 1806 (Figure 10). ${ }^{564}$ According to the sub-prefect of PugetTheniers, this linguistic division was an old one. Many of the communes of this area had been part of France, but were ceded to the Sardinian crown by treaties signed in 1713 and 1760 . When these communities became part of the county of Nice, Charles-Emmanuel II permitted them the continued use of French for the drafting of legal documents, ${ }^{565}$ a practice that endured until the annexation by France. The rest of the territory identified as French speaking by the sub-prefect had belonged to the old diocese of Glandèves, where 'le français étoit [sic] en usage dans la société, et les études se faisoient [sic] en cette langue'. ${ }^{566}$ As a result it seems likely that the cluster of teachers working solely in French in the North West of the department predated the area's annexation to France.

\footnotetext{
${ }^{564}$ BnF Naf 5913 Carte du département des Alpes-Maritimes

565 The king's letter granting this privilege has been reproduced in J.-B. Lacroix (ed.), Trésors d'archives, Mille ans d'histoire (Nice, 2005) p.229 A report detailing the lack of Italian speaking legal officials and the consequent necessity of permitting the use of French can be found in AdAM Nizza Mazzo add. 005 Memoria per l'amministrazione della giustizia nelle terre della provincia, e per lo stabilimento della prefettura nel luogo di Guillaume, 1761

${ }^{566}$ AdAM CE 4 T 1 (Fonds de la préfecture, affaires culturelle) Sous-préfet de Puget-Theniers au Préfet des Alpes Maritimes, 16 Jul. 1806
} 
French language teaching in this area was not the result of the transfer of sovereignty to France, or the efforts of French administrators, but followed older patterns of language education.

It also seems likely that the presence of French language instruction in the department's coastal areas was not entirely an innovation brought about by French government. Even in these parts of the department, designated as Italian speaking by the linguistic map compiled in 1806, French was not entirely absent. This much can be seen from the French language printed and manuscript material collected by Joseph Levrot in the 1930s in an attempt to prove that the use of the French language in Nice predated the city's annexation to France. ${ }^{567}$ Most of the teachers working in this area do not appear to have been imports brought with the French. For example, Jean Baptiste Bosio, a bilingual teacher from Monaco was said to have exercised the same position under the Ancien Régime, ${ }^{568}$ while Dominique Rossetto, a priest teaching both French and Italian in La Turbie was noted as having pursued his studies in Italy. ${ }^{569}$ French language teaching was not necessarily introduced into the area by the French state.

The responses to his questionnaire of the $7^{\text {th }}$ Thermidor year XI prompted Dubouchage to take action. On the $30^{\text {th }}$ of the same month, before the final responses had even reached the prefecture, he despatched a circular to the sub-prefects and mayors of the department expressing his unease that the information he had gathered showed that most of the department's primary school taught Italian and Latin, while ignoring French. Dubouchage made clear his position on the teaching of languages other than French- 'la langue française est la langue du gouvernement, et doit être la langue du pays'. To this end the prefect stipulated that 'aucun instituteur ne soit salarié, à moins qu'il ne justifie par-devant les Jurys d'instruction, qu'il enseigne le Français [...]l'enseignement des langues étrangères ne saurait être aux frais du public il appartient aux familles aisées de le

\footnotetext{
${ }^{567}$ AdAM $6 \mathrm{~J} 3$ (Fonds Joseph Levrot- usage de la langue française à Nice)

${ }^{568}$ AdAM CE 1 T 1 Maire de Monaco au préfet des Alpes-Maritimes, 5 fructidor an XI (23 Aug. 1803)

${ }^{569}$ AdAM CE 1 T 1 Maire de La Turbie au préfet des Alpes-Maritimes, 23 Thermidor an XI (11 Aug. 1803)
} 
procurer' ${ }^{570}$ The public expenses to which Dubouchage referred were the stipends and lodgings provided to many of the department's teachers from communal funds and property. Dubouchage was not the only Napoleonic administrator who took action to spread French through the primary school system. Laumond, the prefect of the Bas Rhin, sought to establish a French school teaching in every German-speaking commune, although he was pessimistic about the likely impact of his measures. ${ }^{571}$ In the Academy of Liège, a large comprehensive survey of the language of primary school instruction in the Flemish-speaking parts of the region was carried out after the creation of the Imperial University. Only those teachers capable of working in French were granted full authorisation. Those willing and able to learn the language were given temporary dispensation to continue teaching. Some teachers, such as Jean Morhaye in the arrondissement of Maastricht, knew French but obstinately refused to teach it, and were thus barred from the profession. ${ }^{572}$

The prefect's circular did meet with some immediate success, though perhaps not of the enduring and comprehensive character he might have hoped. This can be seen from the dossiers of correspondence relating to the nomination, payment and regulation of each commune's schools found in the papers of the prefecture in the departmental archives. On the $6^{\text {th }}$ Fructidor year XI $\left(24^{\text {th }}\right.$ August 1803), in response to the circular of the $30^{\text {th }}$ Thermidor, the municipal council of the commune of Peillon appointed Pierre Raimondi as communal schoolteacher, to take affect only after he had been assessed capable of teaching French by the local jury $d^{\prime}$ instruction. ${ }^{573}$ In Brumaire year XII (1803) the nomination of André Blanqui as teacher for the commune of Roure was justified by his ability to fulfil the requirements of the circular, and his nomination would only be confirmed after satisfying the jury d'instruction that he could teach French. ${ }^{574}$ However, despite having expressly required the teaching of French in the primary schools of the Alpes-Maritimes, the prefect continued

\footnotetext{
${ }^{570}$ AdAM CE 1 T 4 (Enseignement primaire) Circulaire préfectorale du 30 thermidor an XI (18 Aug. 1803)

${ }^{571}$ Laumond Bas-Rhin pp.207-9

${ }^{572}$ AN F17 10171 (Académie de Liège- Instruction Primaire) 1811-1813- Liège, instituteurs primaires

${ }^{573}$ AdAM CE 1 T 6 (Enseignement primaire- situation dans les écoles) Extrait des déliberations du conseil municipal de Peillon, 6 Fructidor an XI (24 Aug. 1803)

${ }^{574}$ AdAM CE 1 T 6 Arrêté du maire de Roure, 10 Brumaire an X (1 Nov. 1801)
} 
to receive letters denouncing teachers for working in Italian. Thus Pierre Boccaron of Saint Martin du Var wrote to the prefect in Floréal of year XIII (1805), complaining that 'Monsieur Victor Baudoin prêtre [...] se permet de continuer à montrer la langue italienne et latine et fouler aux pieds les ordres que M. le Maire peut y avoir donnés'..$^{575}$

That the prefect, despite his efforts, was unable to impose French upon the totality of classrooms in the department is evident from the information collected for a second survey of the area's teachers in 1809. This time the mayors were required to complete a table, providing information such as the name and age of any teachers in the commune, their salaries and number of students, and finally any other observations about the teacher or school. ${ }^{576}$ These observations sometimes included information about the language taught by specific teachers, although since the mayors were not prompted to give such information the information they provided was inevitably far sparser than for the year XI. It has, however, been possible to supplement this information with sources found elsewhere in the departmental archives, either from the correspondence on the nomination and conduct of teachers, ${ }^{577}$ the survey carried out in the year $\mathrm{XI}$, and two essays on primary schools, one concerning Nice dated $1807,,^{578}$ and one concerning the arrondissement of San Remo dated $1809 .{ }^{579}$ The use of such supplementary material obviously requires caution. Given the pressure exerted by the prefect, it has been considered safe to assume that a teacher working in French earlier in the period continued to do so in 1809 , but that it cannot be assumed a teacher working solely in Italian would not subsequently have begun teaching in French. Similarly, for information provided after 1809 , it is presumed that a teacher identified as teaching only Italian would not have dropped French after this point, but that teachers working in French or French and

\footnotetext{
${ }^{575}$ AdAM CE 1 T 4 Pierre Boccaron au préfet des Alpes-Maritimes 18 floréal an XIII (9 Nov. 1804)

${ }^{576}$ The replies are to be found in ADAM CE 1 T 4 (Enseignement primaire)

${ }^{577}$ AdA-M CE 1 T 5 (Enseignement primaire- situation dans les écoles) Aspremont- Lucèram; AdAM CE 1 T 6 (Enseignement primaire- situation dans les écoles) Malaussène- Sospol ; AdAM CE 1 T 7(Enseignement primaire- situation dans les écoles) Tend- Ventimiglia

578 AdAM CE 1 T 4 Rapport sur l'instruction publique en la ville de Nice, 1807

${ }^{579}$ AdAM CE 1 T 4 Rapport général sur les écoles de l'arrondissement de San Remo
} 
Table 4: Alpes-Maritimes- Teachers by Languages Taught, 1809

\begin{tabular}{|l|l|l|l|l|l|}
\hline & \multicolumn{5}{|c|}{ Number of teachers } \\
\hline Arrondissement & French & Italian & $\begin{array}{l}\text { French and } \\
\text { Italian }\end{array}$ & Unknown & Total \\
\hline Nice & 9 & 6 & 12 & 45 & 72 \\
\hline San Remo & 5 & 8 & 1 & 54 & 68 \\
\hline Puget Theniers & 2 & 1 & 2 & 30 & 35 \\
\hline Total & 16 & 15 & 15 & 129 & 176 \\
\hline
\end{tabular}

Italian may have altered their practices to accommodate the demands of the state after 1809 . The results of this operation are given in Table 4. These numbers are too uncertain to draw conclusions about the evolution of the proportion of educators teaching in French- there are simply too many unknowns. Moreover, such a comparison would be skewed by the addition of the arrondissement of San Remo to the department, which was almost entirely Italian speaking. Fifteen of the teachers surveyed continued to work exclusively in Italian, while another fifteen taught both Italian and French. Even excluding the Italianate arrondissement of San Remo, seven teachers continued to work in Italian only. Linguistic practice was not changed by administrative diktat.

The relative inefficacy of efforts to spread French in the department was in part due to the unreliability of the juries of education charged with examining primary school teachers and distributing certificates of capacity. This unreliability was demonstrated when, in August of 1810, Dubouchage circulated a letter to his sub-prefects asking for information on the linguistic capacity of the department's teachers. ${ }^{580}$ In his response the sub-prefect of Puget-Theniers claimed he had often been shocked by the lack of knowledge many of the arrondissement's teachers displayed on the very subjects they were meant to be teaching. This was despite their possession of certificates of capacity delivered by the arrondissement's jury d'instruction, composed of the local curé, another local member of the clergy and a doctor. Dismayed by this state of affairs, the sub-prefect confronted one of the members of the jury:

580 AdAM CE 1 T 2 (Organisation générale de l'instruction publique) Préfet des Alpes-Maritimes aux Souspréfets 20 Aug. 1810 
Ayant fait des reproches à quelque membre du jury sur la facilité d'expédier des certificats de capacité à des hommes ineptes, il m'a été répondu que s'il falloit [sic] user de rigueur, il n'existeroit [sic] aucun Instituteur primaire dans l'arrondt. [sic] et j'ai compris que pourvu que l'impétrant eût la qualité de prêtre, et qu'il sût balbutier quelques mots françois, [sic] on n'exigeoit [sic] pas davantage. ${ }^{581}$

If the standards demanded by the juries were deemed insufficiently rigorous by the sub-prefect, it should be noted that they were further weakened by the possibility of negotiating a period of grace, in which a teacher could exercise despite not having yet fulfilled the requirements of the examination. In the year XII Jean-Baptiste Priori was authorised by the jury d'instruction to teach in the commune of Lucéram, 'à la condition expresse qu'il fera ses efforts pour se perfectionner dans la langue française, qu'il n'enseignera qu'en français, et qu'il cesser ses fonctions si dans l'inspection qui aura lieu dans le courant de cette année, la langue française n'est pas enseignée' ${ }^{582}$ Several years later, in January 1812, Priori was the subject of a petition by 5 of the members of the commune's municipal council who demanded Priori's replacement, in part, on the grounds that he was not teaching French to his students. ${ }^{583}$ The Abbé Delerbra had been authorised in 1805 on the same conditions, but despite having failed to fulfil them he was only removed in $1812 .{ }^{584}$

The juries of instruction were not entirely irrelevant, and they did on occasion fail candidates. This was exactly what happened to François Benet who was examined in the year IX (1801), with the members of the jury concluding that 'le Cen. Benet n'ayant aucune connaissance [...] sur la langue française [...] a été reconnu incapable de remplir le place d'instituteur primaire'. ${ }^{585}$ However, it often proved too easy for teachers to avoid the examinations that were supposed to be conducted by the jury on all new teachers before they took up their posts. Jacques Robion of the commune of Roure, for example, was listed in the survey of the year XI as teaching only Italian and

\footnotetext{
${ }^{581}$ AdAM CE 1 T 2 Sous-préfet de Puget-Theniers au Préfet des Alpes-Maritimes, 24 Aug. 1810

${ }^{582}$ AdAM CE 1 T 5 Jury d'instrucion, certificate d'aptiude de J.B. Priori, 30 brumaire an XII (22 Nov. 1803)

${ }^{583}$ AdAM CE 1 T 5 Membres du conseil municipal de Lucéram au préfet des Alpes Maritimes

${ }^{584}$ AdAM CE 1 T 5 Maire de Castellar au préfet des Alpes Maritimes, 7 Oct. 1812

${ }^{585}$ AdAM CE 1 T 1 procès verbal du jury d'instrucion publique, 2e jour comp. an IX (19 Sept. 1801)
} 
Latin. For the year XII he was replaced by André Blanqui, ${ }^{586}$ who was to teach French at the school, but Robion regained the position in $1808 .{ }^{587}$ However, Robion claimed that he was unable to travel to Nice to undergo the examination required of all teachers due to a bad leg, ${ }^{588}$ leaving the prefect little choice but to allow the school to open without the jury having examined the teacher. ${ }^{589}$ Regardless of the truth of Robion's leg ache, only 77 teachers were approved for the arrondissement of Nice between Thermidor year II (1804) and March 1814, ${ }^{590}$ and since at least 72 were practicing in the area in1809 it is likely that Robion was not alone in teaching without having passed the jury's examination, assuming a modest turnover of schoolmasters.

Aside from the lack of rigour exercised by the juries of public education in the oversight of the department's teachers, the spread of French language education was also inhibited by opposition from the area's inhabitants. This opposition was particularly fierce in Roquebillière, a mountainous commune renowned as the source of numerous bands of barbets, the bandits that proliferated in parts of the department after its annexation to France. In the year XIII the mayor of the commune, wrote to the prefect confirming receipt of a set of affiches exhorting the population to learn French. The mayor wrote that his brother, also the local priest, had learnt French with a master of languages in Nice and was eager to teach it, but that thanks to

l'ignorance des pères et mères qui n'ont pas voulu procureur des livres à ses enfans, [sic] et par de malveillans [sic] qui toujours bruisent [sic] la prochaine arrivée des Russes, Prusses et Autrichiennes troupes et que ne serons bientôt plus français [... et qu'ils] ne seront plus obliger à faire étudier la langue française à ses enfans. ${ }^{591}$

\footnotetext{
${ }^{586}$ AdAM CE 1 T 6 Arrêté du maire de Roue, 10 brumaire an XII (2 Nov. 1803)

${ }^{587}$ AdAM CE 1 T 6 Maire de Roure au préfet des Alpes Maritimes, 10 Oct. 1808

${ }^{588}$ AdAM CE 1 T 6 Maire de Roure au préfet des Alpes Maritimes, 21 Nov. 1808

${ }^{589}$ AdAM CE 1 T 6 Préfet des Alpes Maritimes au maire de Roure, 5 Dec. 1808

590 AdAM CE 1 T 1 Instituteurs et institutrices approuvés pour les écoles primaires

${ }^{591}$ AdAM CE 1 T 4 Maire de Roquebillière au préfet des Alpes Maritimes 9 floréal an XIII (29 Apr. 1805)
} 
Three years later the mayor reported that, within the commune there were a number of antigovernmental agitators, and that some of them 'ne veulent point entendre parler la française'. ${ }^{592}$ While the commune's teachers were apparently willing to provide lessons in Italian as well as in French and Latin, two individuals amongst this group even set up an unauthorised Italian language school in a private house, which the prefect ordered closed. ${ }^{593}$

The inhabitants of the department were certainly not uniformly ill disposed towards French. The inhabitants of Nice were generally eager to teach their children the language, as they had been before the annexation of the country of Nice to France, to judge by the materials gathered by Joseph Levrot. This much was evident from the two distinct patterns of teaching in Villefrance, a commune just across a small inlet from Nice, in the year XI. The mayors response to Dubouchage's survey of that year names two teachers within the commune, Nicolas Galini, a Neapolitan priest who taught Italian and Latin, and a Frenchman, Joseph Anne, whose only profession was his teaching, and who taught French and handwriting. ${ }^{594}$ While Galini was paid 200 francs per year by the commune, Anne's income was made up entirely of the monthly fees paid by his students. However, despite being free for students to attend Galini's school had fewer pupils- 12 to Anne's 20. The reason for the disparity became clear when the prefect asked Anne to take up Galini's communal teaching post, for Anne refused the offer 'attendu que la vingtaine d'élèves qu'il a presque tous Niçois, et qu'il les a en pension chez lui, ils lui donnent de la besogne toute la journée, sans qu'il soit possible d'enseigner à d'autres, s'il venoient [sic] à fait école'. ${ }^{595}$ This was, of course, a pattern familiar from the correspondence received by Grégoire at the start of the Revolution, and evident in much of the geography of language teaching in the department. Learning French was the object of wealthy town dwellers, who were prepared to pay good money to a capable teacher of the language. Meanwhile other languages tended to find themselves taught only in rural areas. Whether arising from

\footnotetext{
${ }^{592}$ AdAM CE 1 T 6 Maire de Roquebillière au préfet des Alpes Maritimes, 12 Jan. 1808

${ }^{593}$ AdAM CE 1 T 6 Préfet des Alpes Maritimes au maire de Roquebillière, 18 Jan. 1808

${ }^{594}$ AdAM CE 1 T 1 Maire de Villefrance au préfet, 18 thermidor an XII (6 Aug. 1804)

${ }^{595}$ AdAM CE 1 T 1 Maire de Villefrance au préfet, 25 thermidor an XII (13 Aug. 1804)
} 
sentiment or from a rational appraisal of the relative advantages to be accrued from learning Italian or Latin over French, the reluctance to teach children a new language proved a significant barrier to change since many teachers relied on the fees paid by parents or at least the confidence of the municipal council. As the mayor of Lucéram explained, 'dans le plus pauvre des communes de la montagne, on l'enseigne point la langue française, et par une bonne raison parce que les pères et mères de moins le plus part retirtoient [sic] leurs enfens [sic] des écoles primaires si on ÿ [sic] enseigné la langue française'. ${ }^{596}$ Language teaching in the Alpes-Maritimes under Napoleon reflected older habits and the preferences of local communities far more than the will of the state and its operatives.

\section{The Enduring Appeal of the School as a Tool of Francisation}

Upon the establishment of the Imperial University in 1808 the new rector of the Academy of Aix, André Alexandre Eymar, appeared every bit as eager as Dubouchage to spread French to the schools of the Alpes Maritimes. Eymar wrote to one of the members of the jury d'instruction in Nice in May 1810 asking him which 'instituteurs [...] continuent d'enseigner en italien. Ils doivent être écartés de l'enseignement. On ne parviendra à donner au dépt des alpes maritimes les gouts les habitudes \& les mœurs français, en un mot à créer des français, qu'en instruisant dans la langue française.' ${ }^{597}$ However, when Dubouchage wrote to the Rector in September 1810 outlining the difficulties that he had encountered pursuing such a policy Eymar's response showed him to have become pessimistic about the chances of compelling the department's teachers to teach in French. ${ }^{598}$

Il serait bien à désirer, sans doute, que l’enseignement fut généralement donné en français; mais quel nombre infini d'instituteurs, qui n'ont peut-être pas d'autres moyens d'existence, seraient par-là privé de leur état [...] Je suis forcé de tolérer que quelques-uns correspondent

\footnotetext{
${ }^{596}$ AdAM CE 1 T 6 Maire de Lucéram au préfet des Alpes Maritimes 10 Oct. 1811

597 AdAM CE 1 T 2 Recteur de l'Académie d'Aix au Dubutel, 4 May 1810

${ }^{598}$ AdAM CE 1 T 2 Préfet des Alpes-Maritimes au Rector de l'Académie d'Aix, 12 Sept. 1810
} 
avec moi en italien, ce qui est pénible pour moi, parce que cette langue ne m'est pas familière..$^{599}$

The pessimism expressed by Eymar doubtless reflected the real practical difficulties of imposing French upon the schools of the Alpes Maritimes. However, his view of the importance of 'creating Frenchmen' through the teaching of the national language in the classroom were shared by many of those responsible for the administration of French schools both during and after the fall of Napoleon.

As the Alpes-Maritimes were ceded to the Kingdom of Sardinia in 1814 it is obviously impossible to follow the evolution of the French state's policy in the department under the restored Bourbon monarchy. However, France retained control of another area where Italian dominated the education system- the Island of Corsica. In 1822 a report compiled for the Minister of the Interior by the prefect of Corsica made clear that the fall of Napoleon had not seen the desire to replace Italian with French recede, and the prefect observed with some satisfaction that 'I'enseignement de la langue française rencontre moins d'antipathie que par le passé, et peut-être n'est-on pas éloigné de triompher de l'italianisme qui parait si naturel au Corses' ${ }^{600}$ Central to this progress was a religious congregation, the Brothers of Christian Schools, who found themselves at the head of French language teaching on Corsica. A table drawn up in 1811 of the primary school teachers in the department of Liamone (before its amalgamation to form the Department of Corsica), noted that just 8 out of 63 primary school teachers taught French. Of these, four were the Brothers of Christian Schools established in Ajaccio. In 1818, a report on primary education in Corsica observed approvingly that the Brothers' school established in Ajaccio, 'qui réunit au-delà de 250 élèves, a déjà produit une révolution sensible dans la langue $\&$ dans les mœurs de cette partie de la Corse. Les frères enseignent le français, en enseignant dans cette langue d'après la volonté expresse des 
fondateurs de leur établissement'. ${ }^{601}$ Teaching congregations in general and the Brothers in particular were frequently seen as an efficacious means of spreading French. In a lengthy dissertation on education sent to the prefect of the Haut Rhin in October 1801, the Mayor of Eguisheim eulogised the Brothers of the Doctrine and the Sisters of Providence, claiming that these two institutions could 'facilement introduire l'idiome françois [sic]'. ${ }^{602}$

Just as in Nice, the French state showed itself keen to spread the French language to the German speaking populations of Alsace. This much is clear from a letter written in February 1811 by the Rector of the Academy of Strasbourg to the Grand-Master of the University; 'd'après I'intention de votre excellence de parvenir à franciser ce pays, ce que n'a pu opérer encore sa réunion à la France depuis un siècle et demi, il est important d'apporter une extrême attention au choix des instituteurs primaires'. ${ }^{603}$ As with Italian in Corsica, the 'foreign' nature of the language continued to mark the region out as a priority after the Restoration. According to an 1811 report from one of the inspectors of the Academy of Strasbourg, spreading French in the area was 'd'un grand interêt national sur une frontière où l'allemand n'est point, comme le patois d'autre parties de la France, l'idiome particulier du pays qui s'en sort, mais la langue des contrées étrangères qui nous entourent de trois cotés'.604

The initial efforts to this end closely resembled those taken in the Alpes-Maritimes. In August 1812, one of the inspectors of the Academy of Strasbourg proposed a series of new regulations for the primary schools of Alsace ${ }^{605}$ Convinced that pupils would not be able to handle a bilingual education, the inspector sought to position French as the dominant language in the Academy's schools. Thus the fifteenth regulation read

\footnotetext{
${ }^{601}$ An F17 9367 (Rapports des Recteurs sur l'enseignement primaire) Rapport sur l'instruction primaire en Corse, inspection de 1818

${ }^{602}$ AdHR 1 T 2 (Enquête sur la situation de l'instruction publique) Canton d'Eguisheim

${ }^{603}$ An F17 9367 Recteur de l'Académie de Strasbourg au Grand-Maitre de l'Université 19. Feb. 1811

${ }^{604}$ An F17 9367 Rapport sur les écoles primaires, fin 1811

${ }^{605}$ An F17 9367 Académie de Strasbourg, écoles primaires, projets de réglements, 9 Aug. 1812
} 
La langue français étant le seul idiôme avec lequel il importe de familiariser les peuples de l'Empire, on n'enseignera qu'à lire et à écrire en français dans les classes intermédiaire et supérieures de chaque école primaire de la ville de Strasbourg, à compter du $1^{\mathrm{er}}$ janvier 1815 et plus tôt si cela est possible. Dans la classe inférieure [...] on fera lire et écrire en français et en allemand, mais on donnera beaucoup moins de tems [sic] à cette dernière langue qu'à la première. ${ }^{606}$

In addition to this, and again closely mirroring Dubouchage's efforts in the Alpes-Maritimes, the sixteenth regulation stipulated that 'aucun instituteur ne sera commissionné soit en qualité d'instituteur titulaire, soit en qualité d'instituteur adjoint, s'il ne justifie qu'il sait lire et écrire correctement en français, et qu'il est en état d'enseigner aussi en français les premiers notions du calcul'. ${ }^{607}$

However, amongst the papers sent to the Ministry of the Interior during the Restoration period by Academy of Strasbourg there is another project that approached the question in a different way. The author of this unfortunately anonymous and undated manuscript begins with the observation that 'la plupart des Instituteurs n'en ont pas la moindre connaissance [du français], il est cependant dans l'intérêt de la localité et d'une grande gouvernance nationale que l'usage de cette langue se propage'. In order to circumvent this difficulty, a series of tables containing both French and German were proposed. The first such table would contain, in both French and German characters, the sounds represented by the same sign in both languages, for example ba ba, bi bi, bo bo etc. The intention was for the schoolteacher to read the German syllable followed by the French one, demonstrating how the same sounds were represented by the two different languages to the pupils. ${ }^{608}$ This first table was to be supplemented with a second, of similar sounds with different symbols, a third showing different sounds that are represented by the same symbol, a fourth of French vowels and final table with signs and sounds in French that do not have an analogue in German. The idea was that the teacher reading and pronouncing the German would be able to teach French pronunciation even if he did not speak the language. In the words of the author, '[l]es

\footnotetext{
${ }^{606}$ An F17 9367 Académie de Strasbourg, écoles primaires, projets de réglements, 9 Aug. 1812

${ }^{607}$ An F17 9367 Académie de Strasbourg, écoles primaires, projets de réglements, 9 Aug. 1812

${ }^{608}$ An F17 9367 Plan d'enseignement élémentaire de lecture dans les deux langues pour les écoles primaires d'Alsace
} 
tableaux [...] le guident, comme ils guident les élèves: le tableau est le véritable maître des deux à la fois' ${ }^{609}$

Esoteric though this scheme may have appeared, it did represent a trend in the German speaking areas of the east of France to work around the issues posed by the endurance of these foreign languages and the perennial difficulty of a lack of Francophone teachers. In 1818 the conseil général of the department of the Moselle in Lorraine proposed the creation of a bilingual école normale to train teachers in both French and German. Ten years later the Rector of the Academy of Strasbourg proposed a set of cheap books with the text in both German and French be printed. The year after that he had a dormitory built in Belfort, the French speaking arrondissement of the Haut Rhin, allowing students to travel to an area where French was the native language so that they might pick up the pronunciation. ${ }^{610}$ In 1833 the Rector of the Academy of Nancy proposed a bilingual catechism, so that 'le Pasteur ne pourroit [sic] plus dire que les livres écrits dans cette langue française soit dangereux pour la religion et les mœurs' ${ }^{611}$ The French state continued to strive to spread French in Alsace despite the political change taking place during the period.

\section{The Linguistic Legacy of Napoleonic Rule in the Alpes Maritimes}

The men employed by the French state to oversee the country's education system shared a common vision of the school and its role in nation building, at least when it came to language. Whether from a fear of linguistic separatism, a desire for linguistic egalitarianism or a sense of national identity, the classroom was seen as a conduit through which national and local space might be linked. It was hoped that the flow of cultural practices and knowledge, such as language, through the classroom could anchor population and territory within realities beyond the local. Sometimes such efforts were repressive, involving a prohibition on the use of languages other than French in

\footnotetext{
${ }^{609}$ An F17 9367 Plan d'enseignement élémentaire de lecture dans les deux langues pour les écoles primaires d'Alsace

${ }^{610}$ An F17 9367 Recteur de l'Académie de Strasbourg à MM les préfets 7 jul. 1828 and 6 Aug. 1829. Such exchanges certainly took place during the second empire- AdHR 1 T 887 (Echanges entre les cantons francophones et germanophones)

${ }^{611}$ An F17 9368
} 
the classroom. The most violent of these methods was known as the symbole, a technique that was first described approvingly by Dufilhol in his 1833 report. The technique, according to Dufilhol, involved a piece of wood which would be given to the first child who spoke in Breton. Whilst holding this piece of wood the child was forbidden from participating in playground games with his or her classmates. The piece of wood could be passed on only by catching one of the child's classmates speaking Breton. ${ }^{612}$ For many modern Breton speakers, particularly Breton language activists, the symbole is seen as an especially pernicious manifestation of the French state's repression of ethnic and linguistic difference, particularly despised for the way it was used to stigmatize children's native tongue from a young age. ${ }^{613}$

Brittany was not the only part of France where school inspectors expressed a desire to prohibit the use of other languages in the classroom, and embed French as the sole language of instruction. The same year that Dufilhol expressed his approval of the symbole, a report on primary education in the Academy of Pau identified 'les idioms Basque et patois [Gascon], les seuls que l'on parle hors des villes, ${ }^{614}$ as one of the main obstacles to the spread and improvement of primary education, along with the region's sparse settlement pattern, poor communications, the poverty of its inhabitants and the lack of suitable school buildings. The report advocated that teachers 'défendre en classe l'usage de tout autre idiôme [sic] que la langue nationale'. ${ }^{615}$

However, it seems unusual for teachers to employ such repressive measures during the period. More frequently efforts were focused on overcoming the lack of French speaking teachers, sometimes in quite creative ways, as in the Academy of Strasbourg where comparative tables and pupil exchanges took the place of injunctions to speak in French. This is not to minimize the scope of the French state's ambitions in the field of education. Lawmakers and administrators charged with managing the educational system indisputably understood spreading the French language to be

\footnotetext{
${ }^{612}$ An F17 9368 Inspections des écoles primaires de l'arrondissement de Brest (extra-muros) 1833

613 McDonald We Are Not French! pp. 46-9

${ }^{614}$ An F17 9368 Rapport sur l'état général de l'instruction primaire dans l'Académie de Pau, 1833

${ }^{615}$ An F17 9368 Rapport sur l'état général de l'instruction primaire dans l'Académie de Pau, 1833
} 
central to their mission. This impulse towards linguistic imperialism was also one that transcended the political divisions and ruptures of the period. It was an explicit aim from the Revolution to the July Monarchy and beyond.

As the examples drawn on above show, particularly those from the Alpes-Maritimes, the role of the classroom cannot be reduced to the centralizing impulse of policy makers at the centre. Primary schooling continued to reflect the priorities of local society. In areas where French as the ' $\mathrm{H}$ ' variety dominated literate culture teachers were obliged to work in the language of the capital. In contrast, where another language functioned as the ' $\mathrm{H}$ ' it tended to dominate the classroom despite the efforts of Napoleonic administrators. This conclusion reflects the findings of Jean-François Chanet who has demonstrated how, even with the reach of the state at its most all-encompassing within the sphere of education, classroom practice frequently eluded the clasping centralised diktats of the Third Republic, through the use of the local language or local culture. ${ }^{616}$ Certainly the example of the Alpes Maritimes shows how the classroom was a domain responsive to the demands of local society. The schoolroom was a hinge between the local and the national, in which useful forms of official knowledge could be disseminated, but were likely to find an audience only where local practices provided a market for them. Analysis, therefore, must focus on the strategies of social actors, the use to which forms of knowledge could be put, rather than a straightforward opposition between the local and the national.

Perhaps the clearest indication of this process of negotiation between the national and the local can be found in the legacy, or rather the lack of one, that Napoleonic educational policies left in the classrooms of the Alpes Maritimes. During the nineteenth century the restored Sardinian monarchy revealed itself to be somewhat concerned by the use of French in the schools of the county of Nice. In October 1850 it distributed a survey of its own, with question six intended to establish if the schools in each of the region's communes were conducted in French or Italian. The

${ }^{616}$ J.F. Chanet, L'école républicaine p.25 
responses this survey generated show that, in 1850, 44 communes had French schools, 11 had Italian schools. ${ }^{617}$ Yet plotting the geographic distribution (Figure 11) of this data reveals that these French schools were clustered in the North West of the county, exactly where they had been found fifty years earlier under the empire, in the territory of the old diocese of Glandèves. Despite the efforts of administrators, the language in which a commune's school was held was determined not by the state in which it was found, but by the border of a religious district that no longer existed. As this shows, the value of linguistic knowledge was not necessarily determined at the centre, but rather was embedded in local linguistic practice.

${ }^{617}$ AdAM FS 433 (Statistique général) 


\section{Language, Law and the Legal Profession: Negotiating Cultural Identity in an Imperial Institution}

The law as a set of institutions- courts and the judges who staffed them, the lawyers who pleaded before them, the documents offered up as evidence and the notaries who drafted them- have long been understood as a tool of state building. Such projects have frequently involved an effort to consolidate the sovereign's monopoly on the administration of justice through the abolition of legal particularism and the creation of a professional, centrally controlled judiciary, all the better to enforce the extraction of tax and soldiers. ${ }^{618}$ Given that France is so frequently understood as a paradigmatic civic or state-nation, wherein national identity is said to arise from existing state structures, it is unsurprising that French legal institutions have often been implicated in processes of cultural integration and nation-building, and particularly in the spread of the French language. ${ }^{619}$

The invariable touchstone for such accounts of linguistic integration driven by legal institutions is the ordinance of Villers-Cotterêts, promulgated by François I in 1539. This ordinance required that all legal documents, including registers, commissions, inquests, contracts and wills, 'soient prononcez enregistrez et deliverez aux parties en langage maternel françois et non autrement' ${ }^{620} \mathrm{~A}$ few years after the 1860 annexation of the county of Nice to France, Émile Negrin reflected on the significance of Villers-Cotterêts for the language of the south of France:

Peu s'en fallut que, sans François $1^{\text {er }}$, le Provençal ou langue d'Oc ne devint notre langue nationale et partant une langue classique comme la Française, l'italienne, l'Espagnole et la Portugaise, quatre sœurs. François $1^{\text {er }}$, dans l'art. 111 de l'édit de Villers-Cotterêts, ordonna que les arrêts fussent rendus « en langage françois et non aultre » ce qui par la vulgarisation détermina la prépondérance et la victoire de la Langue d'oïl. ${ }^{621}$

In the first part of the twentieth century, both the nature and broader significance of Villers-

Cotterêts became the subject of some debate. ${ }^{622}$ The ordinance was specifically designed to end the

\footnotetext{
${ }^{618}$ Bayly, Modern World pp.261-4 ; Woloch, New Regime pp.429-31

619 J.A. Fishman, Languages and Nationalism, Two Integrative Essays (Rowley, 1975) pp.24-7 ; Kamusella, Politics of Language p.25; Thiesse création des identités nationales p.12

${ }^{620}$ Lodge, Dialect to Standard (London, 1993) p.126

${ }^{621}$ E. Negrin, Les Promenades de Nice (Nice, 1867) p.97

622 D. Trudeau, 'L'ordonnance de Villers-Cotterêts et la langue française : Histoire ou interprétation' in Bibliothèque d'humanisme et renaissance vol. 45 no. 3 (1983) pp.461-72
} 
use of Latin in legal and administrative contexts throughout the kingdom, but it is not clear which language or languages were intended to replace it. Prominent scholars like Henri Peyre argued that the ambiguous wording of the ordinance, 'langage maternel françois', transcribed by Negrin in a telling slip as 'langage françois', did not preclude the use of regional languages, but followed earlier royal edicts that had excluded Latin but explicitly permitted regional languages such as Occitan and French in official business. ${ }^{623}$ In contrast, August Brun, along with Ferdinand Brunot, maintained that Villers-Cotterêts had represented a decisive shift in monarchical language policy towards enshrining French as the sole language of state. ${ }^{624}$

Regardless of the intended outcome, Villers-Cotterêts was emblematic of a shift towards French in administrative and political contexts, which saw the language of the royal court displace regional languages across much of the kingdom by the end of the sixteenth century right down to the level of the town council. ${ }^{625}$ During the seventeenth and eighteenth century Royal officials certainly interpreted the text to mean French rather than the language of France, and imposed it upon newly annexed territories. ${ }^{626}$ However, this impulse towards spreading French was largely focused on written contexts and was accompanied only by rather perfunctory efforts to spread French to the royal colleges intended to train administrators. ${ }^{627}$ Moreover, while enshrining French as the language of administration undoubtedly gave it currency as a medium of elite expression, particularly in written contexts, the linguistic culture of sixteenth-century France was undergoing a transformation at precisely this time. Renaissance scholars valorised the vernacular at the expense of Latin in all spheres of written production. It is difficult to dissociate the impact of Villers-Cotterêts from these trends, much less determine the influence it had on the 'vulgarisation' of French. ${ }^{628}$ Nonetheless, perhaps convinced by the fairly dramatic linguistic changes which took place in Nice

\footnotetext{
${ }^{623} \mathrm{H}$. Peyre, La Royauté et les langues provinciales (Paris, 1993) p.78

${ }^{624}$ A. Brun, 'En Langage maternel françois' in Le Français moderne 19, (1951) pp.81-6 ; Brunot, HLF vol. 2 pp.30-32

${ }^{625}$ Lodge, Dialect to Standard pp.122-7; Cohen, Courtly French p.696

${ }^{626}$ Sahlins, Boundaires pp.116-9; Brunot, HLF vol. 5 pp.89-93

627 Sahlins, Boundaries p. 116

${ }^{628}$ Brunot, HLF vol. 2 pp.36-92; Lodge, Dialect to Standard pp.127-30
} 
after 1860 , Negrin attributed a great value to the capacity of a government to fix the language of legal texts. ${ }^{629}$

The provisions governing the use of language in legal texts set out by Villers-Cotterêts probably had as much significance under Napoleon as at any other point since 1539 . The wars of the Revolutionary and Napoleonic period brought unprecedented numbers of non-French speakers under the rule of Paris, and these populations were to be governed by French law. Legal commentators of the period even continued to cite Villers-Cotterêts. One author of a guide for notaries wrote, 'les notaires doivent rédiger tous leurs actes en langue française. C'est ce qui a été statué par l'art. 111 de l'ordonnance donné par François $1^{\text {er }}$ à Villers-Cotterêts, au mois d'août $1539^{\prime} .{ }^{630}$ The ordinance was cited by no lesser a legal authority than Joseph-Antoine Merlin de Douai, who was named procureur impériale at the Paris cour de cassation following a controversial stint as minister of justice under the Directory. In his article on court interpreters, Merlin observed that not only written documents, but 'les procédures en langue vulgaire du pays, furent [...] absolument abolies par cet article', implying that legal hearings should take place in French. ${ }^{631}$

These arguments would seem to underscore the kind of interpretation put forward by Negrin over Villers-Cotterêts; namely that the French legal system functioned as a handmaiden for linguistic imperialism during the Napoleonic period. Such an expectation might seem doubly plausible in a context where, as will be shown, the law was an ideologically charged tool of empire building, which administrators expected to facilitate the integration of diverse populations and territories into a cohesive French state. However, this chapter will argue that the quotidian experience of justice, at least from a linguistic point of view, was little changed by such efforts. This was because in practice the French legal institutions encountered most frequently by the

\footnotetext{
${ }^{629}$ French quickly became the language of the commercial and governmental elite of Nice, although this was due in large part to emigration patterns following annexation. S. Wright, 'Fixing National Borders : Language and Loyalty in Nice' in P. Gubbins and M. Holt (eds.), Beyond Boundaries: Language and Identity in Contemporary Europe (Clevedon, 2002) pp.91-100 630 A.-J. Massé, Le Parfait notaire ou la science des notaires (1809) p.56

${ }^{631}$ P.A. Merlin, Répertoire universel et raisonné de jurisprudence, vol. 6 (Paris, 1808) p.432
} 
population- the notary and the local magistrate or juge de paix - tended to remain linguistically flexible even if they were obliged to write in French. This crucial fact was as true in the non-French speaking parts of Old France as it was in the territories annexed following 1789 . This is not to argue that French linguistic policies in the law courts were irrelevant. On the contrary, they put a great deal of pressure amongst the local legal elites who collaborated with the French. Under Napoleon, Paris controlled the appointment of legal officials, and a grasp of the French language was greatly valued. Combined with increasing legal pressures to work in the language, this sparked ethnolinguistic tensions within the judiciary of the départements réunis, calling the cultural identity of many individuals into question. Judges were invited to acculturate, to align themselves with the Napoleonic project, and language thus became a proxy for issues of loyalty and identity.

\section{Napoleonic Integration and the Law}

The application of the French legal system was central to the Napoleonic project and its legacy. It is an often repeated observation, but no less significant for this familiarity, that many features of the Napoleonic model of administration survived and prospered across Europe long after the empire itself had shrivelled. In the Rhineland, the Napoleonic code was retained, in the French language, when the region fell under the control of the Prussians, who themselves adopted it in German translation in $1851 .{ }^{632}$ The Netherlands retained the code and French judicial structures until 1827, and these were restored in Belgium following the 1830 revolution. ${ }^{633}$ While the code was abrogated in Italy, certain Napoleonic administrative, financial and judicial institutions were conserved in fact, if not in name. Even in Piedmont, where the restoration was pursued with vigour by Victor Emmanuel I, who abolished all French legislation and returned to the judicial system of the Ancien Régime, French judicial practices remained popular in liberal political circles. ${ }^{634}$ When Charles

\footnotetext{
632 Broers, Europe under Napoleon p.267

633 J.-P. Nandrin, 'La Cour de cassation belge de 1832 et le pouvoir judiciaire' Justice et institutions françaises en Belgique (1795-1815) : Traditions et innovations autour de l'annexion : Actes du colloque tenu à l'université de Lille II, June 1995 (Hellemmes, 1996) pp.276-7

634 J.A. Davis, Conflict and Control: Law and Order in Nineteenth Century Italy (Basingstoke, 1988) p.23 ; Broers, Napoleonic Empire in Italy p.177
} 
Félix reformed the Piedmontese judicial system in 1822 the model that inspired him came from the other side of the Alps. ${ }^{635}$

Evaluating such observations on the legacy of French domination requires some idea of the shape of the French legal institutions- or as Jean Hilaire has described it, the French judicial modelthat the Revolutionary and Napoleonic regime attempted to apply across the Empire. It also calls for a sense of how this model differed from what it replaced. ${ }^{636}$ This is not only a question of law and institutional structure, but of procedure, personnel and mind-set, of what might be called legal culture. It is also a question of how the institutions and personnel of law and order related to the societies which they sought to regulate. The second part of this chapter will deal with the significance of language in the context of personnel and legal cultures. In the initial part, however, the focus will be on the institutional aspect of the French judicial model.

The institutional features of the French judicial model exported under Napoleon grew out of the Revolutionary period. After the summer of 1789 , the administration of justice became a focus for politicians. Initially, the constituent assembly, well aware of the lengthy tussles that had unfolded between the royal government and the parlements during the eighteenth century, replaced the latter with a completely new court system. Civil and criminal law were separated, with a criminal court established in each department and a civil court in each district, later replaced by a departmental court when the districts were abolished under the Directory. Juries were established for criminal trials, but not for civil courts, which were regulated initially by a rotating system of appeals in which one district court heard appeals on verdicts handed down in another. The Revolution also saw Seigniorial justice replaced with the juges de paix, many of whom were legal

\footnotetext{
${ }^{635}$ P. Alvazzi del Frate, 'La Justice française en Italie La politique judiciaire dans les départements italiens de I'Empire Napoléonien' in Justice et institutions françaises en Belgique p.199

${ }^{636} \mathrm{~J}$. Hilaire, 'L'influence du modèle judicaire français en Europe sous la Révolution et l'Empire : Un Cliché en question', Influence du modèle judicaire français en Europe sous la Révolution et l'Empire : Actes du colloque tenu à I'université de Lille II, Juin 1998 (Lille, 1999) pp.1-7
} 
amateurs, who were expected to arbitrate in small scale local disputes ${ }^{637}$ Following the coup d'état of the $18^{\text {th }}$ Brumaire, these institutions underwent another transformation, though certainly one of lesser magnitude than that which had followed the Revolution. The district civil courts returned as tribunaux de première instance, one of which was established in each arrondissement. Overseeing them at the departmental level was a series of new appeal courts. Crucially, the juges de paix were retained, although they were now expected to cite principles of law when judging disputes, rather than simply resolving them in an 'equitable' way. ${ }^{638}$

Perhaps the greatest single continuity from Directory to Napoleonic regimes was the ideological significance of the reformed legal system within broader projects of state building. Rationalising laws and unifying institutional structures remained a constant priority from the abolition of the parlements by the Constituent Assembly in November 1789 to the imposition of the Napoleonic judicial model on the territories annexed throughout the period of the Empire. This continuity was neatly demonstrated on the $5^{\text {th }}$ Frimaire of the year VIII, just short of a month after Napoleon's coup d'état of the $18^{\text {th }}$ Brumaire, when the new tribunal de cassation of the four departments of the left bank of the Rhine was installed at the town of Trier with a ceremony of oath taking and distinctly Republican pomp. Bell ringers were joined by the sound of trumpets and artillery salvos as a cortege comprising the luminaries of the local administration, judiciary, military, and gendarmerie as well as local teachers and their pupils, wound its way towards what was still described in the official record as the 'temple décadaire'. Inside the temple, which was decorated with the colours of the nation and other 'symboles de la liberté', the members of the court took their oaths of loyalty and duty to cries of 'Vive la république française !' and 'Vive la liberté, l'égalité et la fraternité!'. Following the ceremony, the soldiers and gendarmes in attendance left singing patriotic hymns, while the various officials and officers, along with the presidents of the constituent authorities of Trier, attended a banquet. This dinner, 'civic and fraternal' in character, saw toasts

\footnotetext{
${ }^{637}$ The very brief outline given here is derived from Isser Woloch's excellent synthesis; Woloch, New Regime pp.302-20

${ }^{638}$ Woloch, New Regime pp.317, 339
} 
made to the Republic, to Liberty, to the victorious armies of the nation, to the union of the four departments of the Rhine with France, and perhaps most ironically given recent events in Paris, to the système représentatif. ${ }^{639}$

The kind of propaganda represented by this description of the ceremony, characterised by such florid republicanism, was already something of an anachronism. In the new year, the hated Jacobin commissarie of the Rhenish departments, Joseph Lakanal, was replaced by Henri Shée, a change of personnel accompanied by a shift in both the style and character of French rule of the region. Jacobins were purged, the French prefectoral system was finally implemented in full and the presentational emphasis was shifted onto stability and the restoration of order. ${ }^{640}$ Yet for all this, the installation ceremony of the tribunal de cassation in Trier also prefigured Napoleonic rule in an important way, for with its tricolours and public oaths and public toasts it made manifest the centrality of the administration of justice to the way in which the French government projected and understood its authority, a centrality that would become one of the defining characteristics of Napoleonic rule. Napoleonic administrators were expected to take part in all manner of public civic engagements; processions, festivals, feasts and balls, and the judiciary took up a prominent place at these events. ${ }^{641}$ Under Napoleon, Bastille day celebrations gave way to celebrations of the birth of the king of Rome and the St Napoleon festivities, and they took place in a church rather than a temple of the supreme being, but the judicial elite of the Napoleonic empire was still expected to take up a prominent position behind the civil authorities in the processions leading to and from the church. In general, the highest civil authority, which would be the prefect in the chef lieu, headed the procession, followed by the commander of the gendarmerie, with the president of the highest law court in third place, followed by the mayor. ${ }^{642}$

\footnotetext{
${ }^{639}$ An BB5 256 (Organisation judiciaire- Cour de Trèves) Procès-verbal de l'installation du tribunal de révision crée pour les quatre départements de la rive gauche du Rhin, 5 frimaire an VIII (26 Nov. 1799)

${ }^{640}$ Rowe, Reich to State pp. 87-90

${ }^{641}$ Woolf, Napoleon's Integration pp.217-9; Rowe, Reich to State pp.92-3

${ }^{642}$ An BB5 297 (Organisation judiciaire- Apennins) Oliveri, président du tribunal de première instance de Chiavari au Min. de la Justice, 16 Aug. 1808
} 
Such processions mattered greatly to those involved, generating the kinds of disputes over precedence that characterised the ceremonial life of courts, parlements and other legal and civic bodies of early modern Europe. ${ }^{643}$ Yet the ceremonial exercise of power also had tremendous significance as propaganda, and the administration of justice was central to the claims made for the legitimacy of French rule. The account of the installation of the court at Trier was printed and distributed to all the cantons throughout the four departments of the Rhine. ${ }^{644}$ Reproduced in this pamphlet was the speech given at the ceremony by the new president of the Trier court, who claimed that the ultimate aim of the judges over whom he presided would be to win support for French rule through the fair administration of justice:

Heureux si par nos principes et notre exemple, nous parvenons à leur faire désirer de plus en plus la réunion de leur territoire; et si enfin nous les voyons définitivement associés aux avantages et à la prospérité de la grande Nation! Hâtons-nous, citoyens juges, de répondre au désir de nos justiciables. Donnons-leur dès aujourd'hui, une preuve de notre zèle à remplir nos devoirs. ${ }^{645}$

As the rhetoric deployed by the president demonstrates, the French sought to justify their rule in the territories they conquered during the Revolution through the efficient governance of society, and this meant the efficient administration of the rule of law. Such claims to legitimacy, along with the impressive calendar of civic events organised by Napoleonic administrators, often failed to resonate in the shadow of material hardships caused by French economic policy. ${ }^{646}$ Yet the notion that good governance and legal administration would demonstrate the benevolent nature of French rule and the benefits of membership in the 'grande nation' remained strong amongst French administrators.

\footnotetext{
${ }^{643}$ An BB5 297 (Apennins) Oliveri, président du tribunal de première instance de Chiavari au Min. de la Justice, 16 Aug. 1808. At the festival of St. Napoleon in Chiavari in 1808. Oliveri complained that Charvillak, the imperial prosecutor of the criminal court, had usurped his place at the head of the procession in the absence of the prefect, general of the gendarmerie and president of the criminal court.

${ }^{644}$ An BB5 256 (Trèves) Commissaire du gouvernement près l'administration centrale du département de la Sarre, 19 frimaire an VIII (10 Dec. 1799)

${ }^{645}$ An BB5 256 (Trèves) Procès-verbal de l'installation du tribunal de révision crée pour les quatre départements de la rive gauche du Rhin, 5 frimaire an VIII (26 nov. 1799)

${ }^{646}$ As in Hamburg, where the hardships of French military occupation and economic policies overshadowed reforms in areas like justice that were otherwise popular with the commercial and political elites of the city. See Aaslestad, Place and Politics pp.245-51
} 
This was more than so much rhetoric and propaganda. During the Revolutionary and Napoleonic period, legal institutions were not understood simply as a mechanism to facilitate the extraction of ever greater quantities of men and lucre, even in those annexed territories that suffered the material extractions of the state. They were also legitimated, at least in the rhetoric of administrators describing the French legal system, as a tool for spreading civilization, even liberty, as contemporary French politicians strove for the ideal of universal laws applied by a consistent judicial structure. ${ }^{647}$ They were, in short, viewed as a way of integrating the diverse populations of the French empire. The creation of the tribunal de cassation at Trier, as the president sought to make clear at the installation ceremony, sprung from this commitment to a rationalised, or in the terminology of Mona Ozouf, regenerated, system of justice. In 1797, following the cession of the Rhineland by Prussia and Austria, François Rudler was appointed commissaire du gouvernement, charged with implementing French law and establishing French institutions in the region. Rudler achieved this through administrative fiat, issuing a huge number of decrees. ${ }^{648}$ However, during this period, before the official annexation of the departments of the Rhineland following the treaty of Lunéville in 1801, the law courts of the region had found themselves in an ambiguous position. The lower echelons of the French legal system had been erected, but unlike across the rest of France the cour de cassation in Paris did not function as the ultimate chamber of appeal for judgements handed down in the Rhineland. Instead, the Minister of Justice ruled personally on appeals, a process denounced as despotism in Le Nécessaire, ou courrier du corps législatif et de la guerre; 'si l'on vouloit établir une tyrannie odieuse et terrible, trouveroit-on un système qui la favorisât davantage que cette monstrueuse réunion de pouvoirs' ${ }^{649}$ The tribunal de cassation in Trier was intended to correct this anomaly, underlining how a unified and coherent judicial model was not only a

\footnotetext{
${ }^{647}$ M. Broers, 'The Napoleonic Empire', in A. Forrest and P.H. Wilson (eds.), The Bee and the Eagle: Napoleonic France and the End of the Holy Roman Empire (Basingstoke, 2009) p.70 ${ }^{648}$ Rowe, Reich to State p.59

649 'Observations sur les nouveaux départemens de la rive gauche du Rhin', Le Nécessaire ou courrier du corps législatif 25 Thermidor an VII (12 Aug. 1799)
} 
significant part of the symbolic exercise of French power after the Revolution, but also a central element of the aims of the regime..$^{650}$

\section{Language Policy and the Law from the Revolution to Napoleon: Governing the Written Word}

The paradox of a homogenous judicial model of this type is that it can produce very different outcomes when it encounters different social and cultural conditions. For example, changes to property rights, and in particular the abolition of the right to dispose of property through wills in 1793, caused far greater disturbance in the South than in the North. This was because the greater scope to designate inheritance by testament granted under Roman law had fostered a sort of 'common primogeniture' as a way of keeping smallholdings viable. ${ }^{651}$ Similarly, historians have observed a divergence in the status and importance of the juge de paix in different parts of France. The pivotal role of the juge de paix in some regions seems to have come down to the poverty of agricultural production, which in turn produced smaller civil cases of the sort that usually did not go up to the local tribunal. ${ }^{652}$ Curiously, as Bernard Schnapper has shown in examining the rates of litigation throughout France during the nineteenth century, there also existed an enduring division between the pays du droit écrit or Roman law of the South, and the pays du droit coutumier of the North. In general, the populations of the South displayed a greater propensity to seek redress from the legal system, a fact it is difficult to explain except as the manifestation of a distinct litigious culture or mentality. ${ }^{653}$ Perplexing, yet a striking example of how different populations can respond in very different ways to an identical, centralised institution.

This being the case, one might expect language to have played a significant role in the way populations related to the judicial system in France. After all, as we have seen, the institutions of the justice system were an important symbolic manifestation of state power. It should also be recalled

\footnotetext{
${ }^{650}$ An BB5 256 Rapport au directoire exécutif sur le mode provisoirement établie pour la décision des demandes en cassation, contre les jugements des tribunaux des 4 départements de la rive gauche du Rhin ${ }^{651}$ P.M. Jones, The Peasantry in the French Revolution (Cambridge, 1988) p. 252

${ }^{652}$ B. Schnapper, 'Pour une géographie des mentalités judiciaires : La Litiogisité en France au XIXe siècle' in Annales E.S.C. (1979) no. 2 p.412

${ }^{653}$ Schnapper, 'géographie des mentalités judiciaires' pp.416-7
} 
that the French legal system for several centuries had been a Francophone one. In a context where the institutions of the justice system played a prominent role in state efforts to integrate the diverse populations of the empire, one might hypothesise that linguistic diversity would make these institutions more contentious. It could be supposed that a system working in a language other than the mother tongue of locals would be contentious by its very nature, encouraging local populations to seek redress through other mechanisms, such as violence or the mediation of the local curé. The data studied by Schnapper, unfortunately, begins only in the 1830 s, yet it is already clear that the populations of the South made relatively greater use of the justice system, not only of the tribunals one might expect the richer local inhabitants to turn to, but of the juge de paix who resolved all manner of petty disputes over property and contracts.

Understanding the role of language in this dynamic between population and judicial system requires us to distinguish between the different types of communicative encounters as they were identified and regulated by the French judicial model. Undoubtedly the most significant distinction in the way the French system regulated the language of legal activity can be drawn between written and oral contexts. In general, formulations of language policy at the centre have privileged the written word over the spoken, reflecting the dominance of grammaticality in French political discourse on the subject of language. During the Revolution, it was common for politicians agitating for action on the language issue to conflate literacy and language. When the Abbé Grégoire argued that French had to become the language of the nation so that all citizens might participate in the business of government, he explicitly transposed the issue into the realm of written, rather than spoken, language. According to Grégoire, legal acts could function as a guarantee of citizens' rights only if they were correctly drafted. Errors in the language and composition of such documents, in contrast, would undermine their efficacy. ${ }^{654}$ The emphasis placed on the written word by Grégoire is significant. His concern, it seems, was not primarily with spoken communication, but with written documentation, and it arose out of a legalistic concern for clarity and accuracy. Documents that

${ }^{654}$ Grégoire, 'Rapport', in Certeau et. al., Politique de la langue p.335 
were drafted in inaccurate terms, it was feared, would produce misunderstanding, error, and eventually injustice, whether they were legislative bills or legal acts.

Legalistic concern for the integrity of written documentation governed much Revolutionary and Napoleonic language policy. Some of the most notorious legislation regarding language passed by the National Assembly during the Revolution concerned just this issue. The law of 2 Thermidor year II (20 ${ }^{\text {th }}$ July 1794$)$ effectively reiterated the demands of Villers-Cotterêts, requiring that 'Nul acte public ne peut, dans quelque partie que ce soit du territoire français, être écrit qu'en langue française' ${ }^{655}$ This measure was repealed six weeks later, on the 16 Thermidor year II ( $2^{\text {nd }}$ September 1794), but on the 21 vendémiaire year III (12 ${ }^{\text {th }}$ October 1794$)$ the dominance of French over public documentation was re-established with a law requiring public functionaries to draft acts in French, a law cited by Merlin when he asserted that French was the official language of the justice system. ${ }^{656}$ These provisions were a significant departure from the language policy of the earlier period of the Revolution, when efforts were made to translate the laws and decrees of the assembly into the other languages used across France. In parts of the south of France, Toulouse for example, this seems to have taken on the character of political missionary work; the object was to speak to the 'people' in their own language, so as to win them to the cause of the Revolution. ${ }^{657}$ In Alsace, the translation policy was explicitly understood as part of a Revolutionary transformation in the way individuals related to the institutions of state, and the measures taken to promote linguistic uniformity during the year II were hated within the political clubs of the major towns.

Strasbourg was a particular locus for opposition to these measures, reflecting the enduring importance of German to literate elite culture in a city which retained a German-speaking university. ${ }^{658}$ Members of the political clubs in Strasbourg saw this as an opportunity to reshape judicial and state institutions to make them more representative of the local population, and above

\footnotetext{
${ }^{655}$ Bulletin des lois (1794) no. 25

${ }^{656}$ Bulletin des lois (1794) nos. 51, 72 ; Merlin, Répertoire universel p.432

${ }^{657}$ Maciak, 'Learning to Love the Republic' pp.173-4

${ }^{658}$ Bell, 'Nation-building', pp.476-7
} 
all more responsive to the linguistic demands of the majority of Alsatians. On the $6^{\text {th }}$ July 1790 , André Ulric addressed the Société des amis de la constitution of Strasbourg, claiming that the linguistic demands of the crown had served to alienate the population from these institutions:

Jusqu'à ce jour, les Administrateurs et les Juges ne s'adressaient à eux que dans une langue qui leur était absolument inconnue. Les contrats étaient passés en langue française ; toutes les réponses, faites à leurs plaintes et demandes, toutes les poursuites, notifications, décisions, arrêtés, jugements et toutes les pièces concernant l'administration et la justice, étaient rédigés dans une langue tout-à-fait étrangère à la majeure partie des Alsaciens. ${ }^{659}$ Again, the emphasis on written documents- those 'rédigés dans une langue tout-à-fait étrangère' demonstrates the dominance of the written over the oral in contemporary formulations of language policy, particularly in relation to the legal system. It is also significant that this resistance to the linguistic unification of the legal system originated in Alsace, the one part of France where a large linguistic minority spoke a language with a clear tradition of 'high' literate use.

As the borders of France expanded during the Revolutionary and Napoleonic wars, even larger groups of German, Italian, Flemish and eventually Dutch speakers were drawn into the French state. Initially, there seems to have been some ambivalence towards the issue of language in these territories, although the legal document remained the principle site of concern. After the installation of the tribubal de cassation in Trier in November 1799, it quickly became clear that language would become a major issue for the monolingual Frenchmen that had been exported across the Rhine to staff this court. The vast majority of documentation passed up from the local courts- even the judgements and appeal requests- were written in German. This was a problem exacerbated, in the eyes of Barris, the French president of the tribunal, by the irregular orthographic conventions of the German used in the legal documentation of the region. As Barris wrote in a letter to the Minister of Justice, 'nous sommes placés dans un pays qui n'est point encore français, où fort peu de monde parle et écrit la langue français, et où la langue allemande se parle et s'écrit d'une manière très

${ }^{659}$ A. Ulric, 'Discours prononcé dans la séance allemande des amis de la constitution de Strasbourg' in de Certeau et. Al Une Politique de la langue p.304 
différente dans les différentes contrées qui composent les quatre depts. [sic.]' ${ }^{660}$ For Barris, therefore, this was a question both of the selection of the language of legal documentation and of the accuracy of the language used.

Barris proposed something of a compromise to solve the linguistic issue. A sworn translator was appointed to the court and charged with providing French versions of the documentation for the Francophone judges to consult. Even this measure, which fell a long way short of requiring a French language legal system, was problematic, for it was unclear who should pay for the work of the translator. Barris suggested that the translation of the legal documents to which cases related should be made at the expense of the legal system : 'Quant aux actes servant de base à l'action, je ne doute pas que la traduction n'en doivent être faite par ordre du tribunal par un interprète traducteur assermenté, qui devra être payé par le receveur de leur réqet. [sic.]. ${ }^{\prime 61}$ However, Barris felt payment for the petitions appealing judgements made specifically to the court, in contrast to the documentation produced by other legal bodies, was a more difficult matter to settle. In principle, he argued, these 'requêtes ou mémoires, c'est le fait de l'ouvrage des parties, et conséquemment la traduction n'en peut pas être aux frais de la république'. ${ }^{662}$ Yet he also recognised that requiring parties to pay for the translation of documents would be a controversial measure. As he wrote, 'dans ce pays qui n'est pas réunis, où la loi n’a point obligé les citoyens à quitter leur langue naturelle pour parler et écrire la langue d'un pays auquel ils sont encore étrangers, pouvons-nous ordonne qu'il ne sera écrit et parlé chez nous qu'en français ?'663 In other words, requiring litigants to foot the bill for translation when they plead before what was then the highest court in the region would be viewed, Barris feared, as tantamount to establishing French as the official language of the legal system.

\footnotetext{
${ }^{660}$ An BB5 256 (Trèves) Barris, président du tribunal de cassation de Trêves, au Ministre de la justice, 6 frimaire an VIII (27 Nov. 1799)

${ }^{661}$ An BB5 256 (Trèves) Barris au Ministre de la justice, 6 frimaire an VIII (27 Nov. 1799)

${ }^{662}$ An BB5 256 (Trèves) Barris au Ministre de la justice, 6 frimaire an VIII (27 Nov. 1799)

${ }^{663}$ An BB5 256 (Cour de Trèves) Barris au Ministre de la Justice, 6 frimaire an VIII (27 Nov. 1799)
} 
Sentiments within legal circles were apparently so elevated surrounding this issue that a tussle emerged between Paris and the tribunal de cassation over who should make the final decision. Barris attempted to pass responsibility for the decision to the centre, arguing that the court had no authority to determine the language of legal practice; 'c'est une mesure qui tient du legislatif [...] c'est au gouvernement à tracer au tribunal et aux citoyens, par un arrêté particulier, ce qui doit être fait à cet égard'. ${ }^{664}$ The issue encumbered the functioning of the court to such a degree that, just nine days after his initial missive on the subject, Barris felt compelled to write to the minister again, claiming that 'il est urgent, citoyen ministre, que vous veuillez vous expliquer sur les réflexions que je vous ai présentés relativement à nos procédures allemandes. Les jugements même sont presque toujours rédigés en allemand' ${ }^{665}$ When the Minister of Justice did respond, it was simply to instruct the court to follow the regulations for the other tribunals of the region, regulations laid down in germinal of the year VI by Rudler, the then commissaire du gouvernement in the French Rhineland. ${ }^{666}$ However, it seems that these regulations had been ignored, or forgotten, for in his next letter, Barris wrote that no such regulations were in force in the region ; 'je vous observerai qu'il n’y à cet égard dans ces contrées, ni législation, ni règles, ni formes dans les tribunaux et c'est peut-être un mal d'où peuvent naître bien des abus' ${ }^{667}$ Barris therefore presented the minister with a copy of the decree taken by the tribunal on the subject, and asked him to approve the measures it contained. This decree broadly followed the suggestions Barris had made in his first letter on the subject. Any moyens de cassation (the outline of the legal justification for appeal) not presented in French would not be considered, with the case decided simply on the accompanying legal documentation. The cost of translating these pieces would be met by the plaintiff only if their appeal was unsuccessful. ${ }^{668}$ This was, Barris hoped, a workable compromise; 'il

\footnotetext{
${ }^{664}$ An BB5 256 (Trèves) Barris au Ministre de la Justice, 6 frimaire an VIII (27 Nov. 1799)

${ }^{665}$ An BB5 256 (Trèves) Barris au Ministre de la Justice, 15 frimaire an VIII (6 December 1799)

${ }^{666}$ An BB5 256 (Trèves) Ministre de la Justice au Barris, 18 frimaire an VIII (9 December 1799)

${ }^{667}$ An BB5 256 (Trèves) Barris au Ministre de la Justice, 28 frimaire an VIII (19 December 1799) ; It is possible these measures were simply overlooked; Rudler once issued no fewer than 625 decrees in a single day; Rowe From Reich to State p.59

${ }^{668}$ An BB5 256 (Trèves) Arrêté du tribunal de cassation de Trèves, 27 frimaire an VIII (18 December 1799)
} 
nous a paru concilier l'intérêt des partis et l'intérêt de la république sous les formes nécessaire pour que les jugements soyent [sic.] rendus en parfaite connoissance [sic.] de cause' ${ }^{669}$

That Barris was so keen to tread a conciliatory line underscored the symbolic importance of enshrining French as an official language, but was also a reflection of the real practical impact such a move would have on the legal systems of the annexed territories. This would become clear over the course of the next decade as territory was annexed to the Empire and French language policy in relation to the legal system hardened. The four departments of the left bank of the Rhine were formally annexed to France following the treaty of Lunéville in February 1801, and Paris now imposed linguistic uniformity in place of the conciliatory approach that Barris had pursued. On the 24 prairial of the year XI (13 June 1803), Napoleon decreed that all public acts in the Rhineland, in Belgium in Piedmont, and 'dans les autres où l'usage de dresser les actes dans la langue de ces pays' would, by June of 1804 , be written in French. ${ }^{670}$ The measures introduced by Barris had affected only those coming before the tribunal de cassation, now the language policy of the French state was applied to even the most mundane and habitual interactions with the legal profession. The notarial office, probably the most frequent site of interaction between the legal system and the wider population, was not spared, with the acts drawn up there now written in French or accompanied by a French translation. ${ }^{671}$ The only exception was for private documents. Contracts of sale, testaments and the like that were not drawn up by a notary, but rather 'sous seing privé', could still be written 'dans l'idiome du pays'. Yet even here, French was to dominate. The enregistrement of such acts, the officially recognised date of a document, was crucial, for it often served to establish the anteriority, and therefore validity, of claims on property in disputes over ventes, partages or other transactions. Documents presented for this important legal formality had to be accompanied by a version in

\footnotetext{
${ }^{669}$ An BB5 256 (Trèves) Barris au Ministre de la Justice, 28 frimaire an VIII (19 December 1799)

670 Bulletin des lois (1803) no. 292

${ }^{671}$ Under Napoleonic reforms to the profession, the appointment of a notaire rested ultimately in the gift of the government. While in practice decisions tended to follow the recommendations of the chambre des notaires they were regarded as public functionaries and their acts as actes publics; Woloch The New Regime p.345
} 
French, translated by a sworn court interpreter at the expense of the parties themselves. In short, the measures transformed the creation of the administrative and legal documents which governed society in the départements réunis.

These measures were explicitly concerned with the regulation of language choice in a specific context; the production of legal documentation. They would also become the model applied to the next wave of annexed territories as they were incorporated into the French state. Progress, however, was not straightforward or uniform. Like the courts of Piedmont, Belgium and the Rhineland, the legal establishment in Liguria was initially given a year to transition to the French language, following the annexation of the territory in June 1805. However, it proved far more difficult to impose French on the legal institutions of Liguria, and the efforts were beset by multiple delays. As the deadline drew nearer it became obvious that this target would be missed, and the minister of the interior wrote to Régnier, the minister of justice since 1802 , outlining the need to postpone the measure.$^{672}$ Régnier was already resigned to this, and on the $20^{\text {th }}$ of June a decree accorded an additional delay for the area. Interestingly, the length of the delay varied in relation to the apparent readiness of these areas to conform to the new linguistic requirements. Genoa was given six months, Parma and Piacenza and Liguria, including the department of San Remo now attached to the formerly Piedmontese Alpes-Maritimes, got eight, except for the seats of the prefectures and sub-prefectures of the departments of the Appenins and Montenotte, which were given a whole year, until the $1^{\text {st }}$ July 1807 . This was not, however, the end of the issue, and three further delays were granted, with the result that French did not become the official language of the legal system in the region until the start of $1809 .{ }^{673}$

\footnotetext{
${ }^{672}$ BnF Naf 5910 Ministre de la Justice au Ministre de l'Intérieur, 14 Jun. 1806. Presumably this letter, written as the Coqueberts were embarking on their linguistic enquiry, was passed to them as evidence, and has thus remained with their papers.

${ }^{673}$ Decrees of $23^{\text {rd }}$ April 1807, $11^{\text {th }}$ May 1807 and $4^{\text {th }}$ Mars 1808 - See Bulletin des Lois $(1807-8)$ nos. 144,146 , 184
} 
Liguria, then, proved tricky for the French state to digest, at least in linguistic terms. Trickier, that is, than the previous round of annexations in Belgium, Piedmont and the Rhineland, where only foresters required longer than a year to adapt to French. ${ }^{674}$ In contrast, the legal system of Liguria was granted two and a half years, and even after this period the results were somewhat patchy. As late as April 1809, candidates for judicial posts in the region were flagging their knowledge of Italian as a compelling justification for their appointment, not only to facilitate oral communication, but because so many public acts continued to be drafted in the language. ${ }^{675}$

The difficulties encountered in Liguria seem to have informed the way the French approached later annexations. The authorities in Paris, rather than attempting to create an entirely Francophone legal system, sought instead to establish the kind of bilingual courts that existed de facto in other places where standardized languages other than French were used. This was first tried in Tuscany following the annexation of the region in December 1808. A decree passed on the 9th April 1809 noted that 'les peuples de nos départemens de la Toscane sont, de tous les peuples de l'ancienne italie, ceux qui parlent le dialecte italien le plus parfait, et qu'il importe à la gloire de notre Empire et à celle des lettre que cette langue élégante et féconde se transmette dans toute sa pureté' ${ }^{676}$ In recognition of the perceived purity of the Tuscan dialect, provisions were made to support literary production and 'la langue italienne pourra être employée en Toscane, concurremment avec la langue française, dans les tribunaux, dans les actes passés devant notaires et dans les écritures privées' ${ }^{677}$ In October 1810, a decree created bilingual courts allowing the use of Dutch concurrently with French in all but two of the departments formed from the Kingdom of Holland. The exceptions- the Bouches du Rhin and the Bouches de l'Éscaut, presumably because of their position as the closest territory to the existing Belgian departments, were initially given until the end of 1813 to transition to a Francophone legal system. At the end of November 1810 a decree

\footnotetext{
674 Journal de l'empire, 8 Jan.1806 p.2

${ }^{675}$ An BB5 296 (Organisation judiciaire- Gênes) Piossasco, président de la cour d'appel de Turin au Ministre de la Justice, 4 April 1809

676 Bulletin des lois (1808) no.222

${ }^{677}$ Bulletin des lois (1808) no.222
} 
prolonged the deadline indefinitely. ${ }^{678}$ When the Swiss canton of the Valais was annexed as the department of Simplon German was permitted in the courts, as it was in the Hanseatic departments, and both German and Italian were allowed in the courts established in the Illyrian provinces in September $1811 .{ }^{679}$ Finally, in December 1812 , a decree was issued allowing the all-important enregistrement to take place without a French translation in the departments where the 'langue du pays' was permitted in the tribunals, effectively giving German, Dutch and Italian parity with French within the legal system in these areas. ${ }^{680}$

This final measure meant that, by the end of 1812, the departments of the Empire could be arranged into three camps, as evident in Figure 12. The departments of 'Old France' were largely unaffected by the Napoleonic regime. Certainly, the hopes of a German language legal system stirred up in Alsace during the Revolution were dashed, but by and large French was the language of written legal practice before 1789 , and with regard to language practice within the legal system continued much as under the ancien régime. The legal elites of the departments of Belgium, the Rhineland, Liguria and Piedmont, in contrast, experienced a sharp linguistic jolt, as the Napoleonic regime sought to impose French on the legal system. Finally, the most geographically distant territories annexed to the Empire, which were also incorporated towards the end of the period of French expansionism in Europe, were granted a degree of latitude in relation to linguistic practice within the context of the legal system. This was, however, more of a tactical retreat than a wholesale surrender. Only in Tuscany and the Illyrian provinces did the French make any real concessions to the local language. In the German and Dutch-speaking areas of the Empire, leniency in the form of a bilingual legal system was accompanied by the appointment of French language teachers, and the prohibition of non-Francophone journals. In short, a desire to establish the empire of French over the written word remained throughout the Napoleonic period.

\footnotetext{
${ }^{678}$ Bulletin des lois (1810) no.329

${ }^{679}$ Bulletin des lois (1811) no.381

${ }^{680}$ Bulletin des lois (1812) no.459
} 


\section{The Spoken Word before the Law: The Justices of the Peace and the Accommodation of Linguistic}

Difference

French language policy under Napoleon, therefore, was oriented primarily towards the written word. Yet while the Napoleonic state sought constantly to control the language in which legal documents were to be drafted, the myriad occasions provided by the French legal model were far less stringently policed. These communicative occasions varied in formality. Some legal contexts saw the rigorous policing of some aspects of spoken linguistic production. The public trial, for example, unquestionably the most significant procedural innovation of the Revolution, was a context in which communicative practices were strictly governed. This control was not only exerted through conventional pressures (the formality of the occasion determining register, for example), but also by the president of the tribunal, who, following trial procedure, might determine things such as who spoke when, or the appropriateness of a given statement. Despite this, the language in which such communication should take place was never unambiguously determined, and what resulted was a patchwork of different practices across the Empire and across different contexts. For this reason, the institutions of the French legal system tended to accommodate and reflect local linguistic realities, even as the officials who worked in them had to come to terms with writing in French.

These ambiguities were experienced in even the most quotidian encounters between the public and the legal system- those taking place in the notary's office. As we have seen, the notarised documents had to be redacted in French, though nothing prevented the contents of the notarial act being dictated in another language and translated by the notary. Indeed, this practice was explicitly endorsed by the minister of justice in 1805 , in response to a query from the chamber of notaries in Brussels, and reaffirmed by a decision of the cour de cassation in Paris in $1807 .{ }^{681}$ Essentially, uncertainty had emerged because the requirement laid down by the Code Napoleon that all testaments be written 'tel qu'il lui est dicté' seemed to contradict the decrees establishing French as

${ }^{681}$ Massé, Le parfait notaire pp.56-7 ; Merlin, Répertoire universel vol. 6 p.621 
the language of notarial acts. ${ }^{682}$ When, in 1805 , the wife of a Rhenish merchant died and left her estate to another inheritor, the merchant challenged his deceased wife's testament on the basis that the notary had written in French even though she had dictated the terms in German, and that consequently the notary had not transcribed her testament 'tel qu'il lui est dicté'. The cour de cassation threw out the appeal, arguing that since notaries were obliged to draft their acts in French, their validity could not be challenged on the basis of the language in which they were written, and thus defined in practice a clear demarcation between the formal written linguistic production of the notary and the verbal exchange upon which it was based. ${ }^{683}$

The divide between written and spoken linguistic production in legal contexts was evident in practices of the other legal institution with the greatest relevance to the everyday life of the general population, the juge de paix. The juge de paix was, of course, expected to produce his procèsverbaux in French. However, there were no constraints on the language used in the proceedings and arbitrations overseen by the judge. Again, the division between written and spoken linguistic production was clear. This distinction was particularly evident in the evaluation of candidates for the position of greffier du juge de paix. In the appointment of legal officials, especially in relatively low key positions like greffier, the government relied heavily on the local knowledge of the procureur impériale and président of the regional appeal court, who in turn sought the opinion of their counterparts in the civil tribunals located in each arrondissement. These reports were collated by the Ministry of Justice, who would then present a list of three candidates ranked in order of preference to the Emperor, who would make the final decision. The lists of candidates for the place of greffier to the juge de paix provide a telling insight into the importance of language in the

\footnotetext{
682 Merlin, Répertoire universel vol. 6 p.621

${ }^{683}$ Merlin, Répertoire universel vol. 6 p.664 ; Massé, Le Parfait Notaire p.56. Confusingly, although both authors refer to a decision on this case taken by the cour de cassation on the $4^{\text {th }}$ may 1807 , and reference the Bulletin des arrêts of the court, no record appears either amongst the decrees for that date, or at the page reference given by Massé; Bulletin des arrêts de la cour de cassation en matière civile vol.9 no.4 (1807) pp.1517; Ibid. vol.9 no.5 pp.229-30. Nevertheless, the case is cited by various dictionaries of jurisprudence, for example that of Jean-Baptiste Sirey, who was himself a lawyer at the cour de cassation; J.-B. Sirey Tableau alphabétique des lois et arrêts (Paris, 1811) p.794
} 
selection of candidates, and therefore in the practices of the juge de paix as an institution. Since the greffier was charged with drafting the procès-verbaux of the procedures of the juge de paix, it was essential that he could write French, something that frequently became problematic in the départements réunis. This was made clear by evaluation of one candidate from the Piedmontese department of the Stura, whose favourable report read that 'il connait la langue française:

circonstance aussi essentielle que singulière et rare dans cette division' ${ }^{684}$ The ideal candidate spoke the local tongue and wrote French. Thus a positive report on one candidate from the department of the Forêts, which was formed from territory in present day Belgium, Germany and Luxembourg, made clear 'que c'est un excellent sujet, que sa conduite est irréprochable, qu'il connait les langues française et allemande'. ${ }^{685}$ Similiarly, Luis Jassin was considered a strong candidate for a place in the Flemish-speaking Belgian department of the Escaut, in part because of his lingusitic capacities; 'Il a les connaissances nécessaires et possède les langues française et flamande'. ${ }^{686}$

The preference for bilingual greffiers reflected not only the requirements of a French language legal bureaucracy, but also the realities of working in communities where French was not widely spoken. When Louis Victor Gengoule was proposed for the post of greffier in the Dutch department of the Deux Nethes, the author of the report cautioned, 'J'ignore s'il sait assez la langue du pays pour pouvoir se tirer d'affaires dans un canton rural dont le juge de paix ne la sait pas' ${ }^{687}$ Significantly, this hesitation reveals the assumptions held in Paris about the linguistic practices of the juges de paix and their greffiers. They were to redact their documents in French, but the efficacy of the institution rested on the ability to communicate orally with the inhabitants of a canton in their own language. If the judge himself could not fulfil this function then it was imperative that his greffier would be able to step into the breach. This assumption also held for non French-speaking areas of Old France. In lower Brittany, for example, knowledge of Breton was frequently included

\footnotetext{
${ }^{684}$ An BB8 48 (Rapports sur les candidats aux places de greffiers de justice de paix et de tribunaux de police, An XII- An XIV) Liste des candidats pour la place de greffier du canton de St. Damien, Stura ${ }^{685}$ An BB8 48 Liste des candidats pour la place de greffier du canton de Remich, Forets ${ }^{686}$ An BB8 48Liste des candidats pour la place de greffier du canton de Assenede, Escaut ${ }^{687}$ An BB8 48 Liste des candidats pour la place de greffier du canton de Contich, Deux Nethes
} 
amongst the positive qualities of a candidate. Jean-Marie Cruzel from Finistère, for example, was noted as 'gendre du Juge du Paix de Landernau, [...] sachant l'idiome Breton ; joignant la probité à la moralité. Parait le plus propre à remplir la place'. ${ }^{688}$ This was also the case in Bayonne, where Jacques Detcheparre was well thought of as a candidate, since 'il est très versé dans la partie judre. et possède l'avantage précieux de parler l'idiôme Basque qui est le langage de plus de la moitié des justiciables du Canton'. ${ }^{689}$

The expectation that the juge de paix or his greffier should be able to communicate with his justiciables even as written documentation was produced in French placed the burden of French language policy on legal officials, rather than the general population. In non French-speaking regions, such as the Rhineland, this made the juge de paix a popular institution for resolving legal disputes. ${ }^{690}$ The significance of this informal bilingualism was underscored by the appointment of a greffier named Raoul to the canton of Pont-Scroff in the Breton department of Morbihan. Raoul's candidature was supported by several pieces sent by the president and the procureur of the local tribunal, including 'une lettre du juge de paix en faveur du Sr. Raoul et un certificat souscrit par le Président et les Maires des Six communes composant le canton, qui tous en disent beaucoup de bien et attestent qu'il connait l'idiome Breton' ${ }^{691}$ The intervention of the mayors of the canton demonstrates how the distinction between written and oral language within the French judicial model allowed local administrators to mediate between Francophone centre and non-Francophone locality, at least at the level of the juges de paix.

Curiously, while language appears frequently in the evaluations of candidates from the pays réunis where foreign languages were spoken, and from areas like Britany and the Basque country, where languages that were completely unrelated to French were spoken, reports from the

\footnotetext{
${ }^{688}$ An BB8 101 (Nominations de greffiers, 1801-1814. Finistère- Hte. Garonne) Liste des candidats pour la place de Greffier de la Justice de Paix du Canton de Ploudin. 31 Oct 1811

${ }^{689}$ An BB8 48 Liste des candidats pour la place de greffier du canton de Bayonne, Basses Pyrénées

${ }^{690}$ Rowe, From Reich to State p.106

${ }^{691}$ An BB8 48 Liste des candidats pour la place de greffier du canton de Pont-Scorff, Morbihan
} 
Romance-speaking bulk of Old France remain entirely silent on the issue. In the South, selection appears to have focused on literacy rather than linguistic difference. Thus when a position as greffier for the Juge de Paix for the canton of Sainte Maries, near Arles in the Bouches du Rhône, became vacant, the successful candidate was chosen not for his grasp of French in a Provençal speaking region, but for his literacy, with the local procureur writing that 'Il résulte des renseignemens que j'ai pris, qu'il y a dans ce canton bien peu de sujets en état de remplir cette place, je n'ai trouvé que le Sr. Brunnel qui soit digne d'être présenté. La population n'est composé que de pêcheurs ou de cultivateurs illettrés'. ${ }^{692}$

It is unclear why the issue of language, so prominent in the discussion over appointments of greffiers in the non-Francophone départements réunis and the Basque and Breton-speaking areas of western France, should have disappeared in relation to Romance-speaking France. However, as the struggles of the procureur to find a capable subject in Sainte Maries demonstrates, most justices of the peace and their greffiers were drawn from the area in which they functioned. It is likely that as local figures themselves they were, across the Empire, capable of the kind of informal bilingual practice described in the départements réunis, in Brittany and in the Basque country. It was in the higher courts, where legal officials were more likely to come from outside the local community, that the ambiguities and tensions of the cultural mediation carried out by legal professions were most clearly visible.

\section{Accommodating Linguistic Diversity in the Higher Courts}

While the oral, relatively informal, process of arbitration overseen by the juge de paix, leant itself easily to this kind of flexibility, the legal processes of the higher courts were, in principle at least, governed by a more formalised code, in which the language of spoken communication was more strictly regulated. In his dictionary of jurisprudence, Merlin claimed that Villers-Cotterêts should be taken as a guide not only for written documents, but for legal proceedings, writing of the

${ }^{692}$ An BB8 48 Liste des candidats pour la place de greffier du canton de St. Maries, Bouches du Rhône 
ordinance that 'les procédures en langage vulgaire du pays furent donc absolument abolies' ${ }^{693}$ This created a practical difficulty concerning the management of trials involving individuals who spoke no French, or as Merlin posed the question, 'comment en usait-on, non-seulement à l'égard des étrangers, mais même à l'égard des nationaux qui n'entendaient pas l'idiome des villes?'694 In these situations, where a witness or accused did not understand the language in which they were to be questioned, or when the accused did not understand the language of a witness, a sworn interpreter was to be appointed by the president of the court, with the verdict considered unsafe if he failed to do so. ${ }^{695}$

In practice, this apparently clear procedural form produced a variety of different practices. This can be seen in the commentary provided by the judges who sat in the higher courts themselves in one of the most important sources on the judicial culture and practice of the period, the Observations des tribunaux sur le projet du code criminel de I'an XI. These observations were written in response to a proposed criminal code, which was published in 1804 and would, after sustained discussion and revision, become the basis of the code of criminal inquiry in 1808 and the code of criminal procedure in $1810 .{ }^{696}$ Twenty-two of the appeal courts of the Empire, and seventy-six of the then 106 departmental criminal courts furnished reflections on this project, which were published in eight volumes in 1804, providing an invaluable snapshot into the linguistic practices within the legal system of the period. ${ }^{697}$ Numerous responses published in these observations criticise various aspects of the proposed criminal code because they would make the informal accommodation of linguistic diversity more complicated. The responses of the criminal and appeal courts reveal three

\footnotetext{
${ }^{693}$ Merlin, Répertoire universel xv, p.485

694 Ibid., xv, p.485

695 Ibid., xv, pp.485-7

${ }^{696}$ R. Martinage, 'L'Opinion des tribunaux de départements rattachés sur la justice Française d'après leurs observations sur le projet de code criminel de l'an $\mathrm{XI}^{\prime}$, Influence du modèle judiciaire français en Europe p.277 ; Projet du code criminel, avec les observations des rédacteurs, celle du tribunal de cassation et le compte-rendu par le Grande-Juge (Paris, 1804)

${ }^{697}$ Observations des tribunaux d'appel sur le projet de code criminel (2 vols., Paris, 1804); Observations des tribunaux criminels sur le projet de code criminel (6 vols., Paris, 1804) Katy Gawelik has catalogued the subjects treated within these commentaries, greatly facilitating their consultation. K. Gawelik Sources de la codification pénale à la lumière des observations des tribunaux sur le projet de Code criminel de I'an IX (Lille, 2008)
} 
key points of linguistic tension within the French judicial model: the linguistic capacities of the judge and consequently his ability to direct proceedings; the role of oral translation and interpreters; and finally the composition and conduct of juries.

The proposed reorganisation of the criminal courts such that the judges presiding over proceedings would be rotated around the courts of the Empire on a yearly basis, was singled out by many observers as problematic, precisely because these outsiders would be unable to communicate in the local language. ${ }^{698}$ This was clear from the response of the tribunal of the Gers, which claimed that 'la connaissance de l'idiome local, manquera à un préteur annuellement renouvelé et étranger au département', a grave problem since this knowledge was 'd'une absolue nécessité pour la direction des débats'. ${ }^{699}$ The problem of mutual comprehension took on a special importance within the courtroom, because misunderstanding the testimony of a witness could have such an impact on the lives of those involved in a trial. As the tribunal of the Limousin department of the Haute Vienne observed, an outsider would struggle to follow the deliberations of the court because 'le plus souvent il ne comprendra pas ce que lui diront l'accusé et les témoins; ceux-ci ne comprendront pas eux-mêmes les questions qu'il leur fera : à chaque pas il rencontrera des entraves qui le fatigueront, qui nuiront à la justification de l'accusé, qui atténueront les preuves de sa culpabilité. The potential for confusion and misinterpretation introduced by a judge from outside the department could only be to the detriment of the administration of justice, since 'il est essentiel, surtout en matière criminelle, que le magistrat chargé de recueillir toutes les preuves à charge et à décharge, en saisisse le véritable sens' ${ }^{700}$

Objections to the travelling magistrates were joined by concerns over a second area of linguistic tension within French judicial practice, the role of oral translators within the courtroom.

\footnotetext{
698 Projet du code criminel p.161

699 'Observations du tribunal criminel du Gers', Observations des tribunaux criminels iii, p.2

700 'Observations du tribunal criminel de la Haute Vienne', Observations des tribunaux criminels vi, p.9
} 
The appeal court of Agen in the Gascon department of the Lot et Garonne criticized the rotation of judges because the practice could lead to a greater dependence on translators, writing that if the functionary was placed 'dans un département éloigné de celui où il remplit ses fonctions, il faudra un interprète pour expliquer les réponses, les faits justificatifs de l'accusé' ${ }^{701}$ This criticism reflected a general unease about the place of translators within the courtroom, unease that was in turn fed by what were felt to be the particular exigencies of communication within a legal setting. As the criminal tribunal of the Lys observed, 'Il est impossible que l'interprète le plus habile puisse toujours suffire dans l'instruction d'une procédure criminelle ; l'expression d'un témoin, dans sa langue naturelle, n'est pas toujours bien saisie par l'interprète'. Again, this was felt especially inimical to the effective administration of justice, for the fairly obvious reason that the statement of a witness or accused 'est souvent d'un tel poids, quand elle est bien, saisie par le juge, qu'elle peut faire changer toute l'affaire de face, soit pour la conviction, soit pour l'absolution d'un accusé'. ${ }^{702}$ The same sentiment was expressed by the tribunal of the Basses-Alpes, which observed that 'la procédure par interprète n'est pas d'une justice exacte ; on ne doit l'employer que lorsqu'il n'y a pas d'autres moyen de rendre la justice' ${ }^{703}$ As the tribunal observed of the prospect of rotating magistrates overseeing criminal trials across the Empire, 'alors la procédure par interprète, qui est toujours, et chez tous les peuples un cas d'exception, deviendrait la procédure ordinaire pour une partie des départemens de la République'. ${ }^{704}$ In this instance, patois and the other standardized languages of the Empire posed similar issues.

The projected criminal code sought to regularise the use of interpreters, specifically proscribing the practice of selecting translators from amongst the witnesses or jury. Many of the responses from the southern regions of France claimed this would be a particular issue because the

\footnotetext{
701 'Observations du tribunal d'appel d'Agen', Observations des tribunaux d'appel sur le projet du code criminel i, p.30

702 'Observations du tribunal criminel de la Lys ', Observations des tribunaux criminels iii, pp.8-9

703 'Observations du tribunal criminel des Basses Alpes', Observations des tribunaux criminels i, p.8

704 'Observations du tribunal criminel des Basses Alpes', Observations des tribunaux criminels i, p.8
} 
local language changed so quickly from one settlement to the other. The tribunal of the Ain, for example, claimed that in the department, 'il regnent 5 ou 6 idiomes ou patois différens qui ne sont bien compris que par les habitans de ces localités où ils sont en usage'. For this reason, excluding members of the jury or other witnesses from performing the role of translator would be impractical, and would expose 'le cours de la justice à être interrompu au milieu de débats d'une affaire, parce que très souvent on ne trouverait pas d'autre interprête [sic.] dans le lieu où siège le tribunal'. ${ }^{705}$ The tribunal of the Haute-Vienne had also cited the extreme variability of the spoken language of the region as a strong argument against the idea of ambulatory magistrates, writing 'que des citoyens domiciliés à l'extrémité d'un département, souvent ne comprennent pas l'idiome vulgaire en usage à l'extrémité opposée du même département'. This variation could even throw a local official ; 'nous avons vu des juges, quoique natifs du département où ils exerçaient leurs fonctions, et y ayant toujours vécus, être quelquefois embarrassés dans l'instruction de la procédure'. This being the case, the tribunal argued, how could an outsider ever hope to supervise a trial effectively, 'surtout dans les départemens méridionaux, où l'idiome change d'une ville à l'autre, où le peuple est très-peu familier avec la langue française, où il ne parle et n'entend que la langue vulgaire du pays' ? ${ }^{706}$ Objections to the practice of formal translation, and to the rotation of judges, both seem therefore to have turned on the same desire to avoid introducing a greater linguistic distance between the judge and those he judged, a goal many members of the judiciary evidently felt could be best achieved through the maintenance of an informal process of linguistic negotiation within the courtroom. Rather than a foreign judge and a sworn interpreter, the ideal was for a magistrate familiar with the population and region over which he exercised authority to informally seek clarification from individuals present.

The third and final point of linguistic tension raised by the members of the criminal and appeal courts was the composition and conduct of juries. While moving judges from court to court,

705 'Observations du tribunal criminel de l'Ain', Observations des tribunaux criminels i, p.34

706 'Observations du tribunal criminel de la Haute Vienne', Observations des tribunaux criminels vi, p.9 
like the tighter regulation of court interpreters, was an issue broached by members of the judiciary from across the Empire, juries were raised as an issue most frequently in the départements réunis. In the south of France it was simply assumed that the members of the jury would broadly speak the same language as the witnesses and accused. When the members of the tribunal of the Aude, for example, criticized the rotation of judges, they included the members of the jury in the list of those a French-speaking magistrate would struggle to communicate with, observing that 'presque tous les accusés, la majeure partie des témoins, souvent même quelques jurés, ne parlent qu'un langage qui lui sera inconnu' ${ }^{707}$ In the Belgian department of the Escaut, by way of contrast, concerns focused not on the ability of the judge to understand the members of the jury, but on the capacity of the members of the jury to follow the trial. The question posed by the members of the tribunal; 'peut-on être juré, ignorant la langue française ?', implies that in the Escaut, the procedure would take place in French, making it problematic to appoint a juror who did not speak the language. ${ }^{708} \mathrm{~A}$ similar concern was evident in the neighbouring department of the Lys. Here problems encountered in the establishment of trial by jury had precipitated the 'exclusions des ex-nobles, des parens d'émigrés, des hommes qui n'entendaient pas la langue française' from the jury lists. ${ }^{709}$ In one respect, the responses on the subject of juries from both Belgium and southern France describe exactly the same situation- namely, that juries, like witnesses and accused, had a tendency to replicate the linguistic profile of the local population from which they were drawn. The lack of Francophone jurors was probably exacerbated by the process of jury selection. Jury service was viewed as an imposition, and wealthier urban candidates were often quick to excuse themselves with the help of a compliant officier de santé..$^{710}$ However, while in the South it seems judges were expected to accommodate this linguistic diversity, the courts of the Belgian departments sought to remove non-French speakers from the jury whenever possible. In this context, the regional languages of France were accommodated to a greater extent than standardized languages like Flemish.

\footnotetext{
707 'Observations du tribunal de l'Aude', Observations des tribunaux criminels i, p.9

708 'Observations du tribunal de l'Escaut', Observations des tribunaux criminels ii, p.19

709 'Observations du tribunal de la Lys', Observations des tribunaux criminels iv, p.2

${ }^{710}$ Woloch, New Regime pp.374-5
} 
An indication of the geography of these practices is given in Figure 13, which shows the distribution of the criminal or appeal courts that cited language as a specific issue in their observations on the proposed criminal code. Many of these responses expressed concerns in a general way, about the how one or another aspect of the code would lead to a formalized, Francophone judicial procedure. The response from the Rhenish department of the Roer, criticized the plan to rotate judges around the Empire for much the same reasons as the courts of southern France, with the members of the tribunal demanding rhetorically whether these judges, who 'ne connaissent pas les localités, les usages, les moeurs et les idiomes reçus dans les départemens dont ils doivent présider les tribunaux criminels, comment pourront-ils donner les développemens nécessaires aux débats ?'. ${ }^{711}$ Such a statement is fairly limited in what it can tell the historian about the specific linguistic practices within a particular tribunal. However, it is striking that concerns over measures that might lead to a formalized diglossia- that is over the appointment of migratory judges requiring translators to communicate with those appearing before the court, or the hardening of regulations surrounding the use of translators- emerge almost exclusively from the Occitan-speaking South, the Flemish-speaking Belgian departments and the German-speaking Rhenish departments. Concerns were focused on those parts of France contemporaries thought to be linguistically diverse. Thus the response from the Manche, a department the Duruy enquiry found to be entirely Frenchspeaking in 1864 , worried not about the introduction of new judges to Normandy, but to other parts of France where language was an issue; 'I'homme qui n'a vécu qu'à Paris' would be able to 'soutenir des dialogues nécessaires avec les Bas-Bretons, les Picards, les Auvergnats, les Savoyards' ${ }^{712}$ As such concerns demonstrate, the French legal model had a strong linguistic dimension and applying it brought linguistic tensions to the fore both where other standardized languages were spoken and where dialects were in use.

\footnotetext{
711 'Observations du tribunal de la Roer', Observations des tribunaux criminels vi, p.5 712 Weber, Peasants into Frenchmen p.499; 'Observations du tribunal criminel de la Manche', Observations des tribunaux criminels iv, pp.63-4
} 
As all this suggests, the ostensibly straightforward linguistic regulation of the trial procedure within the French legal system- that of a French language courtroom supplemented with interpreters where necessary, resulted in a number of different practices across the courtrooms of the French state. In Brittany, the regional parlement sitting in Rennes had long required anyone who did not speak French to have a sworn interpreter appointed to aid them in legal proceedings. This practice continued throughout the nineteenth century, with the court records thus providing an invaluable source for historians of language shift, who, in the absence of sound statistics, have used the proportion of individuals given interpreters as a proxy for rates of French speaking in the broader population. ${ }^{713}$ While the courts in Brittany cleaved assiduously to procedural best practice throughout the nineteenth century, appointing translators for monolingual Breton speakers, the courts across Romance-speaking France did not use sworn interpreters when confronted with speakers of regional languages despite the risk of having their judgements struck down. In Languedoc, for example, researchers have found no trace of Occitan translators, even where slips and stray Occitan words appear to reveal that the spoken language of a particular deposition was not French. ${ }^{714}$ Similarly, in Provence during the Napoleonic period, 26 case files heard at the appeal court of Aix, along with the trial records of the criminal court of Aix between 1802 and 1808 reveal only one instance of an interpreter being sworn in. ${ }^{715}$ This interpreter was not a translator of Provençal, but of Oriental languages, appointed to Jacques Calicopulo, a merchant from the République des sept îles, who unsuccessfully pursued a claim for fraud in at the appeal court of Aix in $1802 .{ }^{716}$ The absence of Occitan interpreters indicates that the process of informal translation by bilingual legal officials that was evident in the practices of the justices of the peace also pertained

\footnotetext{
${ }^{713}$ Broudic, Pratique de la langue bretonne p.59

${ }^{714}$ Y. Castan, 'Les Languedociens du XVIIle siècle et l'obstacle de la langue écrite' in France du nord et France du midi, Actes du $96^{e}$ Congrès national des sociétés savantes Toulouse 1971 (Paris, 1976) pp.73-5

${ }^{715}$ AdBdR 2 U 42 (Procès-verbaux du tribunal criminel d'Aix- An X- An XII) ; 2 U 43 (An XIII- 1808) ; AD B-d-R 2 U 2 (Cour d'appel- dossiers de procédure) Dossiers 838, 839, 840, 841, 844, 850, 860, 1053, 1061, 1063, 1064, $1065,1067,1068,2004,2039,3861,3862,3867,4396,4392,4393,4577,4580,4593$, ${ }^{716}$ AdBdR U 2841 (Dossier de procédure de la cour d'appel d'Aix- Joseph Bonnet prévenu pour escroquerie envers Joseph Callicopulo)
} 
within the higher courts of the south. As Séguin de Pazzis, author of a statistical description of the Vaucluse, wrote 'les Magistrats, surtout les Juges au Criminel, sont dans le cas de l'employer quelquefois, et même doivent en connoître [sic.] la force ou la finesse'.$^{717}$

As the claims of Séguin de Pazzis, and the absence of translators shows, the burdens of managing linguistic diversity in the south of France generally meant that the oral portions of the legal procedure would be conducted in the local language. The observations of the criminal court in 1804 made this unambiguously clear; 'dans la 20e division militaire dont dépend le département du Lot, en général, les débats dans les affaires criminelles se font dans l'idiome patois'. ${ }^{718}$ In the department of the Basses-Alpes, the criminal tribunal observed that 'dans l'instruction et dans les débats, nous sommes obligés de nous servir ordinairement de l'idiome provençal, tant à l'égard des accusés que des témoins'. The tribunal went on to make clear that while civil cases might be treated in French, it would be impossible to direct a criminal case other than in Provençal : 'on peut exiger que les affaires civiles se traitent en français ; mais on ne peut obliger une personne qu'on accuse, ou dont on requiert le témoignage, à parler une langue qu'elle ne connaît point ; il faut nécessairement se prêter à l'idiome qui lui est familière'. ${ }^{719}$ As can be seen in Figure 13, nine of the criminal tribunals of the south of France submitted observations on the new criminal code describing this kind of practice as the norm in their departments. While the presence of Breton language translators indicates that trials in Brittany took place in French, the courts of the Occitan-speaking South pursued a very different policy of conducting trials in the local language. More broadly, it seems that the linguistic practices of the old regime largely persisted within the departments of the interior. In Brittany this meant the continued use of interpreters, whereas in the South this resulted in the persistence of a distinction between oral and written language, whereby the former could take place in patois so long as the latter was done in French.

\footnotetext{
${ }^{717}$ M. Séguin de Pazzis, Mémoire statistique sur le département de Vaucluse (Paris, 1808) p.48

718 'Observations du tribunal criminel du Lot', Observations des tribunaux criminels iv, p.4

719 'Observations du tribunal criminel des Basses-Alpes', Observations des tribunaux criminels vol.1 p.8
} 
In the departments of the interior, the persistence of a distinction between written and oral language and the widespread knowledge of written French amongst the judiciary meant the institutional upheavals of the period left linguistic practices largely untouched. In contrast, the linguistic practices of the legal systems of non-French speaking territories annexed during the Revolutionary and Napoleonic wars were necessarily transformed. While members of the judiciary from across the South objected to the notion that judges could be shipped from other parts of the empire to preside over law courts, this was precisely what happened in many of the annexed departments, with the government keen to export French legal officials because of their knowledge of French law and legal forms. This was especially true for sensitive posts, such as that of public prosecutor, and doubly so in the criminal courts, where the greatest concentrations of French jurists could be found..$^{720}$ Of course, appointing such men made the administration of justice all the more difficult, since they rarely spoke the local language. In 1809, three Frenchmen, Franquen, Maillot and Goubeau, were proposed for the positions of president in the three criminal courts of the Tuscan departments of Arno, Ombronne, and the Méditerannée. The procureur of the appeal court of Florence, wrote to the Minister of Justice, weighing up the advantages of these appointments. The central problem was that they would be unable to conduct procedures in Italian, a crucial task for those presiding over the criminal courts. As he wrote,

il m'a paru que les Présidences des Cours de Justice Criminelle mettant ceux qui les occupant en rapport journalier avec des témoins et des accusés qui n'entendent pas un seul mot de français il était de la plus haute importance de les faire remplir par des Magistrats qui entendissent et parlassent la langue du pays. ${ }^{721}$

The procureur acknowledged that appointing Frenchmen to the position would have the distinct advantage of placing the court in the hands of individuals who possessed a sound understanding of French law and procedure, something one could not expect from a native. However, his letter made clear the recipient would have to speak Italian. The procureur weighed up the alternatives in a way

\footnotetext{
${ }^{720}$ Rowe, Reich to State p.107

${ }^{721}$ AN BB5 391 (Organisation Judiciaire- Arno) Procureur général de la cour d'appel d’Arno au Min. de la J. 19 Mar. 1809. This piece of correspondence was unearthed by Professor Michael Broers, and I thank him for forwarding it to me.
} 
that left only one option for Paris ; 'si d'après ces réflexions VE jugeait que la différence des langues ne dût pas être un obstacle suffisant' ${ }^{\prime 22}$ In this instance the procureur's arguments were effective in winning a concession from Paris on linguistic practice, for none of the three candidates were successful in obtaining these posts. ${ }^{723}$

If linguistic diversity was accommodated in Tuscany, one of the areas where a bilingual court system was permitted, it seems greater efforts were made in other parts of France to shift the language of procedure to French, with varying degrees of success. In his dictionary of jurisprudence, Merlin observed of the courts of Liguria, that 'Il est [...] remarquable que depuis cette époque [1809], tous les actes de procédure, ainsi que les plaidoiries, se font en langue française devant les tribunaux de Gênes'. ${ }^{724}$ Merlin's claim that the plaidoiries, the presentation of the case for the defence, took place in French, would seem to imply the language played a prominent role in the oral proceedings of the law courts. However, this was only accomplished after several years of pressure and delays, as well as the presence of a number of French officials. Indeed, in the Rhineland, French language proceedings seem to have proceeded in fits and starts. In June 1803 it was claimed that in the Rhineland, cases in the tribunals of Mainz and Speyer were heard in French, while the tribunals of Zweibrücken, Kaiserslautern and other towns where French was less widely known worked in German. ${ }^{725}$ Even in apparent success stories like Mainz the use of French was not straightforward for all concerned. In 1810 It was recommended that Bodmann, then vice-president of the tribunal of Mainz, be returned to the role of judge, because 'il est peu familier avec la langue française, il s'explique d'une manière si singulière qu'il amuse le public qui se rend en foule aux audiences pour y rire à ses dépens' ${ }^{726}$ The humiliation of Bodmann would seem to point not only to the prominent role of French in court procedure, but to the difficulties encountered in arriving at and maintaining such a situation.

\footnotetext{
722 AN BB5 391 (Arno) Procureur général de la cour d'appel d'Arno au Min. de la J. 19 Mar. 1809.

${ }^{723}$ Almanach Impérial, pour l'année 1811 (Paris, 1811) pp. 512-8

${ }^{724}$ Merlin, Répertoire universel et raisonné de jurisprudence vii, p.491

725 Journal des débats 11 messidor an XI p.4

${ }^{726}$ AN BB5 256 (Trèves) Liste des candidats pour le tribunal de premier instance séant à Mainz, $18^{\text {th }}$ Aout 1810
} 
Even where French language procedure was apparently entrenched, the kinds of informal translation practices described elsewhere in France were evident. In the Belgian departments of the Lys, the Dyle and the Escaut, all of which were majority Flemish-speaking, it seems that French language procedures were the norm. This was apparent from the exclusion of Flemish speakers from jury lists, and reinforced by the reflections of the tribunal of the Dyle on the use of translators. The observations from this tribunal stated that, 'dans quelques départements où la langue française n'est pas fort répandue, l'on a dû avoir recours à des interprètes pour l'instruction des affaires criminelles'. ${ }^{727}$ This statement would seem to imply that, as in Brittany, the departments of Flemish speaking Belgium followed a pattern of French language procedure supplemented by interpreters. However, the constant recourse to interpreters was seen as problematic, with a move towards the more informal translation practices of southern France deemed preferable- 's'il ne s'agit que d'interpréter la langue ou le jargon local, je ne vois pas la nécessité d'avoir recours au ministère d'un interprète, $[\ldots]$ les greffiers ou les commis-greffiers devraient être charge de traduire le jargon ou la langue locale'. ${ }^{728}$ In the Lys, where non French speakers had also been removed from the lists of jurors, it seems that such informal practices of translation were important in the functioning of the court. The members of this tribunal proudly declared in 1804 that 'dans le département de la Lys, [...] le tribunal criminel est le seul des neuf départements réunis qui a été composé depuis l'an VI, de tous hommes du pays'. ${ }^{729}$ This was especially important, because 'le président d'un tribunal criminel doit parfaitement connaître l'idiome du pays dans laquelle il exerce. [...] L'expression d'un témoin, dans sa langue naturelle, n'est pas toujours bien saisie par l'interprète'. ${ }^{730}$

\section{The Legal Profession between Paris and Province}

The French judicial model, therefore, exercised pressure on the judiciary to administer justice in the French language, although in practice linguistic diversity was accommodated in a

\footnotetext{
727 'Observations du tribunal criminel de la Dyle', Observations des tribunaux criminels ii, p.40

728 Ibid., p.40

729 'Observations du tribunal criminel de la Lys', Observations des tribunaux criminels iv, p.9

730 lbid., p.8
} 
number of different ways. At the level of the juge de paix and the notary there was a clear distinction between the written documentation, which almost everywhere had to be in French, and spoken communication, which could be in whichever language was deemed most appropriate. This distinction blurred inside the courtroom, where the importance of testimony made spoken language a more delicate issue. The consequences of misunderstanding were far greater, and in principle judges were obliged to call on sworn interpreters where necessary. In the départements réunis political pressure and the arrival of French speakers seems to have sparked a movement towards French language proceedings. In practice, a range of less formalized methods of accommodating linguistic diversity were often preferred, from the Occitan deliberations of the South to the endurance of German proceedings in the Rhineland and the informal translation described in Belgium. However, across the range of practice, the legal profession remained a key mediating body between Francophone centre and non-Francophone provinces.

Many members of the judiciary understood their role to include mediation between the strictures of the law laid down by Paris and the interests and culture of the local community. In criticising the project of rotating judges around the courts of the empire the tribunal of the Eure et Loire outlined an ideal of the legal official enmeshed in local culture and society. Appointing a judge to travel across different legal jurisdictions was problematic because 'il sera privé de ses notions locales, si essentielles pour être parfaitement instruit des mœurs, de l'esprit du pays' ${ }^{731}$ Some members of the judiciary explicitly criticised the prevailing Napoleonic vision of the law as a tool for the reform of society. The central legal reform of the period, the Napoleonic code, was based on the idea that good law could be universally applied to the benefit of all. A countervailing body of opinion emerged from the commentaries gathered in the Observations. According to some of the tribunals who provided commentaries, laws should be drafted to suit the character and morality of the population. In the observations of the tribunal of the Lot et Garonne, the members of the tribunal argued that 'les lois criminelles et pénales doivent être essentiellement en rapport avec les mœurs

731 'Observations du tribunal criminel de l'Eure et Loire', Observations des tribunaux criminel ii, p.6 
du peuple pour qui on les fait. [...] Donnez-lui des lois trop dures, elles seront une calamité, elles exciteront la compassion envers le coupable, et leur durée sera courte' ${ }^{732}$ According to the tribunal of the Escaut, 'tous les publicistes enseignent que les lois doivent être en harmonie avec l'étendue du pays, avec le nombre des habitans, avec leurs mœurs et leurs habitudes' ${ }^{733}$

This commitment to accommodating the interests and preferences of local society, of mediating them in the face of the centralizing tendencies of the Napoleonic state, coalesced around the issue of language and the defence of the local legal officials who could speak it. The tribunal of the Lot et Garonne defended the use of Gascon in court, but did so with a curious fusion of local pride and shame. In the first instance, it was the lack of order, the chaos and confusion that rendered a local judge necessary.

Dans ces débats terribles où tout peut être funeste, principalement le dialecte des témoins et des accusés, dialecte dont les acceptions offrent des sens divers de la rive d'un fleuve à la rive opposée, préférez-vous pour le juger un étranger à l'homme du lieu, qui entendra le langage de sa nourrice dans celui des témoins et de l'accusé... ? ${ }^{734}$

Bemoaning the 'gruesome' nature of the deliberations in court and the confusion exacerbated by the intractable linguistic diversity of the participants hardly represents a convincing defence of regional culture, although it did highlight the value of the special knowledge of local officials. This knowledge, passed down by the wet nurse, could never be replicated by an outsider. However, while the members of the tribunal expressed disdain for the chaos unleashed by local particularism, it also expressed scorn for Parisian culture:

On le demande aux auteurs du Projet, s'ils étaient accusés dans une de nos provinces méridionales ou maritimes, dont ils seraient originaires, n'aimeraient-ils pas mieux avoir pour juge un basque, un bas-breton ou gascon, suivant les lieux, qu'un Parisien, avec sa bouche arrondie et ses accens flûtés, qui n'y comprendrait rien $?^{735}$

\footnotetext{
732 'Observations du tribunal criminel du Lot et Garonne', Observations des tribunaux criminels iv, p.1

733 'Observations du tribunal criminel de l'Escaut', Observations des tribunaux criminels ii, pp8-9

734 'Observations du tribunal criminel du Lot et Garonne', Observations des tribunaux criminels iv, p.1

735 lbid., p.9
} 
The sardonic description of the softly spoken Parisian is striking, and there is an unmistakable pride in the notion that a judge from the capital could never cut it in the province. The members of the tribunal identified themselves as intermediaries, disdainful of the raucous trials produced by the regional culture, yet at the same time convinced that their local knowledge marked their value within the legal bureaucracy. The provincial judges presented their local knowledge as expertise vital to the functioning of the legal system, cementing their position within the legal structure.

Equally, the status of legal officials within local communities rested on their ties to central authority, and those that came before them seem to have recognised their position as intermediaries, brokers or outsiders. In many of the comedies and vaudevilles of the cities of the south of France, the judges that featured simply spoke in French, with the local populace confronted by the language every time they interacted with legal institutions. Playwrights used language as a tool of characterisation, with characters enjoying high status, or those who would affect to enjoy high status, marked out by their use of French, while peasants and the popular classes spoke Provençal. ${ }^{736}$ As Auguste Brun observed, judges and other officers of the law are habitually arranged on the French-speaking side in these comedies. Thus in the plays of the Abbé Thobert, Provençalspeaking peasants are translated before French-speaking judges, while in another example cited by Brun, a comedy published in 1785 under the title Le Marché de Marseille, vo lei doues coumaires a French-speaking commissaire steps in to resolve a dispute over alleged tampering with a set of scales between Provençal-speaking market traders. ${ }^{737}$

In other representations of legal officials the practice of informal bilingualism in legal contexts was clear, but the judge was still understood as an outsider. When James Bruyn Andrews published his Essai de grammaire du dialecte mentonnais in 1875 , he illustrated his argument that the dialect spoken in Menton was a transitional language between the Provençal dialects of Niçard

\footnotetext{
${ }^{736}$ A. Brun, La Langue française en Provence, de Louis XIV au Félibrige (Geneva, 1972) pp.24-9

737 Ibid., pp.27-8
} 
and the languages spoken in Piedmont and Genoa with a series of songs in the dialect. ${ }^{738}$ Amongst these songs was a short round entitled 'O Gat e ro Giuge' - Le Chat et le Juge, in which a hunter catches a thrush, which is then stolen by a cat, who in turn is brought before a judge by the hunter. The judge takes the side of the cat, ruling that 'Soch o gat s'e piglià es tot sieu/ Tant l'invern coma l'estieu' (Ce que le chat a pris est le sien/ Autant l'hiver que l'été), an intervention Bruyn observed was made not in the same Mentonnais dialect of the rest of the song, but in 'Niçois. [since] le juge est rarement du pays'. ${ }^{739}$ This interjection seems to demonstrate that, at least within the popular singing culture of Menton, the judge might be expected to communicate in patois. He remained a linguistic outsider, but one hailing from the regional, rather than national capital.

Some caution is required before we might follow Bruyn in viewing this song as evidence of the kind of judicial bilingualism apparent elsewhere amongst the judiciary, or of popular expectation that judges would communicate in patois, albeit the patois of the local administrative capital rather than the town. Menton, as part of the county of Nice, had only been part of France for fifteen years when Bruyn Andrews published this song, following 45 years of Piedmontese rule, thus it is unclear whether this linguistic practice might have represented the norm under the French government. It might also be seen as somewhat convenient for such a song to manifest a linguistic distinction between Mentonnais locality and Niçard-speaking judge given Bruyn's assertion that Mentonnais should be considered a variety separate from Provençal. Yet Bruyn Andrews enjoyed a certain repute as a folklorist, publishing a number of collections of folktales from the region that turned precisely on their authenticity as collections of popular culture. A version of another of the songs accompanying this essay, Oh Isabelle, belle Isabelle, was collected by Achille Millien, one of the most prolific collectors of folklore in France during the nineteenth century, in the Nièvre. It can be found in the Repertoire des chansons françaises de tradition orale as song type 3409, indicating that at least some of the fragments and songs contained in this collection did have an existence within

\footnotetext{
$738 \mathrm{~J}$. Bruyn Andrews, Essai de grammaire du dialecte mentonnais, avec quelques contes, chansons et musique du pays (Nice, 1875)

739 Ibid., p. 74-5
} 
French oral tradition. ${ }^{740}$ Perhaps most significantly, the rhyming couplet 'sieu/estieu' would not have worked if Bruyn Andrews had simply replaced the Niçard 'estieu' (été) with the Mentonnais translation 'éstade', as listed in his dictionary of the dialect published two years later. ${ }^{741}$

These ambiguities were recognised by legal officials themselves. In the observations on the criminal code published by the tribunal of the Indre it states that 'dans certains tribunaux criminels, par exemple, dans celui séant à Limoges, le président, le commissaire du Gouvernement et les défenseurs des accusés sont obligés de porter la parole en patois, autrement ils ne seraient entendus ni compris par les jurés, les témoins et les accusés'. ${ }^{742}$ This was necessary because the juries, witnesses and the accused, 'assez ordinairement, appartiennent à la classe des habitans de la campagne' ${ }^{743}$ The members of the appeal court of Agen echoed the familiar refrain that the ambulatory magistrate would be unable to understand the local language. This was especially problematic, because 'c'est la classe du peuple qui ne parle que cet idiome, qui se trouve plus particulièrement en présence des tribunaux criminels, soit comme accusé, soit comme témoin'. ${ }^{74}$ Linguistic diversity was viewed by the members of the local judicial elites as the characteristic of a stigmatised social 'other'- as the 'habitans de la campagne', or as the tribunal of the Manche labelled those who spoke no French, 'la classe indigente et grossière'. ${ }^{745}$ Yet this stigmatization was accompanied by a valorization of linguistic and cultural diversity, an ambiguity reflecting the interstitial position of those who staffed the law courts in the interior, who formed a hinge between the centre and local society.

\footnotetext{
740 J. Bruyn Andrews, Contes Ligures : Traditions de la rivière recueillis entre Menton et Gênes (Paris, 1892) ; P. Coirault, G. Delaure, Y. Fédoroff and S. Wallon Répertoire des chansons françaises de tradition orale 1. La poésie et l'amour (Paris, 1996)

741 J.B. Calvino, Nouveau dictionnaire niçois-français (Nice, 1903) p.130 ; J. Bruyn Andrews, Vocabulaire français-mentonnais (Nice, 1877) p.65

742 'Observations du tribunal criminel de l'Indre', Observations des tribunaux criminel iii, p.15

743 Ibid., p.15

744 'Observations du tribunal d'appel d'Agen', Observations des tribunaux d'appel i, p.8

745 'Observations du tribunal criminel de la Manche', Observations des tribunaux criminel iv, p.25
} 
The dynamic was similar in the départements réunis, where many of the same ambiguities were also present. Judges were keen to cement their position within the Francophone legal system of the Napoleonic state. This was particularly striking in the case of the tribunal of the Lys, which was composed entirely of judges native to the department. After extolling the virtues of appointing judges to their home departments, the tribunal criticized the composition of jury lists, which they claimed 'présente toujours un amas d'individus de l'ignorance la plus crasse, dont la majeure partie ignore la langue française, et le reste ne sait ni lire ni écrire'. ${ }^{746}$ Although such views may have emerged from existing tensions between Walloons and Flemish speakers, criticism of non-Frenchspeaking jurists also emphasised the value of the bilingual judges of the Lys. Their position rested on their ability to mediate between Francophone centre and Flemish-speaking local society. The legal profession under Napoleon acted as a hinge between the Francophone structures of the French state and local society, leaving individual members of the legal elite to negotiate between these two poles of cultural identity. They were at once expected, as members of the legal bureaucracy, to move comfortably within French speaking circles, yet remain enmeshed in local structures. As an examination of the correspondence relating to legal appointments in Liguria and the Rhineland shows, French language became a marker of a new identity for some, but for many more this ambiguity was a source of tension and alienation.

\section{Language and Assimilation in the Legal Profession: The Examples of the Rhineland and Liguria}

The influence of the government's language policy had a clear impact on the composition of the judiciary in both the Rhineland and Liguria. From the correspondence on appointments, I have been able to identify the origins- that is to say either their place of birth or the jurisdiction within which they trained- of 79 judges in the jurisdiction of the court of appeal of Genoa, and 59 in that of Trier. ${ }^{747}$ The figures show that a substantially higher proportion of the judiciary in the Rhineland

\footnotetext{
746 'Observations du tribunal criminel de la Lys' Observations des tribunaux criminels iv, p.2

${ }^{747}$ See Tables 5 \& 6, Figures 14 \& 15
} 
were taken from the local population than in the jurisdiction of Genoa- $66.1 \%$ in the former as against $45.2 \%$ in the latter. This was not due to a heavier reliance on personnel from the interior. If judges from Alsace, Lorraine, and the rest of France are taken together, the Rhine had a larger proportion of judges from 'Old France' than Liguria. Rather, it resulted from the recruitment of officials from Piedmont- who comprised $26.6 \%$ of the total.

Table 5- Judges in the resort of the court of appeal of Genoa by origin

\begin{tabular}{|l|l|l|}
\hline Place of Origin & No. of Judges & $\%$ \\
\hline France & 17 & 21.5 \\
\hline Piedmont & 21 & 26.6 \\
\hline Genoa & 25 & 31.6 \\
\hline Parma and Piacenza & 11 & 13.6 \\
\hline Italy (other) & 5 & 6.3 \\
\hline Total & 79 & \\
\hline
\end{tabular}

Table 6- Judges in the jurisdiction of the court of appeal of Trier by origin

\begin{tabular}{|l|l|l|}
\hline Place of Origin & No. of Judges & $\%$ \\
\hline Rhineland & 39 & 66.1 \\
\hline Alsace & 6 & 10.2 \\
\hline Lorraine & 6 & 10.2 \\
\hline Rest of France & 8 & 13.6 \\
\hline Total & $\mathbf{5 9}$ & \\
\hline
\end{tabular}

The significance of this with regard to language becomes clear when one considers the conviction of French officials that Piedmont could provide a ready source of bilingual judges for other areas of Italy. It is also reflected in the origins of Francophone judges in Genoa- those judges that can be identified as having known French, either through correspondence with the minister of justice in the language or the comments of their superiors. ${ }^{748}$ Here the Piedmontese overtook the Genoese as the largest single group, representing $32.4 \%$ of the identifiable Francophone judges. A similar effect can be seen in relation to judges from Alsace and Lorraine in the Rhineland. Both these areas became pools for the recruitment of bilingual, apparently acculturated judges. This is striking

${ }^{748}$ See Table $7 \& 8$, Figure 16 \& 17 
since Piedmont was only annexed to France in 1802, and when an English traveller in Turin visited the appeal court in October 1802 he found the proceedings conducted in Italian. ${ }^{749}$ Clearly a significant number of Piedmontese legal officials adjusted to the linguistic demands of the French state by learning the language of Paris between the annexation of Piedmont in 1802, and 1805, when Genoa was incorporated into the Empire.

Table 7- Francophone judges in the jurisdiction of the appeal court of Genoa by origin

\begin{tabular}{|l|l|l|}
\hline Origin & No. of Judges & $\%$ \\
\hline France & 9 & 24.3 \\
\hline Piedmont & 12 & 32.4 \\
\hline Genoa & 3 & 27 \\
\hline Parma and Piacenza & 10 & 8.1 \\
\hline Italy (other) & 3 & 8.1 \\
\hline Total & 37 & \\
\hline
\end{tabular}

Table 8- Francophone judges in the jurisdiction of the appeal court of Trier by origin

\begin{tabular}{|l|l|l|}
\hline Origin & No. of Judges & $\%$ \\
\hline Rhineland & 13 & $52 \%$ \\
\hline Alsace & 5 & $20 \%$ \\
\hline Lorraine & 3 & $12 \%$ \\
\hline France (other) & 4 & $16 \%$ \\
\hline Total & $\mathbf{2 5}$ & \\
\hline
\end{tabular}

In the Rhineland, more Francophone judges came from Alsace and Lorraine than from the rest of France combined. The proportion of Francophone judges originally from the area was $52 \%$, almost $15 \%$ lower than the proportion of native judges in the area's judiciary as a whole, which was 62.2\%. The proportion of Francophone judges from France, including Alsace and Lorraine, was higher than the proportion of judges from France in the total population, demonstrating the importance of language in legal appointments. In order to reconcile the impulse to impose French with the need for officials who might understand those they were judging, the government turned to the bilingual legal elites of Piedmont and Alsace Lorraine. While the linguistic particularity of the

749 J.G. Lemaistre, Travels after the Peace of Amiens, Through Parts of France, Switzerland, Italy and Germany (London, 1806) pp.180-1 
population was accommodated within the informal bilingualism of legal practice during hearings, judges themselves were obliged to conform to the linguistic demands of the centre, as the adjustment of Piedmontese judges to French language proceedings shows. These legal officials secured their positions through the ability to function as cultural intermediaries between Paris and local society- for them, expertise both in the local language and in the authorized knowledge of the centralized bureaucracy was crucial.

These pressures allowed individuals who spoke French before the annexation to France to exploit their linguistic capacities. While Alsace and Lorraine were an important source of Francophone judges in the Rhineland, a significant proportion of Francophone judges were taken from local elites. As in Piedmont, proximity to France and the rayonnement of the French language resulted in a degree of spread of French within certain sections of the elite. Rhinelanders were considered 'frenchified' by other Germans during the period, and proximity to France also facilitated cross border migration. ${ }^{750}$ Historically, Protestants had moved from France into the Rhineland, although it was not unheard of for individuals to travel in the opposite direction. For example, in 1802 the President of the criminal court at Speyer was Charles Joseph Boost, a bilingual native of Mainz. Having studied at the universities of Mainz and Strasbourg, Boost fulfilled a number of roles for the electorate of Mainz before the entry of General Custine in 1792, at which point he accepted a position under the French. ${ }^{751}$ The biography of J.J. Haan reveals a similar trajectory. Haan was born in 1754 'sur les frontiers de l'ancien territoire de la France, [and] élevé en partie en cet Empire, en partie en Allemagne'. ${ }^{752}$ Haan studied in Nancy, Trier, Mainz and Rheims, before being admitted to the parlement of Metz as a lawyer, a position he left for a role overseeing education, and then military justice in one of the electorates of the Holy Roman Empire. ${ }^{753}$

\footnotetext{
${ }^{750}$ Aaslestad, Place and Politics p.14

${ }^{751}$ An BB5 258 (Organisation judiciaire- Mont-Tonnerre) Boost au Ministre de la Justice, 24 vendemiare an XI (16 ${ }^{\text {th }}$ October 1802)

752 An BB 5256 (Trèves) Haan au Ministre de la Justice, 5 May 1811

${ }^{753}$ An BB 5256 (Trèves) Haan au Ministre de la Justice, 5 May 1811
} 
The linguistic demands of the state allowed individuals such as Haan and Boost to exploit their bilingualism, and encouraged others to cultivate knowledge of French. Such pressures were manifested in the disparaging attitude of the French towards the linguistic capabilities of local officials. In 1811, a leading candidate for the place of procurator at the Imperial court of Trier was described in glowing terms, save for his French; 'Il n'a pas le talent de parler la langue française $d^{\prime}$ une manière très facile $\&$ très correcte, étant originaire allemand ${ }^{\prime}{ }^{754} A$ candidate for judge in the court at Zweibrüken was felt to be 'généralement estime par sa probité \& par sa moralité, mais il s'explique difficilement en français' ${ }^{\prime 75}$ Yet these criticisms also reveal something of the impact of policies in favour of French, for such men must have been obliged to toil in the language so that such opinions could be formed and deemed relevant. Above all, the French could view language as a proxy for political loyalty, or lack thereof. A certain M. Ferber, proposed for the place of greffier du juge de paix of Germünd in the Roer, was apparently 'connu pour un homme capricieux, français malgré lui et ne connaissant pas suffisamment la langue française'. ${ }^{756}$ The report on the candidate thus conflated his trustworthiness with his lack of linguistic ability, and above all, the damning conclusion that he would rather not be French at all.

Some individuals embraced French without reserve. Such was the case with Domenico Alberte Azuni, the author of the section on maritime law of the Napoleonic code. Azuni was born on Sardinia, taking up a role in the judiciary in the county of Nice before the Revolution. In the 1790s he published a series of legal essays in Italian, but in $\mathbf{1 7 9 8}$ he chose to write his history of Sardinia in French, with translations of his previous work in this language following. ${ }^{757}$ In May 1812 a petition was received by the Minister of Justice in which the author claimed that he beleived it necessary 'd'appeler sur lui votre attention particulière, dans un moment où la jalousie italienne s'agite pour l'écarter, sous le misérable prétexte qu'il n'est pas né génois' M. Azuni est bien plus que Génois, car

\footnotetext{
${ }^{754}$ An BB5 256 (Trèves) Garreau, président de la cour d'appel de Trèves au Ministre de la justice, 27 feb. 1811

755 An BB5 256 (Trèves) Liste des candidats pour le tribunal de premier instance de Deux Ponts 18th August 1810

${ }^{756}$ An BB8 48 Liste des candidats pour la place de greffier du canton de Gemund, Röer

${ }^{757}$ An BB5 296 (Organisation judiciaire- Gênes) État des services de M. Dominique Azuni
} 
il est bon françois'. ${ }^{758}$ The dynamic of tension in the courts existed as much between Piedmontese 'outsiders' and Genoese 'natives' as between Italians and French. Moreover, Azuni had invested in the French state, even the notion of being French, and the necessary corollary to this position was the use of the French language.

Azuni was probably not typical of the reaction of local officials to the state's pro-French language policy. The language, the policy and the means the French used to pursue them were all rejected or contested in various ways, even by those who chose to serve the regime. This contestation frequently took the form of an explicit rejection of the outsiders drafted in by the French at least in part thanks to their linguistic capacity. In the courts of Genoa this pitted Genoese against Piedmontese, the former resentful of the favour shown to the latter by the French. In the Rhineland it was the French who were considered rivals, with language frequently an issue. In the summer of 1799 a series of complaints were made against three French judges sitting on the civil court of the Rhin-et-Moselle. According to the German judges who expressed their discontent to the Minister of Justice, these three judges spoke no German, which meant a disproportionate quantity of work fell on their German colleagues. ${ }^{759}$ These tensions lasted throughout French rule. In 1811, Dupont, the French Vice-President of the tribunal at Koblenz described a somewhat different experience: 'Je me suis trouvé en arrivant à Coblentz avec 19 juges allemands qui n'avoient que quelques notions de la langue française [...] c'est alors qu'il a fallu me sacrifier, guider les juges, instruire les avocats'. ${ }^{760}$ Dupont went on to note with dismay that his 'former disciples' were agitating to replace him, arguing that while they might need a Frenchman in the presidency, they would be better with a German in the vice-presidency. ${ }^{761}$ This in a sense represented a significant boundary, even for those who chose to serve the Napoleonic state. The use of French as the language of legal practice, like French rule itself, remained something foreign, imposed from outside.

\footnotetext{
758 An BB5 296 (Gênes) Fabre au Ministre de la Justice, May 1812

${ }^{759}$ An BB5 255 (Rive Gauche du Rhin) Membres du tribunal civil du department du Rhin \& Moselle au Ministre de la Justice, 25 Messidor an VII (13 ${ }^{\text {th }}$ July 1799)

760 An BB5 256 (Trèves) Dupont au Ministre de la Justice 10th October 1810

${ }^{761}$ An BB5 256 (Trèves) Dupont au Ministre de la Justice 10th October 1810
} 
The often superficial impact of French cultural imperialism even amongst the elites who staffed the institutions of the French state was apparent in a dispute arising over the falsification of a certificate by Alexandre Buratti, a lawyer and substitute in the cour de première instance of San Remo. According to the minutes of the incident drafted by the procureur of the court, Buratti admitted his forgery, but sought to gain the approval of the other members of the court for his action by invoking a shared disdain for the central authority, saying '" mais que quant à cette dernière ce n'étoit pas du Gibier pour le ministère public » et il a prononcé ces dernière mots en fixant ses regards sur nous avec humeur' ${ }^{762}$ When the other members of the court reproached him for such a mutinous statement, Buratti 'a cherché faiblement alors tout en convenant à plusieurs reprises de s'être servi de cette locution insultante, à s'en excuser en allégeant qu'il connoit mal la langue français; et il nous a mis, par là dans le cas de lui répondre qu'il sait le français quand bon lui semble'. ${ }^{763}$ Buratti manifested distaste for the central authority of the French state and crucially, when confronted with his corruption and impolitic choice of words, he pursued a strategy of renouncing his competence in French, unsuccessfully seeking refuge in the notion that as an Italian his grasp of French was tenuous, making the misunderstanding possible. He displayed no compunction about forfeiting his status as a French speaker, which had only served the transitory purpose of attaining employment within the bureaucracy.

The legal system was central to the regime's attempt to integrate the territories and populations of the Empire. The government considered it a tool with which it sought to unify and regularize the societies over which it ruled. This process of centralization involved an effort to create a Francophone legal system across the Empire. However, the features of this system enabled local legal elites to mediate the linguistic demands of state and local community. This placed members of the judiciary under the greatest linguistic pressure. It was they who would translate between the written French and the oral sphere of legal debate, and thus they who were forced to acculturate to

${ }^{762}$ An BB 5322 (Organisation judicaire- Alpes-Maritimes)
${ }^{763}$ An BB 5322 (Organisation judicaire- Alpes-Maritimes) 
French rule by learning the language of the newly dominant state. Yet the apparent cultural dominance of French amongst this group was a chimera. As a professional grouping, a large swathe of the judiciary owed their positions to their knowledge of French, yet in none of the linguistically complicated communities of the empire did this result in the straightforward establishment of French as an uncomplicated marker of status and prestige. Some men, such as Azuni, did accept the prestige of French as a given. Above all, the members of the legal profession were engaged in a process of negotiation over cultural and linguistic identity between Paris and province, a process analogous to that observed in the writings of the local officials who studied language for the Coqueberts and the teachers who sought to bring French to the Alpes-Maritimes. Their positions rested on their ability to mediate between state and local society and the strategies they pursued reflected their need to establish their expertise both in the authorised knowledge of the centre and the particular knowledge of the local. 


\section{Organised Religion, Language and the French State from Ancien Régime to Napoleon}

On the afternoon of the $21^{\text {st }}$ February 1803 , the faithful of the parish of the Major in the town of Arles assembled in celebration of the forty hours devotion. Nalis, the parish priest, had settled on the rite of penitence as the topic for his sermon. This may have seemed a less astute choice of subject when, mid-way through his instruction, an apprentice tanner named Louis Aillaud rose to harangue the unfortunate clergyman, shouting 'va te faire $f . .$. nous ne voulons point de ta pénitence, et nous n'en faisons point' ${ }^{764}$ Aillaud continued his invective as several members of the congregation ushered him forcefully from the church. The visibly shaken curé halted his sermon and descended the pulpit. The commissaire du police despatched the following day to investigate the incident noted pointedly in his report that Aillaud had made his intervention 'à haute voix en idîome du paÿs'; that is, in the dialect of Provençal spoken in Arles. ${ }^{765}$

While anecdotal, Aillaud's raucous Provençale interjection nonetheless reveals a crucial facet of the relationship between the nineteenth century Catholic Church and France's regional languages. For historians in hock to narratives of modernisation and secularisation, the use of a language other than French and a continued adherence to the Catholic faith have frequently been conflated as manifestations of a deeper structure, that is of an enduring traditional, rural society at odds with the secular French-speaking culture of Paris facing elites. ${ }^{766}$ Religious observation, like the patois themselves, would simply fall away once the economic and political integration of the population of France made them obsolete. ${ }^{767}$ The impression that Catholicism and regional languages were both characteristically traditional was underscored by the contributions of a vocal section of the French clergy who, at the end of the nineteenth century, increasingly viewed local patois as a bulwark against the corrupting influence of Francophone modernity. In the 1890s for

\footnotetext{
${ }^{764}$ An F19 5660 (Police du culte- Bouches du Rhône) Pomme au Ministre des Cultes, 4 Ventose an XI (23 Feb. 1803)

765 An F19 5660 Procès-verbal dressé par Jean-Baptiste Jéhan, commissaire du police d’Arles

${ }^{766}$ Furet and Ozouf, Reading and Writing p.298

${ }^{767}$ Weber, Peasants p.345 ; Much recent historical work has cast doubt on the narrative of secularization, see C. Ford 'Religion and Popular Culture in Modern Europe' in The Journal of Modern History Vol.65 no.1 (1993) pp.153-4
} 
example, figures such as Justin Bessou, the félibre and priest from the Aveyron insisted that 'foi, patois et paysan sont trois qui ne font qu'un'. ${ }^{768}$ In the following decade, scores of Breton, Basque and Flemish clergymen staunchly resisted Emile Combes' interdiction of languages other than French in Catholic preaching and teaching. ${ }^{769}$ These men forfeited their government stipends, but in the process they provided a tangible manifestation of a Catholic faith tied to tradition, financial martyrs to linguistic activists and Catholic reactionaries. Yet, a century earlier, here was a Provençal speaker lashing his pastor over a fundamental tenet of Catholic doctrine, the sacrament of penance imposed by the priest during confession. Aillaud's harassment of his curé reminds us that the clergy were an elite whose interest in regional languages was grounded in an attempt to regulate the beliefs and cultural practices of those who experienced the most meaningful parts of life in a tongue other than French, and this attempt to control and regulate was not always successful. ${ }^{770}$ Preaching in patois was, as one commentator has phrased it, primarily an attempt to diffuse 'elite' religious culture and practice into a 'popular' milieu more effectively. ${ }^{771}$

The noise created by those Catholic conservatives vehemently opposed to the intrusion of the Third Republic into spheres such as primary education which they regarded as properly the purview of the church should not obscure the commitment of the church to the reform of popular culture, and the more ambiguous attitudes towards regional languages that this implied. Even in fin de siècle Brittany, an ambivalence towards Breton was evident amongst the episcopate and clerical hierarchy. The Bishop of Quimper recognised that his priests remained obliged to use Breton in the course of their pastoral functions, whilst simultaneously expressing a hope that in the future such provisions might no longer be necessary. ${ }^{772}$ Meanwhile, the more vociferous defenders of the Breton language amongst the clergy, such as the Académie Bretonne, active in the seminary at

\footnotetext{
768 Cited in G. Cholvy, Christianisme et société en France au XIXe siècle 1790-1814 (Paris, 2001) p.87

${ }^{769} \mathrm{~F}$. Broudic, L'interdiction du breton en 1902: La Ille république contre les langues régionales (Spézet, 1996) p.174

770 G. Cholvy 'Le Catholicisme populaire en France au XIXe siècle' in B. Plongeron et R. Plannet (eds.) Le christianisme populaire (Paris, 1976) p.199

${ }^{771}$ M.-H. Froeschlé-Chopard, La Religion populaire en Provence orientale au XVIIle siècle (Paris, 1980) p.271

772 M. Lagrée, Religions et cultures en Bretagne, 1850-1950 (Paris, 1992) pp.221-4
} 
Quimper in the 1890s and 1900s, were not entirely representative of broader clerical opinion within the diocese. While these members of the Académie saw Breton as both a bulwark against Francophone secularisation and a uniquely powerful means of reaching parishioners, other clergymen used the local language out of pragmatism, because otherwise they would not be understood. ${ }^{773}$ The clergy of the 1890s prove an effective guide to the clerical and episcopal attitudes towards language expressed during the Revolutionary and Napoleonic period only insofar as they were characterised by a lack of consensus. While views on language cannot be deduced from the political choices of the clergy during the Revolution, it seems that a large number of clergy, perhaps even a slight majority of parish priests, were willing to support the early religious reforms of the 1790s, even if they were opposed by most of the episcopacy. ${ }^{774}$ Many of these curés and vicaires were themselves persuaded of the need for reform. Men like the Abbé Grégoire, future constitutional bishop and linguistic nationalist in chief, were influenced by the enlightenment model of the bon curé, committed to the interests of his flock, by Jansenism and above all Richerism, a doctrine that asserted the central role of the curé and his pastoral functions to the church. ${ }^{775}$ They did not necessarily perceive a contradiction between the spread of French and a revitalised Catholic faith.

Aillaud's intervention shows that we need to understand the place of language in religious practice not only in terms of Church-state relations and the struggles over secularisation and modernisation, but with reference to the strategies of clergymen and faithful as they sought to position themselves socially. While accounts of the incident provide no indication of the language used for the sermon by Nalis, the inclusion of the language in which Aillaud made his intervention as part of the police report appears only to underline his culpability. Hectoring the priest in French

\footnotetext{
${ }^{773}$ C. Brunel, 'L'académie bretonne au grand séminaire de Quimper' in M. Lagrée (ed.) Les parlers de la foi: Religion et langues régionales (rennes, 1995) p.43

774 T. Tackett, Revolution and Regional Culture in France: The Ecclesiastical Oath of 1791 (Princeton, 1986) p.45

${ }^{775}$ On the idea of the bon curé; J. McManners Church and Society in Eighteenth Century France, vol. 1: The Clerical Establishment and its Social Ramifications (Oxford, 1999) pp.358-360; On the Abbé Grégoire and Richerism see Sepinwall, Modern Universalism p.47
} 
might have been considered less problematic for the same reason many of the clergy in Brittany preached in Breton- because the faithful were not expected to understand the national language. Tensions over the language of religious practice arose precisely because of the nature of the priest as a local elite whose role was to guide and regulate the community. Members of the clergy engaged in pastoral work were concerned to preserve their status as members of an educated elite, and cognisant that speaking French was one sign of members in such a club. This was, therefore, one added factor which, as will be seen, perhaps explains the contrast between a 'French' episcopate eager to second the efforts of the Napoleonic state in the creation of a unified Catholic liturgy, and those areas of the départements réunis where this proved a more divisive effort. Above all, as will be seen, the relationship between religion and language cannot be reduced to a simple opposition between the French-speaking secular state and the patois-speaking church.

\section{Two Frances: Confessional and Linguistic?}

After these preliminary observations it seems a propos to wonder how far the 'traditional' alignment between Catholic practice and regional languages, imagined by clergymen in the course of the 1890s and reproduced by historians since, in fact reflected the reality of the early nineteenth century. The curé Nalis and his run in with Louis Aillaud once again proves instructive in this regard. During the Revolution, Arles was notoriously a 'bastion of Catholic royalism'. ${ }^{776}$ A constant, perhaps even belligerent, adherence to traditional Catholic piety into the Napoleonic period was evident in the fracas of February 1803, and not simply in Nalis' choice of penitence as the subject of his sermon. The $21^{\text {st }}$ February of that year was a Monday, significant because the articles organiques of 1802, which regulated the practice of both Catholic and Protestant faiths, limited the celebration of religious festivals to Sundays. In presenting the articles organiques to the Tribunat, Jêrome-Joseph Siméon observed 'on rapprochait au culte romain la multiplicité de ses fêtes: plus de fêtes sans la permission du Gouvernement, à l'exception du dimanche, qui est la fête universelle de tous les

${ }^{776}$ N. Aston, Religion and Revolution in France, 1790- 1804 (Basingstoke, 2000) p.173 
chrétiens'. ${ }^{777}$ In truth, much criticism of the excessive number of Catholic festivals before the Revolution had come from within the Church itself. By the end of the Ancien régime the number of days given over to religious festivities had reached 50 per year in some parts of France, and members of the clergy, both curés and bishops, frequently inveighed against the immoral conduct of their flocks on such occasions. ${ }^{778}$ While the state may have been more interested in freeing up days for productive labour, in acting to reduce the number of religious festivals, and transferring their celebration to Sundays, the provisions of the Organic Articles reflected the episcopal efforts of the previous century. In continuing the celebration of the festival of forty hours into Monday and Tuesday, Nalis exposed himself to criticism from the mayor, but also underscored a continued commitment to practise a traditional orthodox version of the Catholic faith in the parish. ${ }^{779}$

However, the reputation of Arles as a stronghold for royalism and traditional Catholic fervour rested precisely on a comparison with the rest of lower Provence. Historians have generally employed two measures of religiosity to give an impression of the religious geography of France: the proportion of priests taking the ecclesiastical oath imposed by the Revolutionary state under the Civil Constitution of the Clergy in 1791; and the numbers of Easter communicants in the various dioceses of France. It has been argued, based on this data combined with comparative information on literacy rates from across the country, that 'two Frances' can be observed, one Francophone, literate and secular, the other patois-speaking, largely oral and deeply religious, separated by the famous 'St Malo- Geneva' line described by Louis Maggiolo running from north-west to southeast. ${ }^{780}$ If one assumes a low rate of oath taking amongst the clergy to reflect a high level of commitment to the Catholic Church there does appear to be some correlation between a commitment to ultramontaine Catholic piety and linguistic difference. The Parisian basin and

\footnotetext{
${ }^{777}$ Rétablissement de la religion en France, ou Recueil de pièces authentiques et intéressantes, sur l'organisation des différens Cultes (Leide, 1802) pp.94-5

778 B. Plongeron, 'Le procès de la fête à la fin de l'Ancien Régime' in B. Plongeron et R. Plannet (eds.) Le christianisme populaire (Paris, 1976) pp.172-3

${ }^{779}$ An F19 5660 Préfet du Bouches du Rhône au Ministre des Cultes, 9 ventôse an XI (28 Feb. 1803)

${ }^{780}$ Furet and Ozouf, Reading p.25 ; See above, ch. 2
} 
surrounding departments appear as the heartland of clerical commitment to the religious reforms of the Revolution, while non-French speaking areas such as Brittany in the west, Alsace-Lorraine in the east and large parts of the Occitan-speaking south generally saw few priests take the oath. ${ }^{781}$ This trend, however, does not resist close scrutiny. Despite the presence of Catholic Arles, eighty percent of priests in the Bouches-du-Rhone took the oath. ${ }^{782}$ The number of clergy in Provence and Dauphiné taking the oath approached the highs of the Parisian basin, far higher than in Languedoc to the east, yet regional languages were spoken in both areas. Similarly in Alsace, while numbers taking the oath were fairly low, they were significantly worse in the Bas Rhin than in the Haut Rhin, yet both départements had a majority of German speakers. Of course, the swearing of oaths to the Civil Constitution provides only a synchronic view of the issue in 1791. Church state relations could deteriorate quickly, as in the Hérault where there was a spate of clergy retracting their oaths in $1792 .{ }^{783}$ Yet the diversity of reactions to state religious policy militates against the straightforward association of religiosity with linguistic diversity.

Other indicators also point to an equally variegated picture. As Gérard Cholvy has observed, the picture emerging from rates of Easter communicants was every bit as complicated as that revealed by a willingness to take the oath. ${ }^{784}$ In putting this information together with other information such as the rate of recruitment into the Catholic Church, Cholvy and Hilaire present a geography of religious devotion that coheres awkwardly with the linguistic divisions of the French population. ${ }^{785}$ Again the Parisian basin remains thoroughly uncommitted to the practice of the Catholic religion throughout the nineteenth century, while areas like Brittany and Alsace display a high degree of religiosity. Yet this piety was not confined to linguistically diverse areas. In the west, religious devotion was high in French-speaking areas like Normandy and the pays de Loire, where

\footnotetext{
781 Tackett, Revolution and Regional Culture pp.52-6

${ }^{782}$ Aston, Religion and Revolution p.173

783 H.C. Johnson, The Midi in Revolution. A Study of Regional Political Diversity, 1789-1793 (Princeton, 1986) p.138

${ }^{784}$ Cholvy, Christianisme et société p. 88.

785 G. Cholvy and Y.M. Hilaire, Histoire religieuse de la France, vol 3 : Géographie XIXe-XXe siècle (Toulouse, 2000) pp. 45-109. A summary map of the situation around 1880 can be found on p.46
} 
departments such as the Manche, Mayenne and large parts of Calvados saw Easter communicant rates of $75 \%$ and higher in rural areas during the nineteenth century. The Catholic Church was strong in the Touraine, proverbially home to the 'purest' of spoken French, which enjoyed a fairly respectable $53 \%$ between 1858 and $1862 .{ }^{786}$ The area also saw its share of religious dissidence during the Napoleonic period, with priests in the town of Vendôme arrested for expressing their discontent with the concordat, although this was insignificant compared to events in traditional centres of clerical resistance to state power such as the Vendée and parts of the Midi. ${ }^{787}$ It is equally possible to distinguish areas characterised by a high degree of de-christianisation in the Occitanspeaking south. Cholvy and Hilaire distinguish a band of strong religious practice running from the Franche-Comté in the east, through parts the Auvergne and Languedoc to Béarn and the Basque country in the west. ${ }^{788}$ Yet equally, the coastal littoral of the Mediterranean was markedly less fervent in its Catholicism. In Montpellier in 1866, only 15\% of men completed their Easter devotions. ${ }^{789}$ In short, the linguistic and confessional geographies of nineteenth century France aligned only imperfectly.

\section{The Catholic Church and the 'Langue Vulgaire'}

The role given over to regional languages in religious worship during the period provides no more clarity on the relationship between Catholic devotion and linguistic alterity. While Latin continued to dominate Catholic liturgy, vernacular languages necessarily played an important role in the organized worship of the church. The use of a vernacular language was crucial in the practice of the faith, for assailing the congregation in what was essentially a dead and unfamiliar tongue could scarcely cater for the spiritual needs of the faithful. The official formulae for confession, baptism and marriage were all given over to the vernacular, which also replaced Latin in the parish curé's 'prône' or sermon, in the preaching of religious missionaries, and of course in the catechism, although it was

\footnotetext{
${ }^{786}$ Cholvy and Hilaire, Histoire religieuse vol. 3 p.45

787 M. Broers Napoleon : Soldier of Destiny (London, 2014) pp.340-1

${ }^{788}$ Cholvy and Hilaire, Histoire religieuse vol. 3 p.69

789 lbid., p.94
} 
not always clear which language functioned as the 'vernacular'. ${ }^{790}$ In 1790, the Abbé Grégoire included the question, 'prêchait-on jadis en patois? Cet usage, a-t-il cessé?' as part of his survey on the patois, circulated to the Société des amis de la constitution. ${ }^{791}$ The responses generated by Grégoire's questionnaire reveal just how widely the place afforded to regional languages within religious practice of the Catholic Church varied.

In some parts of France, it seems that French played only a minor role. In Brittany, for example, Breton, rather than French, seems to have been the preferred language of the clergy when addressing the faithful. Pierre Riou, a wealthy farmer or 'Laboureur' from Plougonil in the department of Finistère wrote to Grégoire that 'de tout temps l'on prêche dans les campagnes en breton, les villes mêmes partagent leurs conférences dans les deux idiomes, la commodité [de] I'ensemble'. ${ }^{792}$ Similarly, in the department of the Landes, formerly part of Acquitane, the Société des amis de la constitution of Mont de Marsan informed Grégoire that 'l'on prêchait jadis et l'on prêche encore qu'en gascon dans nos campagnes. Cet usage existe même dans quelques villes'. ${ }^{793}$ In other areas it was French rather than the local dialect that dominated the church's pastoral activities. This was the case in the Franche-Comté, where one respondent from Saint-Claude in the department of the Jura claimed that the local patois had never been used for preaching, and another informant from the same department elaborated that he had only ever known one curé, now deceased, who had preached in patois. ${ }^{794}$ Similarly, the respondent from the town of Maringes, in the Auvergnat department of the Puy du Dome, claimed that 'on ne croit pas que jamais il y ait été prêché en patois, ou cet usage est perdu dans la mémoire des habitants' ${ }^{795}$ In the Mâcconais region of Burgundy, all religious instruction was performed by the clergy in French, despite the fact that,

\footnotetext{
${ }^{790}$ R. Bertrand 'Usages religieux du provençal aux XVIIle et XIXe siècles' in M. Lagrée (ed.) Les parlers de la foi : Réligion et langues régionales (Rennes, 1995) p.111

${ }^{791}$ Gazier, Lettres p.9

792 lbid., p.282

${ }^{793}$ Ibid., p.150

794 Ibid., pp.203, 209

795 Ibid., p.164
} 
according to one of Grégoire's correspondants, 'il n 'y a pas de doute qu'elles fussent, sinon plus fructueuses, du moins plus à leur portée, si elles se faisaient en patois' ${ }^{796}$

In general however, religious practice was not dominated by one or the other vernacular languages. The social and linguistic divisions of a bilingual society were reflected in the languages employed for religious worship. Most commonly, an apparent town-country divide was reinforced by the language used in church. The political club of Carcassonne in the Languedoc wrote to Grégoire that 'on prêche en français dans la ville, dans les villages voisines et dans les bourgs; mais I'usage de prêcher en patois est usité et pratiqué presque partout ailleurs'. ${ }^{797}$ The distinction between town, where French might well dominate the language of religious practice, and village, where it was more likely to be patois, was a palpable manifestation of the divergent status and prestige of the national language and the local dialect, as was evident in the response received by Grégoire from the Limousin department of the Haute-Vienne. The Sociéte des amis de la constitution of the town of Limoges observed that less than a century beforehand, even the public prayers and sermons of the church of Saint Peter, the town's first parish, were conducted in Limousin. This innovation inscribed the socio-linguistic stratification of the urban population onto religious practice within the town, for according to the information supplied by the Société of Limoges, 'il n'y a pas dix ans que le prône se faisait en patois aux premières messes des trois principales paroisses, auxquelles assistaient les domestiques et les artisans' ${ }^{798}$ The great and the good, the socially aspirant and wealthy, would thus attend a service with sermon and prayer in the prestigious language of the royal court, while servants and artisans would worship in patois. While French apparently now dominated religious worship within the town, social differentiation still influenced the language used in church,

\footnotetext{
796 Gazier, Lettres p.222

797 Ibid., p.19

798 Ibid., p.171
} 
since 'les prédications se font encore actuellement en patois par les curés de campagne, et que les missionnaires n'y parlent pas d'autre langue'. ${ }^{799}$

The linguistic disjunction in confessional practice did not stop at the parish boundary, and it was common for different parts of the religious life of a single community to take place in different languages. François Chabot, the former Capuchin friar who went on to marry following the Civil Constitution of the Clergy, in addition to serving as Grégoire's vicaire général in the Bishopric of Blois, wrote from the department of the Aveyron in the former Languedoc, that 'Les prônes se font partout en patois, excepté à Rodez, à Villefranche et à Milhau, ainsi que les catéchismes', thus reiterating the distinction between rural and urban religious practice ${ }^{800}$ However, he also reported that all the 'sermons de parade', the exterior celebrations of Catholicism, took place in French, even though most of those who understood the language rarely attended, at least according to Chabot. ${ }^{801}$ Pierre Bernadau, formerly a lawyer in the parlement of Bordeaux, informed Grégoire that 'on ne se rappelle pas avoir jamais entendu prêcher en patois dans ce district, mais les instructions du catéchisme s'y font dans cet idiome' ${ }^{802}$

The distinction between the French preaching of the curé, and the congregation that prayed in patois was reflected in the publication of religious texts throughout the period. Collections of sermons and preaching guides invariably appeared in French, while those works intended for the consumption of the faithful- the collections of canticles, carols and prayers intended to guide the flock's contribution to the worship of the divine - were all frequently printed in regional languages. From the basis of this divergence in the kinds of religious texts printed in one or the other language, one commentator has drawn a distinction between the 'descendant' speech of the curé to his flock, generally appearing in French on the printed page, and the 'ascendant' speech of the faithful towards God, published in regional languages so that the non-Francophone worshipper might

\footnotetext{
799 Gazier, Lettres p.171

800 lbid., p.58

801 lbid., p.58

802 Ibid., pp.127, 139
} 
understand the significance of the words they were uttering. ${ }^{803}$ The transition between languages might even take place within the pages of a single publication. In 1724 a collection of prayers and religious song for the use of the Jesuit missionaries in Marseille was produced by the official printers of the bishopric. ${ }^{804}$ The volume contained morning and evening prayers in French, followed by a series of prayers set to music and canticles predominantly, though not exclusively in Provençal. The daily prayers offered by the Jesuits as a sign of their devotion, then, were printed in French, while the religious songs, the tools with which they sought to excite fervour amongst a non-Frenchspeaking public, appeared in Provençal.

The preference of the Catholic clergy for forming the written word in French rather than the less prestigious regional languages did not originate in the printing presses with typesetters habituated to the language of the capital. Manuscript versions of the religious texts used in Catholic devotion were invariably made in the language of Paris rather than the province. A collection of sermons from the parish of Saint-Pierre in Avignon, for example, was drafted entirely in French, save for a litany dedicated to the patron Saint Peter of Luxembourg, which was written in Latin and accompanied by a song in Provençal exhorting the congregation to 'canten [sic.] ben touttei [sic.] a I'honnour de San Pierre de Luxembourg' ${ }^{805}$ The parish archives of the village of Maubec in the Vaucluse contain a volume of eighteenth century sermons written in French, with Latin passages translated into the language of Paris, but no trace of Provençal to be found ${ }^{806}$ Of course, the language in which a sermon or other element of religious service was written need not have determined the language in which it was used. Indeed, it was rare for catechisms in the eighteenth century to be produced in a language other than French, yet one presumes that Pierre Bernadau's

\footnotetext{
${ }^{803}$ R. Merle, 'Du catéchisme en provençal, 1825-51', M. Lagrée (ed.) Les parlers de la foi, religion et langues régionales (Rennes, 1995) p. 136

${ }^{804}$ Prières du matin et du soir et quelques cantiques provençaux et françois à l'usage des Missions des RR. Peres Jésuites à Marseille (Marseille, 1724)

805 AdV 37 J 37 (Fonds de la paroisse Saint-Pierre d'Avignon)

${ }^{806}$ AdV $31 \mathrm{~J} 10$ (Fonds de la paroisse de Maubec) Sermons du curé, XVIIle siècle. The imperative form of the verb 'cantar' ('to sing') is generally written 'canten' rather than 'cantem', while Frédéric Mistral noted 'tóutei' as a Marseillais variation of 'touti', 'tout' (all). F. Mistral, Lou trésor dou félibrige ou dictionnaire proveçalfrançais (Arles, 1979) ii, p.1017
} 
observation that the catechism took place in patois must have held for many areas of France where clergymen were keen to imbue the tenets of Catholicism in a non-Francophone population. ${ }^{807}$ As with the religious practice of the Catholic Church, within the written culture, both manuscript and printed, of the clergy, French and patois tended to be apportioned distinct roles. In this way, the linguistic stratification of French society imprinted itself on the hierarchy and practices of French Catholicism. As the correspondence gathered by the Coqueberts between 1806 and 1812 shows, the lack of conventions regarding orthography and grammar often meant the local notability did not feel comfortable writing in dialect. ${ }^{808}$

To judge from their writings as well as from accounts of their religious practice, a preference for French in contexts ranging from pulpit to page was common within the ranks of the clergy during the late eighteenth century. Between the prestige of French as the language of educated written culture, and strains of enlightened Catholicism which saw the improvement of society as part of the church's mission, the place of regional languages in religious practice came under question. The episcopate was central in determining linguistic policy within the church, and some bishops disposed to reform the practices of the church in their dioceses sought to banish regional languages from the religious practice of their clergy. According to a response sent to Grégoire from the south-eastern department of the Gers, Claude-Antoine de Apchon Bishop of Auch from 1776 until 1783, and his successor, Louis-Apollinaire de la Tour de Pin-Montauban, had both attempted to replace Gascon with French in the religious practice of the diocese. Their efforts, however, had floundered on the opposition of the parish curés, for whom 'I'instruction en patois les dispensait de tout travail'. ${ }^{809}$ Some curés did understand their role to include enlightening their flock by introducing literacy and the French language. Jean-Baptiste Deguigues, for example, sought to bring metropolitan culture to

\footnotetext{
${ }^{807}$ Merle, 'Du catéchisme en provençal' in Lagrée (ed.) parlers de la foi pp. 135-6

${ }^{808}$ See above, ch. 3

${ }^{809}$ Gazier, Lettres p.95
} 
his parishoners in a small village near Vence during the early years of the nineteenth century.

Deguigues leant books and gave readings at the veillée, a traditional winter evening gathering. ${ }^{810}$

Deguigues' efforts to educate his parishioners were ultimately unsuccessful- he was accused of witchcraft and debauchery and denounced by his bishop as a Jansenist- and such projects were not the rule amongst parish clergy. The curés of the diocese of Auch were not alone in viewing the use of regional languages as an unavoidable necessity for the fulfilment of their pastoral functions. However, this was likely a reflection of the realities of administering a parish, rather than a rejection of Francophone metropolitan culture. In March 1719, the Bishop of Vence asked his clergy to consider this necessity as part of their monthly cantonal conferences, the regular meetings of parish clergy instituted across France as part of the Catholic reformation drive to engage previously isolated village priests with the church's mission. ${ }^{811}$ The curés attending this particular conference were asked to consider whether 'les curés sont obligés de comprendre la langue de leurs paroissiens [ou] s'il suffit qu'ils aient un secondaire qui la sache parler'. ${ }^{812}$ Of the fifteen local curés present only one, Eusiéros of the parish of Saint-Paul, claimed that a curé could continue to serve his parishioners without speaking the local language. Eusiéros reasoned that the curé could still instruct those who understood French, 'ce qui n'est pas si rare', while working through a secondary who did speak the language would enable him to minister the rest of his flock. ${ }^{813}$ Most of the other responses simply observed that it would be impossible for a curé to carry out his functions without speaking and understanding the language of his parishioners. One curé worried that a priest who not could explain the tenets of the Catholic faith to his parishioners in a language they could understand 'seroit un idol non pas un pasteur', a curious statement since one presumes he would not have considered the

\footnotetext{
${ }^{810}$ M.H. Froeschlé-Chopard, 'Entre peuple et hiérarchie: l'échec d'un pastorale', in Dix-huitième siècle no.12 (1980) pp.271-92 ; on the veillée see M. Lyons Reading Culture and Writing Practice in Nineteenth Century France (London, 2008) ch.7

${ }^{811} \mathrm{~T}$. Tackett, Priest and Parish in Eighteenth Century France (Princeton, 1977) pp.83-4

${ }^{812}$ AdAM G 1306 (Fonds de l'Evêché de Vence) Conférences ecclésiastiques 1719-1720 ; Froeschlé-Chopard, La religion populaire en Provence orientale p.272

${ }^{813}$ AdAM G 1306 (Fonds de l'Evêché de Vence) Conférences ecclésiastiques 1719-1720, réponse du curé de Saint-Paul, March 1719
} 
preponderance of Latin in the Catholic liturgy to lead to idolatry. In most of the responses, however, the focus was on the practical realities of administering spiritual succour to the inhabitants of the parish. A village priest had to preach the gospel and take confession, which could only be done successfully if priest and penitent understood each other.

While the majority of those who responded to the Bishop's question asserted that the village priest invariably had need of patois in the course of their duties, not all limited themselves to the practicalities of dispensing the holy ministry. A number went further, arguing that the village curé should be concerned with the temporal as well as spiritual welfare of the parish, making knowledge of the local language even more important. The vicar of Hautes-Gréolières, for example, pointed out that it was the vicar's duty not only to 'instruire le troupeau qui luy [sic.] a été confié en luy [sic.] distribuant le pain de la parole de dieu et de luy [sic.] administrer les sacremens [sic.] principalement celuy [sic.] de la pénitence', but also to fulfill the 'fonctions de médecin et de juge'. In doing so he introduced the unmistakeable motif of the bon curé, the village priest concerned above all with the interests and well-being of his flock, to a discussion of the linguistic capacity needed to successfully minister to a parish. However, even though the clergy of Vence asserted the necessity of employing regional languages in the organised worship of the Catholic Church, they did so on the basis that without speaking the language of the people they could not instruct their flocks. They used the local language to bring the religious beliefs and practices of the people into line with the doctrines of Catholicism.

\section{The Episcopate, the Village Curé and the Lay Community- Language, Status and Religion}

The clergy of the diocese of Vence, those at the coal face of Catholic religious worship, embraced the use of regional language as a practical necessity. Without recourse to the local patois, they felt, it would have been impossible to stimulate devotion amongst their flocks. However, this should not obscure the extent to which they themselves may have preferred to make use of the French language, and indeed the issue of language cut across probably the most bitter division in the 
French Catholic Church of the eighteenth century- that between the parish clergy, the curés and vicaires directly occupied with the care of souls, and the episcopate, the almost entirely noble ranks of bishops, vicaires générals and those in receipt of benefices like priories and abbeys without pastoral functions.$^{814}$ Because it was virtually impossible for a commoner to obtain an office above a simple curé in the eighteenth century, and because so little of the spectacular wealth of the Catholic Church found its way into the relatively impoverished hands of the parish clergy, an enormous store of resentment was built up by these men towards their episcopal superiors. ${ }^{815}$ This tension between the parish clergy and the episcopate could take on a linguistic dimension. A nobleman occupying the prestigious office of bishop would generally express himself in the prestigious language of Paris. In contrast a parish curé, an individual who was educated, who spoke French, and who was socially distinct from the agricultural workers amongst whom he likely lives, might still find himself obliged to fulfil his ecclesiastical duties in lowly patois. When the curé of Issole responded to the Bishop of Vence's question in March 1719 by observing that 'on objectera que les seigneurs évêques n'entendent pas ce langage de tous ses diossaisins [sic.] \& que sont les premiers curez de son diossaise [sic.]', he may well have been expressing a sentiment shared by many of his colleagues. ${ }^{816}$

This very same sentiment was expressed in a facetious anecdote related by the Marseillaise Alphonse Fortia de Piles. Writing in 1817, de Piles describes a scene in which the recently arrived Bishop of Marseille, François-Xavier Belsunce de Castelmoron, in conversation at his home, expressed his surprise at the timidity of the young women of the diocese that he had confessed: 'Imaginez-vous que presque toutes s'accusent de s'être laissé baiser les pouces, et ont l'air d'en rougir comme d'un gros péché'. One of his interlocutors, recognising that Belsunce spoke no Provençal, asked the Bishop what he thought the girls had meant by 'pouces'. When the prelate held up his thumbs, he replied 'point du tout, monseigneur; en patois, les pousses veulent dire les tet...,

\footnotetext{
${ }^{814}$ Aston Religion and Revolution pp.14-5

$815 \mathrm{~J}$. McManners, French Ecclesiastical Society under the Ancien Régime : A Study of Angers in the Eighteenth Century (Manchester, 1960) pp.173-81

${ }^{816}$ AdAM G 1306 (Evêché de Vence) Conférences ecclésiastiques, réponse du curé d’Issole, March 1719
} 
ainsi, vous voyez que ces demoiselles ne sont pas si innocentes' ${ }^{817}$ The humour of de Piles fanciful tale, turning as it does on the prelate's ignorance of the language spoken in his diocese, leaves the Bishop a culturally and linguistically isolated figure, redundant in the pastoral management of his diocese because of his inability to understand his charges.

Yet those members of the clergy who were obliged to undertake their duties in the local language may well have found themselves in an invidious position, for the upwardly mobile sections of society desired Francophone eloquence in public pronouncements. Thus, in 1807, the Bishop of Aix wrote to the minister of religion to denounce a 'libellous' pamphlet circulating in the town of Arles. This pamphlet criticised the choice of Easter preacher in the church of St. Trophime, and 'exmoine gascon, connu par les opinions politico-religieuse, qu'il avoit [sic.] puisées sur les bords du Rhin et du Morbihan, et dont il innondoit [sic.] quelques départemens [sic.] méridionaux'. The author of the pamphlet described his 'indignation, lorsque j'entendis un moine grossier, dont l'accent béarnais, la déclamation monotone, les gestes indécens résisteroient [sic.] aux cailloux de Démosthène et aux leçons du Rescius le plus habile. ${ }^{818}$

With the parish clergy caught between the desire to demonstrate status and learning through the use of French, and the need to be understood by the congregation, the language of official religious practice in some parts of France became divorced from the language of popular religious devotion. In the Jura, for example, the same observer who informed the Abbé Grégoire that the clergy preached exclusively in French wrote that 'en quelques maisons de village on priait Dieu en patois, ou du moins on faisait en patois certaines prières' ${ }^{\prime}{ }^{819}$ In 1815 the prefect of the Bouches du Rhône, Christophe de Villeneuve, published a descriptive travelogue of his journey across the valley of Barcelonette in the Basses-Alpes, claiming that 'tous entendent le français [...] et ce n'est guère que

\footnotetext{
${ }^{817}$ A. Fortia de Piles Souvenirs de deux anciens militaires: ou, Recueil d'anecdotes inédites ou peu connu (Paris, 1817) pp.196-7

${ }^{818}$ An F19 5660 Essai sur la chiffonnière d’Arles, par un ancien Théologal de la Métropole

${ }^{819}$ Gazier, Lettres p.203
} 
dans cette langue que se font les prônes, les sermons et les instructions religieuses' ${ }^{820}$ However, while organised religion may have taken place in the national language, popular devotion still took place in Provençal. In 1835, Abel Hugo inserted the following series of questions and responses into the language section of the Basses Alpes entry in his France Pittoresque:

Dem. N. outé auaras passa?

Rép. A la vallé de Josaphat.

D. Qué li trouveras ?

R. Lou mouvais Satanas.

D. Te dira : outé vas?

R. Lou li dirai : Laissa-me passa, mouvais

Satanas, que iou m'en agué adoura Dieou et

la Vierge Maria, lou jou de la Purification.
D. N. Où iras-tu passer?

R. Dans la vallée de Josaphat.

D. Qu'y trouveras-tu?

R. Satan, le mauvais.

D. S'il te dit : Où vas-tu?

R. Je lui répondrai : Laisse-moi passer, mauvais

Satan, que j'aille adorer Dieu et la Vièrge

Marie, le jour de la purification. ${ }^{821}$

According to Hugo, the mothers of the region would wake their children at midnight on the day of the feast of the Virgin Mary. They would pray together until dawn, when they would recite this series of questions and responses.

A similar linguistic divergence between the official religious practices carried out in church under the auspices of the parish clergy, and the religious devotion of the laity outside of church, was evident in the Dauphiné. In the diocese of Gap and Embrun, as in the department of the Basses Alpes to the south, the clergy invariably fulfilled their religious duties in French. ${ }^{822}$ However, the Abbé Jean Gondret, who penned a description of the customs, beliefs and religious practices of the valley of Queyras in the 1850s, noted a series of formulaic, religiously-inflected sayings, which were reproduced by those taking part in various rites of passage. For example, when attending a wake, the visitor would offer 'Dio gardé aquous qué restoun, Dieu garde ceux qui restent' upon entering the house of the deceased. The host would respond, 'Dio gardé il vouestré. Dieu garde les vôtres'..$^{823}$

This aperture, between the language of organized Catholic religion and of the popular religion of the laity, did not result in disaffection with the church. On the contrary, areas like the

\footnotetext{
${ }^{820}$ C. de Villeneuve, Voyage dans la vallée de Barcelonnette (Agen, 1815) p.139

${ }^{821}$ A. Hugo, France pittoresque : ou description pittoresque, topographique et statistique des départements et colonies de la France vol. 1 (1835) p.146

822 Tackett, Priest and Parish p.159

${ }^{823}$ J. Gondret, Moeurs et coutumes des habitants du Queyras au XIXe siècle (Nyons, 1974) p.16
} 
Basses and Hautes Alpes were particularly fervent in their commitment to the Catholic faith.

Villeneuve observed of the Basses Alpes that before the Revolution there had been a surfeit of monks and priests in the region, with families eager to offer up their offspring to the holy ministry. ${ }^{824}$ Gondret exalted the religious fervour of the inhabitants of Queyras, claiming that the effects of the Revolution had been overcome so that by the second half of the 1820 s no woman in the area went longer than three months without confessing and taking communion. ${ }^{825}$ These areas provide a marked contrast with lower Provence, where religious services were far more likely to be in Provençal, and the population was largely indifferent to the ministrations of the church, underlining once again that the linkages between the regional languages of France and a commitment to the organised religious practices of the Catholic Church were frequently tenuous.

The linguistic practices of the clergy in this area also reflected the extent to which the sociolinguistic stratification of French society impinged upon the language of religious worship. During the latter part of the eighteenth century, the Basses and in particular Hautes Alpes had been centres of Richerist-inspired opposition to the episcopate, and a well organised 'revolt of the clergy' took place in Dauphiné in the 1780 s. ${ }^{826}$ It would appear telling that a movement lionising the work of the parish clergy at the expense of their episcopal superiors should be focused on a region where French language preaching had become the norm. Indeed, more generally, it appears that the Catholic Church of the late eighteenth century was far from the defender of regional language and culture that some would imagine a century later. The men who administered the spiritual lives of France's Catholics had recourse to the local patois only when their pastoral duties made it necessary, and in general they appear to have preferred the status conferred by French where possible in their written and spoken practice of religion.

\section{Liturgy, Language and Religious Reform from Revolution to First Empire}

\footnotetext{
${ }^{824}$ Villeneuve, Voyage dans la vallée de Barcelonnette p.140

825 Gondret, Moeurs et coutumes p.10

${ }^{826}$ Tackett, Priest and Parish p.242
} 
As a whole, therefore, the French clergy confronted the linguistic diversity of the French population at the turn of the nineteenth century in an inconsistent and somewhat ad hoc manner. The religious mission of the Catholic Church made it difficult for them to abandon entirely the languages spoken by large numbers of the faithful, yet they as much as any other strata of French society felt the dominance of French over public pronouncements, and the pressure to distinguish oneself through the use of the prestigious national language. Unsurprisingly, therefore, the cataclysmic upheavals experienced by the Church during the Revolution brought the issue of language into broader debates around the reconstruction of religion in France.

With the onset of the Revolution, the Catholic Faith, like so many other areas of French cultural life, suddenly appeared apt for reform. The liturgy of the Catholic Church, and specifically the Latin in which it was performed, were singled out by some commentators as anachronistic and alienating for the faithful. In his letter to Grégoire on the patois of the Aveyron, the former Capuchin François Chabot speculated that 'I'assemblée nationale sentira probablement que la langue française est aussi propre qu'un mauvais latin pour attire l'attention de l'Être suprême'. ${ }^{827}$ For Chabot, this was not simply about the ignobility of prayer in 'bad Latin', he viewed the introduction of a French language liturgy as a means to establish social concord. A centuries-old rift could be bridged as Catholics would be reunited with their Protestant brethren who, he claims, 'ne se seraient jamais séparés de nous si la cour de Rome ne s'était point obstinée à mépriser leurs réclamations les plus justes' ${ }^{\prime 28}$ Along with Latin, Chabot also wanted to see patois banished from the church. He recommended that rural curés preach their sermons in both French and the local language, thereby habituating their parishioners to the national tongue, and preparing the way for patois to be jettisoned entirely from religious practice in the course of a few years. In short, Chabot was just as committed to the linguistic unification of the nation as Grégoire, and he had an almost boundless optimism in the role the church could play, and specifically in the potential of a French language

\footnotetext{
827 Gazier, Lettres p.74

828 Ibid., p. 74
} 
liturgy to unite the nation. As he wrote; 'la liturgie dans une même langue lèvera un obstacle de plus [à l'union civil]'. 829

As Ferdinand Brunot observes, the issue of a French language liturgy became a fraught one within the Church during the Revolution. ${ }^{830}$ François Chabot, whose Revolutionary trajectory took him into the Constitutional church, the convention and finally up the scaffold, was not representative of broader opinion within the Catholic Church. Indeed, although he was not the only voice calling for a French language liturgy during the 1790s, the desire to replace Latin with French remained a marginal preoccupation. In June 1790, a pamphlet entitled 'abus du clergé dénoncé à l'assemblée nationale' appeared. Despite the incendiary title, this pamphlet was in reality a relatively staid plea for the reform of the church. It included a 'Lettre d'un Fidèle à M... curé de ... Membre de l'assemblée nationale sur le culte public', which saw the author indulge in a discussion of church music before turning his gaze toward the liturgy. ${ }^{831}$ The author observed that because the congregation could not understand Latin they had become disinterested in the services of the Catholic church- even the women who faithfully attended mass became bored in the pews. In order to reinvigorate the church the author declared himself willing to risk denunciation as an aristocrat or Jansenist by recommending the establishment of a French liturgy. As he wrote; 'je veux rétablir la piété \& le ferveur parmi les Fidèles. Pour cela je demande bonnement que l'on introduise l'usage des prières \& des Offices en Langue vulgaire' ${ }^{832}$

The constitutional church returned to the issue later in the 1790s. In a move described in detail by Brunot, the Concile Nationale of the Constitutional Church decreed in November 1797 that the 'langue vulgaire' would occupy a far more prominent role in Catholic worship. The vernacular was to replace Latin in all prayers that formed part of the priests' sermons, and in those churches where more than one mass was held on a Sunday a reading from scripture in the vernacular was to

\footnotetext{
${ }^{829}$ Gazier, Lettres à Grégoire p.76

830 Brunot HLF ix pp.371-3

${ }^{831}$ Abus du clergé dénoncé à l'assemblée nationale (Paris, 1790) p.3

832 Ibid., pp.13-14
} 
take place during the first and last service of the day. ${ }^{833}$ This was not simply about making the organized manifestations of Catholicism more accessible for the laity; the Concile National sought to become the eponymous founder of a genuinely national church. It was thus decreed that a new ritual would be drafted, in which the administration of the sacraments would take place in French, while the formulae that accompanied them remained in Latin. The objective was to nationalise religion, and mirrored state driven efforts towards national unification. This became evident in the next article, which stipulated that 'dans les diocèses où des dialectes particuliers sont en usage, les pasteurs sont invités à redoubler leurs efforts pour répandre la connoissance [sic.] de la langue nationale' ${ }^{834}$

The task of drafting the new French rituals of the Church fell to Ponsignon, the vicaire général of the diocese of Versailles, though it would ultimately prove a thankless undertaking. Some of the more modest initiatives to replace Latin in the organised worship of the Church went largely unremarked. In 1798 in the church of Gentilly, near Paris, vespers were sung in French in front of a constitutional bishop without engendering much opposition. ${ }^{835}$ However Ponsignon's French language sacraments, and their preliminary adoption for the dioceses of Versailles, proved too great an innovation, stimulating a lengthy pamphlet dispute described by Brunot. ${ }^{836} \mathrm{~A}$ lengthy denunciation of Ponsignon by Jean-Baptiste Pierre Saurine, the constitutional Bishop of Dax, appeared in the Annales de la religion, the Galican and Jansenist inflected paper edited by prominent figures in the constitutional church. ${ }^{837}$ Saurine began with a lengthy discussion of the council of Trent, cited by the Bishop of Versailles as justification for the administration of the sacraments in French, observing that it had never been intended for the vernacular to replace Latin,

\footnotetext{
${ }^{833}$ 'Décrets du concile national de France, 5 Novembre 1797', Collection des pièces imprimées par ordre du concile national de France (Paris, 1797) pp. 10-2 ; Brunot, HLF pp.374-8

834 'Décrets du concile national' in Pièces imprimée par ordre du concile national p.12

${ }^{835}$ Annales de la religion ou mémoires pour servir à l'histoire du dix-huitième siècle, par une société des amis de la religion de la patrie (1797) p.182 ; cited in Brunot HLF ix, pp.382-4

836 Brunot, HLF ix, pp.386-98

837 J.-B. Saurine 'Avis de l'évêque de Dax sur le sacramentaire français', Annales de la religion vol. 10 (1799) pp.49-96
} 
but merely for vernacular explanations to supplement the liturgy in Latin. He then raised the spectre of France's regional languages being used for the sacraments, necessitating the repeated translation of the liturgy, which could only lead to error:

Comment les peuples qui parlent des langues inconnues à tous les autres, tels que les Basques, les Bas-Bretons, etc. pourront-ils être assurés que le service divin, traduit en leur langue par des particuliers, et non examiné et approuvé par l'église, ne contient aucune erreur capitale, aucune hérésie ? Comment l'église pourroit elle l'examiner, si aucun évêque ne connoît leur langue ?38

Saurine's liturgical conservatism, centred on the troubling, discordant effects of translation, seems to follow Enlightenment handwringing over the pernicious effects of linguistic diversity. Thinkers like Locke argued that political conflict was generated by an inability to grasp the external world satisfactorily through language, for if only the circumstances of the polity could be put into words clearly enough, everyone would surely agree on the correct course of action. ${ }^{839}$ Latin for Saurine was a guarantee of theological rectitude, where translation into other languages would bring only schism, error and heresy.

Ponsignon rebutted Saurine's criticism in his own pamphlet, Apologie de l'usage de la langue française dans l'administration des sacremens. There had never been any question of translating the liturgy into these other 'idiomes particulaires', he claimed. That temptation would be removed by the efforts of the current government, 'qui ne tardera pas à rendre le Français vulgaire dans ces contrées' ${ }^{840}$ However, Ponsignon was in a clear minority within the constitutional church. JeanBaptiste Royer, the constitutional Bishop of Paris, endorsed Saurine's savaging of the project. ${ }^{841}$ The Bishop of Rennes, Claude Le Coz, echoed Saurine in a denunciation penned for the Annales in December 1799 ; 'ce seroit jetter dans l'église de funestes germes de division, lesquels bientôt

\footnotetext{
${ }^{838}$ Saurine 'Avis de l'évêque de Dax' in Annales de la religion p.76

${ }^{839}$ Aarslef Locke to Saussure p.32

$840 \mathrm{~J} .-\mathrm{F}$. Posignon, Apologie de l'usage de la langue française dans l'administration des sacremens (Paris) p.48

${ }^{841}$ Saurine 'Avis de l'évêque de Dax sur le sacramentaire français' in Annales de la religion vol. 10 p.96
} 
seroient multipliés et propagés par l'ignorance ou par la malice des traducteurs' ${ }^{842}$ According to Le Coz, translating the liturgy into Provençal, Languagedocien, Basque and Breton 'seroit blesser les bons sens', for it was far from certain that these languages would ever be suitable for this 'étrange innovation' ${ }^{843}$ The scepticism of Le Coz, who otherwise expressed affection for Breton, his 'mother tongue', underscored the prestige of French. French might possess the requisite dignity for religious worship but the regional languages did not. The strength of opposition to the introduction of the French language into the liturgy of the constitutional church became evident from a letter in the Annales signed by thirteen bishops in support of Saurine's arguments..$^{844}$

While displacing Latin from the church's liturgy may have been too extreme, even for the reform-minded prelates of the constitutional church, the French state under Napoleon still saw the Catholic Church as a tool that might be turned to the creation of a common French culture. Upon coming to power, one of Napoleon's first actions was to begin negotiations of a new concordat with Rome, toppling the already precarious edifice of the constitutional church in the process. This move towards religious conciliation flowed from a pragmatic desire for social order, for an end to the religiously inspired civil conflict of the previous decade. ${ }^{845}$ In part, this more pragmatic attitude to the Catholic Church meant an attempt to re-sacralise governmental authority. State officials were to be given prominence at religious services, leading to the kind of interminable disputes over position and status commonly associated with Ancien régime Versailles. In Grasse, for example, an intense dispute arose between the town's curé and the président of the local tribunal, who wanted to install his own ornate pew in the church in order to engender respect for the law. ${ }^{846}$ However, this did not mean an end to the tensions in church-state relations unleashed by the Revolution. Napoleon saw in

\footnotetext{
${ }^{842} \mathrm{C}$. Le Coz, 'Déclaration des Évêques de la métropole de Rennes, contre l'emploi de la langue vulgaire dans la Liturgie' in Annales de la religion vol.10 p.121

${ }^{843}$ Le Coz, 'Déclaration des Évêques' p.121

${ }^{844}$ Annales de la religion vol.10 p.576

${ }^{845}$ Aston, Religion and Revolution p.321

${ }^{846}$ AdBdR 96 V 16 (Fonds de l'archevêché d'Aix) Culte paroissial an XI-1890
} 
the Church a means of securing civil peace, but only once the primacy of State over Church was secured.

The Organic Articles, implemented in 1802 after negotiations with the Pope had finished, obliged all seminaries to teach Boussuet's four articles of 1682, a particularly strong expression of Gallicanism. In the départements réunis, ecclesiastical institutions all became part of the Gallican church. The regime manifested a strong desire to see religious union follow political union, and the French administrators to whom clergymen now had to answer displayed little tolerance for local particularism, such as the baroque Catholicism of northern Italy ${ }^{847}$ Inevitably, as the state attempted to unify religious practice within its expanded borders language again became an issue.

A crucial step in harmonising Catholic practices and beliefs across the Empire was felt to be the introduction of a uniform catechism, and the state pursued this project with gusto. Previously the catechism used in a diocese to prepare young Catholics for their first communion was a matter decided by the local bishop. Napoleon abrogated this authority to the state, promulgating a Catechisme à l'usage de toutes les églises de l'empire. The new catechism, in addition to a few choice additions about the duty owed by Catholics to Caesar, was intended to bring a degree of conformity and harmony to the Catholics of the Empire, but achieved the reverse. The Imperial catechism sparked resistance across the Empire. ${ }^{848}$ In Belgium, for example, the bitter religious conflict unleashed by the opposition of Corneille Stevens and his followers to the concordat was aggravated by the new catechism, and the Bishop of Namur complained to the Minister of Religion that his authority would be destroyed by any perception that he had meekly acquiesced to an imposition from Paris- especially if it carried the imperial crest and was prefaced by an Imperial decree. ${ }^{849}$ While the insult to episcopal authority sparked a revolt in Belgium, in Italy it was the language that proved unpalatable. In 1808 an Italian translation of the catechism was published in

\footnotetext{
${ }^{847}$ M. Broers, Politics and Religion in Napoleonic Italy: The War Against God (London, 2002) pp.52-4

${ }^{848}$ B. Plongeron, Théologie et politique au siècle des lumières, 1770-1820 (Genève, 1973) pp.278-84

${ }^{849}$ AN F19 5438 (Catéchisme impériale) l'évêque de Namur au Ministre des Cultes, 26 Aug. 1806
} 
Turin, prompting the same fears over imprecision expressed by Saurine in relation to the translation of the liturgy. According to Jacques Raillon, who would be named Bishop of Orléans in 1810 and was charged by the Minister of Religion with examining the translation, the version was not 'aussi exacte qu'elle aurait dû l'être : il y a des additions en plusieurs endroits, et en beaucoup d'autres où il n'y a rien d 'ajouté, la version n'est pas aussi littérale que le permettroit [sic.] le génie de la langue italienne' ${ }^{850}$ In 1811, Pommereux, as Director of the Press, ordered the confiscation of all the old diocesan catechisms still in circulation in Belgium and the Rhineland. Pommereux also expressed concerns over the accuracy of translations of the catechism, recommending that any versions in a different language be authorised by the state and that the French text should be presented in a second column beside the new version, as was the case in those departments where laws were published in a different language. ${ }^{851}$

Given the difficulties in administering a church, and indeed a polity, splintered by linguistic divisions, it is unsurprising that the state put certain members of the episcopate under pressure to expedite the spread of the French language. In March 1805, then Minister of Religion Jean-EtienneMarie Portalis, wrote to the Bishop of Nice and the prefect of the Alpes-Maritimes at the behest of Napoleon following a report that 'dans une des églises de Nice on prêchait le carême en langue italienne'. Portalis seemed to leave scant room for negotiation ; 'il faut [...] que l'enseignement religieux doit se faire, comme tous les actes publics, dans la langue nationale. Telle est la volonté de sa majesté impériale' ${ }^{852}$ However, both the prefect and the Bishop of Nice replied to Portalis urging him to reconsider, and the minister of religion duly addressed a report to the Emperor observing that the preachers for the coming Easter service had already been chosen, that they were incapable of giving their sermons in French, and that replacements could not be found at such short

\footnotetext{
${ }^{850}$ An F 195438 Raillon au Ministre des cultes (n.d.)

${ }^{851}$ An F 195438 Pommereux au Ministre des cultes, 12 apr. 1811

${ }^{852}$ AdAM 2 V 1 (Fonds de la préfecture- cultes) Ministre des cultes au préfet des alpes-maritimes 2 germinal an XII (25 mar. 1805)
} 
notice ${ }^{853}$ Portalis successfully obtained a year-long reprieve from the Emperor, and the relieved Bishop of Nice wrote to the prefect thanking him for his support in front of the Minister. He added that introducing French into the religious instruction of the diocese would be difficult because the majority of his priests did not speak the language, and the majority of the faithful did not understand it. Perversely, the Bishop was led to consider the introduction of a practice imported from France, but perhaps not the one Portalis had in mind, for he resolved to instruct his clergy that, having abjured Italian, those who found themselves in 'I'impossibilité de prêcher en français, qu'ils prêchent en patois, comme l'on prêche partout en Provence et ailleurs' ${ }^{854}$

A year later, in 1806, the state again sought to put the clergy to work spreading French. The Bishop of Metz was instructed to 'invite' his clergy to preach and conduct the catechism in French, or at least in French and German. The Bishop was amenable to the project, responding that 'depuis longtemps j'ai moi-même senti l'importance de rendre le langage uniforme dans toute l'étendue de l'Empire et j'ai employé pour y parvenir tous les moyens qui étaient en mon pouvoir'. However, he encountered a number of obstacles, the most significant of which 'vient de ce qu'un grand nombre de prêtres savent que l'allemand.' This was a difficulty he had attempted to solve at source, by employing 'les moyens les plus convenables pour n'ordonner aucun sujet qui ne sût au moins un peu de français'. ${ }^{855}$ However, his efforts had not yet achieved their desired effect, and the Bishop confessed he would have to reflect along with his vicaires générales on what further measures might be taken. ${ }^{856}$ Similar difficulties were encountered by the Bishop of Nice upon the expiry of his period of grace. This time he was granted leave to allow preaching in Italian until such time as his seminary could furnish him a sufficient number of French-speaking priests. ${ }^{857}$

\footnotetext{
${ }^{853}$ An F19 1076 (Police des cultes) Rapport de Portalis- Permission demandée par les marquilliers de la cathédrale, pour faire prêcher en lalein encore pendant l'année qui va commencer.

${ }^{854}$ AdAM 1 T 4 Enseignement de la langue française, L'évêque de Nice au préfet des Alpes-Maritimes, 19 germinal an XIII (9 Apr. 1805)

${ }^{855}$ An F19 453 (Police des cultes- Moselle) L'évêque de Metz au Min. des cultes 27 Feb. 1806

${ }^{856}$ An F19 453 L'évêque de Metz au Min. des cultes 27 Feb. 1806

${ }^{857}$ An F19 1076 Rapport de Portalis- Permission demandé par l'évêque de Nice pour la prédication en langue Italienne, 25 Jun. 1806
} 
This was neither clerical obstructionism on the part of the Bishops of Nice and Metz, nor did it represent a deeper commitment to regional linguistic diversity, for the promises both men made to pursue other means of spreading French were not idle. Both the seminary at Nice, and the seminary at Metz, were governed by regulations including the sorts of rules on the use of language more commonly associated with the secular institutions of the Third Republic. Article 17 of the regulations for the seminary of Nice, drafted in December 1807, stated that 'le patois est expressément prohibé au séminaire ; on n'y doit parler que les langues français et latin' ${ }^{858}$ In the diocese of Metz, German was not entirely excluded from the seminary, probably reflecting the greater prestige of German compared to the dialects of France, although there was a clear effort to elevate the status of French above that of German. German-speaking priests were obliged to attend French lessons, while for their Francophone peers learning German was optional. However, the starkest indication of which language was to be favoured was to be found within the general disciplinary regulations, which held that 'Il n'est pas permis de parler allemand en récréation, dans aucun des petits séminaires' ${ }^{859}$ Such rules, which went beyond the setting of academic goals for language learning by restricting the use of languages other than French, were intended to create a stigma around the other language, to inculcate a sense of shame amongst speakers who would come to dissociate the language from public contexts and relegate it to the private sphere. That they should be promulgated by prominent members of the episcopate confounds the common expectation that the church was always to be found in the vanguard of resistance to the language policy of the French state.

Of course, Metz had been part of France for several centuries before the Revolution, and Nice had long faced towards France as much as Italy. It was easy for administrators to envisage the assimilation of these areas into a French cultural, as well as political area, easier perhaps than some

\footnotetext{
${ }^{858}$ An F19 819 (Affaires générales du culte- état des séminaires en Piémont) Règlement du séminaire de Nice, 16 Dec. 1807

${ }^{859}$ An F19 3973 (Séminaires : règlements et fonctionnement. An X-1904) Règlemens de grand et petits séminaires du diocèse de Metz, 12 Mar. 1808
} 
of the further flung areas incorporated into the state during the period. As the minister of religion wrote to the prefect of the Alpes-Maritimes in 1805 on the subject of Italian language preaching,

comment se-fait il qu'aujourd'hui dans un département français dont les habitans n'ont jamais cessé d'entendre et de parler notre langue, on se croie obligé d'en employer une autre dans l'instruction religieuse ? [...] votre département a reconnu dans tous les tems qu'il faisait partie du territoire français : maintenant ceux qui l'habitent ne forment avec nous qu'un seul et même peuple, le peuple français [...] il faut que nous soyons désormais réunis par la même langue'. ${ }^{860}$

Evidently this could not be said for the large parts of Northern Italy, the Rhineland, Belgium and the Netherlands that were annexed as départements réunis. If the government could not impose French on the clergy of areas like Nice and Metz, the chances of imposing French on more distant possessions with no history of Francophone literate culture was remote.

The influence of Napoleonic rule on the place of French in clerical life in these areas, to judge by the place the language occupied in the seminaries of northern Italy, varied greatly, and in some places was marginal. In the seminaries at Arezzo, and Borgo San Spolcro, for example, teaching was confined to Latin and Italian. ${ }^{861}$ French was not entirely ignored on the Peninsula, however. The regulations of seminaries in areas that had spent longer under French rule, such as Casal Monferato, Asti, Parma and Turin, all required their students to study French, and held classes in the language for local priests who were unfamiliar with it. ${ }^{862}$ Despite these injunctions, it is unclear how seriously the study of French was taken in these institutions. François-André Dejean wrote to the Minister of Religion in December 1812 outlining the need to reorganise the diocesan seminary. According to Dejean, a good number of the seminary's regulations had become redundant, and, 'j'ai observé aussi qu'une autre partie, dans la suite du temps était insensiblement tombée dans une espèce d'oubli' ${ }^{863}$ It is not clear whether the obligation to learn French was one of the regulations ignored within the

\footnotetext{
${ }^{860}$ AdAM 2 V 1 Ministre des cultes au préfet des alpes-maritimes 2 germinal an XII (25 mar. 1805)

${ }^{861}$ AN F 19818 (Affaires générales du culte- état des séminaires en Piémont) Regolamento per gli studi del seminario Vecovile di Arezzo ; Regolamenti per il seminairo di San Sepolcro

862 An F19 818 (Affaires générales du culte- état des séminaires en Piémont) Projet de Règlement pour le Séminaire de Casal ; Règlement pour le Séminaire d'Asti ; AN F19 819 Règlement des séminaires de Parme et de Turin.

${ }^{863}$ An F19 818 I'évêque d'Asti au Ministre des Cultes, 24 Dec. 1812
} 
seminary, though implementing French language tuition was one of Dejean's aims in reorganising the seminary. As he wrote in the new regulations, 'devenus français, la langue de la nation doit faire désormais une partie essentielle de l'instruction des élèves'. In pursuit of this aim, not only would students be obliged to follow a course in French, they would face an oral examination in the language three times a year..$^{864}$

Dejean may have supported the regime's cultural politics, but he displayed no great urgencythe Bishop had arrived in Asti in 1809. Moreover, Dejean was a French bishop imposed on Asti by the regime, and struggled to command loyalty from his clergy throughout the period. ${ }^{865} \mathrm{His}$ unpopularity as a French imposition might also explain why the previous seminary regulations, which had included an obligation to study French, were treated as an irrelevance. In short, episcopal willingness to support efforts to spread French did not necessarily impact greatly on religious practice. The Bishop of Vercelli probably struck a more realistic note when he flatly refused to impose French language preaching on his diocese in 1809. As he explained, 'Il n'est pas possible d'enseigner en français. Notre enseignement tend à habiliter les élèves pour l'instruction chrétiens des fidèles. Or les fidèles de mon diocèse n'entendent point la langue française'. This was, he asserted, all the more justifiable given that in provinces that had long been part of France, like Alsace and Brittany, preaching and the catechism frequently took place in a language other than French. The need to learn French was clearly experienced as an alien, even unwelcome imposition by the Bishop, a sentiment that became clear when he observed that ' $c$ 'est beaucoup qu'on porte les élèves à lire et à mal bégayer le françois,[sic.] que nous évêque ne parlons même, et n'écrivons que très mal'. However, far graver than the discomfort felt amongst the clergy from the imposition of French would be the impact on the laity; 'ce seroit [sic.] abandonner le peuple, que de leur faire parler français à l'église'. ${ }^{866}$

\footnotetext{
${ }^{864}$ An F19 818 Réglements pour le séminaire d'Asti, Dec. 1812

865 Broers, Politics of Religion pp.94-5

${ }^{866}$ An F19 819 L'évêque de Verceil au Min. des cultes, 26 Jul. 1809
} 
The opposition of the Bishop of Vercelli to the use of French in religious practice reflected a broader struggle that characterised much of French rule in Italy during the Napoleonic period. The French sought not only to rule, but to govern, to reform social, cultural and religious norms so as to render the territories over which they had dominion both more enlightened and more French. ${ }^{867}$ In the parts of Italy under French domination, this effort was problematic for the church. Reforming religious practice and institutions, introducing a new language to religious worship, was not simply a usurpation of episcopal authority, it also threatened to alienate the laity from the church. As a result, the religious policies of the Napoleonic state, and in particular the enduring obsession with clerical oath taking which perturbed the ranks of the clergy as they became subjects of the Empire, functioned as a clarion call to resistance against state authority in the provinces. ${ }^{868}$

Yet while difficulties in Italy inevitably reflected the thorny realities of occupation, such conflicts were in an important sense an iteration of wider struggles taking place across France, not only between state and episcopal authority, but between the officially sanctioned culture of the metropolis, and religious practices considered in some sense peripheral, whether as 'foreign' or 'popular'. While more conciliatory in its attitude to religion than the Jacobin de-christianisers of the Year II, the Napoleonic regime still sought to establish a high degree of centralised governmental control over the church and practices like religious holidays. ${ }^{869}$ The best known consequence of this tussle was the imprisonment of Pius VII at Fontainebleau, although even the ostensibly conciliatory period following the concordat witnessed a degree of religious dissent. In 1804, the government drew up a list of politically seditious priests in the departments of France. ${ }^{870}$ The clergy of some departments, such as the Breton department of Morbihan, the Gers in the south of France and the Rhenish department of the Sarre were listed simply as 'tranquil'. In contrast, other departments, such as the Tarn in Languedoc and the Gascon department of the Landes were signalled as centres

\footnotetext{
${ }^{867}$ Broers, The Politics of Religion pp.4-5

${ }^{868}$ Broers, The Politics of Religion p.151

${ }^{869}$ N. Shusterman, 'Une Loi de l'église et de l'état : Napoleon and the Central Administration of Religious Life' in French History vol.21 no.3 (2007) pp.313-30

${ }^{870}$ An F 195598 (Police du culte) Liste des ecclésiastiques séditieux, 1804
} 
of religious and political dissent, without individual malefactors being named. For most, however, a number of priests were cited individually, along with an outline of their indiscretions, which varied from refusing to acknowledge the authority of the Bishop to outright denunciations of the concordat in writing or from the pulpit. This was accompanied by a decision on precisely what action should be taken against these individuals. Those deemed to pose the greatest threat were exiled to Turin or Rimini in northern Italy. This was the fate of Jean-Joseph-François Costaing, a native of Avignon arrested in the Bouches du Rhone as a 'perturbateur dangereux', who had been arrested with a series of seditious pamphlets including one entitled 'I'antichristianisme ou le soi-disant concordat', which he had penned himself. Others deemed less dangerous, such as the clutch of priests in the Charente Inférieure who, while apparently reconciled to the concordat refused communion with their bishop, were placed under surveillance.

The distribution of these priests, shown in Figure 18, reveals no more concrete patterns than the distribution of resistance to oath taking during the Revolution. Certainly, many of the areas that had seen widespread religious and civil conflict during the Revolution remained problematic for the government, with the west of France in particular offering a disproportionately high number of troublesome priests. Similarly, the lle-de-France and surrounding areas in the Centre and into Lorraine remained broadly untroubled by religiously inflected political dissent. However, adhesion to the concordat frequently reflected not only regional religious culture, but also the character and nature of the episcopal hierarchy in certain areas, and the relationship of the Bishop to his clergy. The difficulties in the Haut Rhin, for example, stemmed from the appointment of the constitutional Bishop of Dax, Jean-Baptiste-Pierre Saurine to the archbishopric of Strasbourg. The resistance of the clergy of the Haut Rhin seem to have been rooted in the perception that Saurine ran his diocese in a 
partisan fashion, favouring juring priests, as much as a principled rejection of a reform-minded constitutional bishop. ${ }^{871}$

If there was to be no repeat of the religious discord that had wracked the nation during the Revolutionary period within 'Old France', these seditious priests remind us that tensions over church-state relations, as well as the nature of the Catholicism which was to be practised, continued throughout the Napoleonic regime. However, the relationship between religious dissent and linguistic diversity was not a straightforward one. In Finistère, ten clergymen were signalled as politically problematic. However, the two other departments with Breton-speaking populations- the Morbihan and the Côtes du Nord- were relatively tranquil, with two curés in the latter department the sum total of religious dissenters. There were hotspots in the south, particularly the Landes and in the Archdiocese of Montpelier, yet much of Provence was comparatively placid. In contrast, the Walloon-speaking Sambre et Meuse, and French-speaking Vendée joined Breton-speaking Finistère as central loci for the activities of the Stevenists and the Petite Église, while much of the German speaking Rhineland and Flemish-speaking Belgium was untroubled.

This is not to say that the issue of language was unconnected with the issues surrounding the reform of Catholic practice and the relations between Church and State that characterised the period. The state viewed promulgating the French language within the practice of the church as a way of forging a broader national community. The numerous seminary regulations which included articles necessitating the teaching of the French language, along with the evidence of direct ministerial interventions on the subject indicate a fairly consistent policy in this regard, even if short term exceptions had to be made in some areas. Yet these disputes over the language of religious instruction interacted in a complicated way with the more general efforts towards the reform and management of religious practice pursued by the regime during the period.

${ }^{871}$ AdHR V 60 (Opposition entre l'évêque et son clergé) Maire de Landser au sous-préfet d'Altkirch, 6 messidor an $X(25$ June 1802) 
Resisting the use of French did not necessarily reflect a broader hostility towards the regime or French rule in particular. Grimaldi, the vicaire général of Nice who had consistently petitioned the government to allow the preaching in the Alpes-Maritimes to continue in Italian, was not implacably opposed to reforms to Catholic practice, even those emanating from Paris. In 1808, he wrote the minister of religion advocating that the Imperial catechism be complemented with a unified liturgy that could serve for every diocese in the Empire. As he suggested, 'Votre excellence jugeroit [sic.] peut être utile, de prescrire un bût semblable aux rédactions d'une liturgie, qui après avoir été approuvée par sa majesté et par sa sainteté, pût devenir commune à toutes les églises de l’empire françois [sic.] ${ }^{872}$ Yet while Grimaldi supported the idea of a liturgy compiled and authorised by the state, his remarks on language revealed the bind in which reform-minded members of the clergy found themselves. According to Grimaldi, the Roman ritual governing ceremonies such as marriage and baptism, still in use in many of the dioceses of France, was too often an obstacle to the faithful who rarely spoke Latin. Grimaldi argued that 'leur piété trouveroit [sic.] un utile secours, dans les courtes instructions en langue vulgaire contenues dans divers rituels particuliers à certains diocèses' ${ }^{873}$

While this solution was hardly radical, the Council of Trent settled on the same remedy, it reveals that Grimaldi was not opposed in principle either to state-driven reform or the use of the vulgate in church. Rather, the issue was which language was to be considered the vulgate, which might actually enhance the participation of the laity in religious ceremonies. The issue of language within the church during the Napoleonic period might thus be understood as a process of conflict between three distinct parties: the officially sanctioned and promulgated metropolitan culture of Paris; the divergent preferences and religious practices of the faithful; and the clergy. The members of the clergy were themselves divided over the legitimacy of the Napoleonic regime, and the desirability of reform to religious institutions. Many bishops were caught between, on the one hand,

${ }^{872}$ An F19 1076 Grimaldi, vicaire général du diocèse de Nice, au Ministre des cultes, 18 Nov. 1808 873 Ibid. 
government authorities that sought to use the church as an instrument to make the population more French and society better ordered, and the preferences of their flocks on the other. More than this, however, they were themselves torn between didactic impulses and the church's spiritual mission- between the desirability of reform and the need to speak to the people.

\section{Religious Dissent and Linguistic Conformity- The Case of Alsace}

Religious communities were, therefore, forced to negotiate these complex tensions between the nation-building efforts of the state and their own religious and linguistic particularities. This was, however, not a straightforward struggle between the partisans of regional culture and reforming central authority. Local religious and political elites were often pro-French in their linguistic attitudes. They were invested simultaneously in their own religious practices and in the French state and national culture, which could grant cultural capital along with political and social power, and as a result the politics of religion often unfolded in a complicated pattern of accommodation and resistance. There is no better case study for such a process than the confessional and linguistically divided Alsatian department of the Haut Rhin.

During the Napoleonic period, the Haut-Rhin was a complex agglomeration of territory, not all of which had belonged to France before the Revolution. The predominantly German-speaking rump of the department had formed 'upper' Alsace before the Revolution, along with the mainly French-speaking area to the South which today forms the Territoire de Belfort. To this was added, in 1798, the German-speaking and resolutely Calvinist republic of Mulhouse, and in 1800 the linguistically mixed territory of the Swiss districts of Biel and Délémont. The department was also home to fairly substantial religious minorities. A survey carried out by the prefect in 1837 , which of course excluded the Swiss territory detached from France after the fall of Napoleon, gave a figure of 46,311 Protestants and 10,643 Jews from a total population that numbered 424,258 according to 
the 1836 census. ${ }^{874}$ Moreover, these religious minorities were largely urban and wealthy. According to a report written by the prefect in 1821 , the Protestant communities of the department were 'plus laborieux, plus instruits, plus riches' than the Catholic ones. ${ }^{875} \mathrm{~A}$ study carried out by the prefect in 1817, of the religious populations of Colmar, Mulhouse, Ribeauvillé and Ste Marie aux Mines found that of the 36,244 inhabitants of these four towns, only a little over half were Catholics. ${ }^{876}$ As the figures in Table 9 show, the mayors of these four towns claimed just over 16,000 of the inhabitants were Protestants, split roughly evenly between the Lutheran and Calvinist churches, with just under a thousand Jews and a handful of Anabaptists. Given the figure of 46,000 Protestants in the department twenty years later, it seems that at least a third of the Protestant population at least lived in these four towns even if we assume no growth in the Protestant population between 1817 and 1836.

Table 9 - Population of the towns of Colmar, Mulhouse, Ribeauvillé and Ste Marie aux Mines by Religious Confession, 1817

\begin{tabular}{|l|l|l|l|l|l|l|}
\hline $\begin{array}{l}\text { Noms des } \\
\text { communes }\end{array}$ & Catholiques & Luthériens & Calvinistes & Anabaptistes & Juifs & Total \\
\hline Colmar & 9117 & 4596 & 0 & 0 & 247 & 13960 \\
\hline Mulhouse & 1979 & 1008 & 6076 & 18 & 266 & 9347 \\
\hline Ribeauvillé & 3661 & 805 & 13 & 24 & 391 & 4895 \\
\hline $\begin{array}{l}\text { Ste Marie } \\
\text { aux Mines }\end{array}$ & 4100 & 1810 & 1972 & 150 & 10 & 7042 \\
\hline Totaux & 18858 & 8219 & 8061 & 192 & 914 & 36244 \\
\hline
\end{tabular}

The presence of a large and socioeconomically significant Protestant population in a majority German-speaking population on the borders of the territory of France made Alsace a focus for the anxieties of French administrators and politicians of all stripes who feared secessionism and political dissent. These fears were typified by a report drafted by the prefect of the Haut-Rhin in December 1853, outlining public reactions to the establishment of the second Empire. According to the prefect,

\footnotetext{
${ }^{874}$ AdHR V 1 (Recensement des populations des trois cultes) Recensement de 1837 ; Statistique de la France, (2 vols., Paris, 1837) i, p.190

${ }^{875}$ Ad F1 C III Haut Rhin 7 (Ésprit public) Compte annuel sur la situation du Haut Rhin, 1821

${ }^{876} \mathrm{AdHR} V \mathrm{1}$ (Recensement des populations des trois cultes) État de la population des villes de Colmar, Mulhause, Ribeauvillé et St. Marie aux Mines sous rapport des différents cultes que les habitants y professe, 30 Août 1817
} 
the biggest difficulty stemmed from the wealthy Protestant communities of the region, who were committed to what they saw as the Protestant-friendly constitutional monarchy toppled by the Revolution in 1848 and the abdication of Louis-Philippe d'Orléans. With little prospect of a return of the previous regime and 'en désespoir de cause, les dissidens les plus exaltés, pour lesquels la France c'est le Catholicisme, voudraient détacher l'Alsace du territoire' ${ }^{877}$ The prefect claimed that language was an intrinsic part of this political separatism, for it not only aggravated the separation of the German-speaking Protestant population from the French nation, it gave them common cause with the Catholic and German-speaking majority. As he wrote, 'Il est certain que le protestantisme pousse à cette séparation ; il favorise par tous les moyens qui sont en son pouvoir la langue et les habitudes allemandes, et chercher par des voies détournés à faire des prosélytes, parmi la population catholique et surtout parmi les enfants'.

Such anxieties were not novel in the 1850s. During the Terror of the year II, for example, spreading the French language in Alsace was a preoccupation of Saint-Just in his capacity as representative on mission. ${ }^{878}$ Yet it is unclear how far this perception of a tripartite complex of the German language, Protestantism and secessionism reflected reality. It is certainly true that the Protestant population of the Haut Rhin was largely German-speaking. According to the survey of the religious populations of the Haut Rhin carried out by the prefect in 1831, the Protestant population was concentrated in Mulhouse and the German-speaking north of the department around the capital Colmar. To the south, the predominantly Francophone arrondissement of Belfort was entirely Catholic, and the only Francophone Protestant communities to be found in Ste Marie aux Mines in the north-western corner of the department. However, the Protestants of the Haut Rhin were not a homogenous community, split as it was between Calvinists and the Lutheran confession of Augsbourg. As Table 9 shows, the Protestants of Colmar were exclusively Lutheran, with the former republic of Mulhouse dominated by Calvinists and St. Marie aux Mines split more or less evenly

\footnotetext{
877 An F 1 c III Haut Rhin 7 Rapport du préfet sur la situation politique du départment,19 Dec. 1853

${ }^{878}$ H. F. Schiffman, Linguistic Culture and Language Policy (London, 1996) pp.136-7
} 
between the two churches. These two churches had distinct organisations, and while sometimes treated by the administration as a single group, retained their identities as distinct confessional communities. Thus when, in 1804 , rumours circulated that a single pastor for both communions in Ste Marie aux Mines was to be appointed, the prefect received a petition in favour of the 'église réformée française de Ste Marie', claiming that 'la française qui existe depuis Calvin mérite la préférence, c'est elle qui a fait bâtir le temple qu'elle louoit [sic.] aux allemands depuis une centaine d'années que ceux si se sont établis à Ste Marie'. ${ }^{879}$ The prefect responded a week later that he had received no official communication on the subject, yet the designation of the two churches, Calvinist and Lutheran as 'French' and 'German' respectively was telling- the Francophone Calvinists of the department apparently considered themselves French, as distinct from the German Lutherans of the same town.

In general, the linguistic and confessional divides of the Haut Rhin correlated no better than in the rest of France. German was just as prominent within the Catholic clergy as the Protestant. In 1803, a series of machinations erupted around the appointment of a new curé for the parish of Rougemont in French-speaking Belfort. The mayor of neighbouring Leval denounced the mayor of Rougemont for spreading rumours about the new curé in an effort to get his favourite, an ecclesiastic named Thammer, appointed to the position. According to accusations of the mayor of Leval against his counterpart from Rougemont,

Ce maire instrementeur [sic.] des projets du citoyen Thammer a fait rédiger une nouvelle petition qu'il porte signer de main en main, en disant aux paroissiens que le desservant que M. l'évêque a nommé est un vieillard de 90 ans qui ne connoit [sic.] pas même la langue française, qu'il faut en demander un autre ; dans cette pétition se trouve le nom du citoyen Jacques Thammer' ${ }^{880}$

\footnotetext{
${ }^{879}$ AdHR V 499 (Culte protestant- nomination des pasteurs) Peyre au préfet du Haut-Rhin, 23 fructidor an 12 (10 Sept. 1804)

${ }^{880}$ AdHR V 61 (Culte Catholique) Maire de la commune du Val au préfet du Haut Rhin, 12 brumaire an XII (4 Nov. 1803)
} 
The object of these rumours, a M. Gobert, desservant of Saint Léger in the canton of Dannemarie, was indeed the intended occupant of the curé of Rougemont. ${ }^{881}$ When the ministry of the interior drew up a linguistic map of the department in 1806, St. Leger found itself just on the Germanspeaking side of the line, although this tells us little about Gobert's capacity to speak French. The linguistic border was not absolute, and French speakers were to be found on the German side. Dannemarie, the cantonal chef lieu situated to the north-east of St. Leger, petitioned the Bishop of Strasbourg for a Francophone vicar in 1823, indicating some kind of audience for religious practice in the language. ${ }^{882}$ The plausibility of these rumours probably rested on the predominantly Germanspeaking character of the clergy of the Haut Rhin. In 1814 the curé of Bennwihr wrote to the prefect complaining that the mayor of Mittelwihr, a commune he was also required to administer, had taken to organising the singing of Vespers without the presence of a priest, a practice expressly prohibited by the Bishop of Strasbourg. The curé apologised for making such a complaint by letter, explaining that 'depuis longtems [sic.] le soussigné desservant de Benwir, auroit [sic.] desiré de vous présenter personnellement ses respectes et de vous porter ses plaintes sur différents objets, mais ne possédant point assez la langue française, il ose vous les exposer par écrit' ${ }^{883}$ The curé of Bennwir was not the only member of the clergy of the Haut Rhin who struggled in French, at least to judge from the apparent lack of French speaking priests in the department. In 1832, the Bishop of Strasbourg confessed he had been unable to fulfil a request for a resident curé from the commune of Croix in the arrondissement of Belfort due to a lack of French speaking clergy; ' $j$ 'ai toujours regretté que la pénurie des prêtres françaises ne m'ait pas permis depuis longtemps de satisfaire à son vœu' ${ }^{884}$ Other communes, with larger populations, he wrote, were in more pressing need of these French speakers.

\footnotetext{
${ }^{881}$ AdHR V 61 Sécretaire de l'évêché de Strasbourg au préfet du Haut Rhin, 29 vendémiaire an XII (20 Oct. 1803)

${ }^{882}$ AdHR V 62 (Culte Catholique) Préfet du Haut Rhin à l'évêque de Strasbourg, 23 Jun. 1823

${ }^{883}$ AdHR V 218 (Organisation et police du culte) Curé de Riquewhir au préfet du Haut Rhin 9 Dec. 1814

${ }^{884}$ AdHR V 62 Évêque de Strasbourg au préfet du Haut Rhin 8 Mar. 1832
} 
While the Catholic clergy of the diocese of Strasbourg may have remained largely Germanspeaking, this did not mean that the French language failed to penetrate religious practice in the German-speaking areas of the department. The desire for a French language vicar in Germanspeaking Dannemarie demonstrates a fairly obvious vector of diffusions- proximity to French speakers. However, it is not clear whether the audience for French language religious practice in Dannemarie stemmed from migration or the adoption of French by those who previously spoke German. Proximity was not the only factor that might determine a preference for religious services in French,however. The Catholic congregation of the departmental capital, Colmar, developed a taste for religious preaching in the language when a preacher from Belfort was brought into the town to help celebrate the coronation of Napoleon. This preacher was so successful that it was decided to appoint him permanently as a vicar to the town to lead religious services in French, with the parish council writing to the prefect in April 1804 that,

l'auditoire nombreux qui se trouve chaque fois aux sermons de M. Bourier de Belfort appelé en cette ville pour les tems du jubilé donne à connoitre [sic.] de quelle grande utilité seroit[sic.] dans la paroisse un prédicateur françois [sic.] permanent[...]M. le curé à proposer à $M$. Bourier une place de vicaire chargé spécialement du sermon et de l'instruction en langue françoise' .885

Unsurprisingly, it was the departmental capital, with its French institutions and administrators, in which this enthusiasm for French language Catholic instruction was evident.

If the success of Bourier reflected a desire for Francophone religious instruction in Colmar, it should be recognised that this desire was not confined to the Catholic congregation. In 1811, a service in French was established at the Lutheran church in Colmar, with a priest specially charged to preach in the language. In April 1856, the director of the church complained that this service had suffered after it had been divided amongst the German-speaking pastors of the church, and called for the appointment of a dedicated French preacher. It is worth noting, however, that the principle of a French language service- described by the director as a 'véritable besoin' in a town such as

${ }^{885}$ AdHR V 62 Extrait du régistre des déliberations du conseil de la fabrique de l'église paroissiale de Colmar, 13 germinal an XII (3 Apr. 1804) 
Colmar- endured into at least the Second Empire. ${ }^{886}$ It seems, therefore, that the Lutheran population of Colmar was not implacably opposed to the use of French in a religious context, although they did remain fiercely attached to German. German was still a central part of the religious practice of the Lutheran community, as a memoire to the rector of the academy of Strasbourg in favour of the re-establishment of the Lutheran gymnasium in Colmar, written in late 1817 made clear. The author of this memoire, M. Metzger, one of the members of the consistoire de Colmar, observed that 'les livres saintes traduites en langue allemande par Luther sont entre les mains de chaque famille. Le culte se célèbre en allemande, qui est l'idiome de l'Alsace, sa connoissance [sic.] et l'étude de cette langue devient donc nécessaire, elle doit servir de bas à toute instruction'. This reality led the Lutherans of the department to shun the secondary schools overseen by the state; 'le défaut d'enseignement de cette langue dans les collèges et les lycées, est un des grands motifs, qui retiennent les parens [sic.] à les faire fréquenter par leurs enfants' ${ }^{\prime} 87$

Within their own schools, however, the Lutherans of Colmar were keen to see French taught. Following the establishment of the Imperial University in 1808, the parish school of Colmar was obliged to stop teaching Latin in order to avoid the retributions due to the University by 'secondary' institutions that taught the language. According to the letter drafted by the consistoire, the teaching at this school 'se borne à l'enseignement de la religion, des langues française et allemande, des premières règles du calcul et de l'écriture'. ${ }^{888}$ The recteur of the Académie de Strasbourg, the local official responsible for the oversight of education under the authority of the Imperial University, accepted that Latin was not taught at the school, but was more sceptical about the claim that French was. He wrote to the president of the consistoire de Colmar, asking him to 'faire très particulièrement soigner dans cette école l'enseignement de la langue française conformément aux ordres de sa majesté l'Empereur', and warning that his inspectors would be

\footnotetext{
${ }^{886}$ AdHR $101 \mathrm{~J} 1406$ (Fonds du consistoire de Colmar- diverses) Directoire de l'église de la confession d'Augsbourg au mm. Le président et membres du consistoire de Colmar, 10 Apr. 1856

${ }^{887}$ AdHR $101 \mathrm{~J} 1704$ (Fonds du consistoire de Colmar- écoles) Mémoire sur le gymnase de Colmar, dec. 1816

${ }^{888}$ AdHR 101 J 1701 (Fonds du consistoire de Colmar- écoles) Projet de lettre au préfet du Haut Rhin
} 
tasked with examining the school's progress. ${ }^{889}$ Despite this scepticism, however, it is worth noting that the pastor directing the school, M. Mackler, was also the French preacher appointed in $1811 .^{890}$ Hitschler, who was president of the consistoire of Colmar from at least 1825 into the 1840s, certainly did not set himself against the spread of the French language. Rather, he seems to have felt teaching French to his flock a part of his role. Noting that the only teacher capable of providing instruction in French had an accent in the language, he sought the appointment of a French institutrice to the parish school. ${ }^{891}$ Similarly, in 1829 , the consistoire resolved that 'dans les classes supérieures des garçons \& des filles, M. les instituteurs sont tenus à parler la langue française avec leurs élèves'. ${ }^{892}$

The decisions taken by the consistoire of Colmar reflected a general trend in the Lutheran church in Alsace during the period. In 1839 the consistoire général determined that all church records would be kept in French, rather than German, allowing not only a uniformity in the documentation of the church, but greater facility in correspondence with the civil authorities, 'la langue française étant la seule officielle du pays' ${ }^{\prime 89}$ The authors of this regulation felt it necessary to address concerns specifically about the population of the countryside who, it was felt, might struggle in French; 'en vain, objecterait-on, qu'à la campagne il peut se trouver des membres laïques de Consitoires qui ne seraient pas suffisamment au courant de la langue française et à l'égard desqules il y aurait lieu de maintenir l'ancien usage des délibérations en langue allemande'. ${ }^{894}$ This should not pose any difficulties, according to the consistoire, for meetings could still take place in German, only the procès-verbal and any written documentation would need to be in French. Since this was already the case for official acts such as birth and marriage certificates, it should not prove difficult to find someone capable of drafting reports in French. The consistoire denied this amounted to an attack on

\footnotetext{
${ }^{889}$ AdHR 101 J 1701 Recteur de l'académie de Strasbourg au directeur général du consistoire de Colmar, 23 Apr. 1812

${ }^{890}$ AdHR $101 \mathrm{~J} 1406$ Directoire de l'église de la confession d'Augsbourg au mm. Le président et membres du consistoire de Colmar, 10 Apr. 1856

${ }^{891}$ AdHR $101 \mathrm{~J} 1710$ Rapport du pasteur Hitschler au consistoire

892 AdHR 101 J 2706 (Fonds du consistoire de Colmar- diverses) Séance Consistorale du 12 Jan. 1829

${ }^{893}$ Recueil officiel des actes du consistoire général (Strasbourg, 1841) pp.173-4

${ }^{894}$ Recueil officiel des actes du consistoire général p.173
} 
German, claiming it was simply a reflection of the need to produce French language documentation when interacting with the Francophone institutions of the French state.

Ce n'est pas, Messieurs, que nous songions à assigner un rang inférieur à la langue allemande qui restera toujours essentielle dans les départements du Rhin et qui sera enseignée dans les écoles et cultivée comme elle l'a été dû l'être jusqu'ici [...] Mais la langue françaises étant seule admise pour les actes officiels, il est important qu'il y ait uniformité sous ce rapport. ${ }^{895}$

The German-speaking Lutherans of Alsace, therefore, seem to have retained a connection to German, whilst at the same time recognising that progress meant embracing, to some extent at least, the French language. In short, they recognised that membership of the French nation made French unavoidable, and sought to forge a kind of middle way, a bilingualism that would enable them to both belong to the French nation yet retain their cultural orientation towards Germany. In this vision, described brilliantly by David Bell, Alsace was to be a kind of intermediate ground between the two nations. ${ }^{896}$

This marked an important similarity between the experience of the Lutherans of Alsace with those of other confessions and other parts of France. The increasing presence of the bureaucratic state was evident. Decisions to teach French in the parish school or to draft minutes and correspondence in French may not have been compelled by the state, but interactions with state officials certainly entered into the equation. Using the French language was understood as part of the process of social 'improvement'. Drafting minutes in French, for example, was assumed to improve efficiency by avoiding the need to translate correspondence or keep double records in each language. Similarly, Hitschler's enthusiasm for a new French institutrice in Colmar was driven not only by a recognition of the need for French language instruction. He also extolled the knitting classes she might teach, exclaiming to the members of the consistoire 'combien il est du devoir

\footnotetext{
${ }^{895}$ Recueil officiel des actes du consistoire général p.174

${ }^{896}$ Bell, 'Nation-Building' p.489-90
} 
d'une bonne mère de famille de savoir tricoter et coudre, devoir forcé, mais si souvent négligé par ignorance, surtout dans la classe du bas peuple'. ${ }^{897}$

The principle that embracing the use of French represented one of the primary duties of a clergyman to his flock was embodied in the work of perhaps the most famous Alsatian Lutheran of the Revolutionary and Napoleonic period, Jean-Frédéric Oberlin. In 1767, Oberlin was appointed pastor of Waldbach in the Band de la Roche, a small and impoverished Lutheran valley surrounded by Catholics on the border of Alsace and Lorraine. Oberlin set about improving the lot of his parishoners, primarily through a transformation of the education on offer to them, often paying teachers from his own pocket and earning a nationwide reputation for his efforts, with articles written about him in the Journal d'éducation and school inspectors rhapsodizing about his success. ${ }^{898}$. A central part of this project was spreading French amongst his parishoners, who had previously spoken the 'patois' or dialect of French known as Welche. As he wrote to the Minister of the Interior in 1807, when questioned about the local patois as part of the enquiry into the languages of the French Empire being run by the Bureau de la statistique, 'quoiqu'il y ait 40 ans passés (depuis 1767) que je deserve cette paroise, je ne comprends rien, lorsque j'entends parler mes paroissiens entre eux en patois. Mais aussi en ma présence on ne parle jamais patois, et dans beaucoup de familles on ne parle plus patois avec les enfants. ${ }^{\prime 899}$ This principle was, according to one British observer of Oberlin's work, extended to the schools he oversaw. As she wrote of the girls' infant school, the teachers 'never permitted them to speak a word of patois [...] by this means correct French was introduced into the Ban de la Roche, and the patois, [...] partly abolished'.$^{900}$

On the issue of language, therefore, the Lutheran pastors of Alsace found themselves in much the same position as their Catholic colleagues. The distinctly Enlightenment model of

\footnotetext{
${ }^{897}$ AdHR $101 \mathrm{~J} 1710$ Rapport du pasteur Hitschler au consistoire

${ }^{898}$ 'Sur les écoles de la paroisse de Ban de la Roche, dans le département de Bas-Rhin' in Journal d'éducation 1806 pp.245-50 ; AN F 179368 (Instruction publique) Rapport de l'inspecteur de l'académie de Nancy, 1829 ${ }^{899}$ An F17 1209 J.F. Oberlin, 'Observations'

900 L.S. Atkins-Wilson, 'Memoires of John Frederic Oberlin : Pastor of Waldbach in the Ban de la Roche (Pittsburgh, 1832) p.75
} 
education and improvement called for the language used by individuals to be regulated and corrected- and above all had to be French. This was perhaps most obvious in an area like Ban de la Roche where French competed with a 'patois', yet even amongst the Lutherans of Alsace, reticent to cede the status of their German language to French, the language of the nation was making inroads. Indeed, it is striking that the pattern of French language religious instruction should cut across confessional lines in Alsace, with Colmar, the departmental capital, as the epicentre and the smaller rural congregations felt to lag behind in German monolingualism. Yet if the language of religious practice was a function of societal linguistic demands- of how much education the laity might bearthe influence of the state should not be ignored. Certainly, as Oberlin demonstrates, language was implicated in a religiously inflected notion of educating the laity well before the Revolution, yet it is striking not only that French language preaching in the German areas should emerge amongst both Catholic and Protestants in the same town, but that it should do so at the same time. The pressure of the French state and the establishment of centralised, Francophone institutions that emerged during the Revolutionary and Napoleonic periods were thus crucial. In the words of the président de la consistoire général, it was these institutions which, however slowly, made French 'la seule langue officielle', and the gradual spread of the use of French within religious practice and institutions was the inevitable result.

\section{Re-Christianisation and Regional Languages}

Above all, it is clear that during the Revolutionary and Napoleonic period, the religious institutions of France were not the bastions of linguistic conservatism they would become under the Third Republic. For the most part, and especially in those parts of France where one or the other 'patois' was spoken, the use of the local language seems to have been considered a necessary part of preaching to the 'people' rather than a bulwark against secularism and irreligion in itself. Paradoxically, this is revealed in the work of Eugène de Mazenod, the pioneer of Provençal language missionary preaching in restoration France. Born into a noble family in Aix, Mazenod spent much of his childhood in exile in Italy. He returned to France under the Empire and studied at the seminary of 
Saint-Sulpice in Paris, and was ordained in 1811. Following the fall of Napoleon, Mazenod took up what was to become a prominent role in efforts to rechristianise the country, founding a group of missionary preachers in Aix- the 'Missionaires de Provence'. Outlawed under Napoleon, Catholic missions, which were necessary to fill in the gaps left by an elderly and undermanned clergy, became a feature of the religious life of restoration France, often to the consternation of local government officials and clergy alike. Officials were concerned about public disorder surrounding missions, while the many local clergymen feared losing authority over their congregations. Such concerns were only exacerbated in 1819 by the riots that gripped Brest when the imminent arrival of a group of missionaries became known. Songs decrying the missions for their 'anti-enlightenment' activities, for burning copies of Voltaire and Rousseau, and most gravely for turning women against their menfolk, circulated in the town. As one, entitled simply 'La Mission', read:

En tous les lieux où prêchent ces bons pères, On ne voit plus un seul ménage uni ; La femme ici fait au mari la guerre,

Elle est ailleurs battue par son mari. ${ }^{901}$

The mission itself had to be abandoned when a crowd of 'citoyens aisés et de pères de famille' more than two thousand strong assembled and marched through the town, crying 'vive le Roi ! et à bas la mission!! ${ }^{902}$

The activities of the Catholic missions under the Restoration, and most notably their book burning have been well documented. ${ }^{903}$ Mazenod, the pioneer of Provençal language preaching, was in the vanguard of this conservative, and controversial, brand of Catholicism. Mazenod himself drew complaints in December 1818 when, at the head of a mission to Bajoles in the Var, he refused burial to a woman suspected of Jansenism. He was also accused of overseeing a three hour night-time vigil in the cemetery, in which sermons on the subject of death were accompanied with a display of the

\footnotetext{
${ }^{901}$ An F19 5555 (Police du culte- Missions) La Mission, Chanson Chrétienne

${ }^{902}$ An F19 5555 Sous-préfet de Brest au Min. de l'Int. 26 Oct. 1819

${ }^{903}$ M. Lyons, 'Fires of Expiation : Book Burnings and Catholic Missions in Restoration France', French History vol.10 no.1 (1996) pp.1-27
} 
severed head of a recently deceased corpse, complete with hair and apparently still recognisable. ${ }^{904}$ The activities of the Missionnaires de Provence reflected the wider return of the Jesuits and Jesuit missionary practice to France under the restored Bourbon monarchy. ${ }^{905}$ Both the Jesuits and missionary preaching were banned under the Revolutionary and Napoleonic regimes, and their return was controversial. ${ }^{906}$ Perhaps unsurprisingly, Mazenod was obliged to leave the department under threat of prosecution. ${ }^{907}$

Mazenod founded the Missionaires de Provence in 1814 in the hope that they might 'instruire le peuple, surtout celui de la campagne, en langage provençal' .908 The impulse emerged from a fervent, reactionary and self-consciously anti-enlightenment Catholicism which sought to save souls they felt had been abandoned during two and a half decades of spiritual neglect. This effort manifested its own particular didacticism, disconnected from the ambition to make 'the people' better Frenchmen, or even better educated, and focused singularly on making them better Catholics. Shorn of any attachment to the projects of nation building or educational reform that influenced more moderate churchmen, Mazenod embraced Provençal in his efforts to proselytise amongst the people of his native Provence.

The centrality of language to Mazenod's endeavours became clear in 1817, when it appeared the Missionaires de Provence might be forcibly incorporated into the larger Missionaires de France. Mazenod travelled to Paris to make representations in person, armed with a letter from the Baron de Damas. According to Damas,

I'objet particulier du voyage de M. de Mazenod est d'obtenir que les Missions de Provence, ne soyent [sic.] pas réunies à celles de France, parce que la langue du pays diffère totalement de celle du reste du Royaume, et que le peuple n'entend pas cette dernière. Je

\footnotetext{
${ }^{904}$ An F19 5555 Commissaire du police du Var au préfet, s.d.

905 G. Cubitt, The Jesuit Myth : Conspiracy Theory and Politics in Nineteenth Century France (Oxford, 1993) pp.59-60

906 Cubitt, Jesuit Myth p.62

907 An F19 5555 Min. de l'Int. au préfet du Var, 23 Dec. 1818

${ }^{908}$ An F19 5555 État du personnel- missionnaires de Provence
} 
suis persuadé que des prêtres étrangers à ce pays, ne produiroient [sic.] point sur le peuple, le même effet, que les prêtres du pays, à cause de la langue' ${ }^{909}$

The mayoral office in Aix, perhaps motivated by a series of disputes that had arisen between the missionaries and the clergy of the town over their right to perform first communion for children in the town, was less supportive. ${ }^{910}$ Making reference to Mazenod's oft-repeated claim that their capacity to preach in Provençal made their independent existence crucial, the adjunct of the mayor of Aix wrote that 'si des missions sont nécessaire on peut recourir aux missionaires de France qui ont parmi eux des sujets de toutes les provinces et qui connaissent leurs divers idiomes'. ${ }^{911}$ Yet the linguistic particularism upon which Mazenod based his claims was not an idle one. In a letter to Abbé Forbin-Jansen, one of the most prominent members of the sociéte des missionaires de France, Mazenod wrote that 'ce serait les abandonner que de nous joindre à vous, parce que nous seu[ls], et non pas vous, pouvons leur être utiles. Il faut parler leur [propre] langage pour être etendu d'eux ; il faut prêcher en provençal'. ${ }^{912}$

Mazenod's claim, that one must preach in Provençal in order to reach the people, and that this required a separate group of missionaries dedicated to the task, reflected the significant investment in time and effort required to undertake religious preaching. Preaching, particularly of the sort practiced by missionaries, was a vocation in itself. Parish curés might have managed Sunday sermons, but professional preachers were often brought in for the important ceremonies of the year, particularly in larger towns and cities, at great expense to the diocese and as the disputes between Paris and Grimaldi over Easter preachers in Nice shows, often in the teeth of state opposition. Missionary preaching also required a repertoire of sermons, and the absence of such a collection forced Mazenod to decline an invitation from Forbin-Janson in 1815 to take part in a mission in Marseille:

\footnotetext{
909 An F19 5555 Damas au Min du culte

${ }^{910}$ An F19 5555 Adjoint du maire d'Aix au Min. de l'Int. Sept. 1817

${ }^{911}$ An F19 5555 Adjoint du maire d'Aix au Min. de l'Int. Sept. 1817

912 'Mazenod au vicaire général de Chambéry, 28 Oct. 1814', E. de Mazenod Lettres aux oblats de France, 181425 (Rome, 1982) i, p.4 ; M. Lyons Reading Culture and Writing Practice in Nineteenth Century France (Toronto, 2008) p.69
} 
Je suis obligé de te prévenir qu'il ne faut pas que tu comptes sur nous pour la mission de Marseille. Les missionnaires n'en ont pas la volonté et moi, je n'en ai pas le pouvoir. Je n'ai jamais eu le temps de rien écrire, de sort que je n'ai pas un seul sermon. ${ }^{913}$

Even if an experienced preacher was sufficiently comfortable in another language to preach, translating this material was not a straightforward matter. Preaching in a second language was thus a significant undertaking, and for this reason religious preachers preferred not to do so. It was for this reason that the Lutheran consistoire of Colmar sought to maintain a single priest for its French services, rather than splitting them between the four priests who worked in the parish. As the president of the consistoire wrote in 1856, 'personne n'ignore combien il est difficile, sinon impossible, de mener de front la prédication en deux langues. Un exercice fréquent peut seul amener la perfection relative, et dès lors elle n'est pas obtenue par quelques prédications seulement faites dans le cours de l'année' ${ }^{914}$ While a group of missionaries dedicated to preaching in Provençal might have facilitated missions within certain areas where religious practice in the language was welcomed, it also limited the range within which the missionaries could work. This difficulty became evident in 1823, when two members of the Missionaires de Provence joined a Jesuit mission to Gap, a diocese where religious preaching had traditionally taken place in French. According to Mazenod, the Jesuit superior in charge of the mission, 'ayant été prévenu que le p. Mye et le p. [Touche] ne seraient pas goûtés, étant accoutumés de prêcher en provençal, il ne les avait pas fait prêcher'. ${ }^{915}$ These two missionaries were instead tasked with instructing children in the catechism.

That Mazenod's efforts to propagate the faith through Provençal language preaching were considered exceptional points to a central conclusion; that religious groups were not the champions of minority and regional languages that later disputes between church and state might suggest. Rather, religious practice was a complex terrain over which language preferences and choices were made on in a rather ad hoc fashion, and reflecting various pressures. The habitual practices of the

\footnotetext{
913 'Mazenod à Forbin-Janson, 19 Dec. 1815', E. de Mazenod Lettres aux oblats i p.17

${ }^{914}$ AdHR $101 \mathrm{~J} 1406$ (fonds du consistoire de Colmar- diverses)

915 Mazenod au Sauzane, 29 Nov. 1823 in E. de Mazenod Lettres aux oblats de France, 1814-25 (Rome, 1982) i, p.137
} 
clergy of a diocese, as with the use of French in Gap, the pressure exerted by the state, and a desire to appeal more effectively to non French speakers all played a role in determining which language would be used in religious settings, and for which functions. Clergymen themselves emerged from an elite culture which denigrated the use of patois, even in religious contexts. The Jesuits, like Mazenod, in seeking to reach the masses had stood apart from this culture. Mazenod himself courted the disapproval of the Aixois nobility, who had expected the son of a prominent noble to occupy a important seat in the town, and were disappointed to find him preaching to the poor in Provençal. ${ }^{916}$ In short, the most striking feature of the language of organized religious practice during the period was not so much its influence on the sociolinguistic situation, but the way in which it reflected a broader nexus of practical and ideological concerns over linguistic diversity.

916 J. Leflon, Eugène de Mazenod, évêque de Marseille, fondateur des missionaires oblats de Marie immaculée, 1782-1861(Paris, 1957) 


\section{Conclusion}

The case of Mazenod and the Missionnaires de Provence brings the issue of continuity and change, and of the place of the Napoleonic episode in the sweep of French history to the fore. The legitimist Catholic preaching in Provençal would appear to presage the (perhaps hackneyed) characterizations of the entanglements between language, church and state during the latter half of the nineteenth century, particularly under the Third Republic. In this aspect Napoleon appears as the Jacobin on horseback. The period seems one of centralization, under a regime committed to what contemporaries understood as 'progress', in which attempts to impose officially sanctioned culturea national language and a state regulated church- sparked adhesion to altar, Bourbon crown and mother tongue. This impression is reinforced by the proliferation of salutations in regional languages to the returning Bourbons, composed by figures like the Provençal ultraroyalist Joseph Marius Diouloufet. ${ }^{917}$ To apply the formulation of Joseph Byrnes to the period, Mazenod would seem to prove Barère right; federalism, superstition, emigration and hatred of the Republic did indeed speak languages other than French. ${ }^{918}$

Such a neat alignment between the political history of France and that of its languages offers an appealing but in some respects misleading narrative. Recent studies of French regionalism have revealed a movement far more diverse than the traditional caricature of reactionary royalists and crypto-Catholics. ${ }^{919}$ Furthermore, the fall of Napoleon did little to alter the basic characteristics of the social context in which individuals used and judged language. This much is clear from Diouloufet's own royalist compositions. When the Duchesse d'Angoulême visited Provence in 1823 the festivities that accompanied her tour of the province were chronicled by Louis Robert, pro-

\footnotetext{
${ }^{917}$ R. Merle, 'Usage politique du provençal, 1814-1840', La question linguistique au Sud au moment de la Révolution Française : actes du colloque de Montpellier, 8-10 Novembre 1984 (Montpellier, 1985) vol.2 pp.4235

918 J. Byrnes, 'The Relationship of Religious Practice to Linguistic Culture : Language, Religion and Education in Alsace and the Roussillon, 1860-1890', Church History: Studies in Christianity and Culture vol.68 no.3 (1999) p.598

$919 \mathrm{~J}$. Wright, The Regionalist Movement in France : Jean-Charles Brun and French Political Thought (Oxford, 2003) pp.242-3
} 
Bourbon propagandist. Robert sought to demonstrate the loyalty of the inhabitants of Provence to the Bourbon throne by describing in detail the speeches and ceremonies that greeted the Duchesse on every leg of her tour. The majority of the elegies presented to the Duchesse- those of the prefect, the officers of the law courts, even the young student of the royal college in Marseille who recited a couplet in the Duchesse's honour- were all made in French. ${ }^{920}$ In Robert's account, the only Provençal text was a couplet by Diouloufet, performed to the Duchesse as she entered Aix by a group of the town's 'jeunes paysannes'. ${ }^{921}$ Dioufoulet's choice of performers reinforced the idea, clear throughout the correspondence gathered by the Coqueberts, that regional languages such as Provençal were the preserve of low status social actors- of rural dwellers and women. Speaking patois remained a way of adding local colour to a ceremony, of evoking tradition, in much the same way as the traditional dances performed for the Duchess by a group of women dressed as shepherdesses. ${ }^{922}$ The dynamic between appeals to social status, to the modern, and appeals to tradition evident under Napoleon remained.

The rhetoric of regional patrimony continued to suffuse discussions over linguistic practice into the Restoration period and July monarchy. In 1835 , the committee of the arrondissement of Cahors issued a decree banning the use of patois in the classrooms of the area. ${ }^{923}$ Teachers were no longer to use the patois themselves and were to encourage their students to speak only in French while at school. According to the committee, the move was necessary because the patois exercised a baneful influence on the French spoken by students, and, echoing the rhetoric of Napoleonic centralizers, because 'l'unité du politique et administrative du royaume réclame impérieusement I'unité du langage'. ${ }^{924}$ This impulse towards cultural homogenization was buttressed by a sense of the inadequacy of the patois itself. As the committee argued, 'les dialectes méridionaux, quelque

\footnotetext{
${ }^{920}$ L.J.M. Robert, L'hermite de Saint-Jean, ou Tableau des fêtes marseillaises lors de l'arrivée et durant le séjour de S.A.R. Madame, duchesse d'Angoulême, à Marseille no. 7 (1823) pp.5-7

${ }^{921}$ Ibid., no.8, pp.9-10

922 Ibid., no.5 p.8

${ }_{923}$ This measure, along with Charles Nodier's response is discussed in Gerson, Pride of Place pp.213-5

924 L'ami de la religion et du Roi vol.38, no.2386 (1835) p.460
} 
respectables qu'ils nous paroissent comme héritage de nos aïeux, n'ont pu s'élever au rang des langues écrites' ${ }^{925}$ In referring to patois as part of the 'héritage de nos aïeux' the committee positioned the local language as a feature of 'traditional' society, cherished but ultimately obstructing progress. Those opposed to the measures expressed themselves in very similar terms, stressing the role of language as an anchor for the community. Charles Nodier published a satirical pamphlet lampooning the committee for their measures against the 'langage naïf et doux qui nous venoit de nos mères, de nos nourrices, de nos premiers amis du village natal' ${ }^{926}$ This pattern of cultural politics, framed in terms of a tension between the unified nation and the particularity of place and heritage that was so evident during the Napoleonic period remained, even flourished, as the nineteenth century continued.

This dynamic was of equal relevance to the other somewhat hackneyed cliché about the Napoleonic period, that it unleashed a wave of national sentiment across Europe. The attempted francisation projects of the Napoleonic state did elicit intense dissatisfaction from amongst many speakers of other standardized languages. In the départements réunis, anti-Napoleonic sentiment was often prominently accompanied by a bitter hatred of the French language, and by a smouldering resentment of the linguistic demands of the French state. Two clear examples can be drawn from the Italian peninsula. John Chetwode Eustace held an unrelentingly negative opinion of French imperialism- the 1813 edition of his travels through Italy promised the reader 'occasional observations of the recent spoliations of the French'. Perhaps unsurprisingly, Chetwode Eustace found a visceral loathing to match his own in Piedmont, yet tellingly it was 'Frenchness' as a property of individual bodily practice- the language and manners of the 'French'- as much as their politics, that functioned as a locus for Piedmontese (and British) hatreds. As he wrote, 'the French, everywhere disliked, are here abhorred; [...] their language, manners, and persons are equally objects of antipathy; and [...] the day of deliverance and of vengeance is most ardently desired by

\footnotetext{
925 L'ami de la religion et du Roi vol.38, no.2386 (1835) p.460

${ }^{926} \mathrm{C}$. Nodier, Comment les patois furent détruits en France, conte fantastique (Paris, 1835) p.14
} 
the oppressed Piedmontese ${ }^{\prime}{ }^{927}$ Another traveller through Italy during the period, John Gustavus Lemaistre, recalled his disappointment at meeting Vittorio Alfieri, the Italian playwright and revolutionary, at the home of the latter's lover and host, the countess Albany, in Florence. ${ }^{928}$ In the last decades of the eighteenth century Alfieri had been a prominent Francophile, living in Paris and writing in French. Alfieri was initially supportive of the Revolution, but his disappointment with the Revolution as it descended into war and terror was intense. ${ }^{929}$ Lemaistre met Alfieri twice, but neither time was able to engage him in conversation. According to Lemaistre, Alfieri was 'disgusted with the crimes and excesses committed at Paris', and the playwright had 'become so decided an enemy to France, that he now refuses even to speak the language of that country'. ${ }^{930}$ Similar examples can be drawn from parts of present-day German annexed during the period. In her work on Hamburg, Kathryn Aaslestad cites the correspondence of Christoph Daniel Ebeling, a librarian and university professor in Hamburg, who greatly resented the cultural politics of the Empire; 'the loss of freedom was severely felt, our constitution abolished and [we] were subjected to a commission that was to Frenchify us in every respect. French superiors and rules, French laws, French language, and what was worst of all, French manners and principles' ${ }^{931}$

Linguistic practice, such commentary would seem to suggest, was politicized across Europe in a new way, or at least with a new intensity, by the events of the Revolutionary and Napoleonic period. Speaking French, once a marker of education and social status in the elite circles of the major cities of Europe, came first to connote support for the Revolution then allegiance to the Napoleonic regime. The new interest in a 'nationalized' style of linguistic practice, as an alternative to 'francisation', was expressed by Mme de Staël. In her account of exile in Germany and Austria

\footnotetext{
927 J. Chetwode Eustace, A Tour through Italy (London, 1813) i, p.413

928 C. Del Vento, 'La première fortune d'Alfieri en France : de la traduction française du « Panégyrique de Trajan par Pline » (1787) à la traduction des " oeuvres dramatiques » (1802)', Revue des études italiennes vol.50 no.1/2 (2004) p.220

${ }^{929} \mathrm{G}$. Luti, Letteratura e rivoluzioni : saggi su Alfieri, Foscolo, Leopardi (Firenze, 2002) pp.27-9

930 J.G. Lemaistre, Travels after the Peace of Amiens through Parts of France, Italy, Switzerland and Germany (London, 1806) i, p.339

931 Aaslestad, Place and Politics p.251; Originally printed in W. Coolidge Lane, 'Glimpses of European Conditions from the Ebeling Letters', Proceedings of the Massachusetts Historical Society vol.59 (1926) p.354
} 
during the period, de Staël wrote scathingly of foreigners who 'imitated' the French; 'un étranger francisé ne se permet pas une opinion ni une phrase qui ne soit orthodoxe et le plus souvent c'est une vieille orthodoxie qu'il prend pour l'opinion du jour'. ${ }^{932}$ De Staël argued that the stale and derivative ideas of those who imitated French mores and adopted the French language arose from an unwillingness to embrace the genius and inspiration of the native, national tongue. As she commented of those she encountered in the Austrian capital, 'on croit trop à Vienne qu'il est de bon goût de ne parler que français; tandis que la gloire et même l'agrément de chaque pays consistent toujours dans le caractère et l'esprit national'. ${ }^{933}$

However, as with the rhetoric of tradition employed by speakers of France's regional languages, the assertion of a national style of communication suited to the expression of selfhood was only one of the strategies elites chose in response to French domination, and there are equally compelling examples of local elites pursuing strategies of linguistic assimilation. Perhaps the best example of such assimilation, according to Michael Broers, was Napoleon's librarian, Carlo Denina..$^{934}$ In an 1803 pamphlet entitled 'dell'uso della lingue francese', printed in the form of a letter addressed to Carlo Arnaud, professor of rhetoric and philosophy on the French language, Denina acknowledged that French rule, and the linguistic policies that accompanied them, would lead to the displacement of Italian by French: 'Io non dubiot [...] che la riunione del Piemonte alle Francia, e l'ordine venuto in sequito di usare negli atti publicca la lingue francese in vece dell'italiana, debba anche cangiar tosto o tardi la lingua letteraria del paese' ${ }^{935}$ However, as Ferdinand Brunot observes, Denina considered this a positive development. He argued that the Piedmontese would benefit from the superior French language, which was at any rate more widely spoken in France and Europe, and that since Piedmontese, like French and Tuscan Italian, was a corrupted form of Latin, and thus an 'Italian dialect' in its own right, the introduction of French would simply replace one imposition from

\footnotetext{
932 Mme de Staël, De l'Allemagne (Paris, 1968) p.97

933 Ibid., p.94

934 Broers, The Napoleonic Empire in Italy pp.214-5

${ }^{935}$ C. Denina, 'Dell'uso della lingua francese', C. Denina, C. Marazzini (ed.) Storia delle lingue e polemiche linguistiche (Piacenza, 1985) p.70
} 
the outside with another, more useful, one. ${ }^{936} \mathrm{~A}$ similar indifference, if perhaps not such outright hostility, towards linguistic nationalism was evident in the preservation of the French language Napoleonic legal codes in the Rhineland after the Fall of Napoleon. An unofficial German translation only appeared in 1836, and the French language official versions were not supplanted by what was effectively an official German version preserving most of the features of the French code until $1851 .{ }^{937}$

Figures such as Denina were responding to the Napoleonic regime's linguistic demands. While the ultimate ambition of spreading French to the territory of the Empire was never abandoned, the exigencies of political management encouraged a more gradualist approach over time. The earlier annexations of territory directly to the French state- those of Belgium, the Rhineland, Piedmont, the Ligurian Republic and the states of Parma and Piacenza- had always involved the imposition of French as the official language, particularly in legal contexts. ${ }^{938}$ However, following the annexation of Tuscany in December 1807, this policy was adjusted. Italian was permitted alongside French as an official language, in recognition of the special beauty of the Tuscan dialect and its significance as the source of the Italian language:

les peuples de nos départemens de la Toscane sont, de tous les peuples de l'ancienne Italie, ceux qui parlent le dialecte italien le plus parfait, et qu'il importe à la gloire de notre Empire et à celle des lettres que cette langue élégante et féconde se transmette dans toute sa pureté. ${ }^{939}$

This act even made the safeguarding of Tuscan linguistic patrimony the responsibility of the Napoleonic state, with the establishment of an annual prize fund of 500 Napoleons, taken from the

\footnotetext{
${ }^{936}$ Brunot HLF vol.XI pt.2 p.15 ; Denina 'Dell'uso della lingua francese' p.72: 'Il nostro linguaggio piemontese è uno de' dialetti d'Italia, non già un italiano o sia toscano corrotto, ma bensí un latino corrotto'.

937 J. Engelbrecht, 'The French Model and German Society: The Impact of the Code Penal on the Rhineland', X. Rousseau, M.-S. Dupont-Bouchat and C. Vael (eds.), Révolutions et justice pénale en Europe: Modèles français et traditions nationales, 1780-1830 (Paris, 1999) pp.106-7

${ }^{938}$ See above, ch. 6

${ }^{939}$ Bulletin des lois no.222 p.147
} 
civil list, to be distributed 'aux auteurs dont les ouvrages contribueront le plus efficacement à maintenir la langue italienne dans toute sa pureté'. ${ }^{940}$

The policy elaborated during other late annexations similarly took a less belligerent approach to linguistic diversity. In the Netherlands, annexed in 1810, Dutch was permitted alongside French in official legal documentation. In the Illyrian provinces, annexed in 1809 , legal documents could be drafted in German and Italian as well as French, while the governor general was also convinced to support the establishment of an 'Illyrian Academy' in Dubrovnik. As he wrote to the minister of the interior, 'le gouvernement est peut-être plus intéressé à propager la langue française, cependant un tel établissement peut avoir ses avantages'. ${ }^{941}$ In this instance, producing the accoutrements of a standardized language would aid French rule; 'une grammaire Illyrique et française serait fort utile [...] je me suis déjà occupé des moyens d'en avoir une' ${ }^{9}{ }^{922}$ Joseph-Marie Degérando, the Intendant charged with the abortive annexation of Catalonia, recommended the use of Catalan for the publication of the Code Napoleon as a means of securing support from Catalans who resented Spanish linguistic oppression. This proposal failed to find much favour within a legal profession educated in Castilian and wedded to the language as a marker of status within the judicial system, and the tepid attempts at promoting Catalan during the period, most of which emerged from a single nationalist jurist named Tomàs Puig, who envisioned an improbable federalist settlement for Catalonia under French direction, seem to have inspired greater bemusement than passionate adhesion. ${ }^{943}$

\footnotetext{
${ }^{940}$ Bulletin des lois no.222 p.148

${ }^{941}$ An F17 16141 (Organisation de l'instruction publique dans les pays conquis- Provinces Illyriens, Catalogne, Alpes Maritimes) Extrait d'une lettre du Gouverneur Général des provinces illyriens au Ministre de l'intérieur, 13 Dec. 1811

${ }^{942}$ An F17 16141 Extrait d'une lettre du Gouverneur Général des provinces illyriens au Ministre de l'intérieur, 13 Dec. 1811

${ }^{943}$ M. Broers, 'La mission de Joseph-Marie Degérando en Haute-Catalogne en 1812 : La loi universelle de l'empire et la dernière réunion', Napoléon, Bayonne et l'Espagne : Actes du colloque organisé par la société des sciences, lettres et arts à l'occasion du bicentenaire de l'entrevue de Bayonne (Paris, 2011) pp.245-7 ; S. Jacobson, Catalonia's Advocates : Lawyers, Society and Politics in Barcelona, 1759-1900 (Chapel Hill, 2009) pp.82-3, 168
} 
This more lax approach did not presage the abandonment of francisation as the ultimate goal of the regime. While the terms of the annexations of the Netherlands permitted the use of Dutch, they also required the establishment of French language teachers at all schools, primary and secondary. ${ }^{944}$ In the Illyrian Provinces, the Governor General continued to understand spreading French as an objective of French governance despite the authorisation of Italian and German as legal languages and his recommendation to establish an Illyrian academy. As he wrote in a report on the education system in the region, 'on veillera à ce qu'on enseigne autant qu'on le pourra les premiers éléments de la langue française'. ${ }^{945}$ When local officials pointed to the value of languages other than French as an element of linguistic patrimony, as a medium for the expression of selfhood or as an almost intractable feature of local society, those at the centre saw a practical reality that might not be bent easily to their will. This meant, as in the law courts and the schools of the Empire, tolerating the use of languages other than French to ensure these institutions continued to function. Beyond this, men like Degerando were willing to exploit the rhetoric of linguistic nationalism to pose as liberators. Even if linguistic unification remained the ultimate goal, the regime learned mother tongue politics.

Unifying the language of what was a linguistically diverse population was clearly a priority for the Napoleonic regime, and this did distinguish it from the restored Bourbon government that followed the fall of the Empire. While social change remained an objective for paternalistic reformers like Christophe de Villeneuve, the royalist prefect of the Bouches du Rhône who began his administrative career under Napoleon, linguistic homogenization was pursued with less urgency at the centre, whether as a result of changing ideological predilections in Paris or the vast reduction in the number of 'foreign' language speakers. ${ }^{946}$ Either way, measures from Paris regulating linguistic practice largely dried up, and when they did appear reflected a greater degree of linguistic tolerance,

\footnotetext{
${ }^{944}$ Bulletin des lois (1810) no.336 ; In practice, primary school teachers unable to provide tuition in French were granted temporary leave to practice- see above, chapter 4.

${ }^{945}$ An F17 16141 Rapport du Gouverneur Général des provinces illyriens au Ministre de l'intérieur, 28 Nov. 1811

${ }^{946}$ McPhee, Rural Life p.40
} 
such as the 1824 act establishing German tuition at the Royal Forestry School in Nancy ${ }^{947}$ This thesis therefore adds to the burgeoning literature that views the period as one characterised by statebuilding projects. Even as the democratic gains of the Revolutionary period were reversed, displaced by a political authoritarianism, the Napoleonic state was self-consciously engaged in the consolidation of a 'new regime', to appropriate Isser Woloch's phrase, and the new reach of state centralization into features of everyday life called basic features of social practice- the language of teaching, preaching and pleading- into question. ${ }^{948}$ For the Napoleonic administrator, state building, the unification of the diverse territories of the Empire and the integration of its culturally diverse populations was a mission, and the attempts to spread French during the period underscore this impulse as clearly as any other. It is difficult to deny that, based on the regime's approach to language, something like the cultural imperialism identified by Michael Broers featured among the objectives of Napoleonic governance. ${ }^{949}$

However, terms such as 'linguistic imperialism' can imply a rigidity that would be misleading in relation to the Napoleonic period. The later annexations carried out by the Napoleonic state reveal a degree of flexibility over competing priorities, as did the appointment of bilingual judges and the toleration of preaching in languages other than French. The ultimate ambition of spreading French remained, manifest in seminary regulations and efforts to francise schoolrooms, but was constrained by the fear of bringing institutions to a halt. Moreover, the thesis has also demonstrated the important role of the men who staffed these institutions in the elaboration of linguistic practice. Not only did these Napoleonic functionaries ultimately determine the language in which these institutions worked, they often articulated arguments in favour of greater latitude when it came to the linguistic demands of Paris. As the example of Degerando in Catalonia and the Napoleonic state's pledge to give succour to Italian literature in Tuscany show, these ideas could flow up as well as

\footnotetext{
947 Bulletin des lois (1824) ser.8 no.8

948 Woloch, The New Regime pp.429-30

${ }^{949}$ Broers, The Napoleonic Empire in Italy p. 3
} 
down. This thesis has also shown that the process should not be understood as unidirectional, as the imposition from centre onto periphery.

These functionaries relied on their place within bureaucratic hierarchies to secure their status. Where they articulated opposition or sought to moderate centralizing efforts their concern often centred on the safeguarding the value of knowledge and expertise as much as national sentiment. The Castilian speaking lawyers of Catalonia, for example, sought to protect the status of a language they had expended effort to master. Similarly, when the schoolteachers and clergymen of the eastern parts of the Alpes Maritimes proved reluctant to embrace French instead of Italian this was not a defence of a subaltern regional culture. After all, when people gathered in the area to celebrate the fall of Napoleon and the return of the house of Savoy they sung not in Italian, but in 'dialecte niçoise'. ${ }^{950}$ The language of Dante and Petrarch was the language of literate, elite linguistic practice, and these figures acted primarily to safeguard their distinction and expertise.

The relationship between the local notability and the state was clearly different where there existed an ' $\mathrm{H}$ ' variety in its own right. Local dialects offered problems of communication in certain contexts, for example in the law court where informal processes of translation became necessary. These difficulties could be leveraged by notables, as by the members of the Napoleonic law courts, or local administrators, to underscore their vital role as intermediaries. Where notables had previously employed a different standardized variety their expertise suddenly became more problematic. In this context, knowledge of French, the authorized variety of the centralizing bureaucracy, became more valuable to local notables seeking office. However, the weight of previous linguistic practice often presented difficulties for Napoleonic administrators confronted by a society that wrote in a different language. Local notables themselves found their existing knowledge devalued and were obliged either to embark on a tricky path of assimilation or resist the linguistic demands of the centre. The Empire, as the evidence from the Coqueberts' enquiry and the 
folklorists of the nineteenth century who charted the practice of code-switching in popular singing, was composed of three main zones. The lle de France and parts of northern France where French or very closely related dialects were spoken, the Romance speaking areas of present day France, Switzerland, Belgium and Northern Italy where French functioned as an ' $\mathrm{H}$ ' variety, and those areas where another standardized language was spoken. This distinction was crucial, because as the evidence from the law courts, church and education system shows, Napoleonic language policy tended to be a far greater obstacle in the latter areas than where French already dominated written culture.

Many of these tensions were manifested in the Napoleonic state's attempts to describe society. These efforts, particularly the departmental statistics begun under the directory and pursued during the Napoleonic period, revealed the ideological character of the Napoleonic regime. Describing society was the first step in remaking it, a notion driven by Enlightenment notions of social progress. Yet as the work of the Coqueberts on language revealed, the centralizing impulse of the regime stimulated reflection on the value and place of local knowledge. Local notables articulated the value of regional culture as patrimony, and emphasised their significance as experts on local knowledge forms. Nowhere was this clearer than in the effusion of interest generated by the Coqueberts' enquiries or the defence of native legal officials and informal translation practices by members of the judiciary.

While the relative prestige of different languages altered the position of the local notability in relation to the centre, the process of negotiating between local forms of knowledge and identification and the forms authorised by the centre characterized the Napoleonic period in a general way. The various iterations of this dynamic between centre and periphery, the responses of figures like Ebeling, Alfieri or Nodier may have expressed a similar countervailing aesthetic of authentic communication, militating against the demands of the centre. Yet it was those who stood in the courtroom, the classroom, who spoke from the pulpit or the bench, who navigated these 
conflicting demands and who ultimately determined in which language the French state spoke, to whom, and in what context. 
Appendices

Figure 1: Language in the Statistiques départementales (an VII- 1813)

Page 292

Figure 2 : No. of Statistiques départementales Containing information on Language by Year

Figure 3 : No. of Statistiques départementales Without information on Language by Year

Page 293

Figure 4: Translators of the Parable by Occupation

Page 294

Figure 5: Eugène Coquebert de Montbret's Typology of Languages of the French Empire

Page 295

Figure 6: Linguistic Geography of the Napoleonic Empire

Page 296

Figure 7: Geographic Distribution of Translations of the Parable in the Dialects of the Napoleonic Empire, 1806-1812

Page 297

Figure 8: Bilingual Versions of Bergère-Monsieur Dialogues

Page 298

Figure 9: Alpes Maritimes- Communes by Language of Instruction, year XI (1803)

Page 299

Figure 10: Alpes Maritimes- the French-Italian Linguistic Border, 1806

Page 300

Figure 11: County of Nice, Communes by Language of Instruction, 1850

Page 301

Figure 12: Use of French as an Official Language in the Departments of the Empire after decrees published in the Bulletin des Lois

Page 302

Figure 13: Informal Diglossia in the Legal System in Spoken Contexts in the Observations des tribunaux sur le projet du code criminel de l'an IX

Page 303

Figure 14: Judges in the resort of the court of appeal of Genoa by origin

Page 304

Figure 15: Judges in the jurisdiction of the court of appeal of Trier by origin

Page 304

Figure 16: Francophone judges in the jurisdiction of the appeal court of Genoa by origin

Page 305

Figure 17: Francophone judges in the jurisdiction of the appeal court of Trier by origin

Page 305

Figure 18: Distribution of Politically Seditious Priests by Department, 1804

Page 306 
Figure 1: Language in the Statistiques départementales (an VII- 1813)

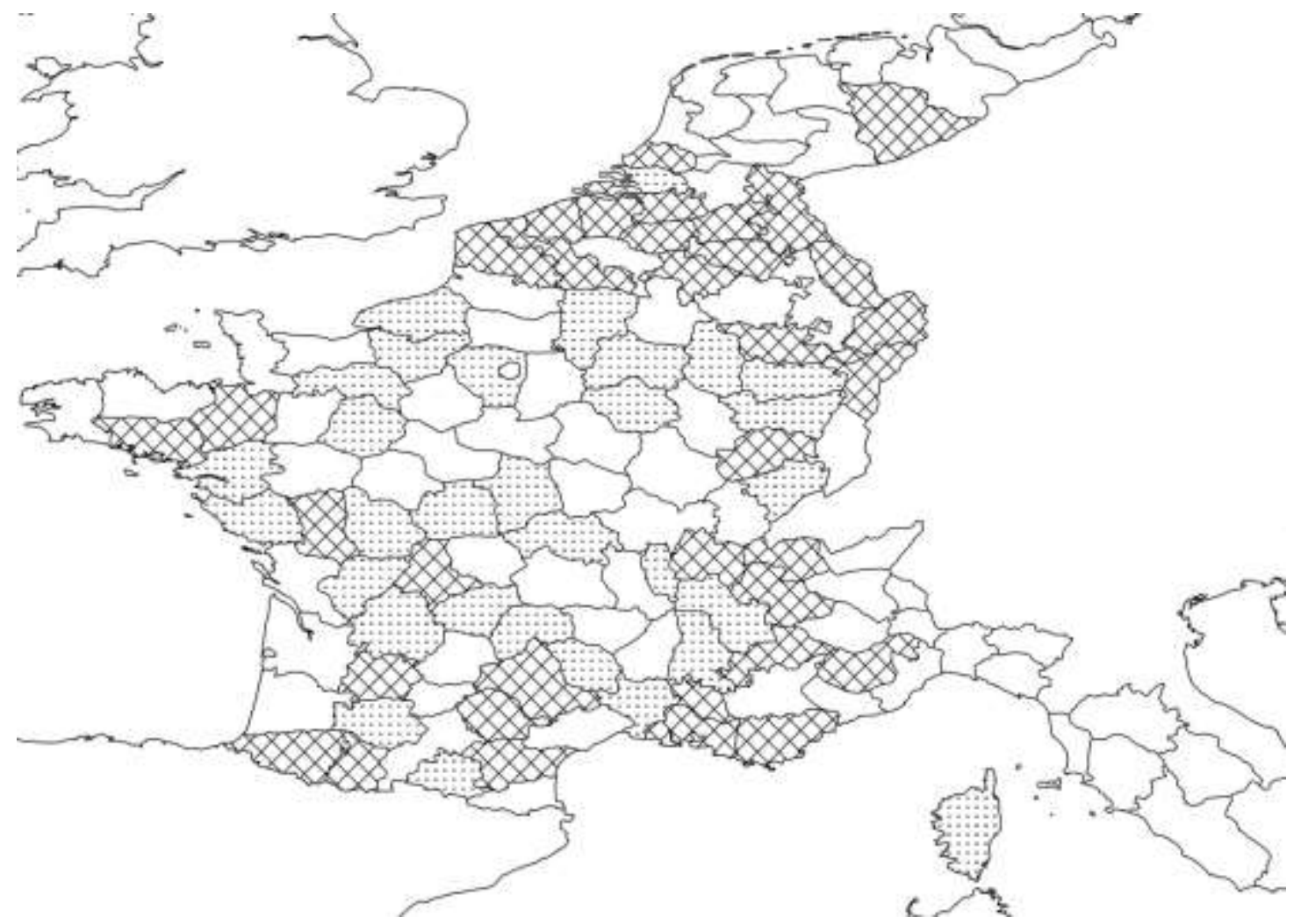

Statistiques départementales containing information on language

$\square$ no
$\square$ no data
$\square \times$ yes


Figure 2 : No. of Statistiques départementales containing information on Language by Year

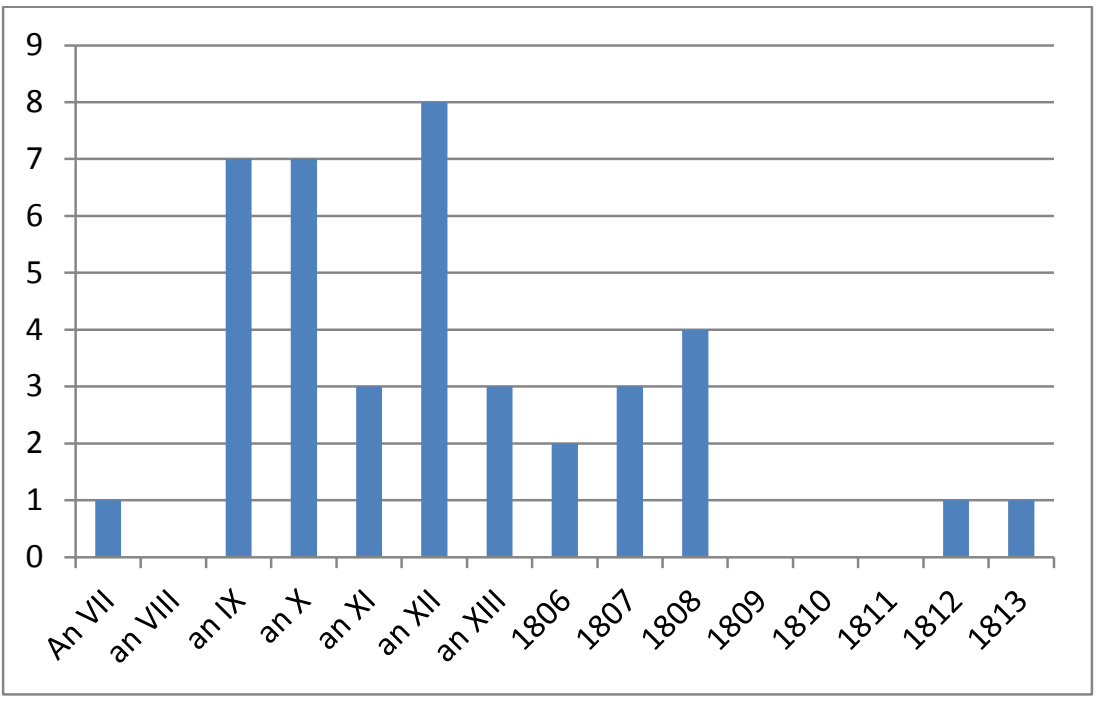

Figure 3 : No. of Statistiques départementales without information on Language by Year

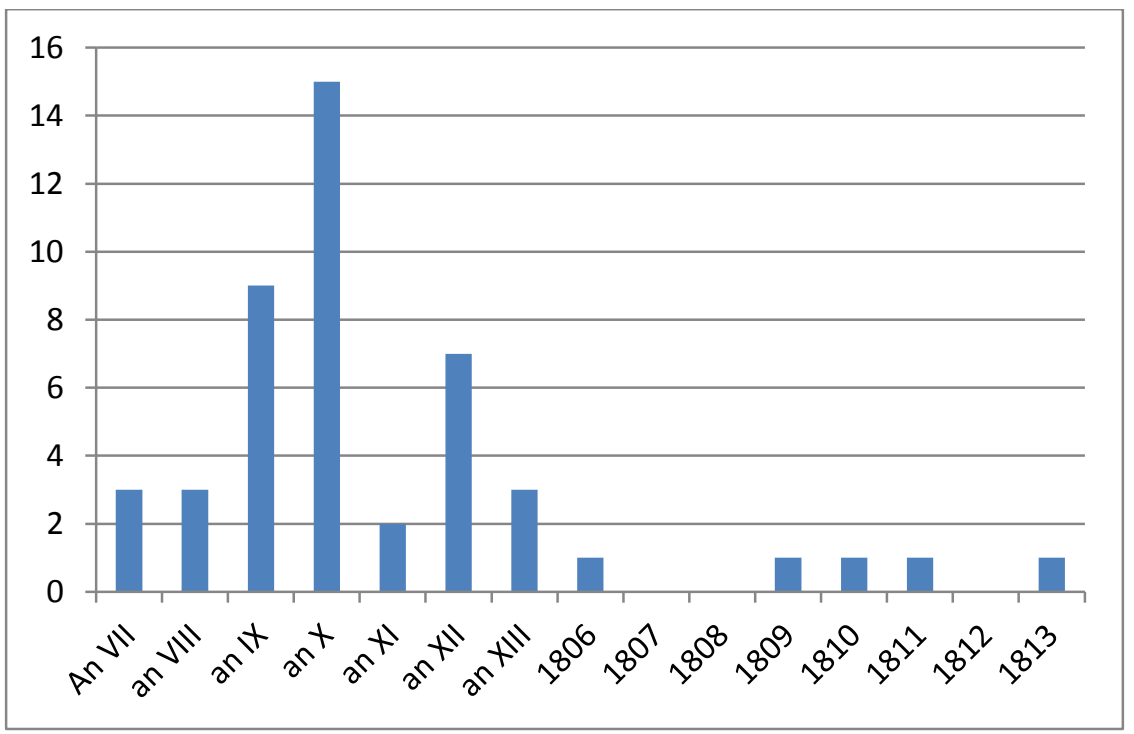


Figure 4: Translators of the Parable by Occupation

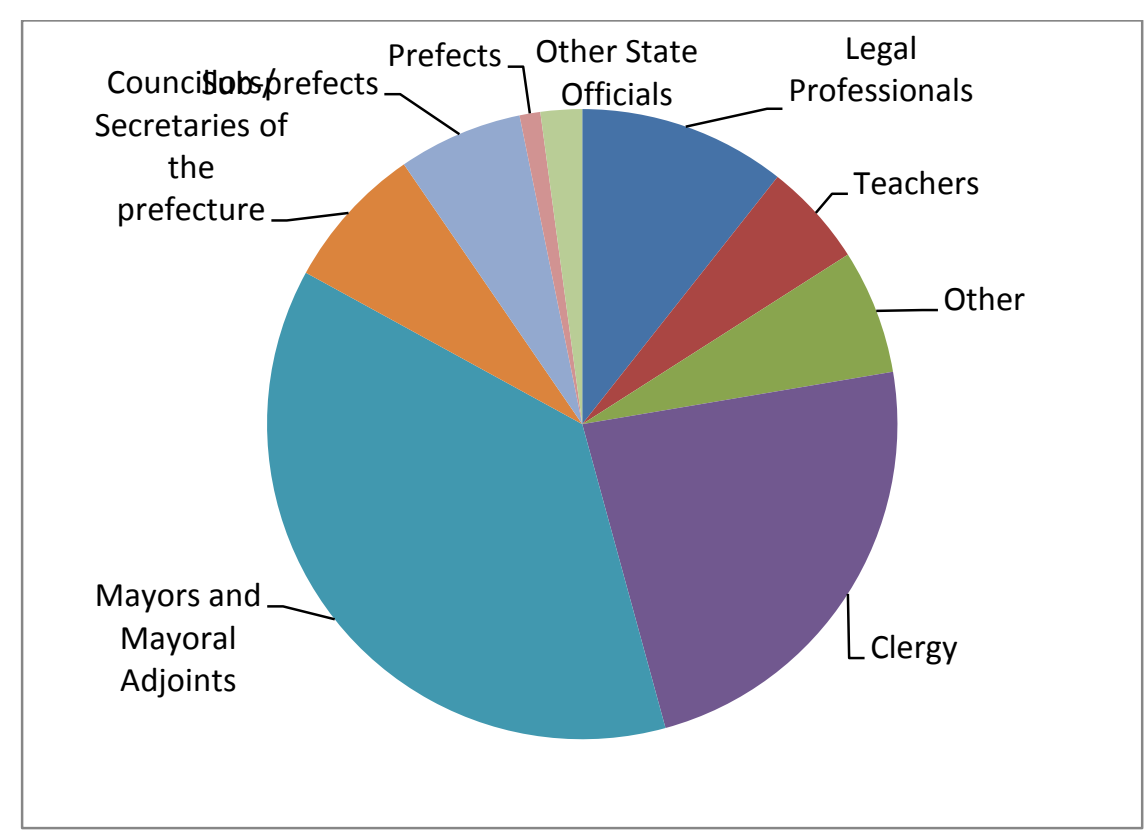


Figure 5: Eugène Coquebert de Montbret's Typology of Languages of the French Empire

\begin{tabular}{|c|c|c|c|}
\hline \multirow{33}{*}{$\begin{array}{l}\text { Indigenous } \\
\text { Languages }\end{array}$} & \multirow{22}{*}{$\begin{array}{l}\text { Les Idiomes dérivés } \\
\text { du latin }\end{array}$} & \multirow{9}{*}{$\begin{array}{l}\text { Langue D ‘Oïl- La langue } \\
\text { française proprement dite }\end{array}$} & Le Wallon \\
\hline & & & Le Picard \\
\hline & & & Le Lorrain \\
\hline & & & Le Franc Comtois \\
\hline & & & Le Savoyard \\
\hline & & & Le Lyonnais \\
\hline & & & Le Bourguignon \\
\hline & & & Le Poitevin \\
\hline & & & Le Saintongeois \\
\hline & & \multirow{8}{*}{$\begin{array}{l}\text { Langue d'Oc- L'idiome du } \\
\text { midi de la France }\end{array}$} & Le Provençal \\
\hline & & & Le Dauphinois \\
\hline & & & Le Languedocien \\
\hline & & & Le Limousin \\
\hline & & & Le Périgourdin \\
\hline & & & L'Auvergnat \\
\hline & & & Le Catalan \\
\hline & & & Le Gascon* \\
\hline & & \multirow[t]{5}{*}{ L'Italien } & Le Piémontais \\
\hline & & & Le Gênois \\
\hline & & & Le Plaisantin \\
\hline & & & Le Toscan \\
\hline & & & Le Roman \\
\hline & \multirow{6}{*}{$\begin{array}{l}\text { Les Idiomes } \\
\text { germaniques }\end{array}$} & \multicolumn{2}{|l|}{ L'Alsacien } \\
\hline & & \multicolumn{2}{|l|}{ L'Allemand des Bords du Rhin } \\
\hline & & \multicolumn{2}{|l|}{ Le Flamand et le Hollandais } \\
\hline & & \multicolumn{2}{|l|}{ Le Frison } \\
\hline & & \multicolumn{2}{|l|}{ Le plat Allemand } \\
\hline & & \multicolumn{2}{|l|}{ L'Allemand de suisse } \\
\hline & \multirow[t]{4}{*}{ Breton } & \multicolumn{2}{|l|}{ Dialecte de Léon } \\
\hline & & \multicolumn{2}{|c|}{ Dialecte de Cornouaille ou Quimper } \\
\hline & & \multicolumn{2}{|l|}{ Dialecte de Tréguier } \\
\hline & & \multicolumn{2}{|l|}{ Dialecte de Vannes } \\
\hline & \multicolumn{3}{|l|}{ Basque } \\
\hline \multirow{2}{*}{$\begin{array}{l}\text { Diaspora } \\
\text { Languages }\end{array}$} & \multicolumn{3}{|c|}{ Le 'Jargon allemand des Juifs' } \\
\hline & \multicolumn{3}{|l|}{ La langue des Gitans } \\
\hline
\end{tabular}

* Gascon was categorized as a separate language in its own right by Eugéne in his 1812 report, but Charles-Etienne placed it alongside the other 'Langues $d^{\prime} O c^{\prime}$ '. 
Figure 6: Linguistic Geograpy of the Napoleonic Empire

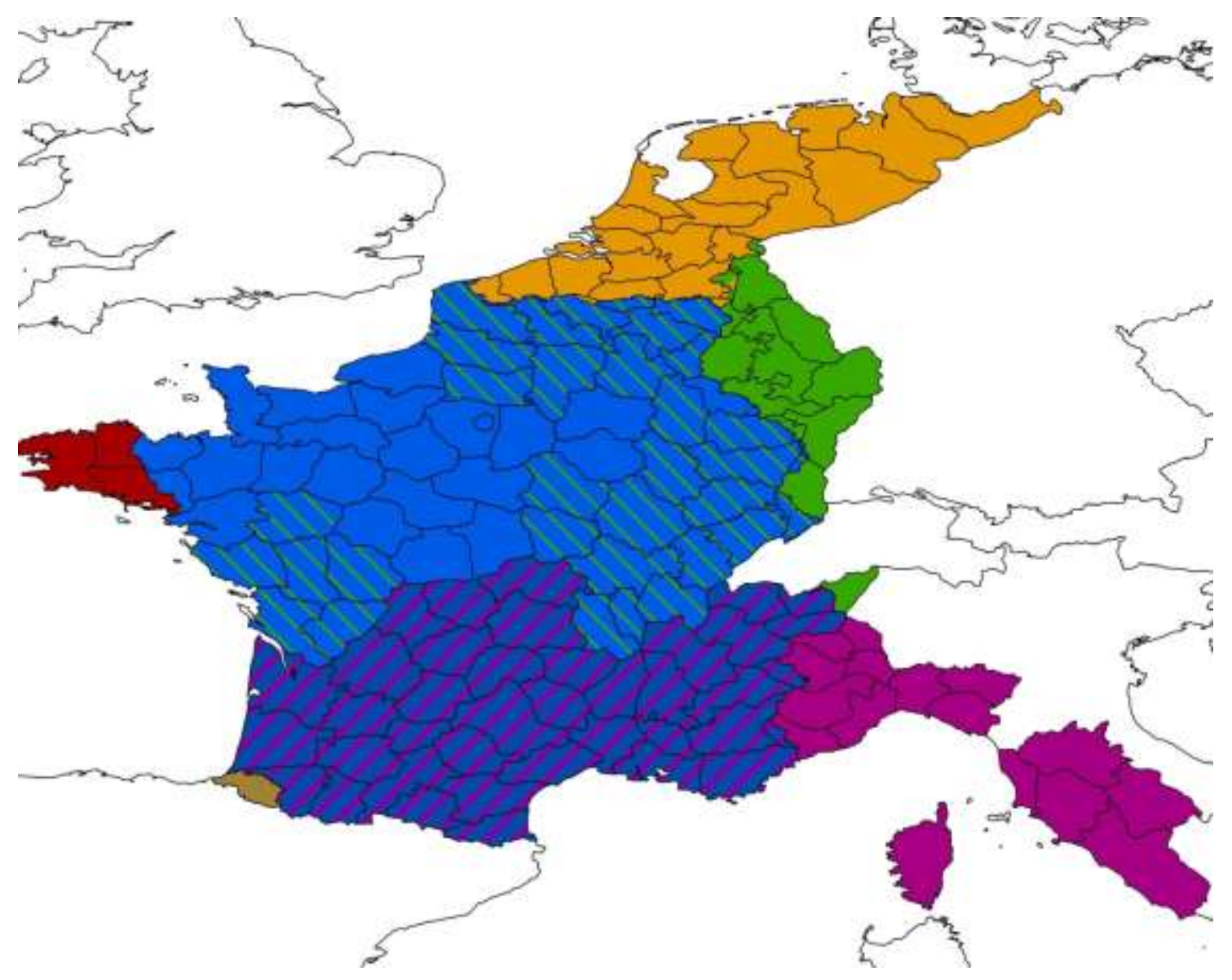

Languages:
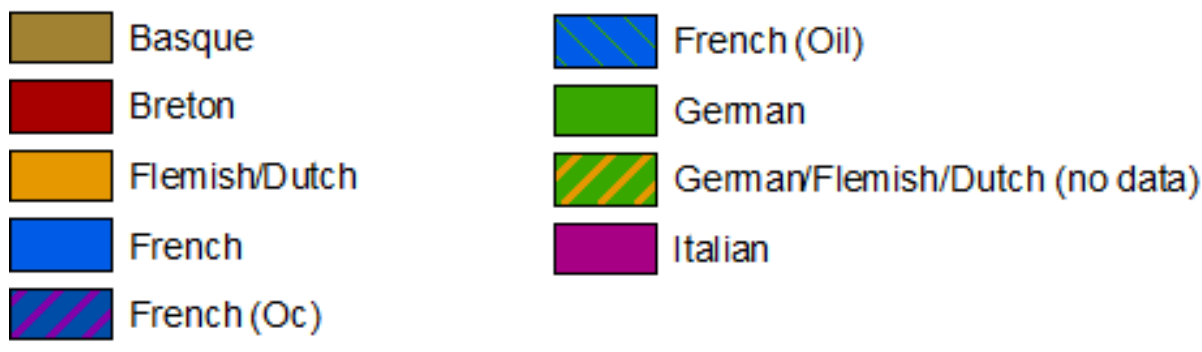
Figure 7: Geographic Distribution of Translations of the Parable in the Dialects of the Napoleonic Empire, 1806-1812

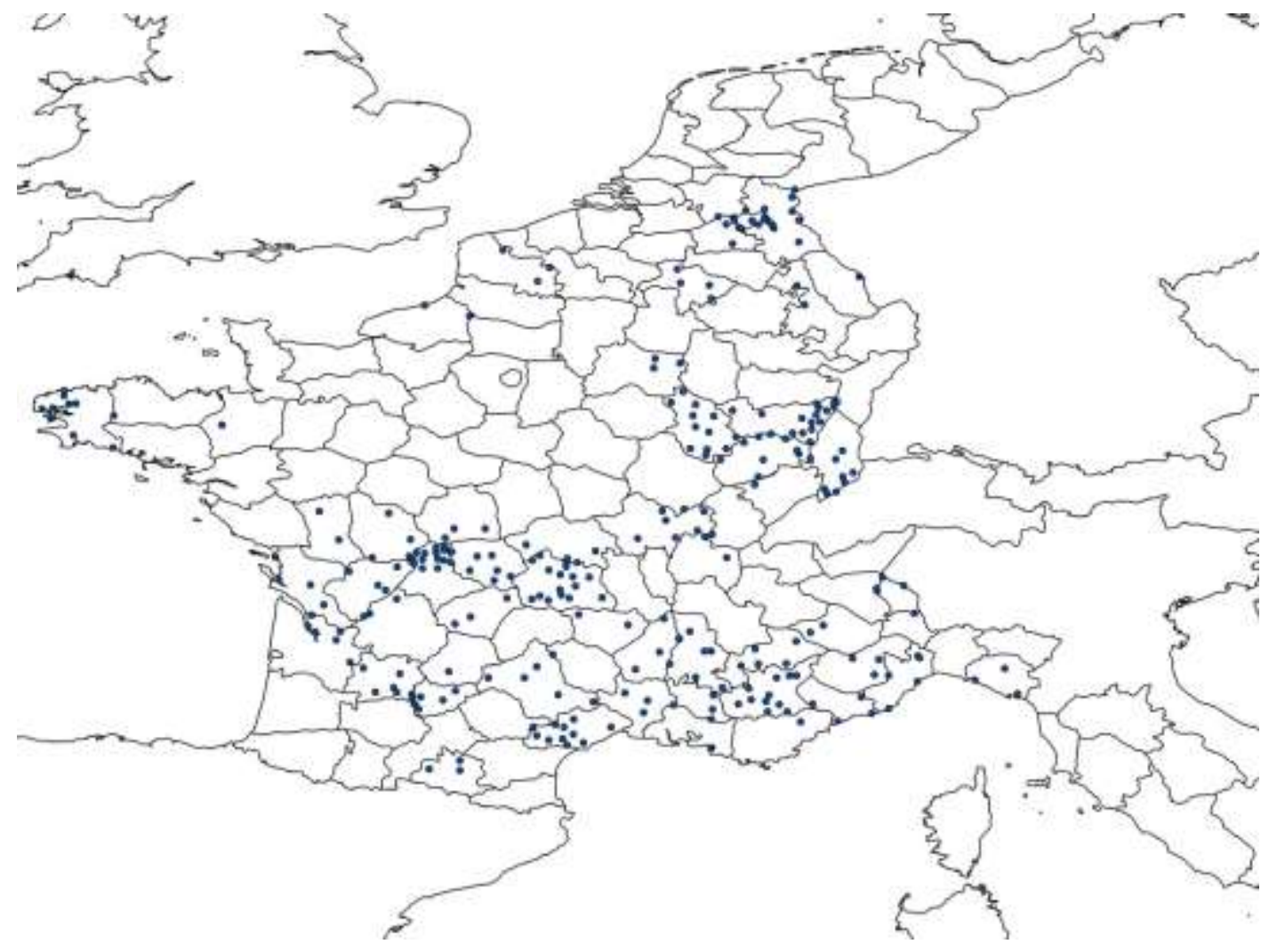

- Location of Translation of the Parable of the Prodigal Child 
Figure 8: Bilingual Versions of Bergère-Monsieur Dialogues

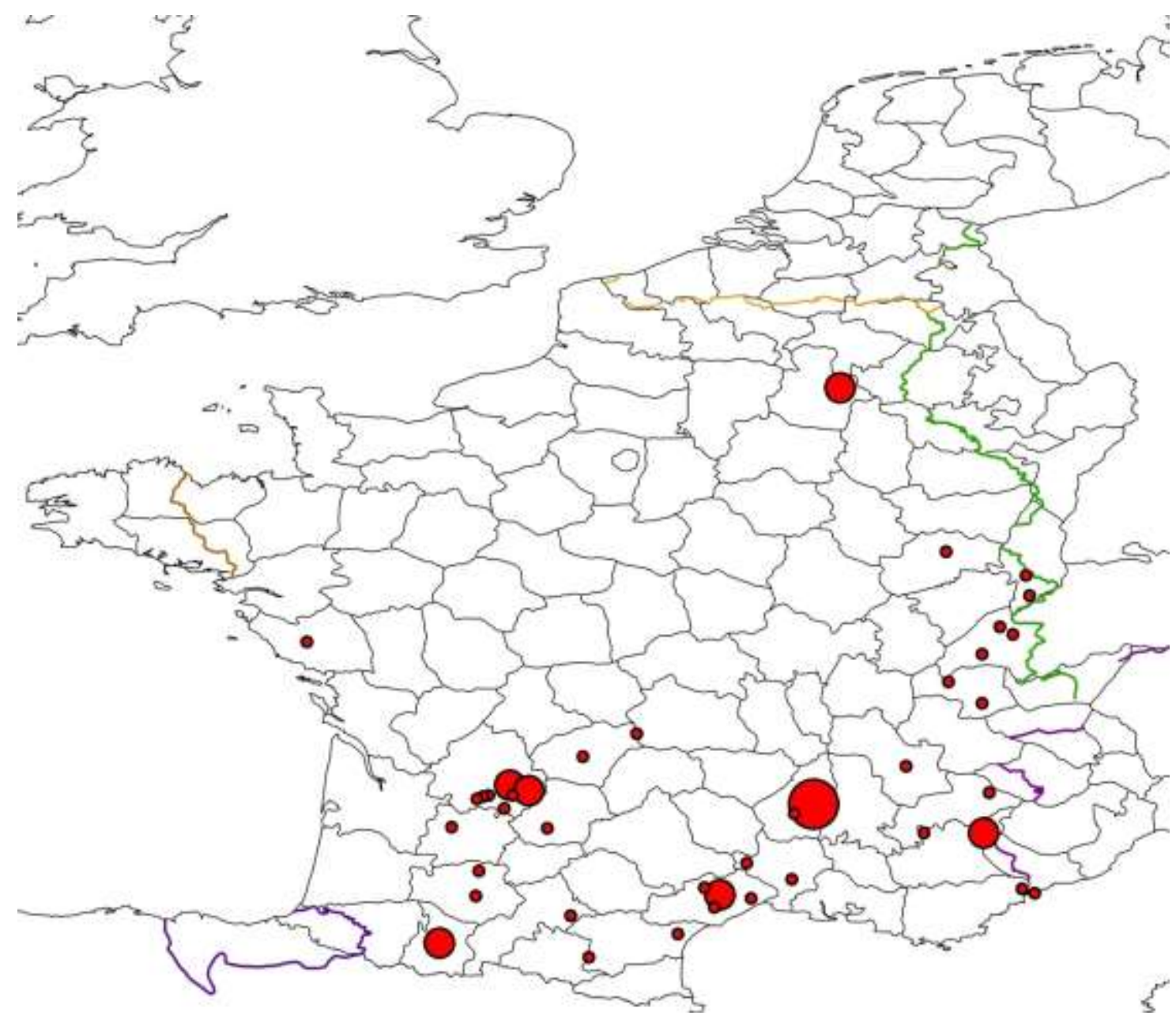

No. of Bilingual Bergère-Monsieur Dialogues Collected
- 1
2
3

Boundaries of the Languages of the French Empire- 1806

- Basque - German
Italian
Flemish


Figure 9: Alpes Maritimes- Communes by Language of Instruction, year XI (1803)

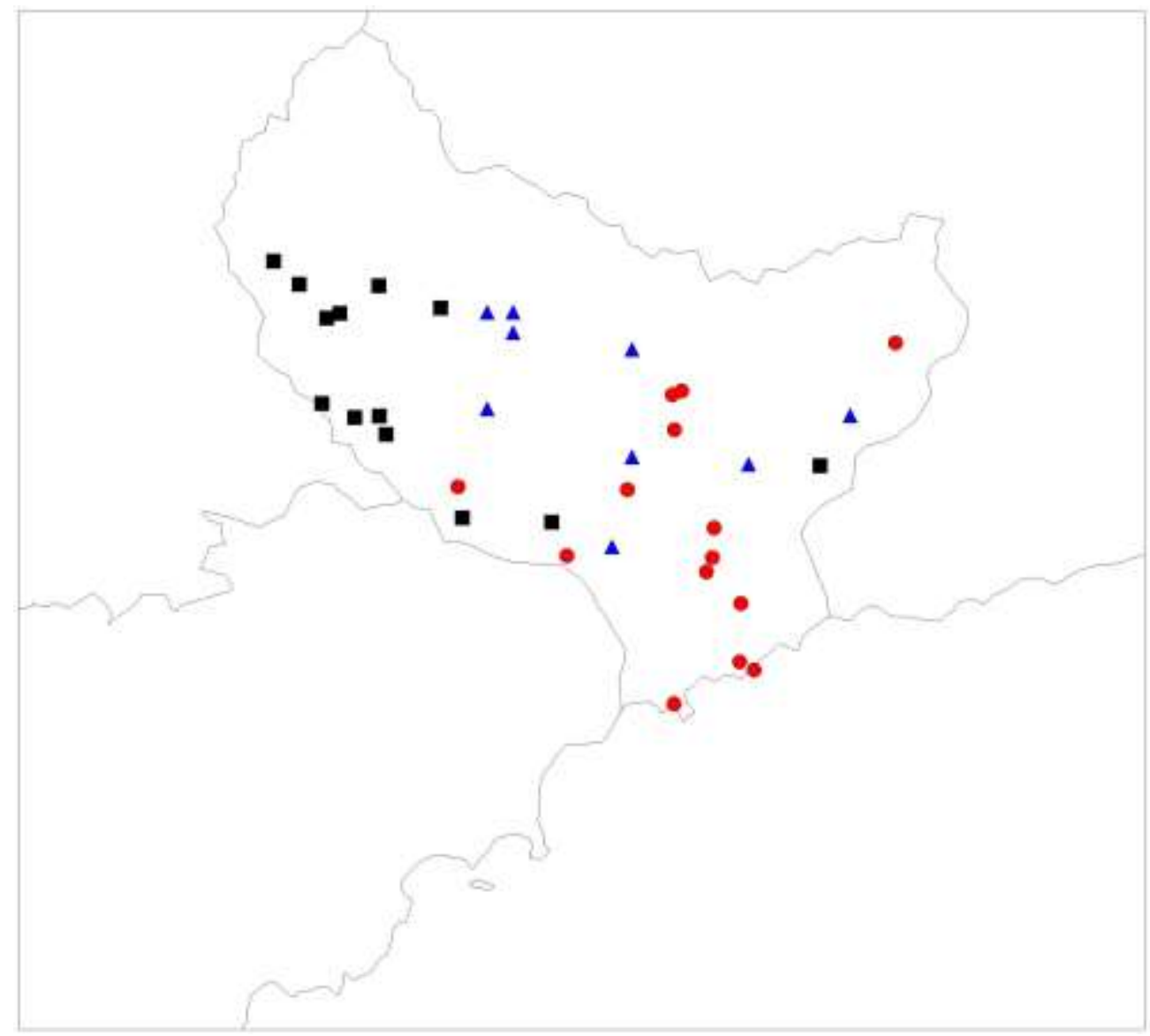

Key

Communes with French-only education

$\triangle$ Communes with Italian-only education

Communes with both French and Italian language education 
Figure 10: Alpes Maritimes- the French-Italian Linguistic Border, 1806

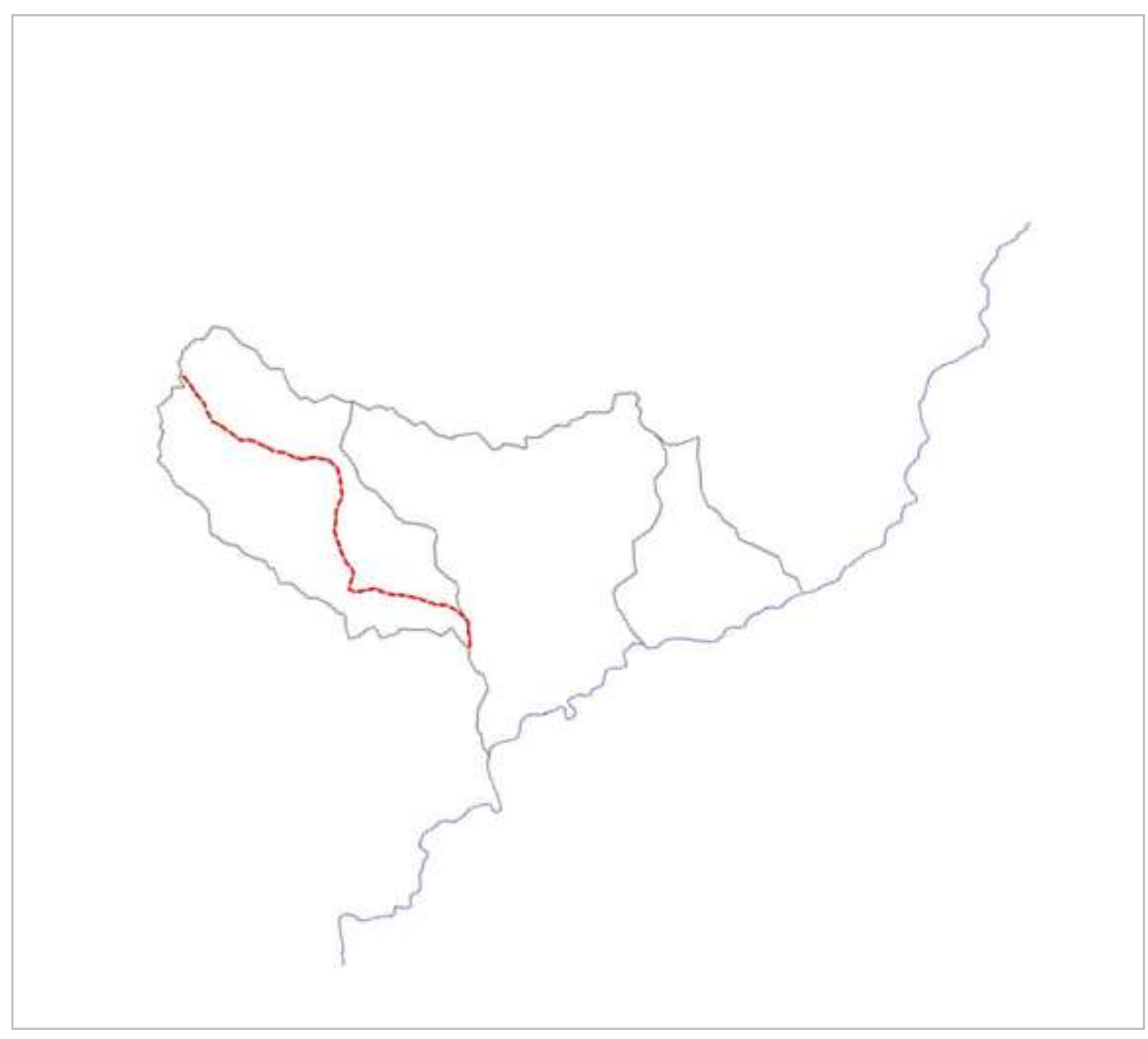

Key

- - - Linguistic border between French and Italian 
Figure 11: County of Nice, Communes by Language of Instruction, 1850

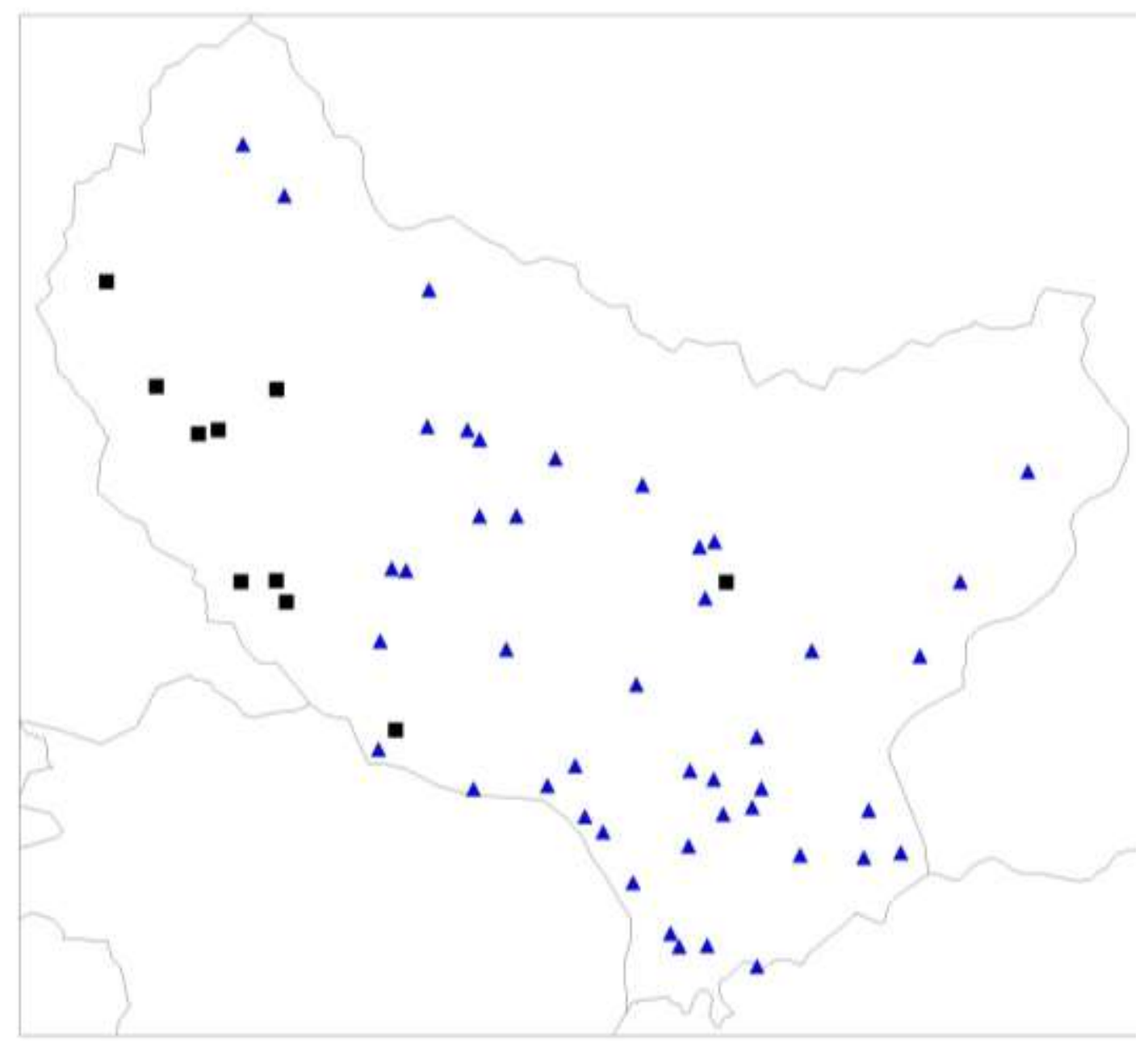

Key

Communes with French-only education

$\triangle$ Communes with Italian-only education 
Figure 12: Use of French as an Official Language in the Departments of the Empire after decrees published in the Bulletin des Lois

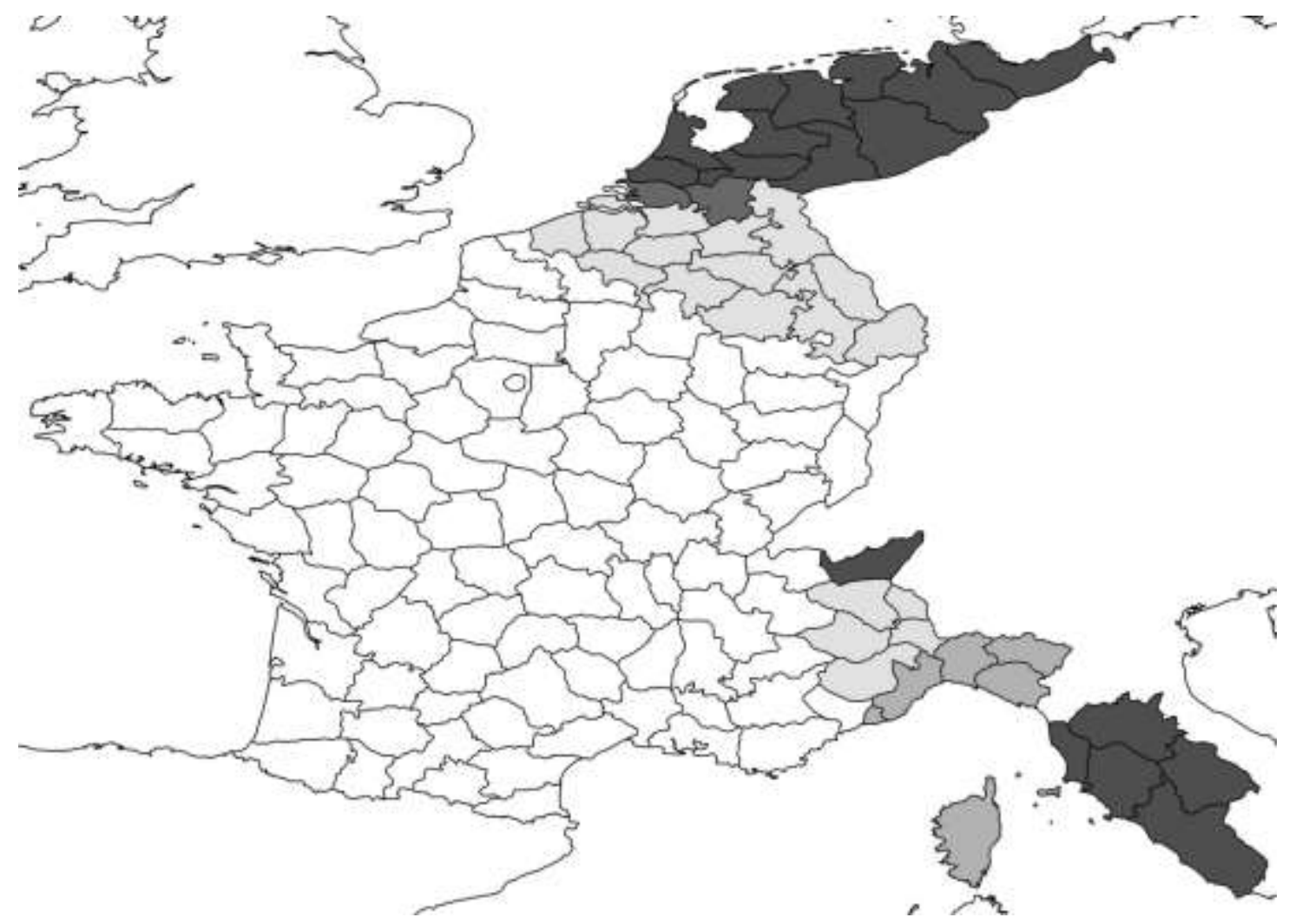

Date from which French established as official language

June 1804

January 1809

Unspecified future date

Bilingual court system and legal documentation permitted 
Figure 13: Informal Diglossia in the Legal System in Spoken Contexts in the Observations des tribunaux sur le projet du code criminel de l'an IX

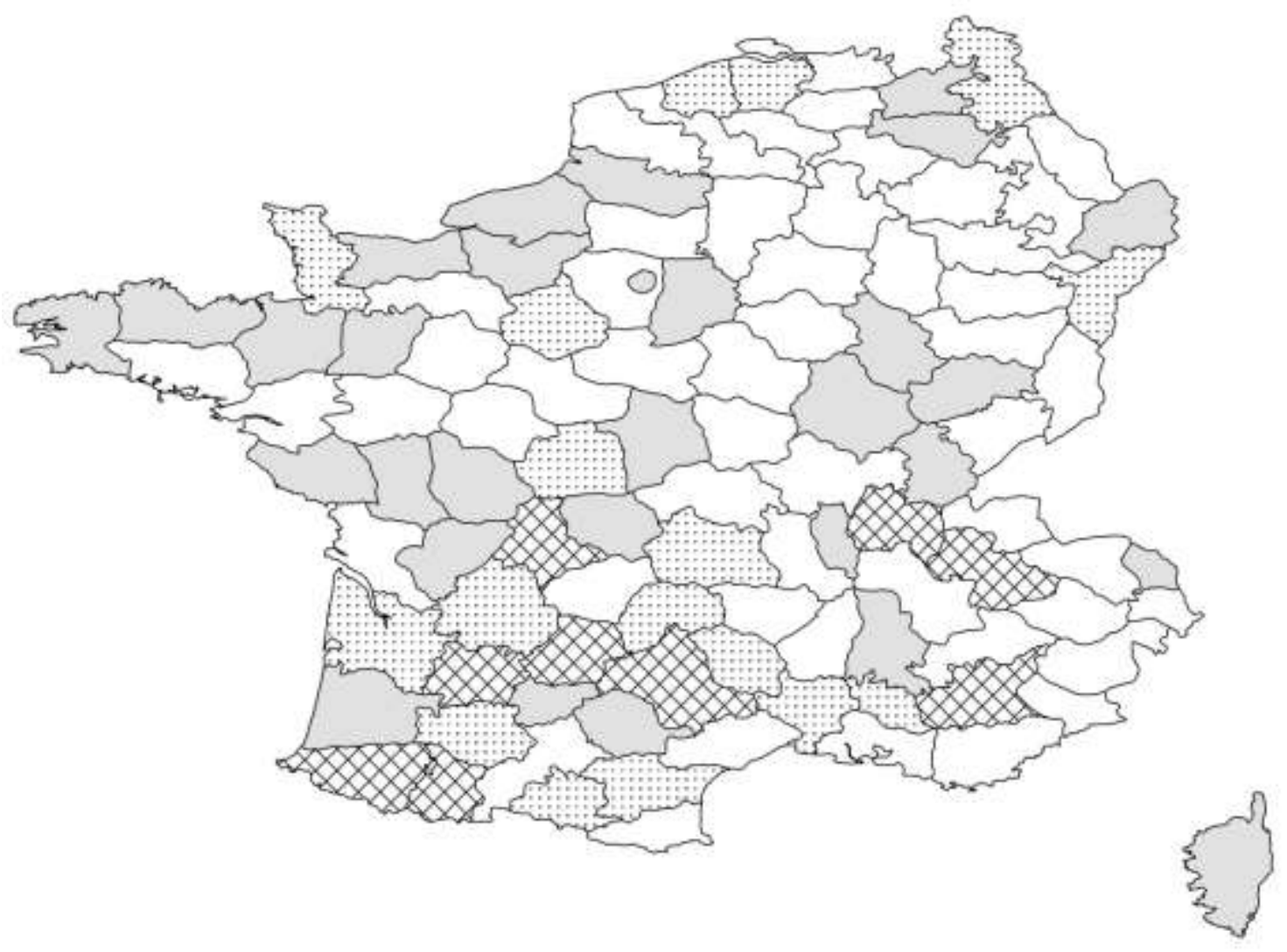

No Indication

Concerns expressed about formalized diglossia

Legal proceedings in languages other than French indicated

No response present in published Observations 
Figure 14: Judges in the resort of the court of appeal of Genoa by origin

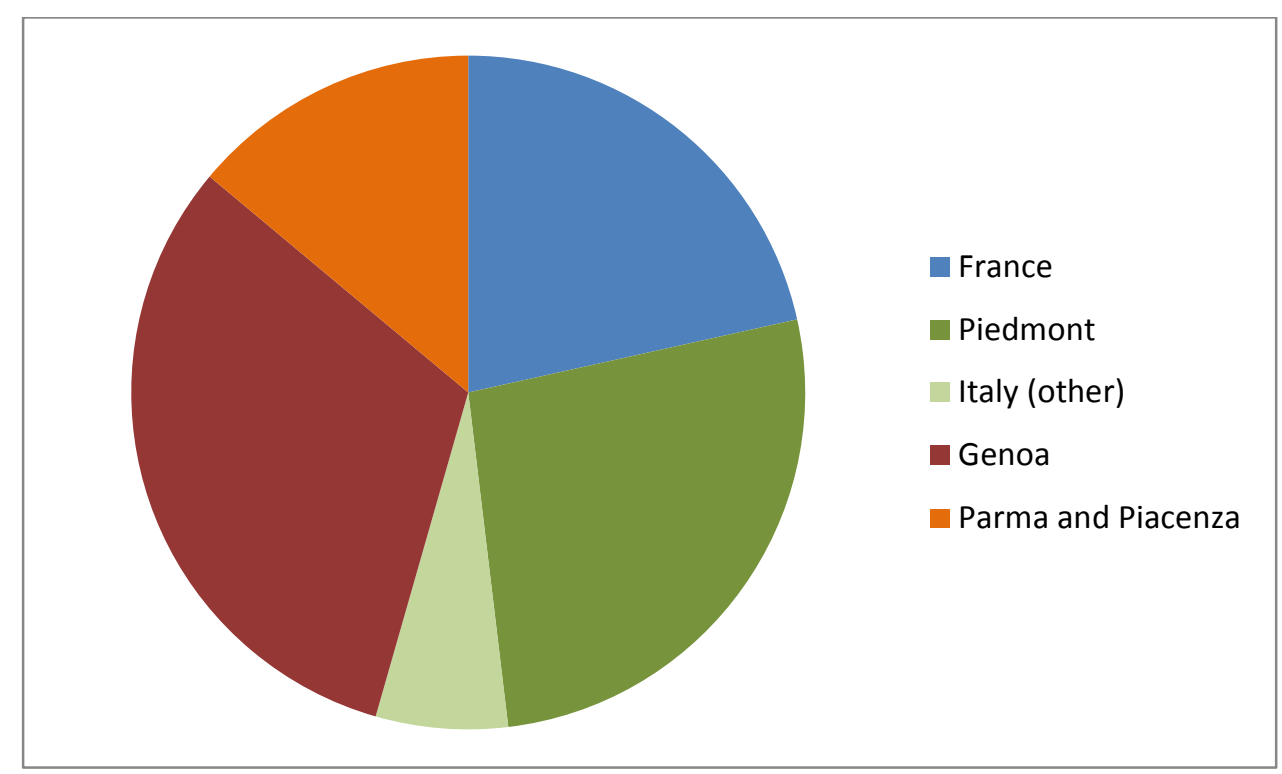

Figure 15: Judges in the jurisdiction of the court of appeal of Trier by origin

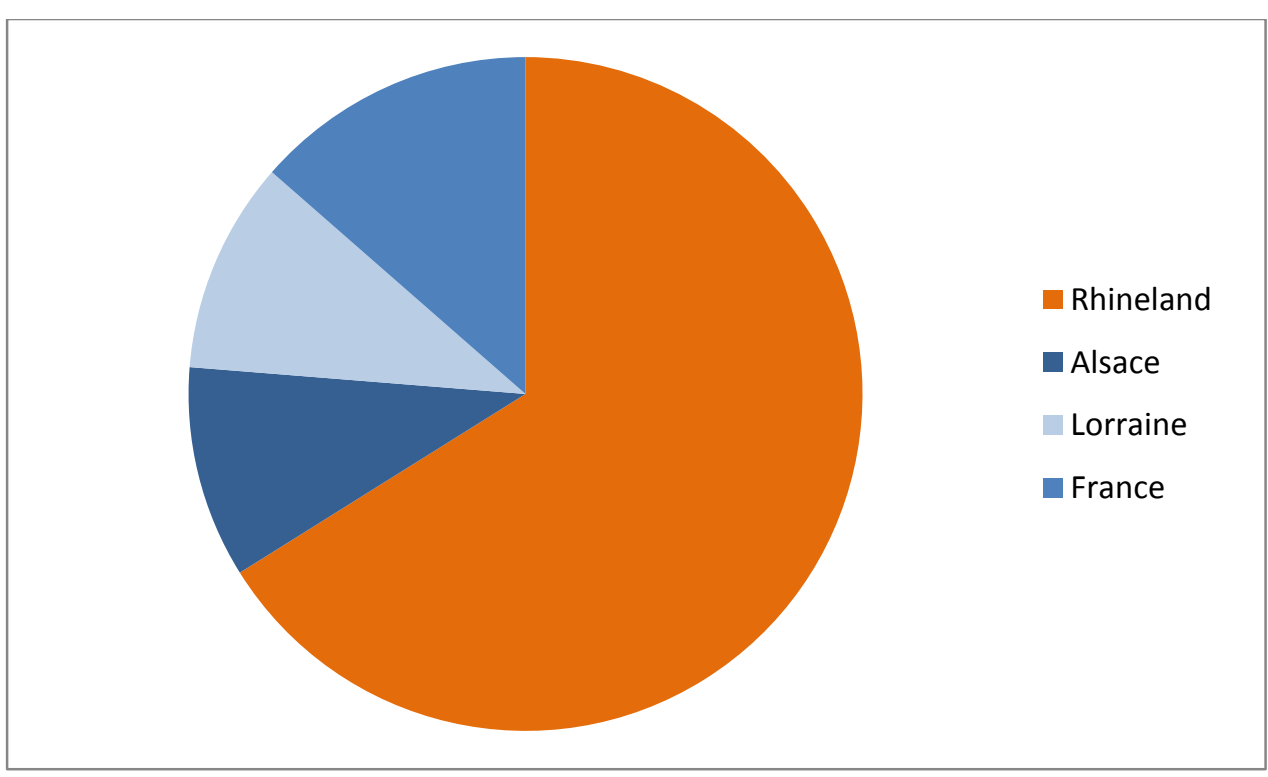


Figure 16: Francophone judges in the jurisdiction of the appeal court of Genoa by origin

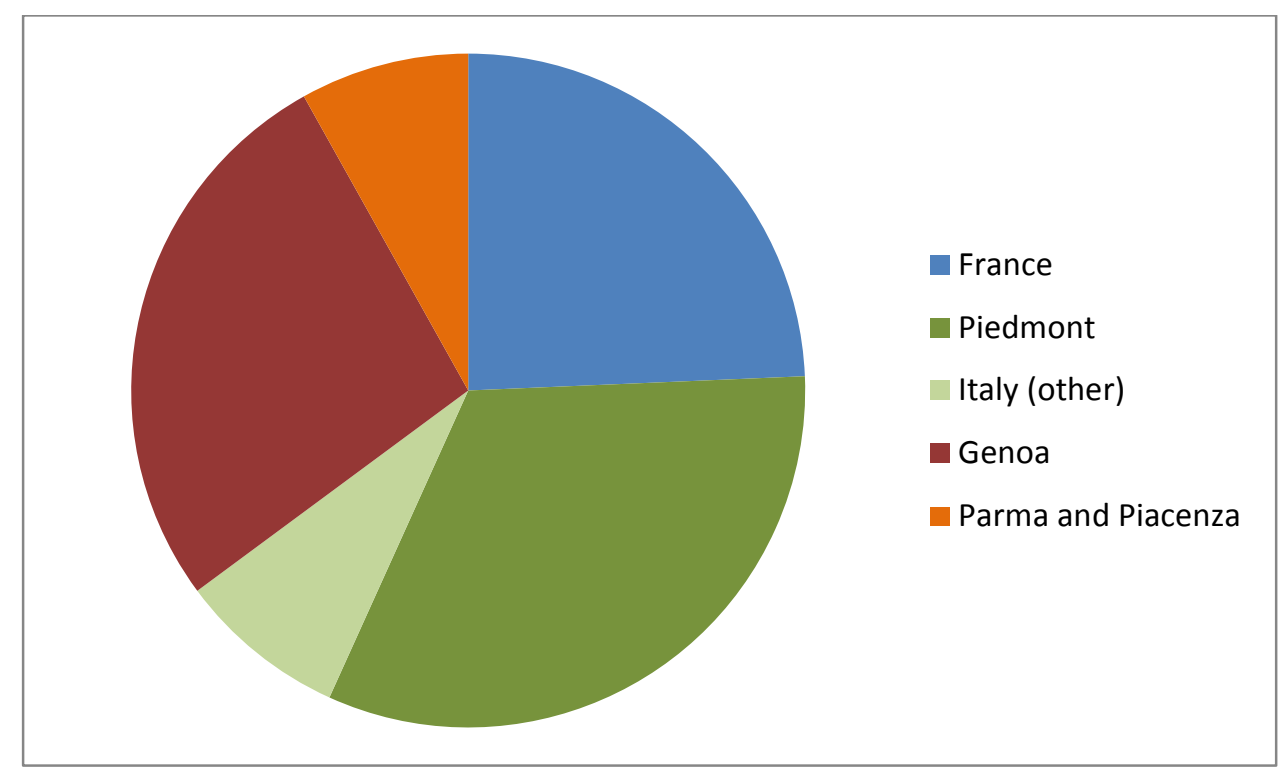

Figure 17: Francophone judges in the jurisdiction of the appeal court of Trier by origin

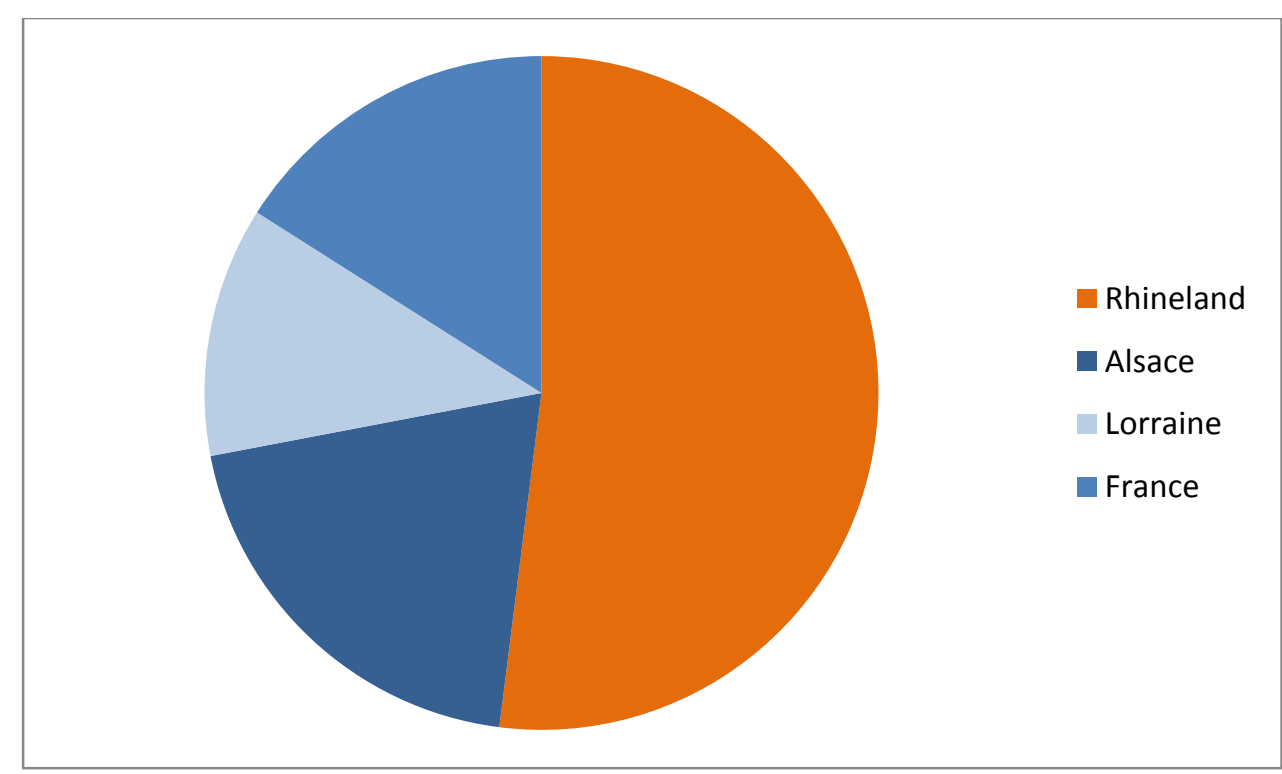


Figure 18: Distribution of Politically Seditious Priests by Department, 1804

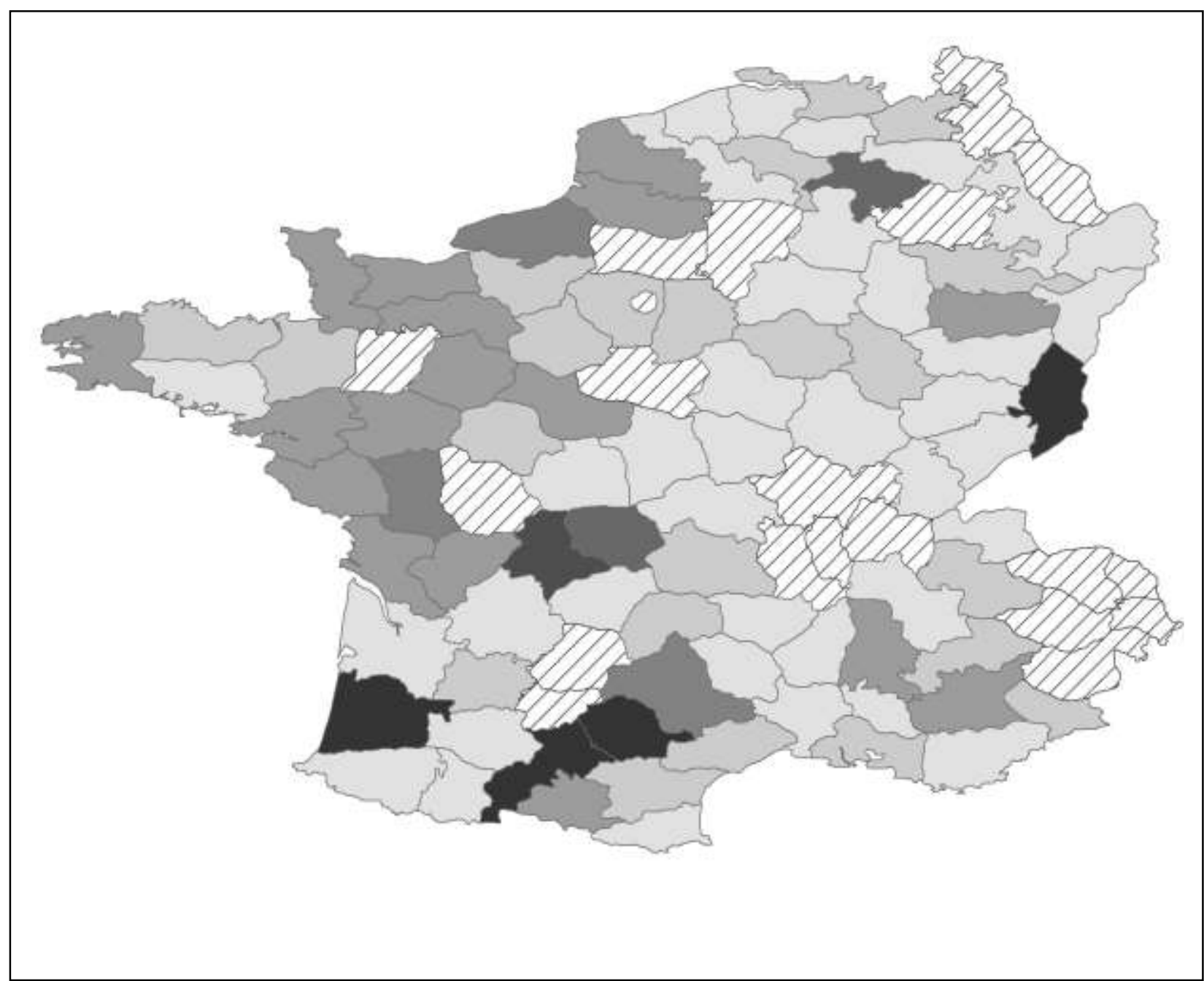

No. of Seditious Priests

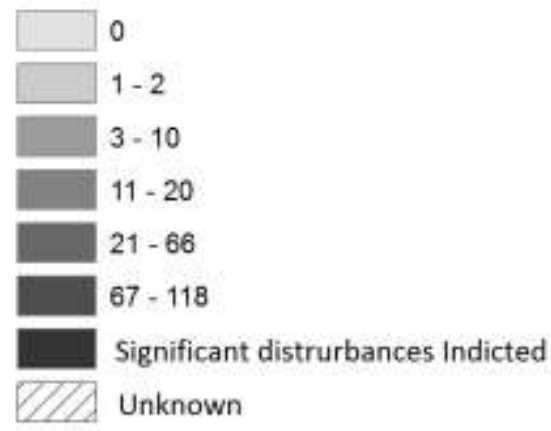




\section{Bibliography}

\section{Manuscript Sources}

Archives Nationales, Paris

Fonds publiques

BB 5 255-267 Rive gauche du Rhin- Cour de Trèves, Mont-Tonnerre, Rhin-et-Moselle, Roër, Sarre BB 5287 Catalogne

BB 5 296-302 Ligurie, Parme- Cour de Gênes, Apennins, Gênes, Montenotte, Taro

BB 5 322-324 Alpes-Maritimes

BB 848 Rapports sur les candidats aux places de greffiers de justice de paix et de tribunaux de police, An XII- An XIV

BB 8101 Nominations de greffiers, 1801-1814. Finistère- Hte. Garonne

F 1 c (III) Côtes du Nord 10 comptes rendus administratifs, An III-1819

F 1 c (III) Haut Rhin 7- comptes rendus administratifs, An VIII-1870

F 121566 Population de la France et langues parlées dans l'Empire

F 17 1344/35 Pièces adressées ou renvoyées au comité d'instruction publique- papiers de Joseph Lakanal

F 171209 Enquête sur les Patois

F 1716141 Organisation de l'instruction publique dans les pays conquis- Provinces Illyriens,

Catalogne, Alpes Maritimes

F 17 9367-8 Rapports des recteurs sur l'instruction primaire

F 1710171 Académie de Liège- Instruction Primaire

F 19453 Police des cultes- Moselle

F 19 818-9 Affaires générales du culte- état des séminaires en Piémont

F 191076 Police des cultes

F 193973 Séminaires- règlements et fonctionnement. An X-1904

F 195438 Catéchisme impériale

F 195555 Police du culte- Missions

F 195598 Police des cultes

F 195660 Police des Cultes- Bouches du Rhône

Fonds de la société des antiquaires

36 AS 3-4 Registres des procès-verbaux des séances de l'académie celtique

Archives départementales des Alpes-Maritimes, Nice

\section{Fonds publiques}

G 1306 Évêché de Vence- conférences ecclésiastiques

2 G 4 Chapitre cathédral de Nice, registre des délibérations

CE 1 T 2 Organisation de l'instruction publique, 1799-1809 
CE 1 T 4 Enseignement en langue française

CE 1 T 5-6 Organisation de l'instruction publique

CE 4 T 1 Affaires culturelles, Diverses- dialectes

Fonds Joseph Lovret

$6 \mathrm{~J} 3$ Usage de la langue française à Nice

Archives départementales des Bouches du Rhône, centre de Marseille

AdBdR 6 M 1601-5 Statistique Villeneuve- Monographs des communes

Archives départementales des Bouches du Rhône, centre d’Aix

$2 \cup 11227$ Cour d'appel d'Aix- parquet général, plaintes contre es patrons-pêcheurs

2 U 2 838, 839, 840, 841, 844, 850, 860, 1053, 1061, 1063, 1064, 1065, 1067, 1068, 2004, 2039,

3861, 3862, 3867, 4396, 4392, 4393, 4577, 4580, 4593 Cour d'appel d'Aix- dossiers de procédure

$2 \cup 4$ 2-3 Procès-verbaux du tribunal criminel d'Aix

96 V 16 Fonds de l'archevêché d'Aix

\section{Archives départementales du Haut Rhin, Colmar}

Fonds publiques

1 T 2 Enquête sur la situation de l'instruction publique

$\checkmark 1$ Recensement des populations des trois cultes

$\checkmark 60$ Opposition entre l'évêque et son clergé

V 61-2 Culte Catholique

$\checkmark 218$ Organisation et police du culte

V 499 Culte protestant- nomination des pasteurs

Fonds du consistoire de Colmar

$101 \mathrm{~J} 1406$ Diverses

$101 \mathrm{~J} 1701$ Écoles

$101 \mathrm{~J} 1704$ Écoles

$101 \mathrm{~J} 1710$ Diverses

$101 \mathrm{~J} 2706$ Diverses 
Archives départementales de la Vaucluse, Avignon

Fonds de la paroisse Saint-Pierre d'Avignon

37 J 37 Sermons

Fonds de la paroisse de Maubec

AdV 31 J 10 Sermons du curé, XVIIle siècle

Bibliothèque Nationale de France, Paris

\section{Nouvelles Acquisitions Françaises}

5910 Patois de la France I- Ain-Eure

5911 Patois de la France II- Gard- Nord

5912 Patois de la France III- Oise- Vienne (hte.)

5913 Patois de la France IV- Limites de la langue française

5914 Patois de la France V- Patois de Montpellier

20080 Linguistique I

\section{Département des manuscrits, bibliothèque municipale de Rouen}

\section{Manuscrits Montbret}

191 Recueil de linguistique

433,489 Notes de M. de Montbret sur le patois

721 Notes sur les limites de la langue française

872 Notes de M. Montbret sur les patois

\section{Printed Primary Sources}

Abus du clergé dénoncé à l'assemblée nationale (Paris, 1790)

Andrews, J.B., Essai de grammaire du dialecte mentonnais, avec quelques contes, chansons et musique du pays (1875)

Annales de la religion ou mémoires pour servir à l'histoire du dix-huitième siècle, par une société des amis de la religion de la patrie (1797)

Annuaire du département des Bouches de la Meuse (The Hague, 1813)

Annuaire statistique, civil, maritime et commercial, du département du Morbihan (Lorient, an XII)

Annuaire statistique du département de Vaucluse (an XII)

Annuaire statistique, historique et administratif du département de l'Orne, pour 1809, avec carte du département, gravures et tableau (Alençon, 1809) 
Annuaire statistique ou almanach des autorités constituées du département de l'Escaut pour l'an XI (Gand, an XI)

Annuaire statistique ou almanach des autorités constituées du département des Bouches de l'Escaut (Middelbourg, 1813)

Auvray, L.M., Statistique du département de la Sarthe (Paris, an X)

Arbaud, D., Chants populaires de la Provence (Aix-en-Provence, 1862 and 1864)

Balbi, A., Introduction à l'atlas ethnographique du globe (Paris, 1826)

Balguerie, P., Tableau statistique du département du Gers (Paris, an X)

Barante, C.I., Observations sur les états de situation du département de l'Aude (Paris, an IX)

- Essai sur le département de l'Aude (Carcassone, an XI)

Beauquier Chansons populaires recueillies en Franche-comté (Paris, 1894)

Belleval, C. de, Notice sur Montpellier (Montpellier, 1804)

Bernard, D., 'Une enquête ministérielle sur les dialectes Bretons sous le Premier Empire' in Annales de Bretagne vol. 60 no.1 (1953) pp.78-83

Berriat-Saint-Prix, J. and Champollion-Figeac, J.J., Notice sur les diverses contrées de l'Isère (Paris, 1811)

Bladé, J.-F., Poésies populaires de la Gascogne. Texte Gascon et traduction française 3 vols. (Paris, 1881 and 1882)

Bodmann, F., Annuaire statistique du département du Mont-Tonnerre, pour l'an 1809 (Mayence, 1808)

Bonnaire, F., Statistique du département des Hautes-Alpes (Paris, an IX)

Borie, N.Y. Statistique du département d'Ille-et-Vilaine (Paris, an IX)

Bossi, C., Statistique générale de la France publiée par ordre de S.M. l'Empereur et Roi sur les mémoires adressées au ministre de l'Intérieure par MM. Les préfet, département de l'Ain (Paris, 1808)

Bossier de Sauvages, P.A., Dictionnaire Languedocien-François, ou choix des mots languedociens les plus difficiles à rendre en François (Nimes, 1756)

Boucqueau, P., Statistique générale de la France, Mémoire statistique du département de Rhin-etMoselle (Paris, an XII)

Boudon de Saint-Amams, J.F., Description abrégée du Lot-et-Garonne (Agen, an VIII) 
Brignant, J. Le, 'Le même parable, traduite en Breton, dans le dialecte de Tréguier', Mémoires de l'académie celtique vol.2 (1808) pp.127-31

Brusle de Valsuzenay, C.I., Tableau statistique du département de l'Aube (Paris, an X)

Bulletin des arrêts de la cour de cassation en matière civile vol.9 nos.4-5 (1807)

Bulletin des lois (1808) nos.25, 51, 72, 187, 222, 292, 329, 381, 459

Cambry, J., Catalogue des objets échappés au vandalisme dans la Finistère: dressé en I'an III (Rennes, 1889)

- Voyage dans le Finistère (Paris, 2000)

Casse, E., 'Vielles chansons du Péigord', Revue de philologie et de littérature vol.17 (1903) pp.114121, 186-263 ; vol.18 (1904) pp.89-102, 195-211 ; vol.19 (1905) pp.48-62, 176-190. 266-283

Casse, E., and Chaminade, E., Les vieilles chansons patoises du Périgord (Périgeux, 1902)

Cavenne, Statistique du département de la Meuse-Inférieure (paris, an X)

Cavoleau, J.A., Description abrégée du département de la Vendée (Fontenay-le-peuple, an IX)

Cénac-Moncaut, J.-E.-M., Littérature populaire de la Gascogne (Paris, 1868)

Champollion-Figeac, J.J., Nouvelles Recherches sur les Patois ou Idiomes Vulgaires de la France et en particulier sur ceux du département de l'Isère (Paris, 1809)

Chèze, J.-B., 'Poésies populaire du Bas-Limousin', Lemouzi vol. 13 (1905)

Chetwode Eustace, J., A Tour through Italy (4 vols., London, 1813)

Cochon de Lapparent, C., Description générale du département de la Vienne (Paris, an X)

Colchen, J.V., Mémoire statistique du département de la Moselle (Paris, an XI)

Collection des pièces imprimées par ordre du concile national de France (Paris, 1797)

Chaise, J.F. de la, Annuaire statistique du Pas de Calais (Arras, an XII)

Champlain, S., Les voyages de la nouvelle France (1632)

Colin, Observations sur le département de la Drôme (Paris, an IX)

Colloque français et breton, ou nouveau vocabulaire (Saint-Brieuc, 1863)

Coquebert de Montbret, E., 'Essai d'un travail sur la géographie de la langue française' in Mélanges sur les langues, dialectes et patois (Paris, 1831)

Corbaz, B., Recueil de morceaux choisis en vers et en prose en patois ... de la Suisse française et terminé par un vocabulaire de mots patois (Lausanne, 1842) 
Dalphonse, F.J.B., Statistique générale de la France, département de I'Indre (Paris, an XII)

- Compte moral de l'administration du département du Gard (Nîmes, 1808-10) 2 vols.

Dauchy, L.J.E., Statistique du département de l'Aisne (Paris, an X)

Daymard, J., Vieux chants populaires recueillis en Quercy (Cahors, 1889)

Debry, J., Statistique générale de la France publié par ordre de S.M. l'Empereur et Roi... Département du Doubs (Paris, an XII)

Degerando, On the Observation of Savage Peoples F.C.T. Moore (trans.) (London, 2004)

Delaistre, G.J.N., Statistique du département de la Charente (Paris, an X)

Delfau, G., Annuaire du département de la Dordogne (Périgueux, an XII)

Denis, Annuaire statistique du département de la Meuse (Commercy, an XII)

Denina, C., 'Dell'uso della lingua francese', C. Denina, C. Marazzini (ed.) Storia delle lingue e polemiche linguistiche (Piacenza, 1985) pp.77-101

Descolins, Liberté égalité. Description abrégée du département de l'Aube (Troyes, an VII)

Description abrégée du département du Morbihan (Paris, an VII)

Desgouttes, Z.H., Tableau statistique du département des Vosges (Paris, an X)

Desgrouais Les gasconismes corrigés (Toulouse, 1819)

Desmousseaux, A.F.E., Tableau statistique du département de l'Ourthe (Liège and Paris, an IX)

Destombes Annuaire statistique du département de la Stura (Coni, 1806)

Dieudonné, C., Statistique du département du Nord (Douai, an XII) 3 vols.

Dorsch, A.J., Statistique du département de la Roer (Cologne, 1804)

Dubois, M., « Remarques sur l'accent Breton-armoricain » in Mémoires de l'Académie Celtique t.5 no.13 (1810)

Dupin, C.F.E., Statistique du département des Deux-Sèvres (Paris, an IX)

- Mémoire statistique du département des Deux-Sèvres (Paris, an XII)

Durat-Lasalle 'Département du Cantal, tableau topographique, statistique et historique du Cantal', Annales de Statistique vol.8 (an XII) pp.402-78

Duval, L., 'L'enquête philologique de 1812 dans les arrondissements d'Alençon \& de Mortagne, Vocabulaires, Grammaire et Phonétique', Actes de la Société Philologique vol.28 (1889) 
Ellgass, B. and Volmar, J., Chansons et Coraules Fribourgeoises. Les Chants du Rond (Fribourg, 1894)

État descriptif du ci-devant district de Lagrasse rédigé par la commission d'agriculture nommé par arrêté de l'administration central du 24 brumaire an VII (Carcassonne, an VIII)

Exposé de la situation de l'Empire française, 10 nivôse an XIII (Paris, 1806)

Faipoult, G.C., Statistique générale de la France, Département de l'Escaut (Paris, an XIII)

Farnaud, P.A., Description abrégée du département des Hautes-Alpes (Paris, an VII)

Fauchet, J.A., Decription abrégée du département du Var (Paris, an IX)

- Mémoire statistique du département du Var (Paris, an XIII)

Fraipont, G., Les montagnes de France III : L'Auvergne (Paris, 1902)

Garnier, G., Description géographique, physique et politique du département de Seine-et-Oise (Paris, an X)

Gazier, A., Lettres à Grégoire sur les patois de France (Paris, 1880)

Gessner, C., Mithridite, de diversis Linguaes (1553)

Gondret, J., Moeurs et coutumes des habitants du Queyras au XIXe siècle (Nyons, 1974)

Grandmougin, C., 'Charmante Sylvie, chanson populaire de la Franche-Comté', La tradition : revue générale des contes, légendes, chants, usages, traditions et arts populaires vol.9 (1887) pp.274-275

Grangent, S.V., Description abrégée du département du Gard, rédigée en brumaire an VIII (Nîmes, an VIII)

Haefelin, F., Les patois romans du canton de Fribourg : Grammaire, choix de poésies populaires, glossaire (Leipzig, 1879)

Hélias, P.J., Le Cheval d'Orgueil : Mémoires d'un Breton au pays bigouden (Paris, 1975)

Herbouville, C.J.F., Statistique du département des Deux-Nèthes (Paris, an X)

Herder, J.G., Outlines of a Philosophy of the History of Man T. Churchill (trans.) (London, 1800)

Huet de Coetlizan, J.B., Statistique du département de Loire-Inférieure (Paris, an X)

- Recerches économique et statistique sur le département de la Loire-Inférieure (Nantes, an XII)

Huguet, J.A., Tableau de situation du département de l'Allier (Paris, an X)

Indy, V. de, Chansons populaires du Vivarais, recueillis et transcrites avec accompagnement de piano (Paris, 1892) 
Jardinet, Statistique du département de Sambre-et-Meuse, rédigé sous les yeux du citoyen Pérès, préfet (Paris, an X)

Jerphanion, G.J., Statisique du département de la Lozère (Paris, an X)

Jessaint, C.L., Description topographique du département de la Marne rédigée par la société d'agriculture, commerce, sciences et arts du département (Paris, an IX)

Johanneau, É., 'Rapport lu à l'Académie celtique sur un ouvrage par A. Lenoir' in Mémoires de l'Académie celtique vol.1 no.2 (1807) pp.144-98

Journal de l'empire, 8 Jan. 1806

Journal d'agriculture et des arts des Hautes-Alpes no. 4 (1807)

Labouliniere, P., Annuaire statistique du département des Hautes-Pyrénées, contenant l'introduction du grand mémoire statistique pour l'an IX (Tarbes, 1807)

Labretonniere, P.L.C., Statisique du département de la Vendée (Paris, an IX)

Lacroix (ed.), Trésors d'archives, Mille ans d'histoire (Nice, 2005)

Lafont du Cujula, C.-M., Annuaire ou description statistique du département du Lot-et-Garonne, rédigé d'après les instructions de S.E. le ministre de l'Intérieur (Agen, 1806)

Lamarque, F., Statistique du département du Tarn (Paris, an IX)

Lambert, L., 'Chansons pastorales du Midi de la France', Revue des langues romanes, vol.44 (1901) pp.5-36

L'ami de la religion et du Roi vol.38, no.2386 (1835)

Laumond J.C.J., Statistique du département du Bas-Rhin (Paris, an X)

Lavallée, J., and Breton, J.B.J., Voyage dans les départements de la France (5 vols., Paris, 1792-1802)

Lecreulx, F.M., Description abrégée du département de la Meurthe (Paris, an VII)

Le Coz, C., 'Déclaration des Évêques de la métropole de Rennes, contre l'emploi de la langue vulgaire dans la Liturgie' in Annales de la religion vol.10

Legendre Luçay, J.B., Description du département du Cher (Paris, an IX)

Legonidec, J.F., 'Parable de l'enfant prodigue mise en Breton, dialecte de Léon', Mémoires de l'académie celtique vol.2 (1808) pp.118-26

Lemaistre, J.G., Travels after the Peace of Amiens through Parts of France, Italy, Switzerland and Germany (3 vols., London, 1806)

Marquis, J.J., Mémoire statistique du département de la Meurthe (Paris, an XIII) 
Mars, A.J.M., Description abrégée du département de l'Orne, rédigé par le lycée d'Alençon (Paris, an IX)

Masson-Saint-Amand, A.-C., Mémoire statistique du département de l'Eure (Paris, an XIII)

Massé, A.-J., Le Parfait notaire ou la science des notaires (1809)

Massicotte and C.M. Barbeau, 'Chants populaires du Canada', Journal of American Folklore vol.32 no.123 (1919) pp.1-89

'Matérieux pour servir à l'Histoire des Dialectes de la Langue française, ou Collection de versions de la parabole de l'enfant prodigue en divers idiômes ou patois de France, in Mémoires de la société royale des antiquaires de France vol.6 (1824) pp.432-545

Mazenod, E. de, Lettres aux oblats de France, 1814-25 (13 vols., Rome, 1977-89)

Mazzini, G., 'The European Question : Foreign Intervention and National Self-Determination', S. Recchia, N. Urbinati A Cosmopolitanism of Nations: Giuseppe Mazzini's Writings on Democracy, Nation Building and International Relations (Princeton, 2009)pp.193-8

M.D.B., Tableau statistique du département de la Dyle, divisé en trois arrondissements communaux (Brussels, an XIII)

Ménétra, J.L., Journal de ma vie (Paris, 1982)

Mercadier de Belesta, J.B., Ébauche d'une description abrégée du département de l'Ariège (Foix, an IX)

Merlin, P.A., Répertoire universel et raisonné de jurisprudence, vol. 6 (Paris, 1808)

Merson, L., Annuaire statistique du département de l'Ems-Supérieure (Osnabruck, 1812)

Michel d'Eyguieres, J.E., Statistique du département des Bouches-du-Rhône (Paris, an XI)

Millin, A.L., Voyage dans les départemens du midi de la France, (5 vols., Paris, 1807- 1811

- Voyage en Savoie, en Piémont, à Nice, à Gênes (2 vols., Paris, 1816)

Montalivet, J.P., Exposé de la situation de l'Empire présenté au corps législatif, dans sa séance du 25 Février 1813 (Paris, 1813)

Mistral, F., Lou tresor dòu Felibrige ou dictionnaire Provençal-Français (2 vols., Arles, 1878)

Molard, E., Dictionnaire du mauvais langage ou Recueil des expressions et des phrases usitées en France, et notamment à Lyon (Lyon, 1797)

Monteil, A.A., Description du département de l'Aveyron (Rodez and Paris, an X) 2 vols.

Necker, J., Compte rendu au Roi (Paris, 1781)

Negrin, E., Les Promenades de Nice (Nice, 1867) 
Nodier, Comment les patois furent détruits en France, conte fantastique (Paris, 1835)

Oberlin, J.J., Essai sur le patois lorrain des environs du Comté du Ban de la Roche, fief Royal d'Alsace (Strasbourg, 1775)

Observations des tribunaux d'appel sur le projet de code criminel (2 vols., Paris, 1804)

Observations des tribunaux criminels sur le projet de code criminel (6 vols., Paris, 1804)

'Observations sur les nouveaux départemens de la rive gauche du Rhin', in Le Nécessaire ou courrier du corps législatif 25 Thermidor an VII (12 Aug. 1799)

Olivet, F. d', Le Troubadour : Poésie Occitanique du XIIle siècle (4 vols., Paris, 1803)

'Patois', D. Diderot and J. le Rond D'Alembert (eds.) Encyclopédie, ou dictionnaire raisonné des sciences, des arts et des métiers, V.12 p.174 University of Chicago: ARTFL Encyclopédie Project (Spring 2011 Edition) http://artflx.uchicago.edu/cgi-

bin/philologic/getobject.pl?c.11:252.encyclopedie0311 accessed 19/02/2012

Pallas, P.S., Linguarum totius orbis vocabularia comparativa (2 vols., St Petersburg, 1787-9)

Papon, S., Voyage dans le département des Alpes-Maritimes, avec la description de la ville et du terroir de Nice, de Menton, de Monaco etc. (Paris, 1804)

Pazzis, M.S. de, Mémoire statistique sur le département de Vaucluse (Carpentras, 1808)

Pellas, S.A., Dictionnaire provençal et françois dans lequel on trouvera les mots provençaux \& quelques phrases \& proverbes expliquex en françois (Avignon, 1823)

Perrin-Dulac, F.M., Description générale du département de l'Isère (Grenoble, 1806) 2 vols.

Pietry, Statistique du département du Golo (Paris, an X)

Pieyre, J., Mémoire statistique du département de Lot-et-Garonne (Paris, an X)

Pineau, L., Le folklore de Poitou (Paris, 1892)

Poitevin, 'Réflexions sur quelques étymologies languedociennes qui dérivent directement du Grec', Recueil des bulletins de la société libre des sciences et belles-lettres de Montpellier vol.2 no.16 (1805)

Poyart Flandricismes, wallonismes et expressions impropres dans le langage français (Bruxelles, 1806)

Prières du matin et du soir et quelques cantiques provençaux et françois à l'usage des Missions des RR. Peres Jésuites à Marseille (Marseille, 1724)

Projet du code criminel, avec les observations des rédacteurs, celle du tribunal de cassation et le compte-rendu par le Grande-Juge (Paris, 1804)

Puymaigre, T.B. de, Chants populaires recueillis dans le pays messin (Metz and Paris, 1865) 
Quenin, D.J., Statistique du canton d'Orgon (Arles, 1838)

Recueil officiel des actes du consistoire général (Strasbourg, 1841)

Ritz, J., Les chansons populaires de la Haute Savoie (Annecy, 1900)

Robert, L.J.M., L'hermite de Saint-Jean, ou Tableau des fêtes marseillaises lors de l'arrivée et durant le séjour de S.A.R. Madame, duchesse d'Angoulême, à Marseille nos.7-8 (1823)

Rossat, A., 'Chants patois jurassiens', Archives suisses des traditions populaties- Schweizerishces Archiv für Volkskunde vol.5 (1901) pp.81-112, 201-227

Roux, P. Le, 'Un texte dialectal de Haute-Cornouaille en 1811', Annales de Bretagne vol.60 no.1 (1953) pp.84-91

Saurine J.B. 'Avis de l'évêque de Dax sur le sacramentaire français' in Annales de la religion vol.10 (1799) pp.49-96

Saussay, A., Statistique du département du Mont-Blanc (Paris, an IX)

Saint-Amans, J.F. Boudon de, Description abrégée du département de Lot et Garonne (Agen, an VIII)

Schnakenberg, J.F., Tableau synoptique et comparatif des idiomes populaires de la France (Berlin, 1840)

'Série de questions', Mémoires de l'Académie celtique vol.1 no.1 (1807) pp.72-86

Serviez, E.G.R., Statistique du département des Basses-Pyrénées (Paris, an X)

Simon, Premières années (Paris, 1901)

Sirey, J.B., Tableau alphabétique des lois et arrêts (Paris, 1811)

Sismondi, J.G.L., Statistique du département du Léman, publiée d'après le manuscrit original et présentée par H.O. Pappe (Genève, 1971)

Staël, Mme de, De l'Allemagne (Paris, 1968)

Tarbé, P., Romancéro de Champagne (Reims, 1864) vol.2

Tassoni, G., Arti e tradizioni popolari: Le inchieste napoleoniche sui costumi e le tradizioni nel regno italico (Bellinzona, 1973)

Texier-Olivier, L., Statistique générale de la France, département de la Haute-Vienne (Paris, 1808)

Tiersot, J., Chansons populaires recueillies dans les alpes-française, Savoie et Dauphiné (Grenoble, 1903) 
Toselli, J.-B., Rapport d'une conversation sur le dialecte niçois, dissertations sur son origine et ses progrès, aperçu orthographique et pièces justificatives suivi de tableaux différentes langues et d'un glossaire (Nice, 1864)

Trébucq, S., La chanson populaire et la vie rurale des Pyrénées à la Vendée (Bordeaux, 1912) vol.2

Trouvé, C.J., États de Languedoc et département de l'Aude avec carte et gravures (Paris, 1818)

Vergnes, J.P. de, Mémoire sur la statistique du département de la Haute-Saône (Paris, an X)

Verneilh-Puyraseau, J.J., Mémoire sur le département de la Corrèze (Tulle, an IX)

-Statistique générale de la France : département du Mont-Blanc (Paris, 1807)

Verniac de Saint-Maur, R. de, Description physique et politique du département du Rhône (Paris, an $\mathrm{X})$

Vial, J.B.C., Le premier venu, ou six lieues de chemin (Paris, 1801)

Villeneuve, D. de, Statistique du département des Bouches-du-Rhône (4 vols, Marseille, 1821, 1824, $1826,1829)$

- Voyage dans la vallée de Barcelonnette (Agen, 1815)

Viry, J.M., Statistique générale de la France, Mémoire statistique du département de la Lys (Paris, an XII)

Vitalis, J.B., Annuaire statistique du département de la Seine-Inférieure (Rouen, an XII)

Volney, C.F., 'Rapport fait à l'académie celtique sur l'ouvrage russe de M. le professeur Pallas intitulé : Vocabulaires comparés des langues de toute la Terre', Mémoires de l'académie celtique vol.1 (1807) pp.99-135

-Questions de statistique à l'usage des voyageurs (Paris, 1813)

Young, A., Travels in France during the years 1787, 1788 and 1789 vol.1 (Bury St. Edmunds, 1792)

\section{Secondary Sources}

Aarsleff, H., From Locke to Saussure: Essays on the Study of Language and Intellectual History (London, 1982)

Aaslestad, K., Place and Politics: Local Identity, Civic Culture, and German Nationalism in North Germany during the Revolutionary Era (Leiden, 2005)

Agulhon, M., La République au village: Les populations du Var de la révolution à la lle République (Paris, 1979)

Anderson, B., Imagined Communities: Reflections on the Origins and Spread of Nationalism (London, 2006) 
Armengaud, A., 'Enseignement et langues régionales au XIXe siècle ; l'exemple du Sud-Ouest Toulousain', C. Gras and G. Livet (eds.) Régions et régionalisme en France : du XVIIle siècle à nos jours (Paris, 1977) pp.265-272

Aston N., Religion and Revolution in France, 1780-1804 (Basingstoke, 2000)

Auroux S., Linguistique et anthropologie en France, 1600-1800 (Paris, 1982)

Auslander, L., Cultural Revolutions: The Politics of Everyday Life in Britain, North America and France (Oxford, 2009)

Avaza, M., and G. Laferté 'Dépasser la " construction des identités ? " Identification, Image Social, Appartenance' Genèses vol.61, no.4 (2005) pp.154-67

Balibar R., L'institution du français; essai sur le colinguisme des Carolingiens à la République (Paris, 1985)

Barral, P., 'Depuis quand les paysans se sentent-ils français?', Ruralia no.3 (1998) pp.7-21

Baycroft, T., Culture, Identity and Nationalism: French Flanders in the Nineteenth and Twentieth Centuries (Woodbridge, 2004)

Bayle, L., Procès de l'Occitanisme (Toulouse, 1975)

Bayly, C.A., The Birth of the Modern World, 1790-1914: Global Connections and Comparisons (Oxford, 2004)

Bec P., La langue occitane (Paris, 1963)

Bell, D., 'Nation-Building and Cultural Particularism in Eighteenth Century France: The Case of Alsace', Eighteenth Century Studies vol.21 no.4 (1988) pp.472-490

2001)

- The Cult of the Nation in France: Inventing Nationalism, 1680-1800 (Cambridge Mass.,

Belmont, N., Aux origines de l'ethnographie française: L'académie celtique (1804-1812) (Paris, 1995)

Bergeron, L. and Chaussinand-Nogaret, G., Les Masses de granit: Cent mille notables du Premier Empire (Paris, 1979)

Bernard D., 'Une enquête ministérielle sur les dialectes bretons sous le Premier Empire', Annales de Bretagne, vol.60 no.1 (1953)

Bernard H.C., Education and the French Revolution (London, 1969)

Bernet, J., 'Jacques Cambry, premier préfet de l'Oise (mars 1800- avril 1802) et sa Description du département de l'Oise (1803), ouvrage précurseur sur l'ethnologie du département', in A. de Mathan (ed.), Jacques Cambry, un Breton des Lumières au service de la construction nationale (Brest, 2008) pp.85-102 
Bertrand, R., 'Usages religieux du provençal aux XVIIle et XIXe siècles', M. Lagrée (ed.) Les Parlers de a foi, Religion et langues régionales. (Rennes, 1995) pp.107-116

— 'Le « langage patois » des " hommes de la nature »: La folklorisation des prud'hommespecheurs de Marseille dans le dernier tiers du XVIII siècle', L'invention du midi: représentations du sud pendant la période révolutionnaire AMIRAS/REPÈRES no. 15-20 (1987) pp.9-26

Bianchi S., La révolution culturelle de l'an II: élites et peuples (Paris, 1982)

Bochmann K. , 'La France napoléonienne et ses langues', in G. Kremnitz (ed.) Histoire sociale des langues de France (Rennes, 2013)

Bertho, C., 'L'invention de la Bretagne : Genèse social d'un stéréotype' Actes de la recherche en sciences sociales vol.35 (1980) pp.45-62

Bloomfeld, L., Language (London, 1933)

Bourdieu, P., Bourdieu Language and Symbolic Power (Cambridge, 1991)

- 'Rethinking the State: Genesis and Structure of the Bureaucratic Field', L.J.D. Wacquant and S. Farage (trans.) G. Steinmetz (ed.) State/Culture: State-Formation after the Cultural Turn (London: 1999)

Bourguet, M.N., Déchiffrer la France : La statistique départementale à l'époque napoléonienne (Paris, 1988)

Britto, F., Diglossia : A Study of Theory with Application to Tamil (Washington, 1986)

Broers, M., 'Cultural Imperialism in European Context? Political Culture and Cultural Politics in Napoleonic Italy', Past and Present no.170 (2001) pp.152-180

- Europe under Napoleon, 1799-1815 (Oxford, 1996)

- 'La mission de Joseph-Marie Degérando en Haute-Catalogne en 1812 : La loi universelle de l'empire et la dernière réunion', Napoléon, Bayonne et l'Espagne : Actes du colloque organisé par la société des sciences, lettres et arts à l'occasion du bicentenaire de l'entrevue de Bayonne (Paris, 2011)

- Napoleon, Soldier of Destiny (London, 2014)

- 'Napoleon, Charlemagne and Lotharingia: Acculturation and the Boundaries of Napoleonic Europe', The Historical Journal vol.44 (2001) pp.135-154

- Napoleonic Imperialism and the Savoyard Monarchy, 1773-1821: state building in Piedmont (Lewiston, 1997)

- The Napoleonic Empire in Italy: Cultural Imperialism in a European Context? (Basingstoke, 2005)

- 'The Napoleonic Empire', A. Forrest and P.H. Wilson (eds.), The Bee and the Eagle: Napoleonic France and the End of the Holy Roman Empire (Basingstoke, 2009) pp.65-82 
Broudic, F., La pratique du breton de l'ancien régime jusqu'à nos jours (Rennes, 1995)

- L'interdiction du breton en 1902: La Ille république contre les langues régionales (Spézet, 1996)

- Parler Breton au XIXe siècle : Le nouveau sondage TMO régions (Brest, 2009)

Brown, R., and Gilman, A., 'The Pronouns of Power and Solidarity', T.A. Sebeok (ed.), Style in Language (Cambridge Mass., 1960) pp.253-76

Brun, A., Recherches historiques sur l'introduction de français fans les provinces du midi (Pairs, 1923)

- 'En Langage maternel françois', Le Français moderne 19, (1951) pp.81-6

- La Langue française en Provence, de Louis XIV au Félibrige (Geneva, 1972)

Brunel C., 'L'académie bretonne au grand séminaire de Quimper' in M. Lagrée (ed.) Les parlers de la foi: Religion et langues régionales (rennes, 1995) pp.31-46

Brunet, M., Le Roussillon : Société contre l'état 1780-1820 (Toulouse, 1986)

Brunot, F., Histoire de la langue française des origines à nos jours (13 vols., Paris, 1966-79)

Brun-Trigaud G., Le croissant : Le concept et le mot, contribution à I'histoire de la dialectologie française au XIXeme siècle (Lyon, 1990)

Burguière, A., 'Monarchical Centralization and the Birth of Social Sciences: Voyagers and Statisticians in Search of France at the End of the Eighteenth Century' in R. M. Schwartz and R. A. Schneider (eds.) Tocqueville and Beyond: Essays on the Old Regime in honour of David D. Bien (London: 2003) pp.226240

Burke P. , Languages and Communities in Early Modern France (Cambridge, 2004)

- Towards a Social History of Early Modern Dutch (Amsterdam, 2005)

Byrnes, J., 'The Relationship of Religious Practice to Linguistic Culture: Language, Religion and Education in Alsace and the Roussillon, 1860-1890', Church History: Studies in Christianity and Culture vol.68 no.3 (1999) pp.598-626

Castan Y., 'Les Languedociens du XVIIIe siècle et l'obstacle de la langue écrite', France du nord et France du midi, Actes du $96^{e}$ Congrès national des sociétés savantes Toulouse 1971 (Paris, 1976) i, pp.73-84

Cerquiglini B., Les Langues de France Rapport au ministre de l'Education Nationale, de la Recherche et de la Technologie et au Ministre de la Culture et de la Communication (Paris, 1999) http://www.dglf.culture.gouv.fr/lang-reg/rapport cerquiglini/langues-france.html accessed $\underline{18 / 02 / 2012}$

Certeau, M. de, Julia, D., and Revel, J., 'La beauté du mort' dans Certeau, M. de, La culture au pluriel (Paris, 1993) 
- Une politique de la langue : la Révolution française et les patois : l'enquête de Grégoire (Paris, 2002)

Chambers J.K. and P. Trudgill Dialectology (Cambrdige, 1998)

Chanet, J.-F., L'Ecole républicaine et les petites patries (Paris, 1996)

Chappey J.-L., La société des observateur de l'homme, 1799-1804 : des anthropologues au temps de Bonaparte (Paris, 2002)

Chartier, R., The Cultural Origins of the French Revolution (London, 1991)

- 'The Saint-Malo Geneva Line', P. Nora (ed.) A. Goldhammer (trans.) Realms of Memory: The Construction of the French Past vol.1: Conflicts and Divisions (Chichester, 1996) pp.467-96

Chassang P. Le grand séminaire de Saint-Flour (Saint-Flour, 1994)

Cholvy, G., and Hilaire, Y.-M., Histoire religieuse de la France, 1800-1880 (Toulouse, 2000)

- 'Le Catholicisme populaire en France au XIXe siècle' in B. Plongeron et R. Plannet (eds.) Le christianisme populaire (Paris, 1976)

- Christianisme et société en France au XIXe siècle 1790-1814 (Paris, 2001)

Church, C.H., Revolution and Red Tape: The French Ministerial Bureaucracy, 1770-1850 (Oxford, 1981)

Clanché, F., 'Langues régionales, langues étrangères : de l'héritage à la pratique', INSEE Première no. 830 (2002) http://www.dglflf.culture.gouv.fr/Igfrance/IP830.pdf accessed 22/04/2013

Cohen, P., Courtly French, Learned Latin and Peasant Patois: The Making of a National Language in Early Modern France (Unpublished PhD thesis, Princeton University, 2001)

Coirault P., Delaure G., Fédoroff Y. and S. Wallon Répertoire des chansons françaises de tradition orale 1. La poésie et l'amour (Paris, 1996)

Coller I., Arab France : Islam and the Making of Modern Europe (London, 2011)

Cobb, R., 'The Revolutionary Mentality in France, 1793-4', History vol.42 no.147 (1957) pp.181-96

Corbin, A., The Life of an Unknown: The Rediscovered World of a Clog Maker in Nineteenth Century France (Chichester, 2001)

- The Lure of the Sea: The Discovery of the Seaside in the Western World, 1750-1840 (London, 1995)

- Village Bells: Sound and Meaning in the Nineteenth Century French Countryside (Columbia, 1998) 
Courthiade M., 'Le rromani et les autres langues en usage parmi les Rroms, Manouches et Gitans', in G. Kremnitz (ed.) Histoire sociale des langues de France (Rennes, 2013) pp.567-80

Cubitt G., The Jesuit Myth : Conspiracy Theory and Politics in Nineteenth Century France (Oxford, 1993)

Davis J.A., Conflict and Control: Law and Order in Nineteenth Century Italy (Basingstoke, 1988)

Davis, N.Z., Society and Culture in Early Modern France: Eight Essays (Stanford, 1975)

Degerando J.M. , The Observation of Savage Peoples F.C.T. Moore (trans.) (London, 2004)

Del Vento C., 'La première fortune d'Alfieri en France : de la traduction française du « Panégyrique de Trajan par Pline » (1787) à la traduction des " oeuvres dramatiques " (1802)', Revue des études italiennes vol.50 no.1/2 (2004) p.215-28

Destrem, J., Les déportations du Consulate et de l'Empire, d'après les documents inédits (Paris, 1885)

Dunlop, C.T., 'Mapping a New Kind of European Boundary: The Language Border between France and Germany', Imago Mundi vol.65 no.2 (2013) pp.253-67

Dunne, J., 'Napoleon's Mayoral Problem: Aspects of State Community Relations in Post-

Revolutionary France', Modern and Contemporary France vol.8 no.4 (2000) pp.479-91

Elfenbein, A., Romanticism and the Rise of English (Stanford, 2009)

Engelbrecht, J., 'The French Model and German Society: The Impact of the Code Penal on the Rhineland', X. Rousseau, M.-S. Dupont-Bouchat, C. Vael (eds) Révolutions et justice pénale en Europe: Modèles français et traditions nationales, 1780-1830 (Paris, 1999)

Englund, S., 'Monstre Sacré: The Question of Cultural Imperialism and the Napoleonic Empire', The Historical Journal vol.51 no.1 (2008) pp.215-250

Esdaile, C., Fighting Napoleon: Guerrillas, Bandits and Adventurers in Spain, 1808-1814 (New Haven, 2004) 2005)

- Popular Resistance in the French Wars: Patriots, Partisans and Land Pirates (Basingstoke,

Evans R.J.W., 'Language and State Building, the Case of the Habsburg Monarchy' in Austrian History Yearbook vol. xxxv 2004 p.1-24

Fabian, J., Time and the Other: How Anthropology Makes its Object (New York, 2014)

Fergusson, C.A., 'Diglossia', Word vol. 15 (1959) pp.325-40 reprinted in P.P. Giglioli (ed.) Language and Social Context (Harmondsworth, 1972)

Félix, J., 'The Problems with Necker's Compte Rendu au Roi (1781)', J. Swann and J. Félix (eds.), The Crisis of the Absolute Monarchy: From the Old Regime to the French Revolution (Oxford, 2013) pp.107-125 
Fishman, J., 'Bilingualism With and Without Diglossia, Diglossia With and Without Bilingualism', Journal of Social Issues vol.22 no.2 (1967) pp.29-38

- In Praise of the Beloved Language: A Comparative View of Positive Ethnolinguistic Consciousness (Berlin, 1997)

-Languages and Nationalism, Two Integrative Essays (Rowley, 1975)

- 'The Relationship between Micro- and Macro-Sociolinguistics in the Study of Who Speaks What Language to Whom and When', J.B. Pride and J. Holmes (eds.) Sociolinguistics (Harmondsworth, 1972)

Ford, C., Creating the Nation in Provincial France: Religion and Political Identity in Brittany (Princeton, 1993)

- 'Religion and Popular Culture in Modern Europe' in The Journal of Modern History Vol. 65 no. 1 (1993) pp.152-75

Forrest, A., Napoleon's Men: The Soldiers of the Revolution and Empire (London, 2006)

- Conscripts and Deserters: The French Army and Society during the Revolution and Empire (Oxford, 1989)

Fox, A., Oral and Literate Culture in England, 1500-1700 (Oxford, 2000)

Froeschlé-Chopard M.H., 'Entre peuple et hiérarchie: l'échec d'un pastorale', in Dix-huitième siècle no.12 (1980) pp.271-92

- La Religion populaire en Provence orientale au XVIIle siècle (Paris, 1980)

Furet, F., and Ozouf, J., Reading and Writing: Literacy in France from Calvin to Jules Ferry (Cambridge, 1982)

Gardener-Chloros, P., 'Tu/Vous Choices: An Act of Identity?', W. Ayres-Bennett and M.C. Jones (eds.) The French Language and Questions of Identity (London, 2007) pp.106-16

Gawelik K., Sources de la codification pénale à la lumière des observations des tribunaux sur le projet de Code criminel de I'an IX (Lille, 2008)

Gellner, E., Nations and Nationalism (Oxford, 1983)

Gemie, S., Brittany 1750-1950, the Invisible Nation (Cardiff, 2007)

Gerson, S., The Pride of Place: Local Memories and Political Culture in Nineteenth Century France (London, 2003)

Gildea R., Education in Provincial France, 1800-1914 (Oxford, 1983)

-The Past in French History (London, 1994)

Ginderachter, van M. and Beyen, M., (eds.), Nationhood from Below: Europe in the Long Nineteenth Century (Basingstoke, 2012) 
Godlewska A., Geography Unbound : French Geographic Science from Cassini to Humboldt (London, 1999)

Goody, J., The Domestication of the Savage Mind (Cambridge, 1977)

Grab, A., 'Army, State and Society: Conscription and Desertion in Napoleonic Italy', Journal of Modern History vol.67 no.1 (1995) pp.25-54

- 'Napoleon: A civilizing missionary or a pragmatic imperialist?', Selected Papers, Consortium on Revolutionary Europe 1750-1850 (2008) pp.238-249

- 'State Power, Brigandage, and Rural Resistance in Napoleonic Italy', European History Quarterly vol.25 no.1 (1995) pp.39-70

Grevet R., L'avénement de l'école contemporaine en France: 1789-1835 (Lille, 2001)

Hadjadj, D., Parlers en contact aux confins de l'Auvergne et du Forez (Clermont-Ferrand, 1983)

Harlow, R., 'Some Languages are Just Not Good Enough', L. Bauer and P. Trudgill (eds.) Language Myths (London, 1998) pp.9-13

Harris R. , 'Introduction' in R. Harris (ed.) Foundations of Indo-European Comparative Philology 18001850 (13 vols., London, 1999)

Haugen E., 'Dialect, Language, Nation' in American Anthropologist vol. 68 no. 4 (Aug. 1966) pp. $922-$ 35

Hechter, M., Internal Colonialism: The Celtic Fringe in British National Development (London, 1975)

Heller M., 'Introduction', M. Heller (ed.) Codeswithching: Antropological and Sociolinguistic Perspectives (Berlin, 1988) pp.1-24

Henry, F.G., 'From the First to the Fifth Republic: Antoine de Rivarol, Johann Christoph Schwab, and the Latest Lingua Franca', The French Review vol.77 no.2 (2003)

- Language, Culture and Hegemony in Modern France (Birmingham Al, 2008)

Higonnet, P., 'The Politics of Linguistic Terrorism and Grammatical Hegemony during the French Revolution', Social History vol. 5 no.1 (1980) pp.41-69

Hilaire J., 'L'influence du modèle judicaire français en Europe sous la Révolution et l'Empire : Un Cliché en question' in Influence du modèle judicaire français en Europe sous la Révolution et I'Empire : Actes du colloque tenu à I'université de Lille II, Juin 1998 (Lille, 1999) pp.1-7

Hopkin, D., Voices of the People in Nineteenth Century France (Oxford, 2012)

Hroch, M., Comparative Studies in Modern European History: Nation, Nationalism and Social Change (Aldershot, 2007) 
Hudson, A., 'Outline of a Theory of Diglossia', International Journal of the Sociology of Language vol.157 (2002) pp.1-48

Hunt, L., Politics, Culture and Class in the French Revolution (London, 2004)

Hymes D., Foundations in Sociolinguistics: An Ethnographic Approach (Philadelphia, 1974)

Jacobson S., Catalonia's Advocates: Lawyers, Society and Politics in Barcelona, 1759-1900 (Chapel Hill, 2009)

Jochnowitz G., Dialect Boundaries and the Question of Franco-Provençal (The Hague, 1973)

Johnson H.C., The Midi in Revolution. A Study of Regional Political Diversity, 1789-1793 (Princeton, 1986)

Jones P.M., The Peasantry in the French Revolution (Cambridge, 1988)

Joseph, G.M., and D. Nugent, 'Popular Culture and State Formation in Revolutionary Mexico', G. M. Joseph and D. Nugent (eds.), Everyday Forms of State Formation: Revolution and the Negotiation of Rule in Modern Mexico (London: 1994) pp.3-23

Joseph J.E., Minority Languages and Group Identity: Cases and Categories (Amsterdam, 2010) Kain, R.J.P., and Baigent, E., The Cadastral Map in the Service of the State: A History of Property Mapping (London, 1992)

Kamusella, T., The Politics of Language and Nationalism in Modern Central Europe (Basingstoke, 2009)

Keller, H.E., 'L'enquête de Coquebert de Montbret dans la Lozère' Mélanges de philologie romane offerts à Charles Comproux vol. 2 (Montpellier, 1978)

- 'Le Parler du Bugey au début du XIXe siècle', Espace Romans, études de dialectologie et de géolinguistique offertes à Gaston Tuaillon (Grenoble, 1989) vol. 2 pp. 161-87

- 'L'enquête de Coquebert de Montbret dans la Lozère', Mélanges de philologie romane offerts à Charles Comproux vol. 2 (Montpellier, 1978)

Kingston, R., Bureaucrats and Bourgeois Society: Office Politics and Individual Credit in France, 17891848 (Basingstoke, 2012)

Kirsch, P., Kremnitz, G., and Schlieben-Lange, B., Petite Histoire Sociale de la Langue Occitane: Usages, Images, Littérature, Grammaires et Dictionnaires C. Chabrant (trans.) (Perpignan, 2002)

Kohn, H., 'Napoleon and the Age of Nationalism', Journal of Modern History vol. 21 no.1 (1955) pp.21-37

Laboulais-Lesage, I., Lectures et pratiques de l'espace : L'Itinéraire de Coquebert de Montbret, savant et grand commis d'Etat (1755-1831) (Paris, 1999)

- Reading a Vision of Space: the Geographical Map Collection of Charles-Étienne Coquebert de Montbret (1755-1831)', Imago Mundi vol.56 no.1 (2004) p48-66 
Lacroix J.-B. (ed.), Tresors d'archives, Mille ans d'histoire (Nice, 2005)

Lagrée, M., Religion et cultures en Bretagne 1850-1950 (Paris 1992)

Lamelli A., Lingusitic Atlases, Traditional and Modern', Language and Space : An International Handbook of Linguistic Variation vol.1: Theories and Methods (Berlin, 2010) pp.567-92

Lartichaux, J.Y., 'Linguistic Politics during the French Revolution', Diogènes, vol.97 (1977) pp.65-84

Lauzon, M., Signs of Light: French and British Theories of Linguistic Communication, 1648-1789 (London, 2010)

Le Berre Y. La littérature de langue bretonne : Livres et brochures entre 1790 et 1918 (Brest, 1994)

Le Page R.B. and Tabouret-Keller D., Acts of Identity : Creole Based Approaches to Language and Ethnicity (Cambrdige, 1985)

Le Roy Ladurie, E., Histoire de France des régions: La périphérie française des origines à nos jours (Paris, 2001)

Leerssen, J., 'Literary Historicism: Romanticism, Philologists, and the Presence of the Past', Modern Language Quarterly vol.65 no.2 (June 2004) pp.221-43

- National Thought in Europe: A Cultural History (Amsterdam University Press, Amsterdam, 2006)

Leflon J., Eugène de Mazenod, évêque de Marseille, fondateur des missionaires oblats de Marie immaculée, 1782-1861 (Paris, 1957)

Lehning, J.R. Peasant and French: Cultural contact in rural France during the nineteenth century (Cambridge, 1995)

LePage, R., and Tabouret-Keller, A., Acts of Identity: Creole-based Approaches to Language and Ethnicity (Cambridge, 1985)

Liégois J.-P. , Roms en Europe (Strasbourg, 2007)

Lifschitz, A., Language and Enlightenment: The Berlin Debates of the Eighteenth Century (Oxford, 2012)

Lignereux, A., L'empire des français: 1799-1815 (Paris, 2012)

Lodge, R.A., French from Dialect to Standard (London, 2001)

- 'Le Clivage Oc-Oïl au Moyen âge : Fiction Méthodologique', Mélanges de l'école de Rome : Moye Âge T. 117 no. 2 (2005) pp.595-613

Luti, G., Letteratura e rivoluzioni : saggi su Alfieri, Foscolo, Leopardi (Firenze, 2002) 
Lucy, J., Language Diversity and Thought: A Reformulation of the Linguistic Relativity Hypothesis (Cambridge, 1992)

Lyons, M., Readers and Society in Nineteenth Century France (Basingstoke, 2001)

-Reading Culture and Writing Practices in Nineteenth Century France (London, 2008)

- 'Regionalism and Linguistic conformity in the French Revolution', Forrest, A.I. and Jones, P., (eds.) Reshaping France: Town, Country and Region during the French Revolution (Manchester, 1991) pp.179-92

- 'Fires of Expiation : Book Burnings and Catholic Missions in Restoration France', French History vol.10 no.1 (1996) pp.1-27

Macdonald, S., “'A bheil am feur gorm fhathast?”: Some Problems Concerning Language and Culture Shift', Scottish Studies vol.33 (1999) pp.186-197

- Reimagining Culture: Histories, Identities and the Gaelic Renaissance (Oxford, 1997)

Maciak J., 'Learning to love the Republic: Jacobin propaganda and the peasantry of the HauteGaronne' in European Review of History vol. 6 no. 2 (1999) pp.165-79

Majid, A., Bowerman, M., Kita, S., Haun, D.B.M., and Levinson, S.C., 'Can Language Restructure Cognition? The Case for Space', Trends in Cognitive Sciences vol.8 no.3 (2004) pp.108-14

Margadant, T., Urban Rivalries in the French Revolution (Princeton, 1992)

Martel, P., 'De Coquebert de Montbret à Joanne ; À la découverte du « Midi » ?', D. Fabre and J.-M. Privat (eds.), Savoirs Romantiques : Une naissance de l'ethnographie (Nancy, 2010) pp.165-92

-'La langue (les langues) d’Esmieu', La vie pénible et laborieuse du colporteur Esmieu (Barcelonnette, 2002) pp.186-199

- 'The Troubadours and the French State in D. Van Hulle and J.T. Leersen (eds) Editing the Nation's Memory: Textual Scholarship and Nation-Building in Nineteenth Century Europe (Amsterdam, 2008) p.185-219

McDonald, M., We are not French!: Language, Culture and Identity in Brittany (London, 1989)

McManners J., French Ecclesiastical Society under the Ancien Régime : A Study of Angers in the Eighteenth Century (Manchester, 1960)

- Church and Society in Eighteenth Century France, vol. 1: The Clerical Establishment and its Social Ramifications (Oxford, 1999)

McPhee, P., 'A Case-study of Internal Colonization: The Francisation of Northern Catalonia' in Review, Fernand Braudel Centre for the Study of Economies, Historical Systems and Civilizations vol.3 no.3 (1980) pp.398-428 
- 'Historians, Germans and Culture Brokers: the Circulation of Ideas in the Nineteenth Century French Countryside', Australian Journal of French Studies vol.23 no.3 (1986) pp.115-29

- The Politics of Rural Life: Political Mobilization in the French Countryside, 1846-1852 (Oxford, 1992)

Merle, R., 'Usage politique du provençal, 1814-1840', La question linguistique au Sud au moment de la Révolution Française : actes du colloque de Montpellier, 8-10 Novembre 1984 (Montpellier, 1985) vol.2

- 'Consulat-Empire : un laboratoire de l'aliénation occitane', La question linguistique au sud au moment de la révolution français- LENGAS- Revue de sociolinguistique no.17 (1985) pp.333-408

- 'Du catéchisme en provençal, 1825-51 in M. Lagrée (ed.) Les parlers de la foi, religion et langues régionales (Rennes, 1995) pp.135-40

- Visions de "L'idiome natal » à travers l'enquête impériale sur les patois (1807-1812) : (Langue d'oc, Catalan, Francoprovençal) France, Italie, Suisse (Canet, 2010)

Morpurgo Davies, A., History of Linguistics vol. iv: Nineteenth Century Linguistics (London, 1992)

Muchembled, R., Culture populaire et culture des élites dans la France moderne XVe-XVIIIe siècle (Paris, 1978)

Nandrin, J.-P., 'La Cour de cassation belge de 1832 et le pouvoir judiciaire', in Justice et institutions françaises en Belgique (1795-1815) : Traditions et innovations autour de l'annexion : Actes du colloque tenu à l'université de Lille II, June 1995 (Hellemmes, 1996) pp.275-93

Nordman, D., Frontières de France: De l'espace au territoire, XVIe-XIXe siècle (Paris, 1998)

Nelson W.M., 'Colonizing France: Revolutionary Regeneration and the First French Empire', S. Desan, L. Hunt and W.M. Nelson (eds.) The French Revolution in Global Perspective (London, 2013) pp.73-85

Oakes L., 'Regional Languages, the European Charter and Republican Values in France Today', C. Norrby, J. Hajek (eds.) Uniformity and Diversity in Language Policy: Global Perspectives (Bristol, 2011) pp.68-85

Olive J.L.,'Nomination et dé-nomination de l'autre : des usages ethnonymiques à l'épistémologie discursive en milieu gitan' dans Esprit critique vol.6 no.1 (2004)

Omoniyi, T., 'Hierarchy of Identity', T. Omoniyi and G. White (eds.) The Sociolinguistics of Identity (London, 2006) pp.11-33

Ong, W.J., Orality and Literacy: The Technologizing of the Word (London,1982)

Ozouf, M., L'école de la France: Essais sur la Révolution, l'utopie et l'enseignement (Paris, 1984) - L’homme régénéré: Essais sur la Révolution française (Paris, 1989) 
Ozouf-Marignier, M.V., La formation des départements: la représentation du territoire français à la fin du $18^{e}$ siècle (Paris, 1989)

Ozouf-Marignier, M.V., Nordman, D., Gimeno, R., and Laclau, A. Atlas de la Révolution française vol.4- Le territoire pt 1 Réalités et représentations (Paris, 1989)

Palmer R.R., The Improvement of Humanity: Education and the French Revolution (Guildford, 1985)

Perrot, J.C., L'âge d'or de la statistique régionale (Paris, 1977)

Perrot, J.C, and Woolf, S.J., State and Statistics in France, 1789-1815 (London, 1984)

Peyre H., La Royauté et les langues provinciales (Paris, 1993)

Phillipson, R., Linguistic Imperialism (Oxford, 1992)

Pic, F., 'Essai d'inventaire des textes en Occitan de la Période Révolutionaire', H. Boyer, G. Fourier, P. Gardy, P. Martel, R. Merle and F. Pic. Le Texte Occitan de la Période Révolutionaire (Montpellier, 1989)

Plongeron B., 'Le procès de la fête à la fin de l'Ancien Régime' in B. Plongeron et R. Plannet (eds.) Le christianisme populaire (Paris, 1976)

- Théologie et politique au siècle des lumières, 1770-1820 (Genève, 1973)

Preston D.R., Perceptual Dialectology: Non-Linguists' Views of Areal Linguistics (Philadelphia, 1989)

Revel J., 'Forms of Expertise: Intellectuals and Popular Culture in France, 1650-1800' in S. Kaplan (ed.) Understanding Popular Culture: Europe from the Middle Ages to the Nineteenth Century (New York, 1984) pp.255-74

Robert, A., Bourloton, E., Cougny, G., Dictionnaire des parlementaires français, depuis le 1er mai 1789 jusqu'au 1er mai 1889 (5 vols., Paris, 1889)

Robins R.H. , A Short History of Linguistics (London, 1997)

Rosanvallon, P., L'état en France de 1789 à nos jours (Paris, 1999)

Rosenfeld, S., A Revolution in Language: The Problem of Signs in Late Eighteenth Century France (Stanford, 2001)

Rowe, M., From Reich to State: The Rhineland in the Revolutionary Age, 1780-1830 (Cambridge, 2003)

Rykeboer, H., 'Dutch/Flemish in the North of France', Journal of Multilingual and Multicultural Development vol.23 no.1-2 (2002) pp.22-35

Sahlins, P., Boundaries: The Making of France and Spain in the Pyrenees (Oxford, 1991)

Sala, M., 'Contact and Borrowing', M. Maiden, J.C. Smith, A. Ledgeway (eds.) The Cambridge History of the Romance Languages vol.II: Contexts (Cambridge, 2013) 
Schiffman, H. F., Linguistic Culture and Language Policy (London, 1996)

Schnapper, B., 'Pour une géographie des mentalités judiciaires : La Litiogisité en France au XIXe siècle' in Annales E.S.C. (1979) no. 2 pp.319-419

Schusterman, N., Religion and the Politics of Time: Holidays in France from Louis XIV through Napoleon (Washington, 2010)

— 'Une Loi de l'église et de l'état : Napoleon and the Central Administration of Religious Life' in French History vol.21 no.3 (2007)

Scokpol, T., States and Social Revolutions: A Comparative Analysis of France, Russia and China (Cambridge, 1989)

Scott, J.C., Seeing Like a State: How Certain Schemes to Improve the Human Condition Have Failed (New Haven, 1998)

Sebba M., Wootton T., 'We, They and Identity : Sequential versus identity-related explanation in code-switching', P. Auer (ed.) Code-Switching in Conversation: Language, Interaction and Identity (London, 1998)

Sepinwall, A.G., The Abbé Grégoire and the French Revolution, the Making of Modern Universalism (London, 2005)

Serna P., 'Tout révolution est guerre d'indépendance', J.-L. Chappey, B. Gainot, G. Mazeau, F. Régent, and P. Serna (eds) Pour quoi faire la Révolution (Marseille, 2012)

Shapiro F.R., 'On the Origin of the Term Indo-Germanic', Historiographia Linguistica vol.8 no.1 (1981) pp.165-70

Sibille J., 'La notion de langues de France, son contenu et ses limites', in G. Kremnitz (ed.) Histoire sociale des langues de France (Rennes, 2013)

Silva, K., 'Immigration, Occupation and the Boundaries of Limousin Solidarity in Nineteenth Century Paris', French Historical Studies vol.35 no.1 (2012) pp.61-92

Simoni-Aurembou, M.-R., 'La Couverture Géolinguistique de l'Empire Français: L'Enuete de la Parabole de l'Enfant Prodigue', Espaces Romans, Etudes de dialectologie et de géolinguistique offertes à Gaston Tuaillon (Grenoble 1989) vol.2 pp.114-132

Singer, B., Village Notables in Nineteenth-Century France: Priests, Mayors, Schoolmasters (New York, 1983)

Soboul, A., Les sans-culottes parisiens en l'an II (Paris, 1958)

Steinmetz, G., 'Culture and the State', in G Steinmetz (ed.) State/Culture: State-Formation after the Cultural Turn (London, 1999) pp.1-51

Sterne, J., 'The Theology of Sound: A Critique of Orality', in Canadian Journal of Communication vol.36 (2011) pp.207-25 
Storost, J., Langue française- langue universelle ? Die Diskussion über die Universalität des Französischen and der Berliner Akademie der Wissenschaften (Hamburg, 2008)

Tackett T., Priest and Parish in Eighteenth Century France (Princeton, 1977) pp.83-4, p.159

-Revolution and Regional Culture in France: The Ecclesiastical Oath of 1791 (Princeton, 1986)

Tassoni G., Arti e tradizioni popolari: Le inchieste napoleoniche sui costumi e le tradizioni nel regno italico (Bellinzona, 1973)

Thiesse, A.M., La création des identités nationales, Europe, XVIIIe-XXe siècle (Paris, 1999)

Trask R., A History of Basque (London, 1997)

Trenard, L., 'L'enseignement de la langue nationale: une réforme pédagogique, 1750-1790', in Historical Reflections/Réflexions Historiques vol.7 no.2/3 (1980) pp.95-114

Trepos P., 'Le Catholicon de Jehan Lagadeuc, pour son cinquième centenaire' Annales de Bretagne Vol. 71 no. 4 (1964) pp.501-52

Trudeau D., 'L'ordonnance de Villers-Cotterêts et la langue française : Histoire ou interprétation' in Bibliothèque d'humanisme et renaissance vol. 45 no. 3 (1983) pp.461-72

Trudgill, P., Sociolinguistics: An Introduction to Language and Society (London, 2000)

Tudesq, A., Les grandes notables en France, 1840-1849 : Étude historique d'une psychologie sociale (2 vols., Paris, 1964)

Vanhecke, E., and Groof, J. de, 'New Data on Language Policy and Language Choice in $19^{\text {th }}$ Century Flemish City Administrations', in S. Elspaß, N. Langer, J. Scharloth, W. Vanderbussche (eds) Germanic Language Histories from Below, 1700-2000 (Berlin, 2007) pp.449-69

Veltman, C., 'Theory and Method in the Study of Language Shift', in J.R. Dow (ed.) Language and Ethnicity (Amsterdam, 1991)

Vento, C. del 'La première fortune d'Alfieri en France : de la traduction française du « Panégyrique de Trajan par Pline " (1787) à la traduction des " oeuvres dramatiques " (1802)', in Revue des études italiennes vol.50 no.1/2 (2004) pp.215-228

Vovelle, M., Piété baroque et déchristianisation en Provence au XVIIle siècle (Paris, 1978)

Walter H., Fawcett P. (trans.), French Inside Out : The Worldwide Development of the French Language in the Past, Present and Future (London, 1994)

Weber, E., Peasants into Frenchmen: The Modernization of Rural France, 1870-1914 (Stanford, 1976)

White P. , 'Geographical Aspects of Minority Language Situations in Italy', in C.H. Williams (ed.) Linguistic Minorities, Society, and Territory (Clevedon, 1991) 
Whorf, B.L., Language, Thought and Reality: Selected Writings of Benjamin Lee Whorf (Cambridge Mass., 1956)

Woloch, W., The New Regime: Transformations of the French Civic Order, 1789-1820s (New York, 1994)

Woolard, K.A., 'Language Variation and Cultural Hegemony: Toward and Integration of Sociolinguistic and Social Theory', American Ethnologist vol.12 no.4 (1985) pp.738-748

Woolf, S., 'French Civilization and Ethnicity in the Napoleonic Empire', Past and Present no.224 (1989) pp.96-120

- Napoleon's Integration of Europe (London, 1991)

- 'The Construction of a European World-View in the Revolutionary-Napoleonic Years', Past and Present no.137 (1992) pp.72-101

Wright, J., The Regionalist Movement in France: Jean-Charles Brun and French Political Thought (Oxford, 2003)

Wright S., 'Fixing National Borders: Language and Loyalty in Nice' in P. Gubbins and M. Holt (eds.), in Beyond Boundaries: Language and Identity in Contemporary Europe (Clevedon, 2002) pp.91-100

Zantedeschi F., Une langue en quête d'une nation: Le débat sur la langue d'oc au XIXe siècle, unpublished PhD thesis, European University Institute, (2009) 